\title{
NBSIR 74.460 \\ Comparison of Power Output and Exhaust Pollutants of Two Postal Service Vehicles Operated on Three Hydrocarbon Fuels
}

\author{
J. E. Hill and D. A. Didion
}

Center for Building Technology Institute for Applied Technology

National Bureau of Standards

Washington, D. C. 20234

September 21, 1973

Prepared for

U. S. Postal Service

Bureau of Research and Engineering

Washington, D. C. 20260 

NBSIR 74-460

\section{COMPARISON OF POWER OUTPUT AND EXHAUST}

POLLUTANTS OF TWO POSTAL SERVICE VEHICLES

OPERATED ON THREE HYDROCARBON FUELS

J. E. Hill and D. A. Didion

Center for Building Technology

Institute for Applied Technology

National Bureau of Standards

Washington, D.C. 20234

September 21, 1973

Prepared for

U. S. Postal Service

Bureau of Research and Engineering

Washington, D. C. 20260

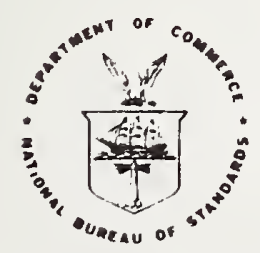

U. S. DEPARTMENT OF COMMERCE, Froderick B. Dent, Secretary NATIONAL BUREAU OF STANDARDS, Richard W. Roberts, Director 
Comparison of Power Output and Exhaust Pollutants of Two Postal Service Vehicles

Operated on Three Hydrocarbon Fuels

\author{
J. E. Hill and D. A. Didion \\ Center for Building Technology \\ Institute for Applied Technology \\ National Bureau of Standards \\ Washington, D. C. 20234
}

\begin{abstract}
One possible solution for the reduction of pollutants
\end{abstract} from internal combustion engines is the use of gaseous fuels such as natural gas or propane. The best application for the use of these fuels appears to be with fleet operators. The federal government operates between 300,000 and 400,000 vehicles which makes it an excellent candidate for using them. This paper describes a laboratory investigation in which the power output and pollutant levels of two Postal Service vehicles equipped with dual-fuel systems, were determined at simulated road conditions in an environmental chamber at temperatures from $0{ }^{\circ} \mathrm{F}$ to $110^{\circ} \mathrm{F}$.

Key Words: Air pollution; compressed natural gas engine; dual fuel vehicles; propane engine; vehicle emissions 


\section{LIST OF FIGURES}

Figure $11 / 2$ Ton Truck Inside the Environmental Chamber

Figure 2 Compressed Natural Gas System Schematic

Figure 3 Air-Mixer and Associated Natural Gas Fuel System for the $1 / 2$ Ton Truck

Figure 4 Measurement of Rate of Fuel Usage for Propane Tests

Figure 5 Carburetor Adjustment for Propane Tests

Figure 61 Ton Truck Inside the Environmental Chamber

Figure 76 Cylinder Engine Equipped with Venturi-Insert Natural Gas Fuel system

Figure 8 Chassis Dynamometer

Figure 9 Engine Throttle Position and Dynamometer Adjustments Being Made from tine Instrumentation Room

Figure 10 Vehicle and Environmental Parameters Measured During a Vehicle Test

Figure 11 Exhaust Probe Being Placed in Position

Figure 12 Basic Adjustments Being Made for the Measurement of. NO ${ }_{x}$ Content of the Exhaust Gas

Figure 13 Schematic Representation of Gas Restrictor for the $1 / 2$ Ton Truck Using Propane

Figure $141 / 2$ Ton Truck During Cold Start Tests

Figure 15 Nitrogen Oxides Versus Spark Advance for a $1 / 2$ Ton Truck Using Gasoline

Figure 16 Nitrogen Oxides Versus Spark Advance for a $1 / 2$ Ton Truck Using Gasoline

Figure 17 Nitrogen Oxides Versus Spark Advance for a $1 / 2$ Ton Truck Using Gasoline

Figure 18 Hydrocarbons Versus Spark Advance for a $1 / 2$ Ton Truck Using Gasoline

Figure 19 Hydrocarbons Versus Spark Advance for a $1 / 2$ Ton Truck Using Gasoline 
Figure 20 Hydrocarbons Versus Spark Advance for a 1/2 Ton Truck Using Gasoline

Figure 21 Carbon Monoxide Versus Spark Advance for a 1/2 Ton Truck Using Gasoline

Figure 22 Carbon Monoxide Versus Spark Advance for a 1/2 Ton Truck Using Gasoline

Figure 23 Carbon Monoxide Versus Spark Advance for a $1 / 2$ Ton Truck Using Gasoline

Figure 24 Nitrogen Oxides Versus Spark Advance for a $1 / 2$ Ton Truck Using CNG

Figure 25 Hydrocarbons and Carbon Monoxide Versus Spark Advance for a $1 / 2$ Ton Truck using CNG

Figure 26 Hydrocarbons and Carbon Monoxide Versus Spark Advance for a $1 / 2$ Ton Truck Using CNG

Figure 27 Air-Fuel Ratio Versus Spark Advance for a $1 / 2$ Ton Truck Using CNG

Figure 28 Gas Pressure at Running Conditions Versus Spark Advance for a $1 / 2$ Ton Truck Using CNG

Figure 28 Nitrogen Oxides Versus Spark Advance for a $1 / 2$ Ton Truck Using CNG

Figure 30 Hydrocarbons and Carbon Monoxide Versus Spark Advance for a $1 / 2$ Ton Truck Using CNG

Figure 31 Hydrocarbons and Carbon Monoxide Versus Spark Advance for a $1 / 2$ Ton Truck Using CNG

Figure 32 Air-Fuel Ratio Versus Spark Advance for a $1 / 2$ Ton Truck Using CNG

Figure 33 Gas Pressure at Running Conditions Versus Spark Advance for a $1 / 2$ Ton Truck Using CNG

Figure 34 Nitrogen oxides Versus Air-Fuel Ratio for a $1 / 2$ Ton Truck Using CNG

Figure 35 Hydrocarbons and Carbon Monoxide Versus Air-Fue 1 Ratio for a $1 / 2$ Ton Truck Using CNG

Figure 36 Nitrogen Oxides Versus Air-Fuel Ratio for a $1 / 2$ Ton Truck Using CNG

Figure 37 Hydrocarbons and Carbon Monoxide Versus Air-Fuel Ratio for a $1 / 2$ Ton Truck Using CNG 
Figure 38 Maximum Horsepower and Nitrogen Oxides Versus AirFue 1 Ratio for a $1 / 2$ Ton Truck Using CNG and operating at Full Throttle

Figure 39 Hydrocarbons and Carbon Monoxide Versus Air-Fue 1 Ratio for a $1 / 2$ Ton Truck Using CNG and Operating at Full Throttle

Figure 40 Idle Gas Pressure Versus Air-Fuel Ratio for a $1 / 2$ Ton Truck Using CNG

Figure 41 Gas Pressure at Running Conditions Versus Idle Gas Pressure for a $1 / 2$ Ton Truck Using CNG

Figure 42 Nitrogen Oxides Versus Air-Fuel Ratio for a $1 / 2$ Ton Truck Using CNG

Figure 43 Hydrocarbons Versus Air-Fuel Ratio for a $1 / 2$ Ton Truck Using CNG

Figure 44 Carbon Monoxide Versus Air-Fue1 Ratio for a $1 / 2$ Ton Truck Using CNG

Figure 45 Gas Pressure at Running Conditions Versus Air-Fuel Ratio for a $1 / 2$ Ton Truck Using CNG

Figure 46 Nitrogen Oxides Versus Air-Fuel Ratio for a $1 / 2$ Ton Truck Using CNG

Figure 47 Hydrocarbons and Carbon Monoxide Versus Air-Fue 1 Ratio for a $1 / 2$ Ton Truck Using CNG

Figure 48 Nitrogen Oxides Versus Air-Fuel Ratio for a $1 / 2$ Ton Truck Using CNG

Figure 49 Hydrocarbons and Carbon Monoxide Versus Air-Fuel Ratio for a $1 / 2$ Ton Truck Using CNG

Figure 50 Maximum Horsepower and Pollutants Versus Air-Fuel Ratio for a $1 / 2$ Ton Truck Using CNG and operating at Full Throttle

Figure 51 Gas Pressure at Runing Conditions Versus Air-Fuel Ratio for a $1 / 2$ Ton Truck Using CNG

Figure 52 Nitrogen Oxides Versus Air-Fuel Ratio for a $1 / 2$ Ton Truck using CNG

Figure 53 Hydrocarbons and Carbon Monoxide Versus Air-Fue 1 Ratio for a $1 / 2$ Ton Truck Using CNG

Figure 54 Nitrogen Oxides Versus Spark Advance for a $1 / 2$ Ton Truck Using LPG 
Figure 55 Hydrocarbons Versus Spark Advance for a $1 / 2$ Ton Truck Using LPG

Figure 56 Carbon Monoxide Versus Spark Advance for a $1 / 2$ Ton Truck Using LPG

Figure 57 Nitrogen Oxides Versus Spark Advance for a $1 / 2$ Ton T'ruck Using LPG

Figure 58 Hydrocarbons Versus Spark Advance for a $1 / 2$ Ton Truck Using LPG

Figure 59 Carbon Monoxide Versus Spark Advance for a 1/2 Ton Truck Using LPG

Figure 60 Nitrogen Oxides Versus Spark Advance for a $1 / 2$ Ton Truck Using LPG

Figure 61 Hydrocarbons Versus Spark Advance for a $1 / 2$ Ton Truck Using LPG

Figure 62 Carbon Monoxide Versus Spark Advance for a, 1/2 Ton Truck Using LPG.

Figure 63 Air-Fuel Ratio Versus Spark Advance for a $1 / 2$ Ton Truck Using LPG

Figure 64 Air-Fue1 Ratio Versus Spark Advance for a $1 / 2$ Ton Truck Using LPG

Figure 65 Nitrogen Oxides Versus Air-Fuel Ratio for a $1 / 2$ Ton Truck Using LPG

Figure 66 Hydrocarbons Versus Air-Fuel Ratio for a $1 / 2$ Ton Truck Using LPG

Figure 67 Carbon Monoxide Versus Air-Fue1 Ratio for a $1 / 2$ Ton Truck Using LPG

Figure 68 Nitrogen oxides Versus Air-Fue1 Ratio for a $1 / 2$ Ton Truck Using LPG

Figure 69 Hydrocarbons Versus Air-Fuel Ratio for a $1 / 2$ Ton Truck Using LPG

Figure 70 Carbon Monoxide Versus Air-Fuel Ratio for a $1 / 2$ Ton Truck Using LPG

Figure 71 Nitrogen Oxides Versus Air-Fuel Ratio for a $1 / 2$ Ton Truck Using LPG

Figure 72 Hydrocarbons Versus Air-Fuel Ratio for a $1 / 2$ Ton Truck Using LPG 
Figure 73 Carbon Monoxide Versus Air-Fuel Ratio for a $1 / 2$ Ton Truck Using LPG

Figure 74 Nitrogen Oxides Versus Air-Fuel Ratio for a $1 / 2$ Ton Truck Using LPG

Figure 75 Hydrocarbons Versus Air-Fuel Ratio for a $1 / 2$ Ton Truck Using LPG

Figure 76 Carbon Monoxide Versus Air-Fuel Ratio for a $1 / 2$ Ton Truck Using LPG

Figure 77 Air-Fuel Ratio Versus Power Valve Setting for a $1 / 2$ Ton Truck Using LPG

Figure 78 Nitrogen Oxides Versus Normalized Air-Fuel Ratio for a $1 / 2$ Ton Truck Using CNG and LPG

Figure 79 Hydrocarbons Versus Normalized Air-Fuel Ratio for a $1 / 2$ Ton Truck Using $C N G$ and LPG

Figure 80 Carbon Monxoide Versus Normalized Air-Fuel Ratio for a $1 / 2$ Ton Truck Using $C N G$ and $L P G$

Figure 81 Nitrogen Oxides Versus Normalized Air-Fuel Ratio for a $1 / 2$ Ton Truck Using $C N G$ and LPG

Figure 82 Hydrocarbons Versus Normalized Air-Fuel Ratio for a 1/2 Ton Truck Using CNG and LPG

Figure 83 Carbon Monoxide Versus Normalized Air-Fuel Ratio for a $1 / 2$ Ton Truck Using CNG and LPG

Figure 84 Nitrogen Oxides Versus Normalized Air-Fuel Ratio for a $1 / 2$ Ton Truck Using CNG and LPG

Figure 85 Hydrocarbons Versus Normalized Air-Fuel Ratio for a $1 / 2$ Ton Truck Using CNG and LPG

Figure 86 Carbon Monoxide Versus Normalized Air-Fuel Ratio for a $1 / 2$ Ton Truck Using CNG and LPG

Figure 87 Nitrogen Oxides Versus Spark Advance for a $1 / 2$ Ton Truck Using Gasoline, CNG and LPG

Figure 88 Hydrocarbons Versus Spark Advance for a $1 / 2$ Ton Truck Using Gasoline, CNG and LPG

Figure 89 Carbon Monoxide Versus Spark Advance for a $1 / 2$ Ton Truck Using Gasoline, CNG and LPG

Figure 90 Nitrogen Oxides Versus Spark Advance for a $1 / 2$ Ton Truck Using Gasoline, $C N G$ and LPG 
Figure 91 Hydrocarbons Versus Spark Advance for a $1 / 2$ Ton Truck Using Gasoline, CNG and LPG

Figure 92 Carbon Monoxide Versus' Spark Advance for a $1 / 2$ Ton Truck Using Gasoline, CNG and LPG

Figure 93 Nitrogen Oxides Versus Spark Advance for a $1 / 2$ Ton Truck Using Gasoline, and LPG

Figure 94 Hydrocarbons Versus Spark Advance for a $1 / 2$ Ton Truck Using Gasoline, and LPG

Figure 95 Carbon Monoxide Versus Spark Advance for a $1 / 2$ Ton Truck Using Gasoline, and LPG

Figure 96 Nitrogen Oxides Versus Spark Advance for a 1 Ton Truck Using Gasoline

Figure 97 Nitrogen Oxides Versus Spark Advance for a 1 Ton Truck Using Gasoline

Figure 98 Nitrogen Oxides Versus Spark Advance for a 1 Ton Truck Using Gasoline

Figure 99 Hydrocarbons Versus Spark Advance for a 1 Ton Truck Using Gasoline

Figure 100 Hydrocarbons Versus Spark Advance for a 1 Ton Truck Using Gasoline

Figure 101 Hydrocarbons Versus Spark Advance for a 1 Ton Truck Using Gasoline

Figure 102 Carbon Monoxide Versus Spark Advance for a 1 Ton Truck Using Gasoline

Figure 103 Carbon Monoxide Versus Spark Advance for a 1 Ton Truck Using Gasoline

Figure 104 Carbon Monoxide Versus Spark Advance for a 1 Ton Truck Using Gasoline

Figure 105 Carbon Monoxide Versus Spark Advance for a 1 Ton Truck Using Gasoline

Figure 106 Pollutants Versus Spark Advance for a 1 Ton Truck Using CNG

Figure 107 Air-Fuel Ratio Versus Spark Advance for a 1 Ton Truck Using CNG 
Figure 108 Pollutants Versus Spark Advance for a 1 Ton Truck Using CNG

Figure 109 Pollutants Versus Spark Advance for a 1 Ton Truck Using CNG

Figure 110 Pollutants Versus Spark Advance for a 1 Ton Truck Using CNG

Figure 111 Nitrogen Oxides Versus Spark Advance for a 1 Ton Truck Using CNG

Figure 112 Hydrocarbons Versus Spark Advance for a 1 Ton Truck Using CNG

Figure 113 Carbon Monoxide Versus Spark Advance for a 1 Ton Truck Using CNG

Figure 114 Air-Fuel Ratio and Power Valve Setting Versus Spark Advance for a 1 Ton Truck Using CNG

Figure 115 Nitrogen Oxides Versus Spark Advance for a 1 Ton Truck Using CNG

Figure 116 Hydrocarbons Versus Spark Advance for a 1 Ton Truck Using CNG

Figure 117 Carbon Monoxide Versus Spark Advance for a 1 Ton Truck Using CNG

Figure 118 Air-Fuel Ratio and Power Valve Setting Versus Spark Advance for a 1 Ton Truck Using CNG

Figure 119 Nitrogen Oxides Versus Spark Advance for a 1 Ton Truck Using CNG

Figure 120 Hydrocarbons Versus Spark Advance for a 1 Ton Truck Using CNG

Figure 121 Carbon Monoxide Versus Spark Advance for a 1 Ton Truck Using CNG

Figure 122 Air-Fuel Ratio and Power Valve Setting Versus Spark Advance for a 1 Ton Truck Using CNG

Figure 123 Maximum Horsepower and Nitrogen Oxides Versus AirFue 1 Ratio for a 1 Ton Truck Using CNG and operating at Full Throttie

Figure 124 Maximum Horsepower and Hydrocarbons Versus Air-Fue 1 Ratio for a 1 Ton Truck Using CNG and Operating at Ful1 Throttle 
Figure 125 Maximum Horsepower and Carbon Monoxide Versus AirFue 1 Ratio for a 1 Ton Truck Using CNG and Operating at Full Throttle

Figure 126 Power Valve Setting Versus Air-Fuel Ratio for a 1 Ton Truck Using CNG and Operating at Full Throttle

Figure 127 Maximum Horsepower and Nitrogen Oxides Versus Air-Fuel Ratio for a 1 Ton Truck Using CNG and Operating at Full Throttle

Figure 128 Maximum Horsepower and Hydrocarbons Versus AirFue 1 Ratio for a 1 Ton Truck Using CNG and Operating at Full Throttle

Figure 129 Maximum Horsepower and Carbon Monoxide Versus AirFue 1 Ratio for a 1 Ton Truck Using CNG and Operating at Full Throttle

Figure 130 Power Valve Setting Versus Air-Fuel Ratio for a 1 Ton Truck Using CNG and Operating at Full Throttle 


\section{LIST OF TABLES}

Table 1 Characteristics of the PALCo system operation Table 2 General Comparison of Emissions 
1. Introduction . . . . . . . . . . . . . . . . . . 1

2. Description of Vehicles and Fuel systems . . . . . 8

$2.11 / 2$ Ton Truck . . . . . . . . . . . . 8

2.21 Ton Truck . . . . . . . . . . . . . . 15

3. Test Apparatus and Procedure . . . . . . . . . . 18

4. Results and Discussion - $1 / 2$ Ton Truck . . . . . . 34

4.1 Gasoline-Fueled Tests . . . . . . . . . . . 34

4.2 Compressed Natural Gas-Fueled Tests . . . . . 45

4.2.1 Spark Advance as the Independent Variable... . . . . . . . 45

4.2.2 Air-Fuel Ratio as the Independent Variable... . . . . . . . . 51

4.3 Propane-Fueled Tests . . . . . . . . . . . 77

4.3.1 Spark Advance as the Independent Variable... . . . . . . . . . . 77

4.3.2 Air-Fuel Ratio as the Independent Variable... . . . . . . . . 95

4.4 Comparison of the Fuels . . . . . . . . . . 110

4.5 Cold-Start Tests . . . . . . . . . . 130

4.5.1 Compressed Natural Gas and Gasoline-
Fueled Tests . . . . . . . . . . . 130

4.5.2 Propane and Gasoline-Fueled Tests. . . 132

5. Results and Discussion - 1 Ton Truck . . . . . . . 133

5.1 Gasoline-Fueled Tests . . . . . . . . . . 133

5.2 Compressed Natural Gas-Fueled Tests . . . . . . 144

5.2.1 Spark Advance as the Independent Variable... . . . . . . . . . 144 
5.2.2 Air-Fue1 Ratio as the Independent Variable... . . . . . . . . 164

5.3 Cold-Start Tests . . . . . . . . . 170

6. Conclusions. . . . . . . . . . . . . . . . . . . 176

7. References . . . . . . . . . . . . . . . . . 181

8. Acknowledgements . . . . . . . . . . . . . . . 182 


\section{Introduction}

The concern on a national scale for the quality of the environment and in particular the nation's air, led to the establishment of the Clean Air Act of 1970. This act and its amendments require that strict standards of emission control on automotive engines be met by 1976. This relatively early date practically guarantees that the standards be met by a conventional internal combustion engine rather than by a new approach to automotive power. Consequently, vigorous attention is being given to possible solutions that involve modifications to the engine as well as the fuel it burns.

The primary pollutants of internal combustion engines are carbon monoxide ( $C O$ ) and hydrocarbons (HC) and the oxides of nitrogen $\left(\mathrm{NO}_{\mathrm{x}}\right)$. They are formed during the combustion process as follows (1)*:

"Hydrocarbons. After the spark plug ignites the fuelair mixture inside the cylinder, the flame spreads outward until it nears the cylinder wall. There the mixture is too cool to burn and the flame is "quenched." The partially burned gasoline vapor which remains forms layers of hydrocarbons on the cylinder head and walls. The deposits on the head blow out of the engine early in the exhaust stroke. Those on the walls leave later as as the piston scrapes them off.

\footnotetext{
*The numbers refer to references at the end of this report.
} 
Carbon Monoxide. When fuel in the cylinder is completely burned, it leaves the engine as harmless carbon dioxide. But partially burned fuel finishes only part of the chemical transformation to carbon dioxide -- the result being carbon monoxide. Carbon monoxide forms both in the expansion and exhaust strokes, especially when the ratio of fuel to air is high. Because engines need fuel-rich mixtures to run smoothly, engineers cannot easily eliminate carbon monoxide emissions.

Nitric Oxide. Nitric oxide forms in the engine when nitrogen and oxygen combine at high temperatures early in the expansion stroke. The higher the temperature and the more oxygen available, the more nitric oxide is formed. Thus nitric oxide forms under optimal conditions that are opposite to those under which most hydrocarbons and carbon monoxide form: relatively more air yields nitric oxide, more fuel yields hydrocarbons and carbon monoxide."

Reference (2) specifies the testing procedure and accompanying driving cycle (CVS-3) that are to be employed in the certification of the 1975 and 1976 vehiclest to determine whether their mass emissions are below the following levels:

$$
\mathrm{HC} \quad \mathrm{CO} \quad \mathrm{NO}_{\mathrm{x}}
$$
$19750.41 \mathrm{~g} / \mathrm{mi}$
$3.4 \mathrm{~g} / \mathrm{mi}$
$3.0 \mathrm{~g} / \mathrm{mi}$
$1976 \quad 0.41 \mathrm{~g} / \mathrm{mi}$
$3.4 \mathrm{~g} / \mathrm{mi}$
$0.4 \mathrm{~g} / \mathrm{mi}$

*This is prior to the 1 year delay recently authorized by the Director of the Environmental Protection Agency. 
There are many engine modifications being proposed to reduce the quantity of these pollutants to acceptable levels. These include exhaust gas recirculation to alter the air-fuel ratio and reduce peak cycle temperature and the use of secondary combustion processes (thermal reactors). The Environmental Protection Agency recently released test results showing that prototype vehicles equipped with the Mazda* rotary engine produced by Toyo Kogyo of Japan have met the 1975 standards listed above; however, the nitrogen oxide emissions were more than double those permitted under the 1976 standard. Japan's Honda Motor Company* recently announced that they will be producing a four-seat passenger car that will meet the 1975 standard. It will be the first production-line car with the more drastic modification of the "stratified-charge" engine (3). A mixture of fuel that would ordinarily be too lean to ignite in the cylinder is coaxed into burning by the ignition of an adjoining layer of much richer fuel. To accomplish this stratification of fuel, a small combustion chamber with its own spark plug and valve is added at the top of each cylinder to accomodate the richer mixture.

Modification of the basic gasoline fuel is not considered to have major potential for reducing the pollutants. However, the use of an entirely different fuel does seem feasible for some applications. One such fuel is hydrogen and recent

*Use of a trade name neither constitutes or implies endorsement by the National Bureau of Standards. 
experiments have been very interesting. Dr. Roger Schoeppel of Oklahoma State University has modified a conventional internal combustion engine for direct injection of gaseous hydrogen into the cylinder, similar to the fuel-injection process in a standard diesel engine. Nitrogen oxides were found to be the only pollutant and those were at levels ten times lower than of a gasoline engine. Similarly, Dr. Robert Adt and a graduate student of the University of Miami modified a standard 1971 Toyota station wagon to burn compressed gaseous hydrogen. They found that at an average cruising speed of $40 \mathrm{mph}$ the $\mathrm{NO}_{x}$ pollutant (only one emitted) was only $18 \mathrm{ppm}$, a tiny fraction of the $984 \mathrm{ppm}(3.1 \mathrm{~g} / \mathrm{mi})$ of the 1975 standard. However, hydrogen as a fuel has to be considered only in terms of a long term solution due to problems yet to be solved involving storage, safety, and production. For example, a normal 20-gallon tankful of gasoline weighs about 120 pounds. To store the equivalent amount of energy in the form of hydrogen gas would require a container holding 66 cubic feet and weighing a ton. To store it as a supercold liquid would require a tank of 353 pounds and 10.2 cubic feet, four times the size of a normal gas tank. It therefore appears that the future large-scale uses for hydrogen as a fuel will logically be in airplanes, 1 ong-haul trucks, and city buses.

Other gaseous fuels that have potential for immediate use (barring problems associated with supply) are compressed natural gas (CNG) and liquid petroleum gas (LPG) or propane. 
There has been considerable experience in the last several years in converting conventional vehicles to burn these gaseous Euels and significant reductions in hydrocarbons and carbon monoxide have been noted along with some reduction in nitrogen oxides. The problems of storage and carburetion have been satisfactorily solved so that the total cost of vehicle conversion is about $\$ 300$. The pollutant reductions occur as a result of cleaner burning in the engine.

With gasoline, the fuel must first be vaporized and then mixed with the correct amount of air. In gaseous fuel systems, the carburetor only needs to mix in the proper amount of air. This makes the carburetor much simpler and more accurate. Mixing is much more thorough and hopefully no cylinder to cylinder variations exist. In addition, there is no liquid in the induction system to upset the mixture or pass through the engine unburned. It is this high degree of carburetion control and the simple chemical composition of gaseous fuels that makes the operation of gaseous fuel systems clean. An additional advantage to the use of these fuels include the fact that no tetraethyl lead or additives need to be added due to the fuels' inherent high octane rating compared with gasoline (i.e., CNG has a rating of 130 compared to 100 for premium gasoline) and the associated reduced maintenance expenses.

The subject of reactivity has been mentioned frequently by proponents of the gasified fuels. Photochemical smog is formed by the reaction of hydrocarbons with nitric oxides in 
the presence of sunlight (4). However, not all hydrocarbons are really reactive. Their reactivity depends upon their structure. They all fall into general classifications such as saturates (paraffins and naphthelenes), aromatics, and olefins. The saturates have generally a low reactivity. The aromatics occupy a middle gound and as a group, the olefin compounds have very high reactivity (5). Consequently a comparison between the hydrocarbon level of exhaust gases of CNG or LPG and gasoline, as done in this study and many others, does not necessarily give a true evaluation of the effect the fuel usage has on the resultant smog. LPG for example is generally composed of over $90 \%$ paraffins whereas gasoline contains 17 to $22 \%$ olefins and 20 to $25 \%$ aromatic hydrocarbons (6). As with any new system, there are some disadvantages. 'l'oday's vehicles must be converted in order to burn gaseous fuels and the fuels, especially natural gas, are not readily available in service stations. Therefore special provisions must be made to obtain and store the fuel. These factors restrict shops and mechanics who can be trained to convert the vehicles and maintain them. Most mechanics are not familiar with gaseous fuel carburetors. Also, many fleet operators buy their fuel in bulk and have their own refueling facilities. This practice requires special equipment to store and handle a gaseous fue 1 .

The Federal Government operates between 300,000 and 400,000 vehicles--an excellent candidate for using gaseous fuels. 
Consequently, the General Services Administration launched in October of 1969 , the Federal Government's first fleet of CNG powered test vehicles. At that time twelve vehicles in the Los Angeles area were converted to a dual-fuel system (with the ability to burn either gasoline or natural gas). Today approximate1y 1500 GSA vehicles operate with such a system. In addition, the Postal Service has operated a fleet of approximately 50 vehicles in the same manner and is presently considering expanding their operation.

The purpose of this report is to describe comprehensive tests that were conducted on two Postal Service vehicles, a $1 / 2$ ton truck and a 1 ton truck, to determine performance characteristics, especially when the trucks were operated at ambient temperatures of approximately $0^{\circ} \mathrm{F}$ and $100^{\circ} \mathrm{F}$. The tests consisted of determining the emission and mechanical performance characteristics of the vehicles when operated at various simulated loads and speeds from idling to 50 miles per hour. Testing conditions covered a span of environmental temperatures and gasoline, compressed natural gas and propane were used as fuel. A variety of different engine settings (air-fuel ratio and spark advance) was included. 
2. Description of Vehicles and Fuel systems

$2.11 / 2$ Ton Truck

The $1 / 2$ ton truck is shown in Figure 1 as it was tested in an NBS environmenta 1 chamber. This truck was powered by a 232 cubic inch, 6 cylinder engine. For the first series of tests, the truck was equipped with a natural gas conversion kit so that the vehicle could be run on both gasoline and compressed natural gas. A schematic diagram of the natural gas system is shown in Figure 2. The system used two stages of pressure regulation (Item 3 and 8 in Figure 2). A solenoid valve prevented fuel from entering the low pressure (second stage, Item 8) regulator when the engine was not operating. Located on the regulator assembly (Item 5) was the connection for the pressure gauge which served as a fuel level indicator on the dashboard (Item 19). A one-way valve and quick disconnect fitting (Item 5) were provided for fueling. The heart of the system was the gas-air mixer (Item 12) which replaced the normal air cleaner on top of the carburetor and made possible use of either natural gas or gasoline interchangeably. The air-mixer, second stage regulator, and associated equipment can be seen in Figure 3 installed on the vehicle. 


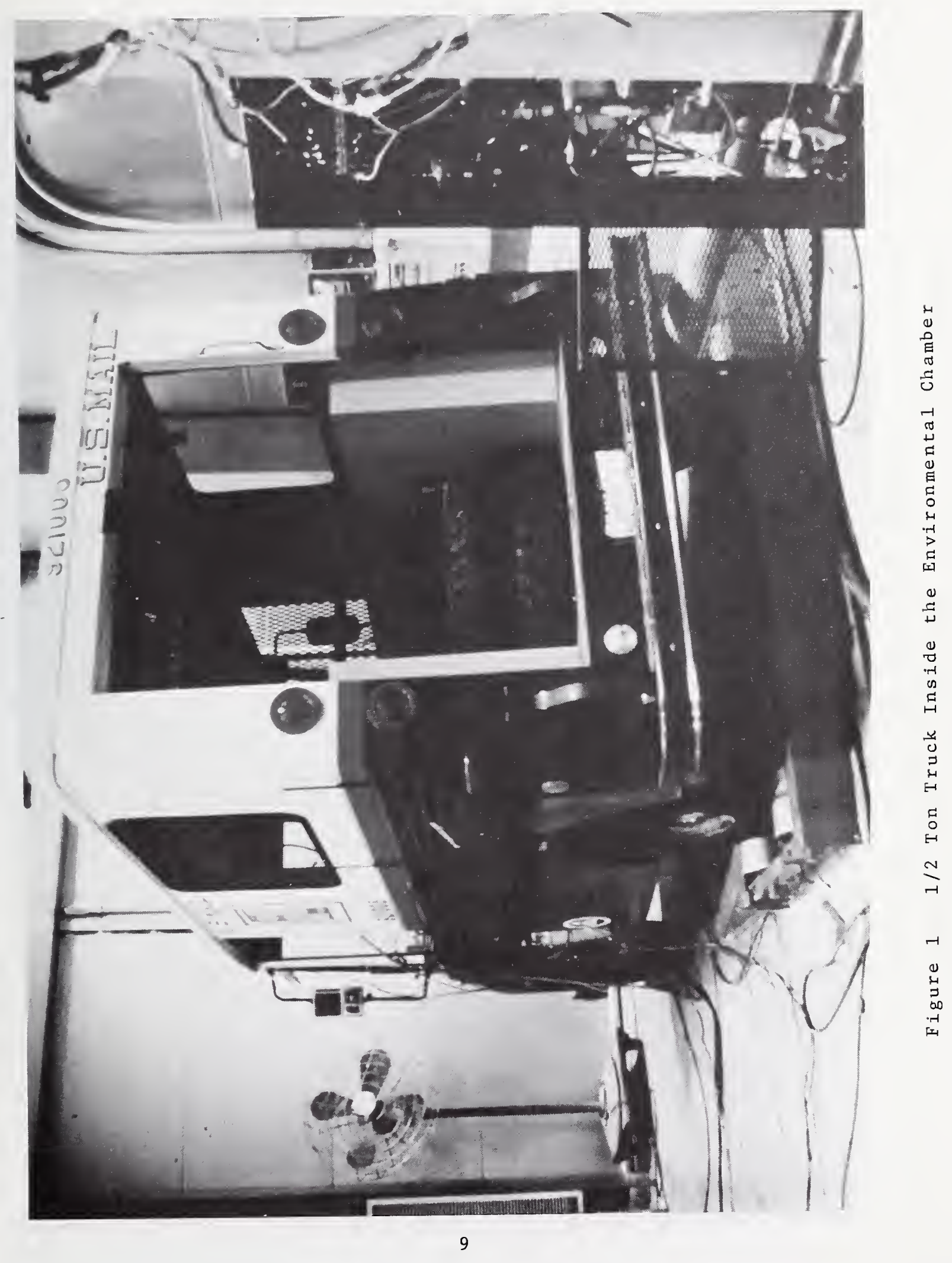




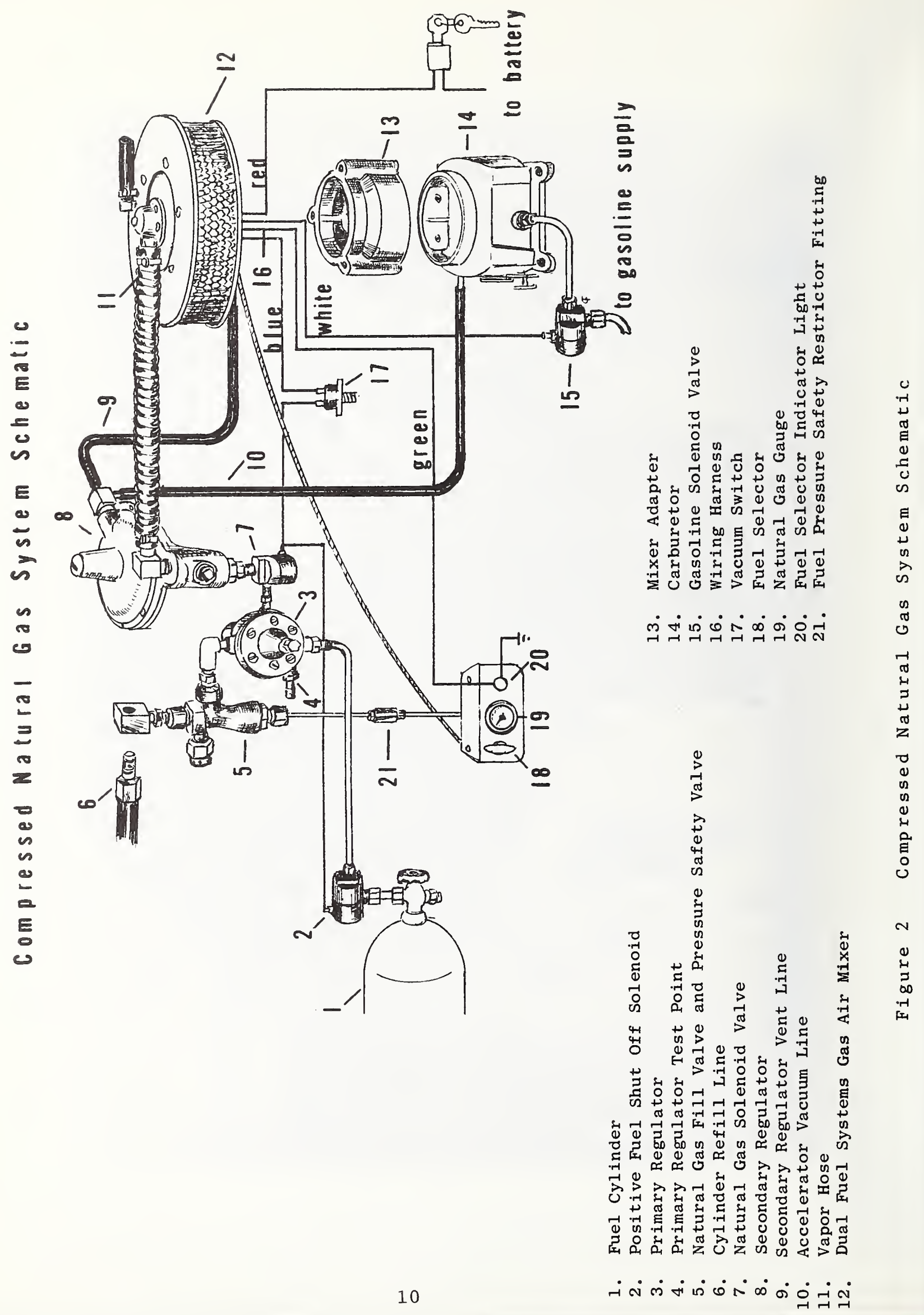




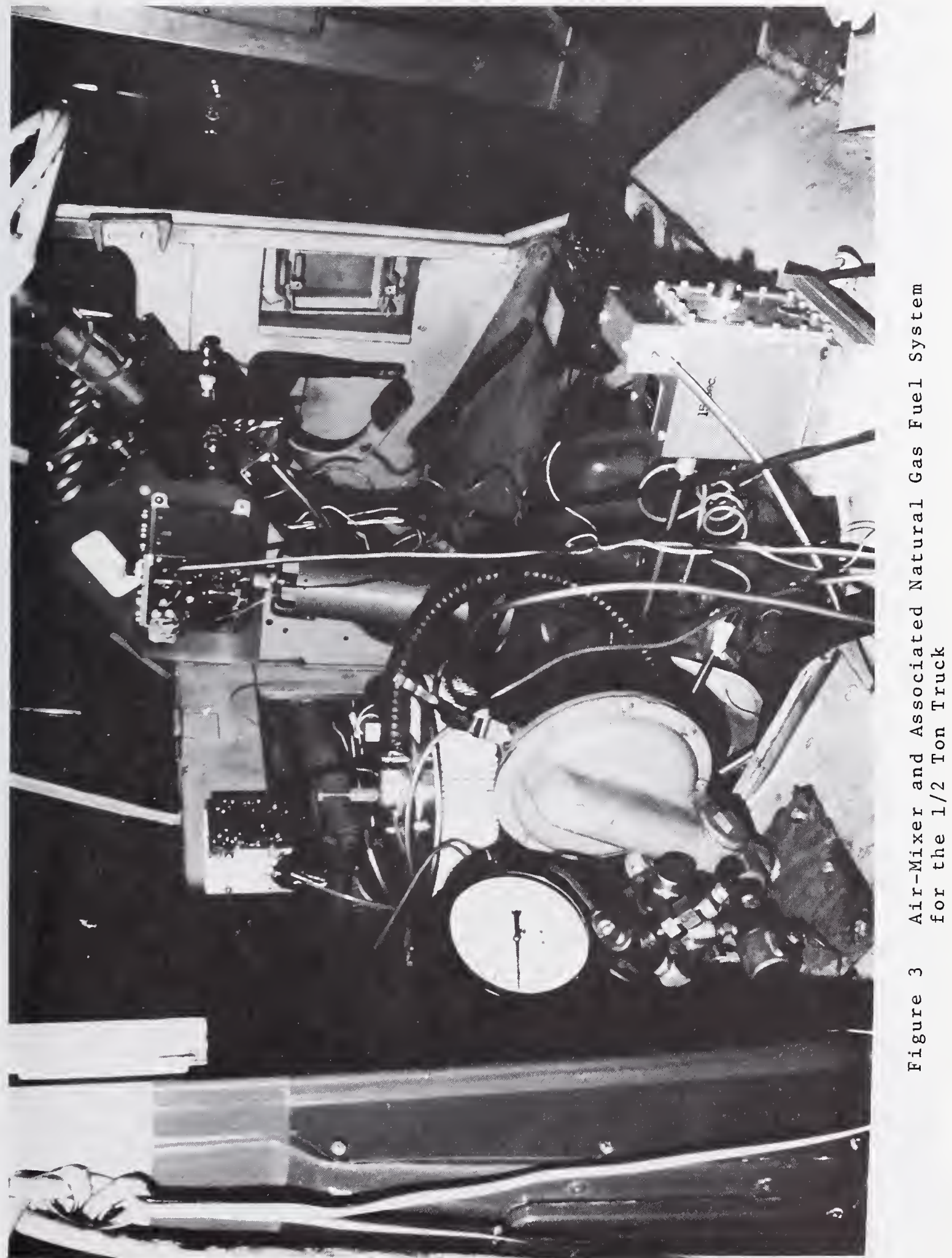


This dual-fuel system was then replaced with the necessary equipment so that a series of tests could be run using both gasoline and propane as the fuels. LPG was run from cylinders typically used with campers and small house trailers (see Figure 4) through a vaporizer and regulator into an air cleaner shown in Figure 5. The gas regulator prominently shown in Figure 5 to the left of the air cleaner was used for the CNG tests and was completely bypassed for the tests involving LPG.

There was one basic difference in the two systems described above that should be noted. The regulator-vaporizer controlled downstream pressure at a constant preset level for both systems. However, in addition, for the LPG dual-fuel system there was a restrictor in the gas line between the regulator and air cleaner (actually an integral part of the inlet port to the air cleaner). The gas flow adjustment for the CNG system was made by adjusting the gas pressure at the regulator. For the LPG system, it was made by changing the position of the restrictor. Although, it would appear to make no difference whether the gas flow was adjusted by changing the driving force (pressure) or by changing the flow resistance, there was a substantial difference in the way in which the gas flow was controlled in the two systems as the vehicle speed and load changed. This will be discussed more fully in the Results and Discussion Section. 


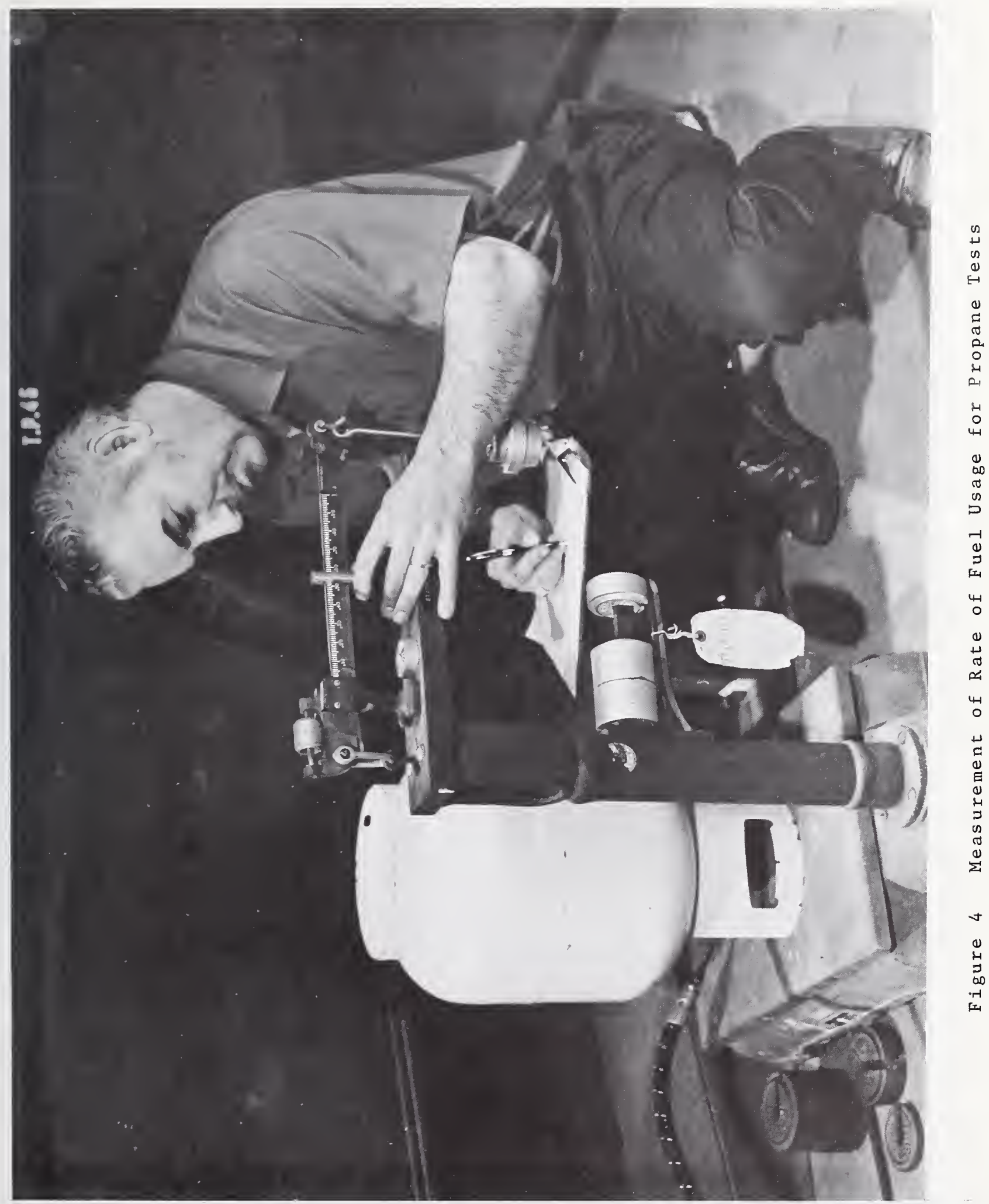




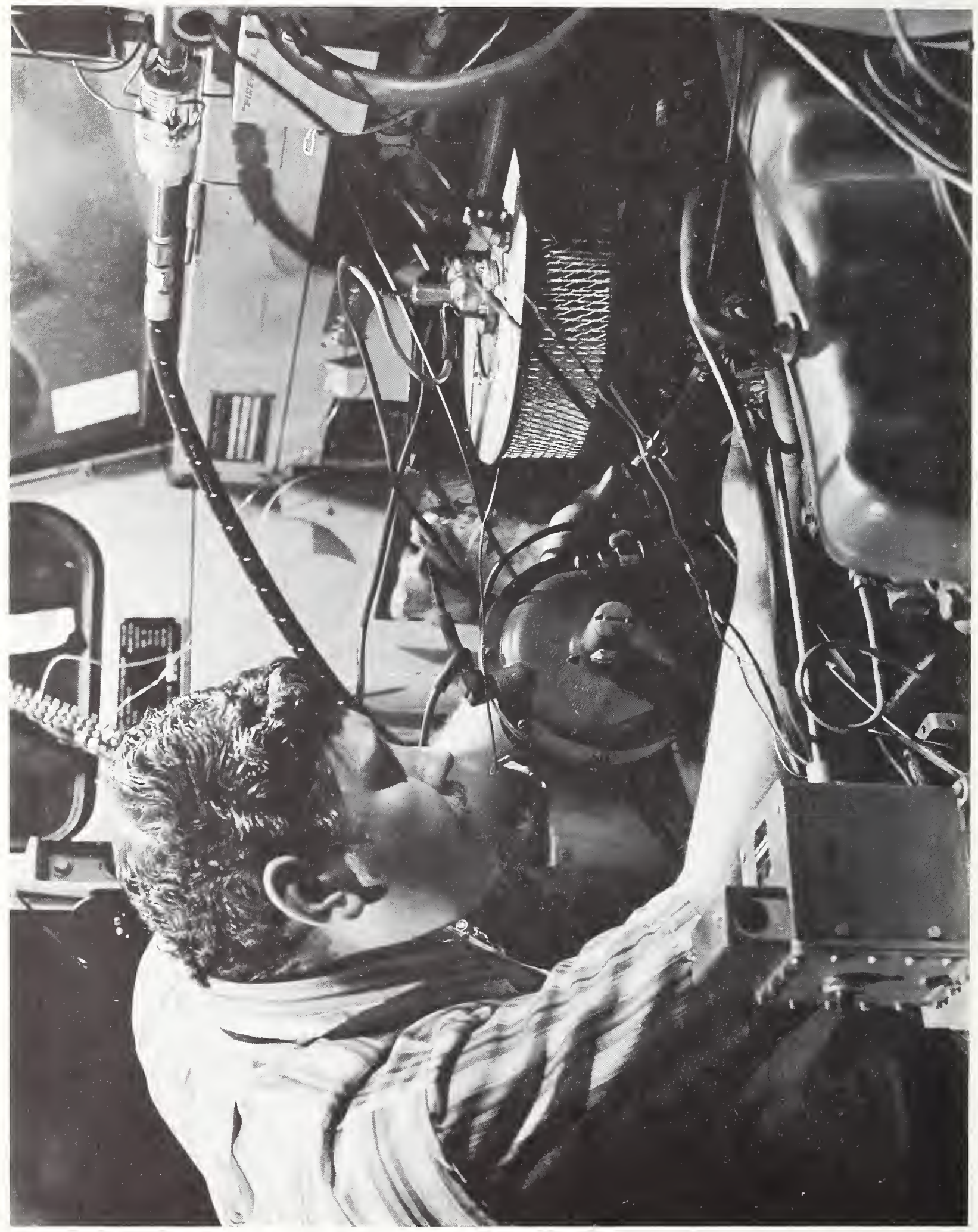

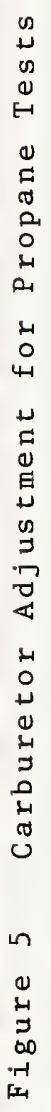


2.21 Ton Truck

The 1 ton truck is shown in Figure 6. It was equipped with a 225 cubic inch 6 cylinder engine. The particular dual fuel system installed on this vehicle was a different make but worked basically the same way as the other systems. The major differences were in the carburetion and the way in which the flow of gas to the carburetor was controlled. Where the other systems used an air-mixer, this system fed the gas at a constant pressure into the throat of a venturi that was mounted on top of the gasoline carburetor. The venturi insert can be seen on top of the carburetor in Figure 7. The gas flow to the insert could be adjusted by changing the position of a power valve which is nothing more than a screw valve or restrictor that provided additional resistance to the flow (right before entering the carburetor) as it was turned in and blocked off the flow path. The stem of the screw is seen protruding out from behind the carburetor in Figure 7 . Therefore one would expect the system to perform very similar to the LPG dual-fue 1 system used on the $1 / 2$ ton truck. 


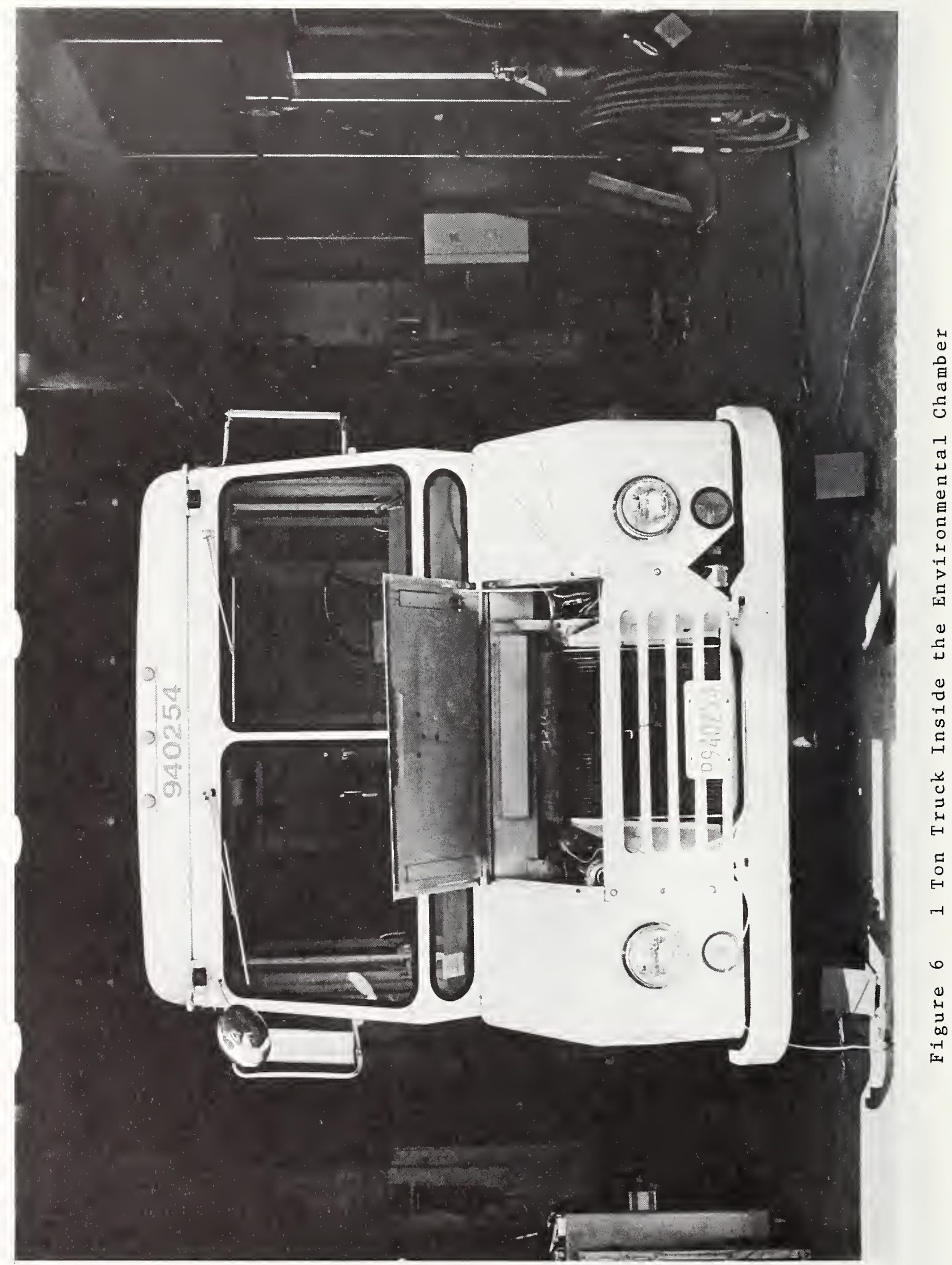




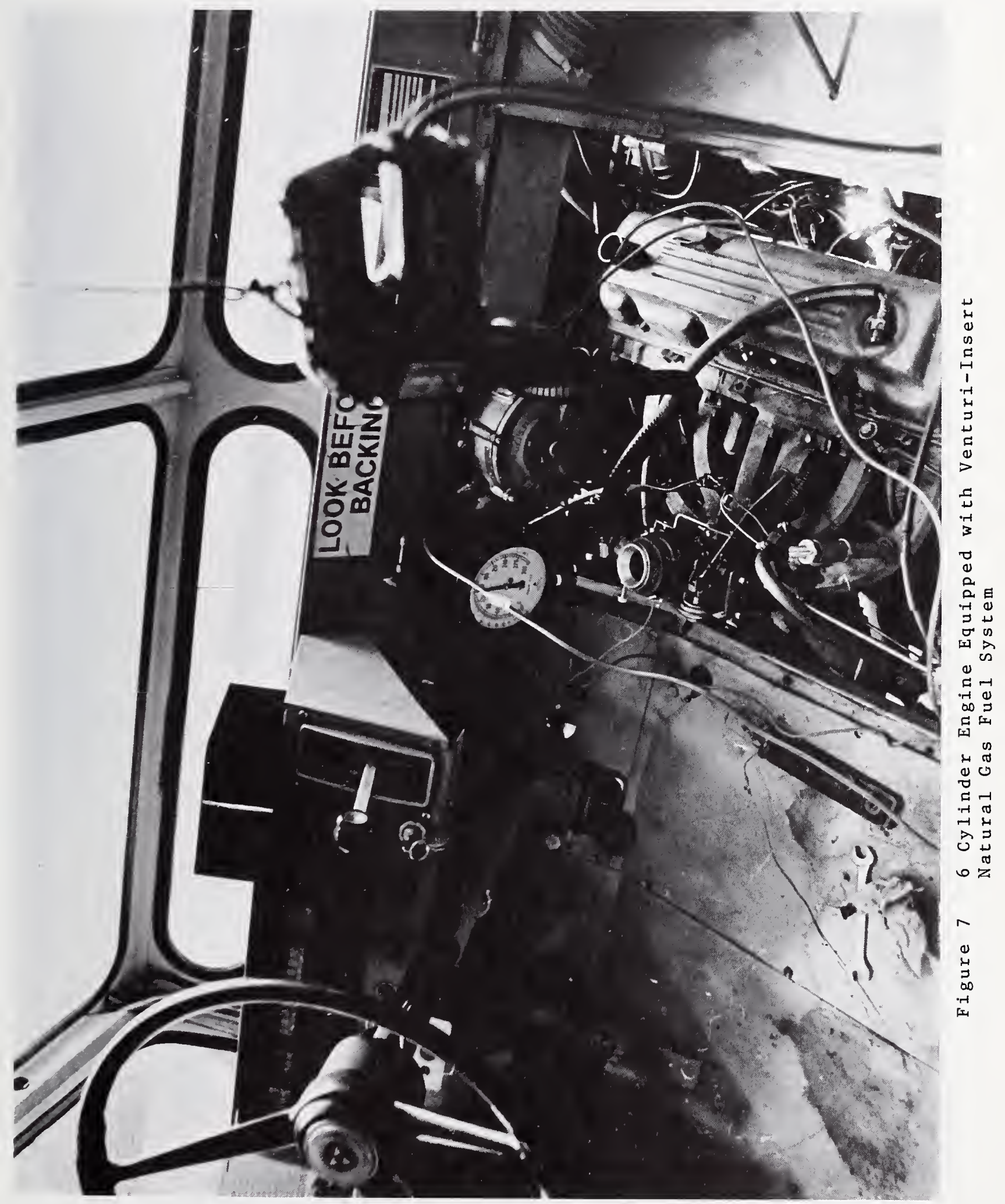


3. Test Apparatus and Procedure

In order to determine the mechanical performance and emission characteristics of the vehicles at different temperatures, they were tested in an environmental chamber where the temperature could be controlled over the range $-50^{\circ} \mathrm{F}$ to $150^{\circ} \mathrm{F}$. The vehicles were mounted so that the rear wheels rested in a chassis dynamometer (Mode1 C-200 made by the Clayton Manufacturing Company*) as shown in Figure 8. One of the rollers is connected directly to a tachometer generator and associated speed meter for determining the vehicle speed while the other roller is attached directly to a power absorption unit which provides the load for the truck. The power absorption unit consists of a shaft, rotor, stator and heat exchanger enclosed within a housing. The rotor is mounted on the shaft with its vaned face directed toward the vaned face of the stator. When a vehicle is operated on the rolls, the rotor turns at roll speed. Fluid in the power absorption unit is picked up by the rotor vanes and thrown into the stator vanes. The stator vanes stop the movement of the fluid, returning the fluid to the rotor. Constant acceleration of the fluid by the rotor and deceleration by the stator absorbs vehicle power. The load is varied by varying the amount of fluid allowed into the unit.

\footnotetext{
*Trade names are used in this report as a means for clear identification to the Postal Service of their property. Use of a trade name neither constitutes nor implies endorsement by the National Bureau of Standards.
} 


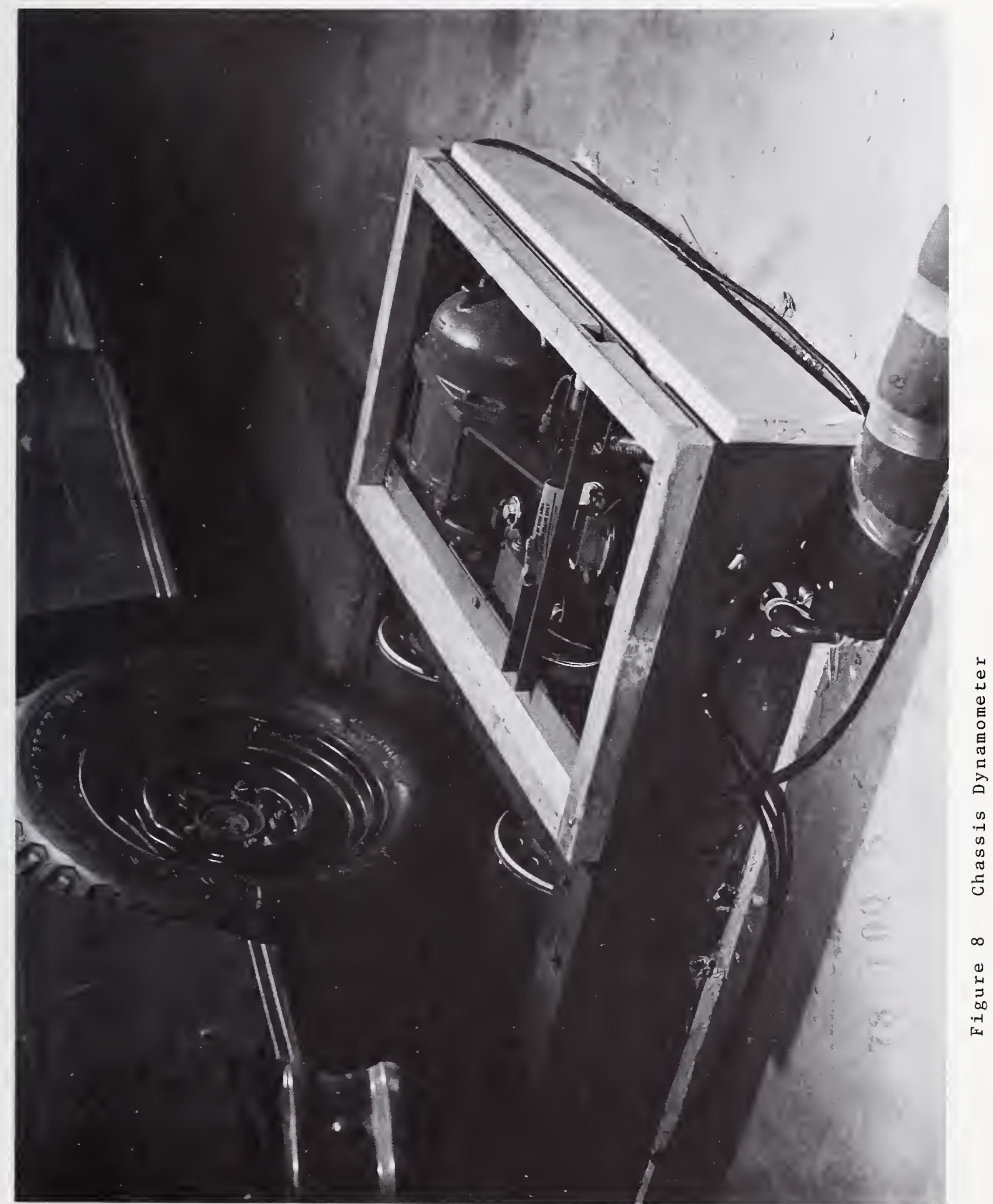


Measurements of rotor speed and generated torque are combined electrically to display the power generated on an appropriate power meter (shown in the upper part of Figure 9).

once the vehicle was running at a specified speed and load at a particular chamber temperature, a series of measurements were made in order to determine the pollution and mechanical performance characteristics of the vehicle. These measurements are indicated in the schematic of Figure 10. As already noted, the road speed and horsepower were determined from the meters associated with the dynamometer. Standard 24 gauge copperconstantan thermocouples were used to determine ambient air temperature in front of the radiator, water coolant temperature, inlet air temperature at the carburetor, and the temperature of exhaust pipe before the exhaust gas enters the muffler. The temperatures were read on a potentiometer connected in series with a multipoint thermocouple switch:

A variety of pressure measurements were made during the tests. The fuel pump pressure (for gasoline operation) was measured using a conventional bourdon-tube pressure gauge mounted in the cab of the truck. A similar gauge indicating in inches of Hg. vacuum was used to measure the intake manifold pressure. The manifold was tapped and connected to the gauge in the adjoining instrument room using $1 / 8$ inch copper tubing. In a similar manner, the gas pressure following the second stage gas regulator and the exhaust pressure were measured by taps connected to water manometers in the instrument room. 


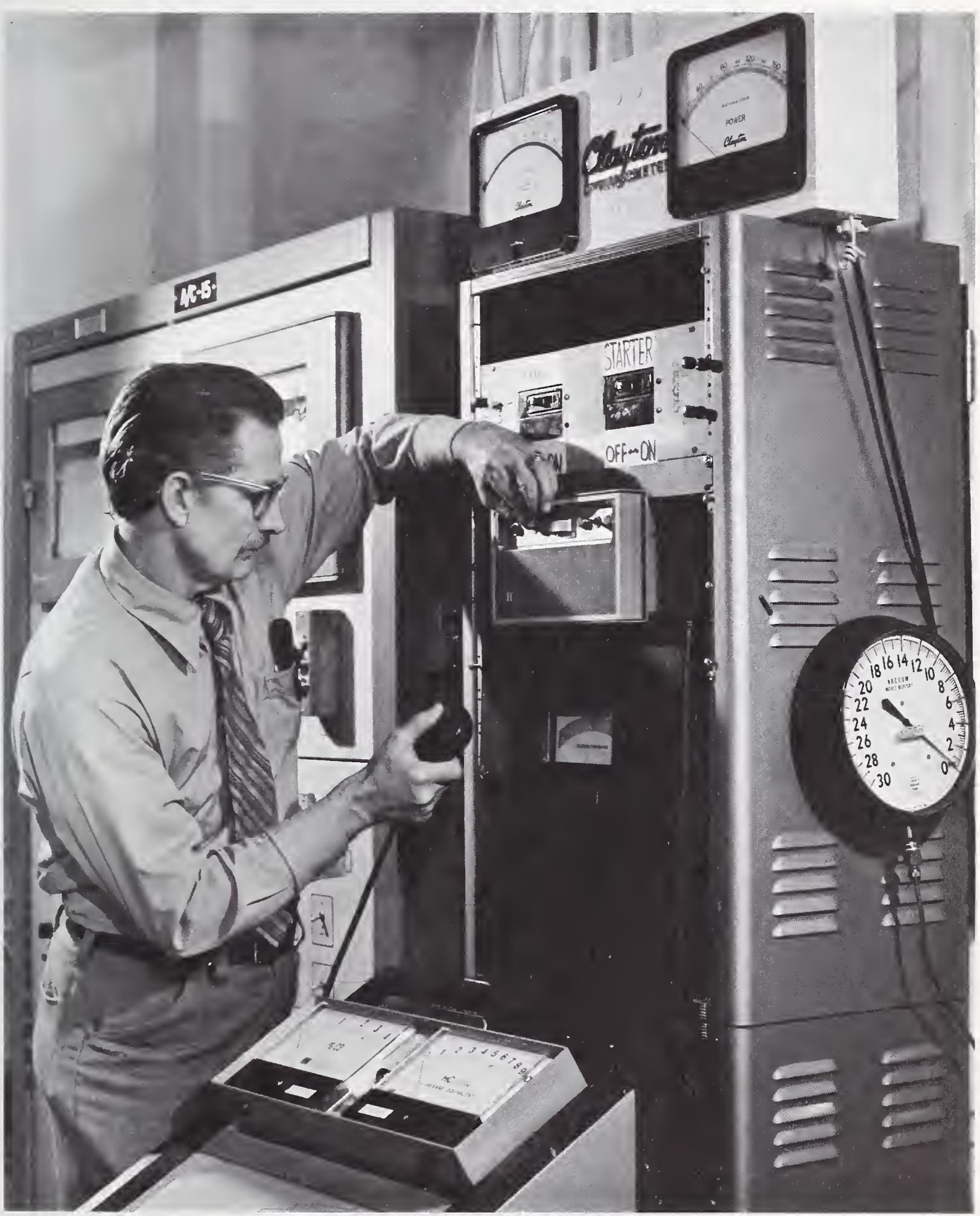

Figure 9 Engine Throttle Position and Dynamometer Adjustments Being Made from the Instrumentation Room 


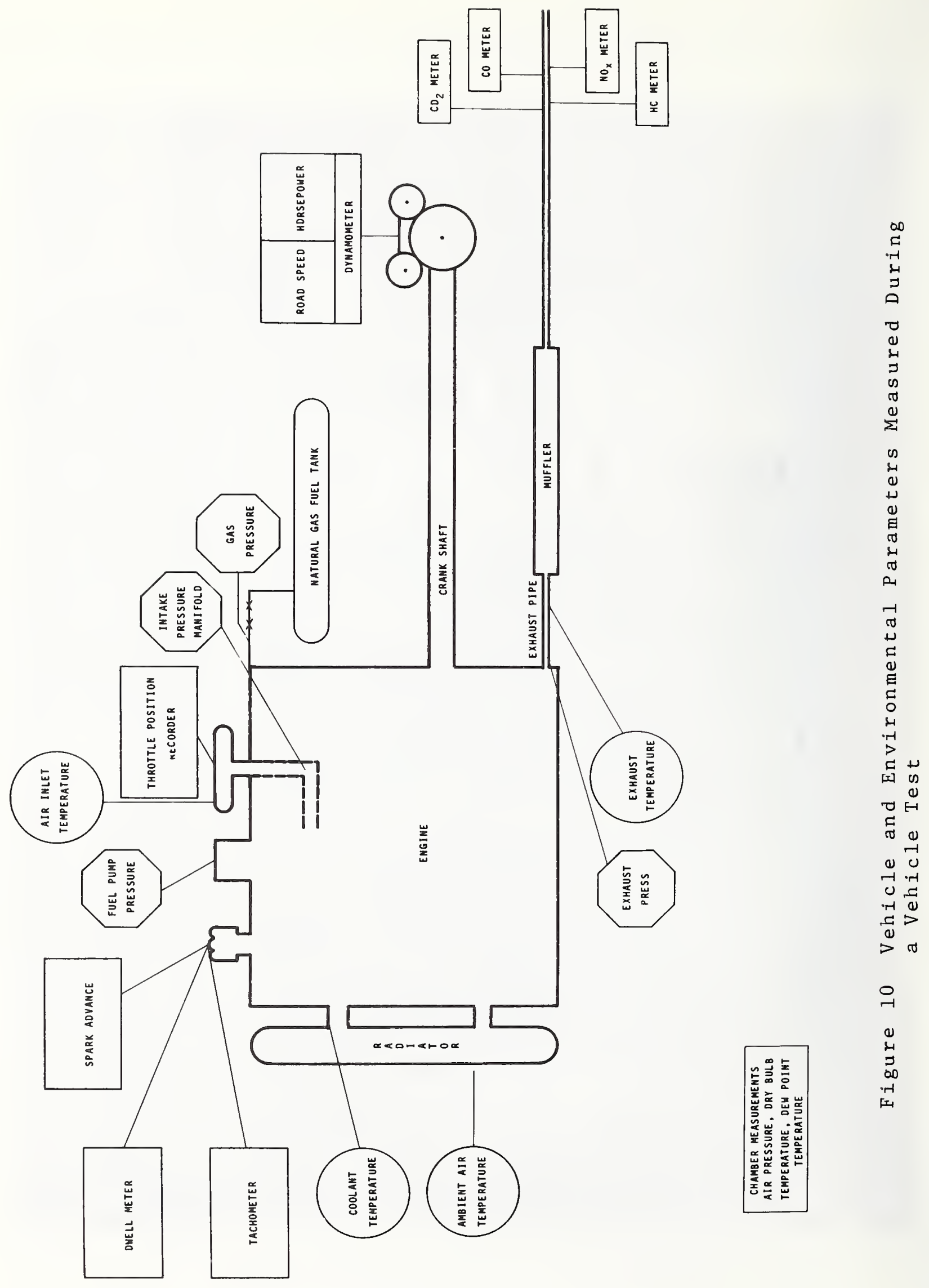


Additional pressures at several places in the gas flow system were monitored by bourdon-tube gauges. The purpose of these later measurements were to insure proper operation of the systems and a sufficient gas supply in the tanks at all times. A tach-dwe 11 tester manufactured by the Sun Electric Corporation* (Mode1 TDT-11) was used to measure the degrees of dwe11 and engine speed. A conventional timing 1 ight hooked in series with the spark plug of the first engine cylinder allowed measurement of the spark advance. A throttle position recorder was used because the throttle position was controlled from the adjoining instrumentation room (shown being done in Figure 9). This recorder consisted of a small electric slavemotor and shaft at ached to the throttle linkage at the engine and a master motor was in the adjacent instrument room. The position of the master motor indicated degree of throttle opening between 0 and $100 \%$ (full throttle). A small servomotor system was used to adjust the distributor for setting the spark advance on the $1 / 2$ ton truck. The system was calibrated with the timing 1 ight and checked frequently. It was not mechanically convenient to install the system in the 1 ton vehicle so the distributor was adjusted manual1y.

$\mathrm{CO}, \mathrm{HC}$, and $\mathrm{NO}_{\mathrm{x}}$ emission measurements were made. In addition, $\mathrm{CO}_{2}$ was measured so that the air-fuel ratio could be

* Trade names are used in this report as a means for clear identification to the Postal Service of their property. Use of a trade name neither constitutes nor implies endorsement by the National Bureau of Standards. 
determined for any particular test by exhaust gas analysis. The exhaust gas was sampled by withdrawing part of the mixture from the exhaust pipe (see Figure 11), bubbling it through glass traps containing water to condense out the excess water vapor and then passing it to the various analyzers. A11 analyzers were calibrated by periodically measuring the pollutant content of containers of standard "span gas." An 01son-Horiba* Mode1 GSM-300 was used to measure the content of CO and $\mathrm{HC}$ and a Lira* Model 300 to measure the $\mathrm{CO}_{2}$ content (see Figure 12). Both instruments operate on the principle of absorption of infrared energy by gas. Two identical infrared beams are passed through two para11e1 stacked ce1ls. One ce 11 contains a gas of known composition and the other the sample gas. After the radiation beams pass through the cells, they are directed into detector units. Upon comparison of the two beams, an electrical signal is generated proportional to the amount of the component of interest in the sample gas. A Dynasciences* Air Pollution Monitor Model NX-130 was used to determine the amount of nitric oxides in the exhaut gas (shown being adjusted in Figure 12). The sensor operates on the principle similar to a fuel cell. The pollutant diffuses through a semi-permeable membrane and is absorbed on a special sensing electrode capable of undergoing electrooxidation or electro-reduction. The resulting current is

* Trade names are used in this report as a means for clear identification to the Postal Service of their property. Use of a trade name neither constitutes nor implies endorsement by the National Bureau of Standards. 


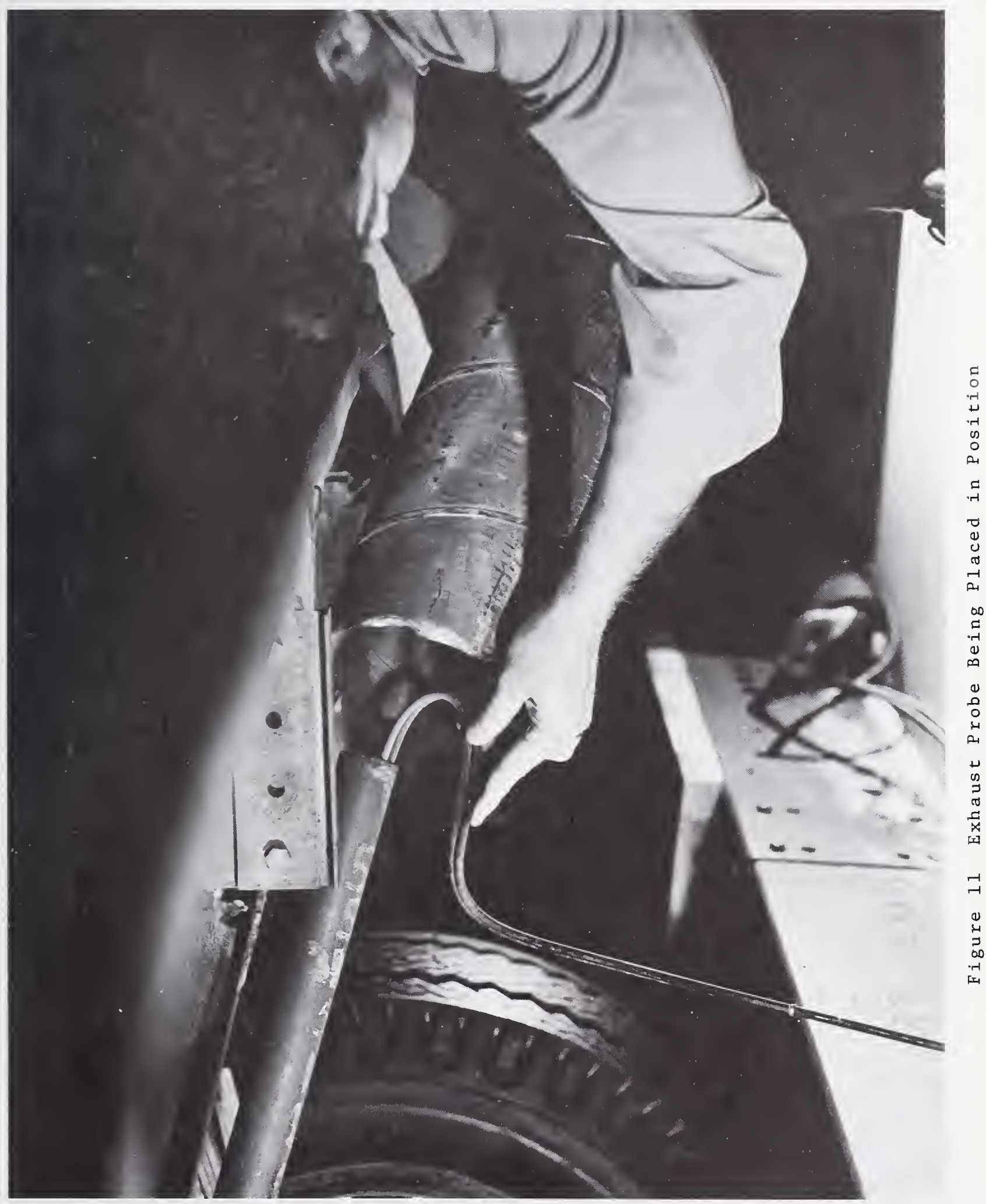


directly proportional to the partial pressure of the pollutant in the gas mixture. This current is amplified and the output of the amplifier is displayed on an appropriate meter. Since the temperature of the sample gas should be approximately room temperature and the response time of the meter is an optimum with a flow rate of 0.5 to 2.0 standard cubic feet per hour, a Dynasciences* Stack Sampling System (Model CS-1000) was connected in series between the exhaust probe and the NO analyzer (see Figure 12). The sampler houses a diaphragm pump, heat exchanger (requiring a cold water supply), condensate trap, and a flow meter with a built-in metering valve.

The nature of the tests conducted was such that a certain step by step procedure was not established and then followed throughout the entire investigation. The number of independent variables involved coupled with the unique way in which the vehicles and their systems performed required modifications in the procedures as the project progressed. An attempt will be made here to describe the testing steps common to all tests and any deviations will be noted in discussing the tests results.

In general three kinds of tests were conducted: spark advance tests, air-fuel ratiotests, and start tests at low

* Trade names are used in this report as a means for clear identification to the Postal Service of their property. Use of a trade name neitner constitutes nor implies endorsement by the National Bureau of Standards. 


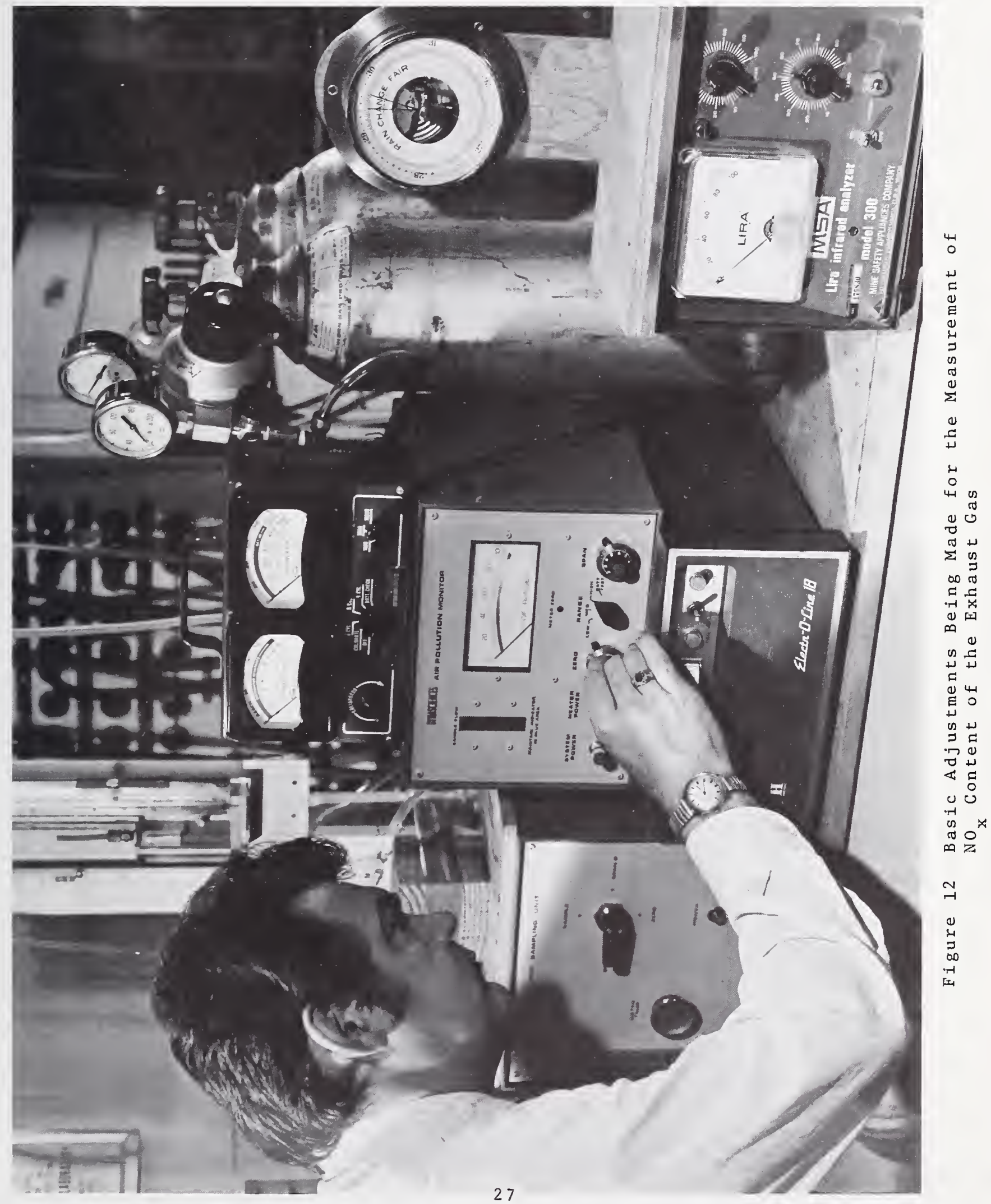


temperatures. In a 11 cases, the chamber temperature was adjusted to and controlled at a prescribed level using the control system and sensors permanently housed in the environmental chamber facility. All chamber air temperature data used was measured in front of the vehicle at the radiator. While the chamber temperature was being brought to the correct level, all instrumentation systems were powered. The time allowed for warm-up was in all cases from a minimum of several hours to overnight. In addition, no data were recorded on either vehicle running at any speed or load until it was assured that steady-state conditions had been reached. This was determined by observing no change in vehicle coolant temperature or pollutant readings for at least five minutes. For the start-tests, the vehicles were allowed to soak at the low temperature for at least 20 hours prior to attempting to start the trucks.

Spark advance tests were conducted on the trucks runing on natural gas, propane and gasoline. Since the gasoline carburetor jets are fixed, there were no prior adjustments to be made in the fuel system. For the natural gas and propane tests, specific settings were made in the gas flow system. For the $1 / 2$ ton truck, it was the second stage regulator pressure when using CNG and the position of the restrictor when using propane. For the 1 ton truck it was the position of the power valve or restrictor. In addition, on the $1 / 2$ ton truck using CNG, an adjustment at the air-mixer (on a screw-valve called 
the tweeker) had to be made. This screw-type adjustment had an effect on the resulting air-fuel ratio (as did the secondstage regulator pressure). The procedure that was followed in all tests (spark advance as well as air-fuel ratio tests to be described next) was to adjust this tweeker to as lean a mixture as possible (determined by the smallest reading on the co meter) and still obtain a good idle (indicated by smooth running with no missing). After these basic gas flow adjustments were made, the spark advance tests were conducted by starting the vehicle, adjusting the idling to 550 rpm and setting the distributor so that cylinder firing occurred at top dead center. The throttle was moved until a specific simulated road speed was obtained. The dynamometer was then adjusted to a certain load, and the throttle readjusted if necessary, to give the required road speed. After all indicators stablized, the various readings indicated in Figure 10 were recorded. The distributor was then adjusted so that the firing was advanced three degrees and after steady conditions were reached, all new readings were tabulated. This procedure was continued until the spark has been adyanced by at least $12^{\circ}$ and in some cases even more. After the last distributor adjustment, the dynamometer and vehicle throttle were changed to another speed and load of interest, the distributor readjusted to obtain idle firing at top dead center and the entire procedure was repeated. 
Air-fuel ratio tests could not be conducted on the vehicles using gasoline as no adjustment would normally be made on fuel flow. The procedure followed when using CNG or propane was to adjust (while the vehicle was idling) the distributor for a specific spark advance and the basic gas flow adjustment to a very lean condition. The leanest setting possible on any one vehicle sometimes depended upon the speed and load to be used in the test. On the $1 / 2$ ton truck using CNG, the idle gas pressure was adjusted generally to 1.5 inches of water gauge (and the tweeker adjusted as noted previously). On the $1 / 2$ ton truck using propane, the restrictor was placed in the No. 2 position (see Figure 13). On the 1 ton truck, the power valve was screwed out 7 or 8 turns from full in (out of a possible 22 or 23 turns). After the truck was running at the required speed and Ioad and all data had been recorded, the gas flow adjustment was than changed to a slightly richer position ( 1.5 inches of $\mathrm{H}_{2} \mathrm{O}$ higher in idle gas pressure for the $1 / 2$ ton truck using $C N G$, one number higher in restirctor position for the $1 / 2$ ton truck using propane., and 2 or 3 more turns out on the power valve for the 1 ton truck). This procedure was continued until the richest running possible was obtained and then the speed and load were changed and the entire procedure repeated.

The third series of tests involved determining the engine's ability to start at very cold temperatures (see Figure I4). Both CNG and gasoline fuel were used. A particular gas flow 


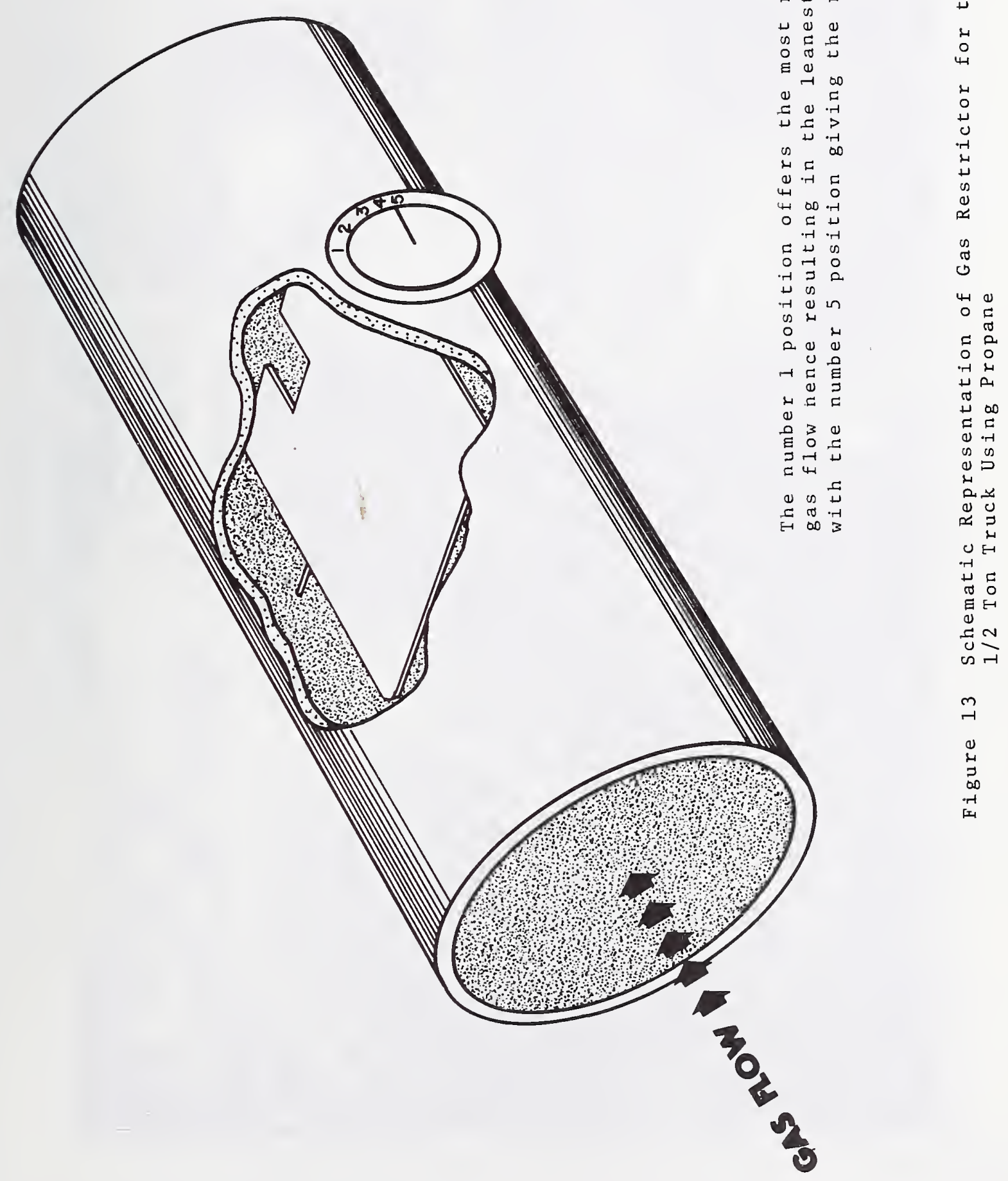




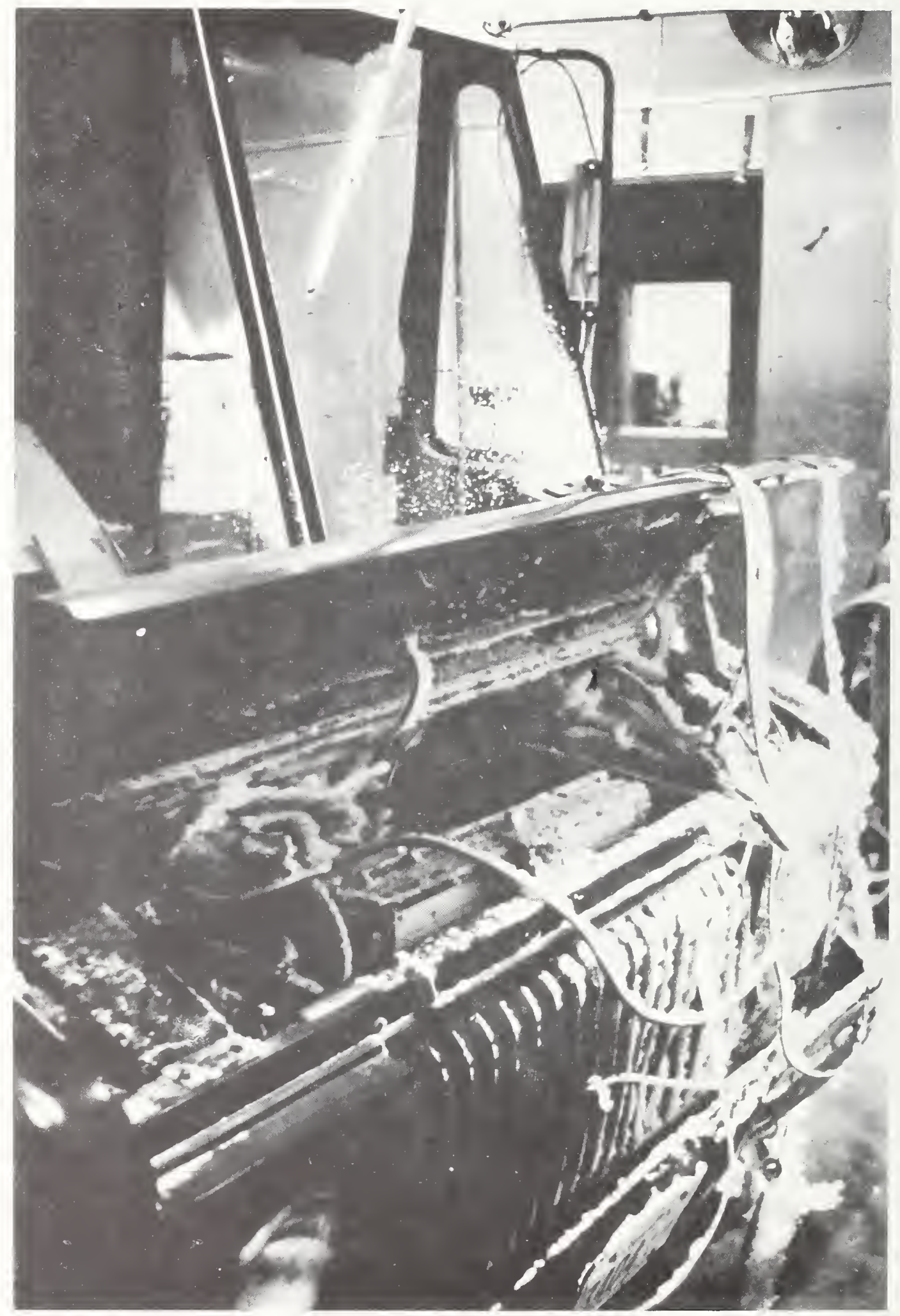

Figure $141 / 2$ Ton Truck During Cold Start Tests 
adjustment and spark advance setting were made and the starter was turned over generally for 10 to 15 seconds (or until the vehicle started). A qualitative statement was then recorded as to whether the engine started, fired, or failed to even fire. In each case where it started, the engine was immediately turned off and sufficient time was given for the coolant temperature to return to its original value prior to changing the spark and gas flow adjustments and attempting to start the engine again. The battery voltage was measured periodically and a battery charger was used whenever the voltage was below an acceptable limit. The one additional parameter involved in this series of tests was the use of a capacitive discharge ignition unit (CDI) added to the vehicles. The unit consists of an oscillator which changes the 12 volt DC battery voltage to approximately 500 volts AC. The AC output is then rectified to 400 volts DC and is stored on a high voltage capacitor. When the points open, a silicon controlled rectifier allows the power to be discharged into the primary of the coil. The higher voltage should assure more complete combustion and better starts. The effect this CDI unit had on the starting capability of the engines will be discussed in the Results and Discussion Section. 
4. Results and Discussion - $1 / 2$ Ton Truck

Figures 15 through 77 show the results of tests conducted on the $1 / 2$ ton truck. The abscissa in most all cases is either the spark advance measured at idling conditions or the air-fuel ratio at the specific running condition (for the CNG and LPG tests). The air-fuel ratio for methane and propane were determined by exhaust gas analysis. Reference (7) outlines the procedure for determining air-fuel ratios in this manner and additional charts not included in that report which govern the combustion of CNG and LPG were used in this study (Reference 8).

4.1 Gasoline-Fueled Tests

Figures 15 through 23 show the way in which the pollutants varied with spark advance set at idling speed for three different running conditions and three different chamber temperatures while the vehicle was operating on gasoline. As shown in Figures 15, 16 and 17, when the spark was advanced, the No ${ }_{x}$ concentration increased. An explanation is that advancing the spark firing beyond top dead center increases the peak cycle temperature in the cylinder which controls final No concentration. Spark advance simultaneously reduces the exhaust temperature which also causes an increase in the hydrocarbon concentration as shown in Figures 18,19 and 20 . It has been found that as the flame front sweeps across the combustion chamber, a thin layer of mixture adjacent to the cooled walls of the 


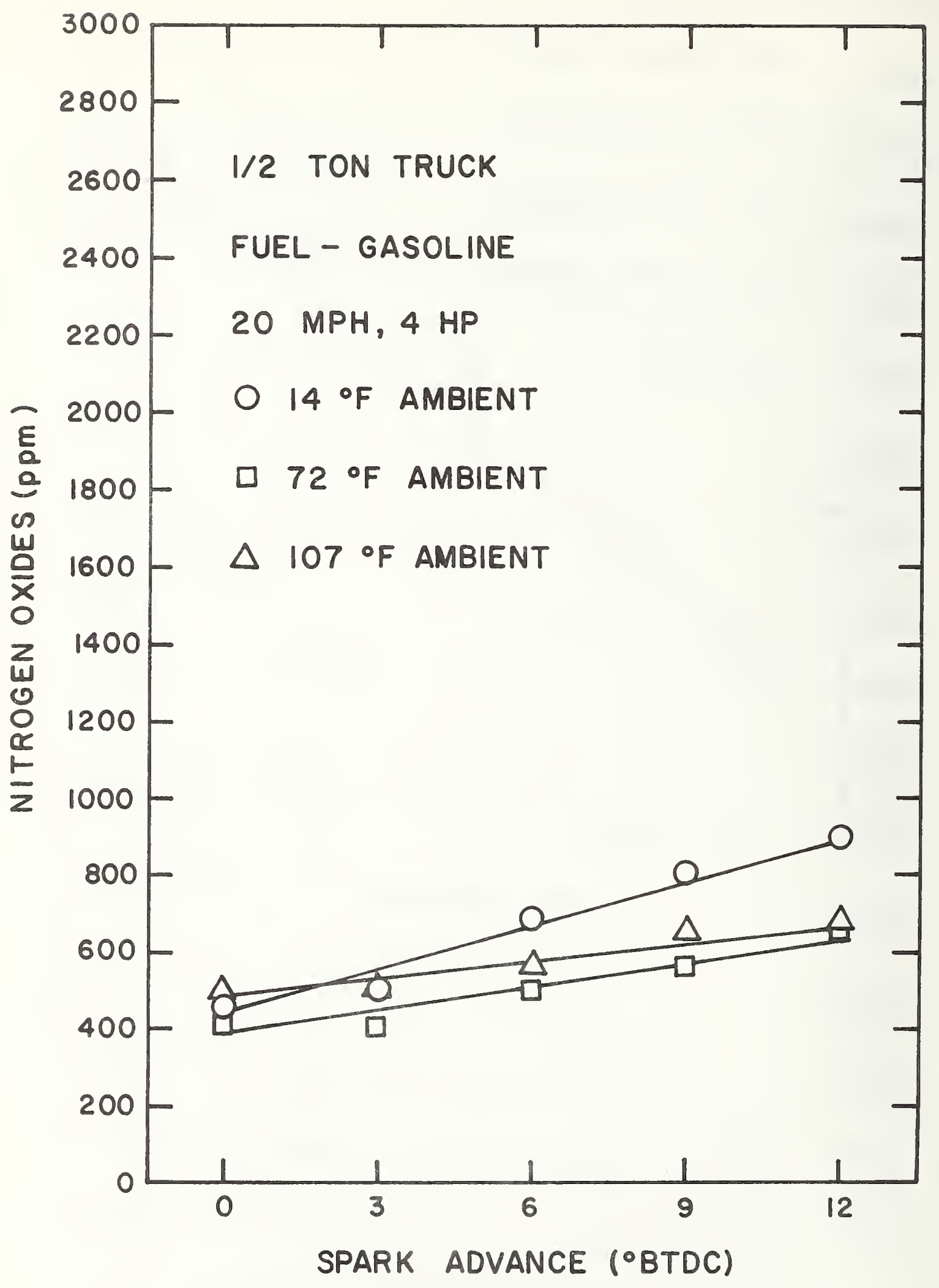

Figure 16 Nitrogen Oxides Versus Spark Advance for a $1 / 2$ Ton Truck Using Gasoline 


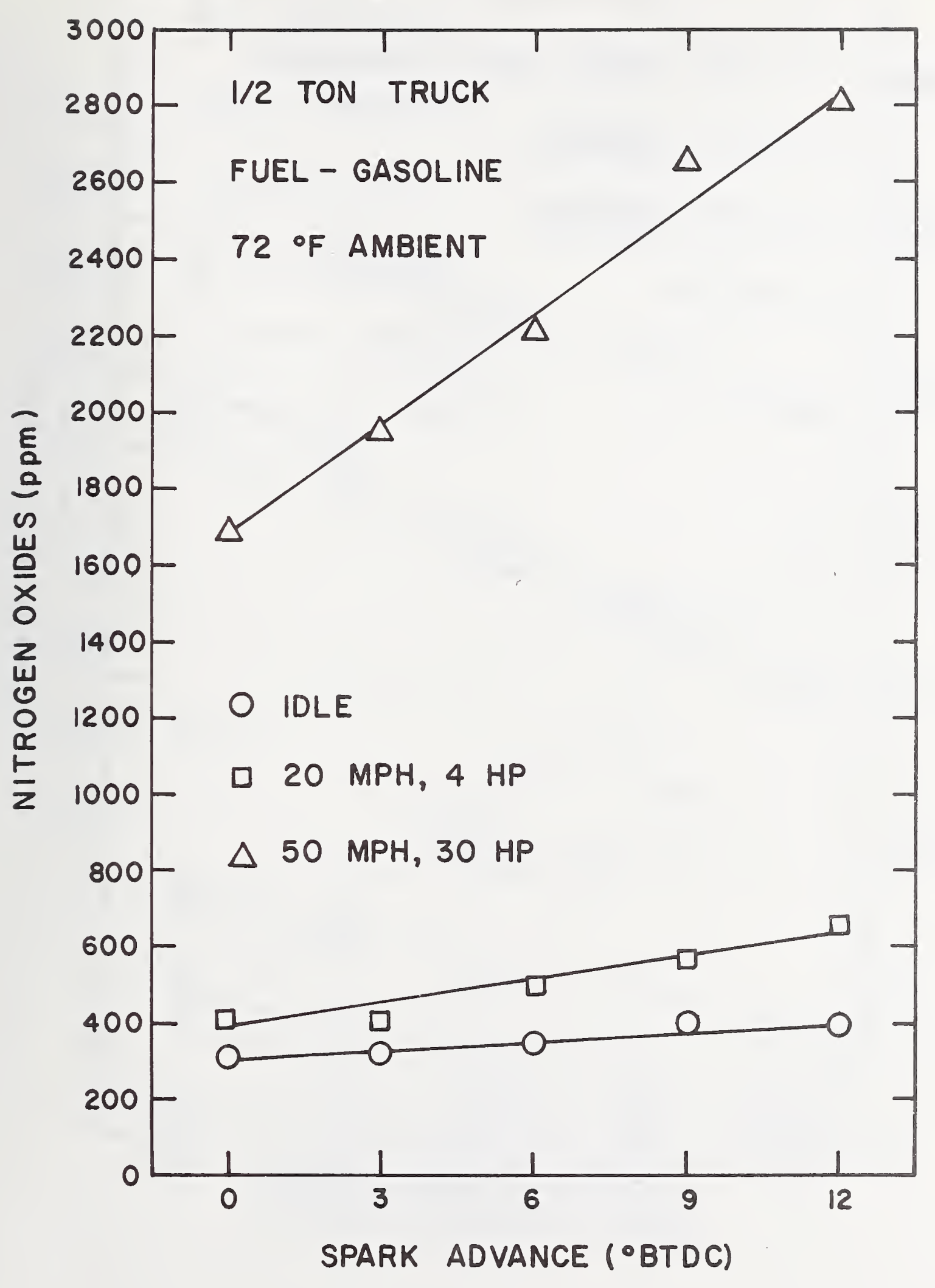

Figure 17 Nitrogen Oxides Versus Spark Advance for a $1 / 2$ Ton Truck Using Gasoline 


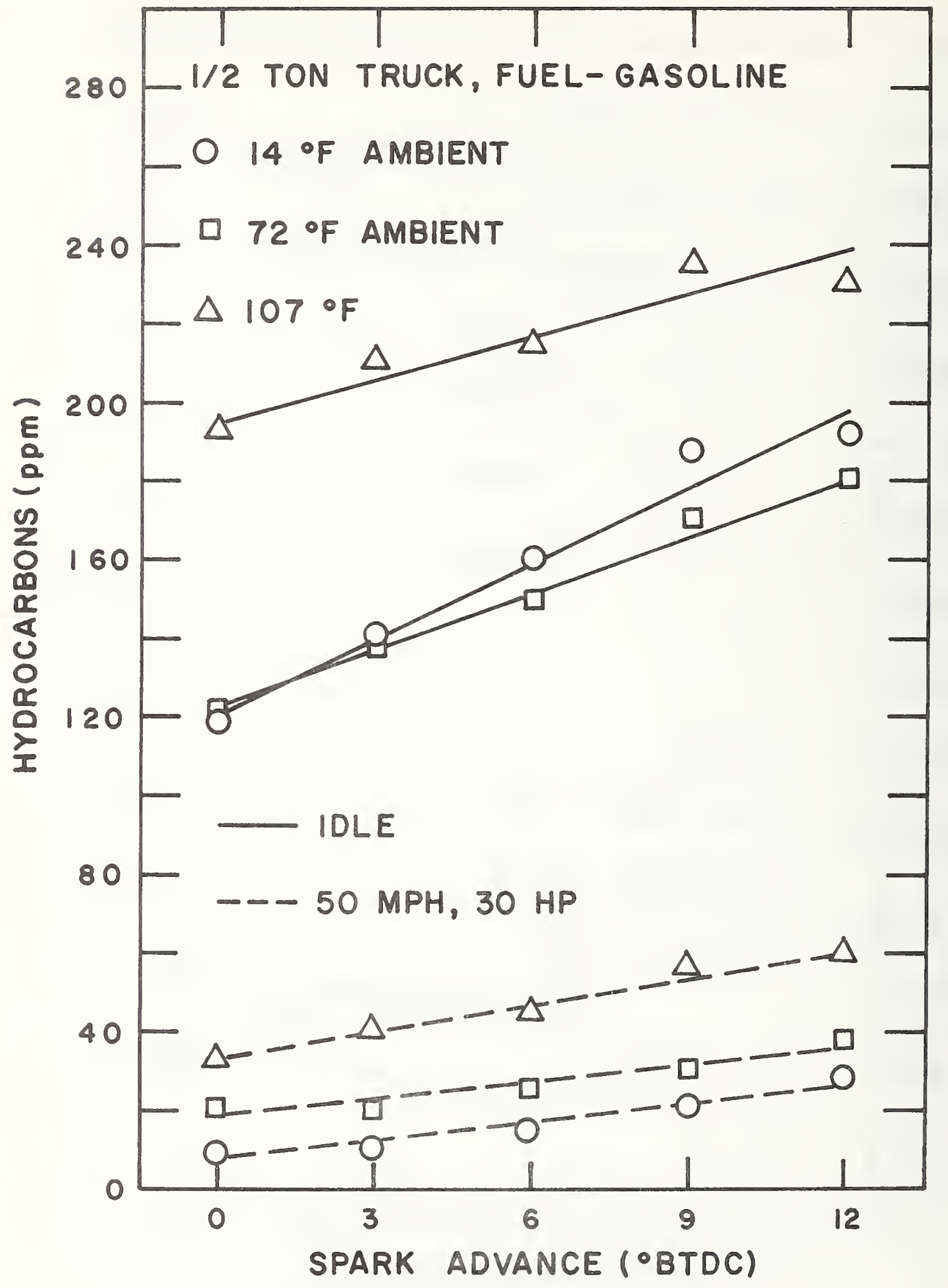

Figure 18 Hydrocarbons Versus Spark Advance for a $1 / 2$ Ton Truck Using Gasoline 


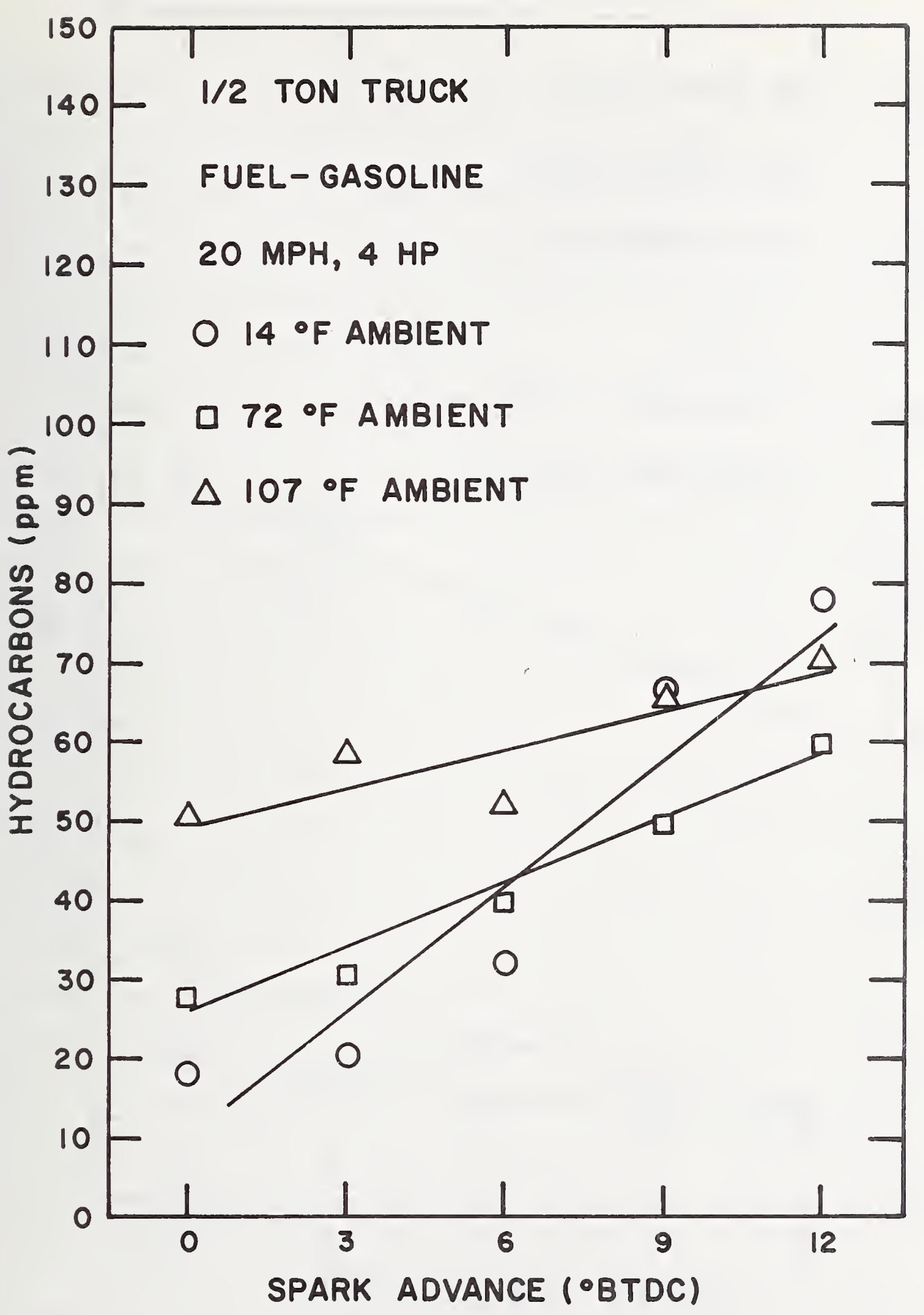

Figure 19 Hydrocarbons Versus Spark Advance for a $1 / 2$ Ton Truck Using Gasoline 


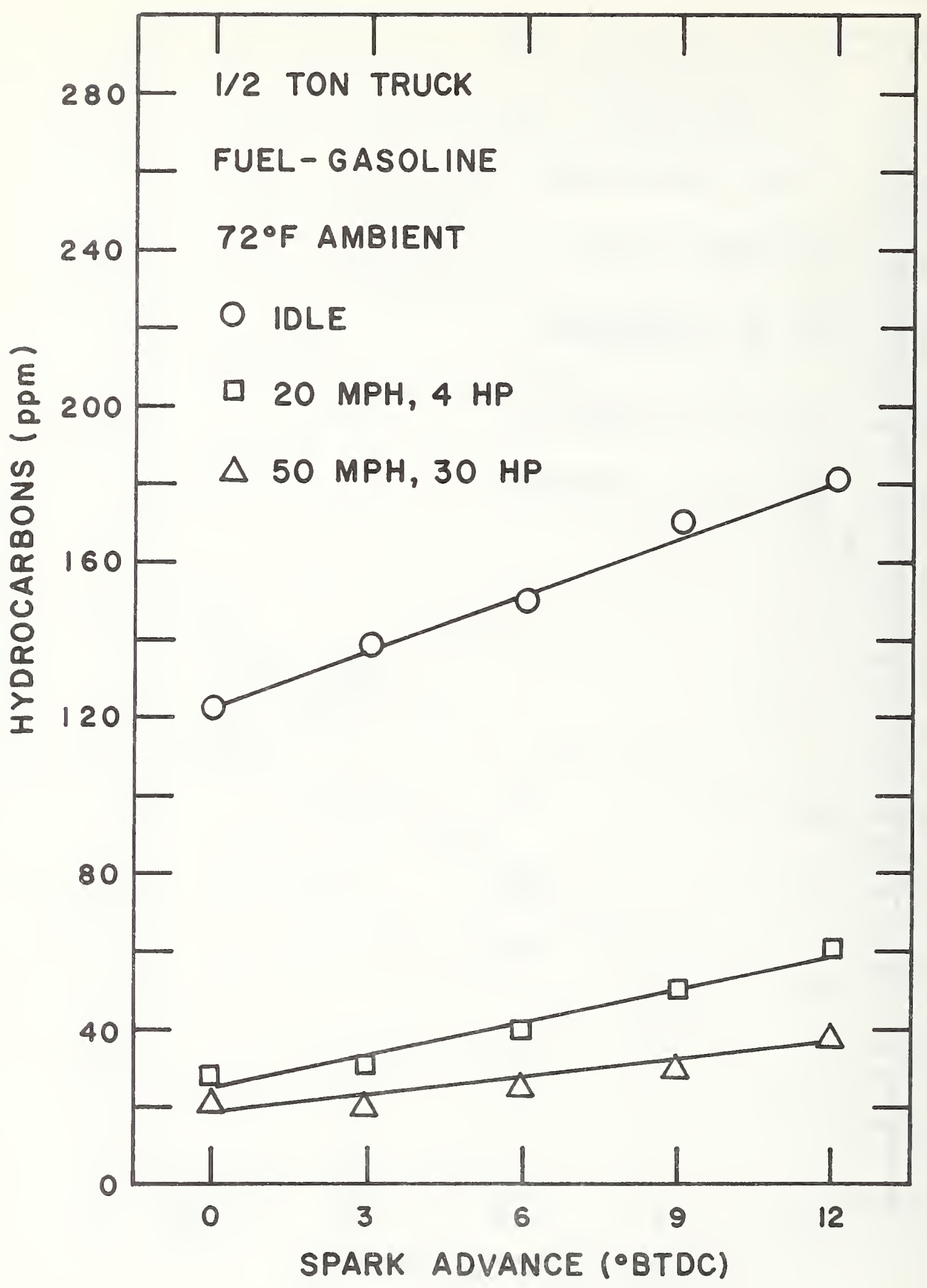

Figure 20 Hydrocarbons Versus Spark Advance for a $1 / 2$ Ton Truck Using Gasoline 
chamber fails to burn (9). Oxidation of this incompletely consumed fuel continues outside of the cylinder in the exhaust system provided that oxygen is present and the gas is hot enough. Consequently, as the exhaust temperature is lowered (as a result of advancing the spark in this case), the hydrocarbon concentration increases.

Provided that sufficient oxygen is present for combustion, advancing the spark should have a minimal effect on the co content of the exhaust gases. This is seen to have generally been true in Figures 21, 22 and 23. The exceptions where there was a marked increase in $\mathrm{CO}$ as the spark was advanced could be explained by the fact that the mixture simultaneously became enriched.

As was noted above, the peak cycle temperature governs the resulting $\mathrm{NO}_{\mathrm{x}}$ concentration. If chemical equilibrium were achieved and maintained during the expansion stroke of the engine cycle, the falling temperature in the expanding gases would reduce the concentration of nitric oxide to a low level. Unfortunately, evidence indicates that this does not occur. Once formed, the $\mathrm{NO}_{\mathrm{x}}$ stabilizes at a concentration typical of equilibrium at the maximum or near maximum temperature achieved. As the vehicle is run faster and at higher loads, this temperature increases explaining the significant jump in $\mathrm{NO}_{\mathrm{x}}$ in Figures 15 and 17 as conditions were changed from iding to $50 \mathrm{mph}$ and $30 \mathrm{mph}$. 


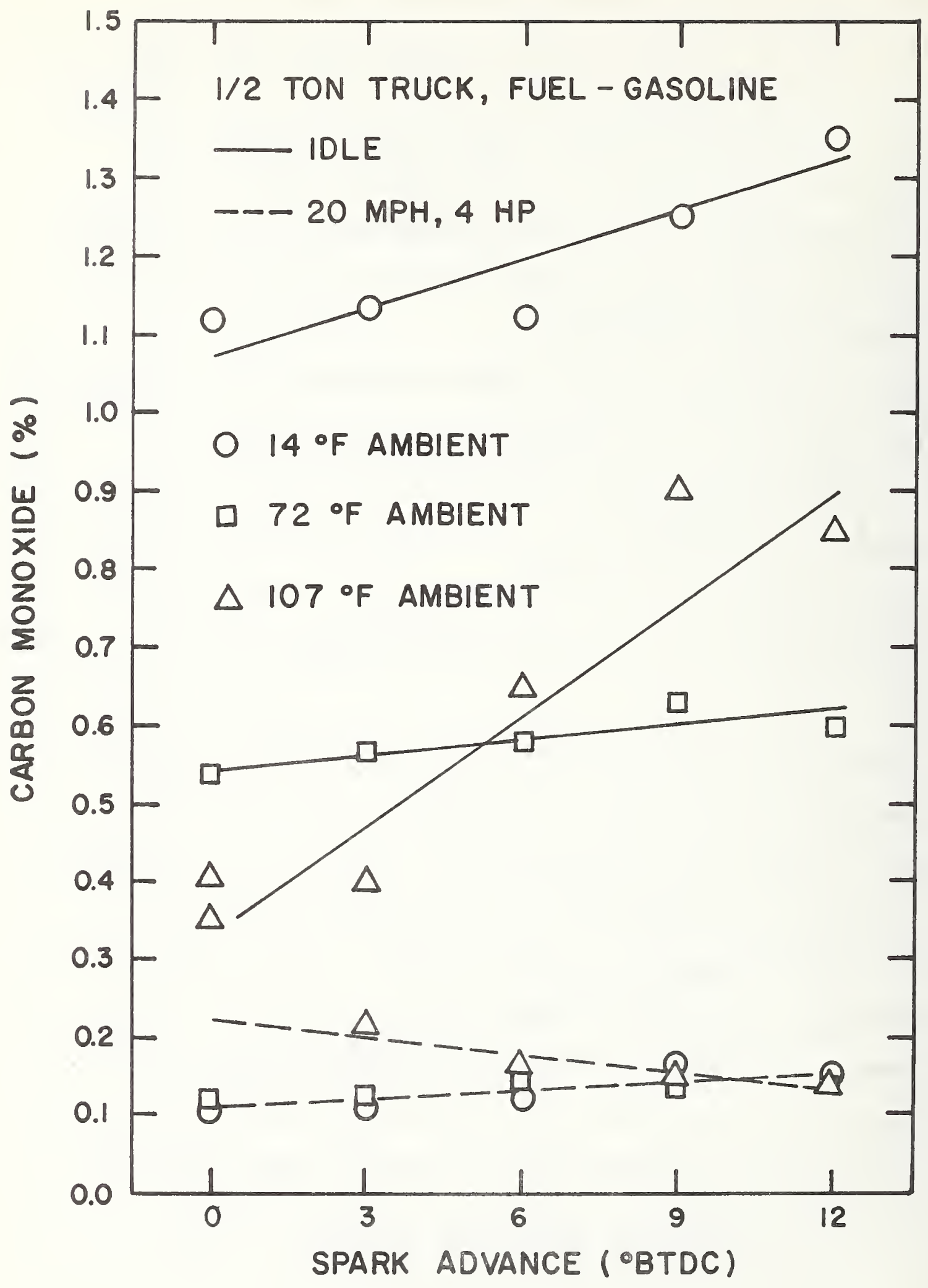

Figure 21 Carbon Monoxide Versus Spark Advance for a $1 / 2$ Ton Truck Using Gasoline 


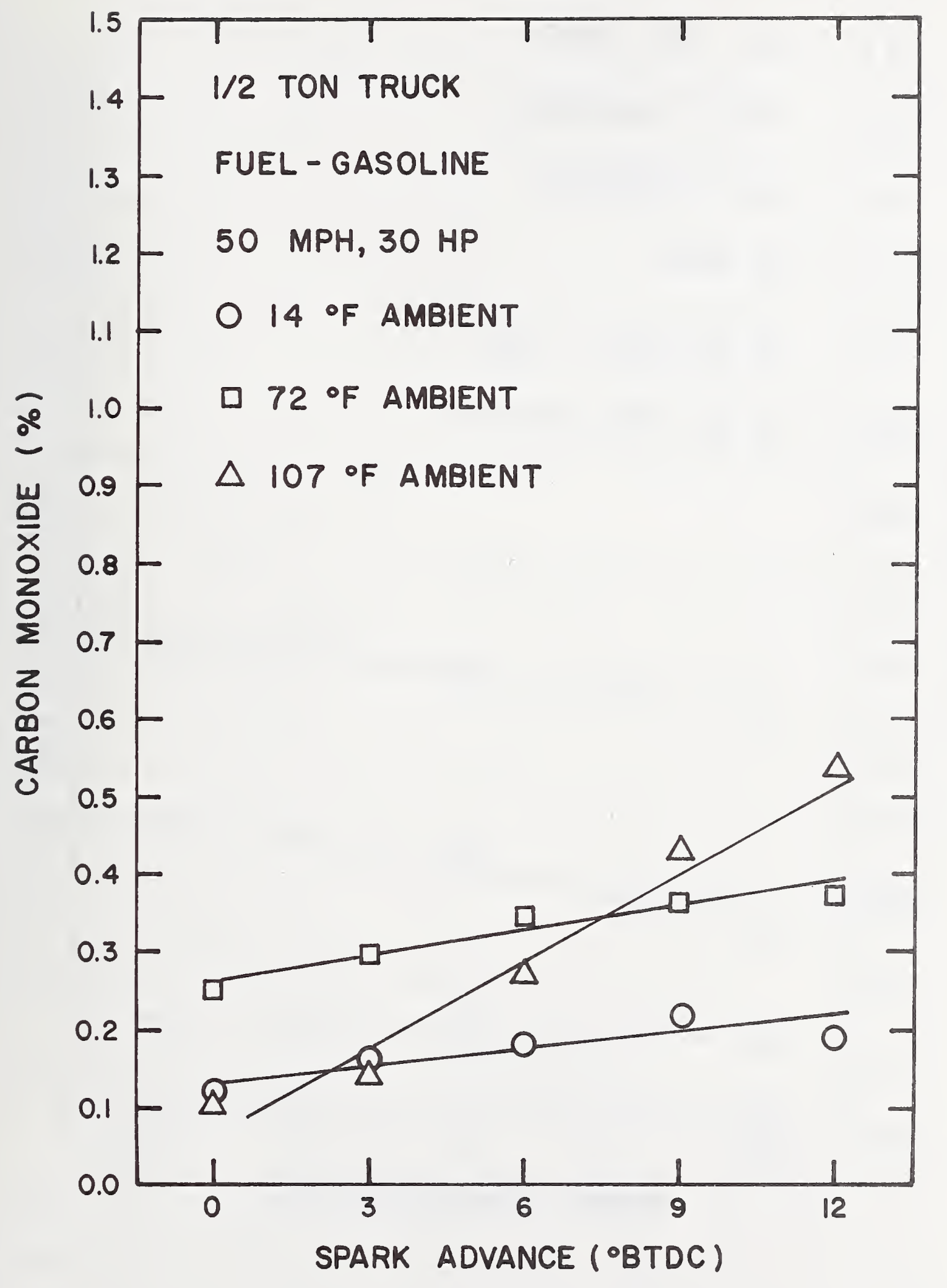

Figure 22 Carbon Monoxide Versus Spark Advance for a 1/2 Ton Truck Using Gasoline 


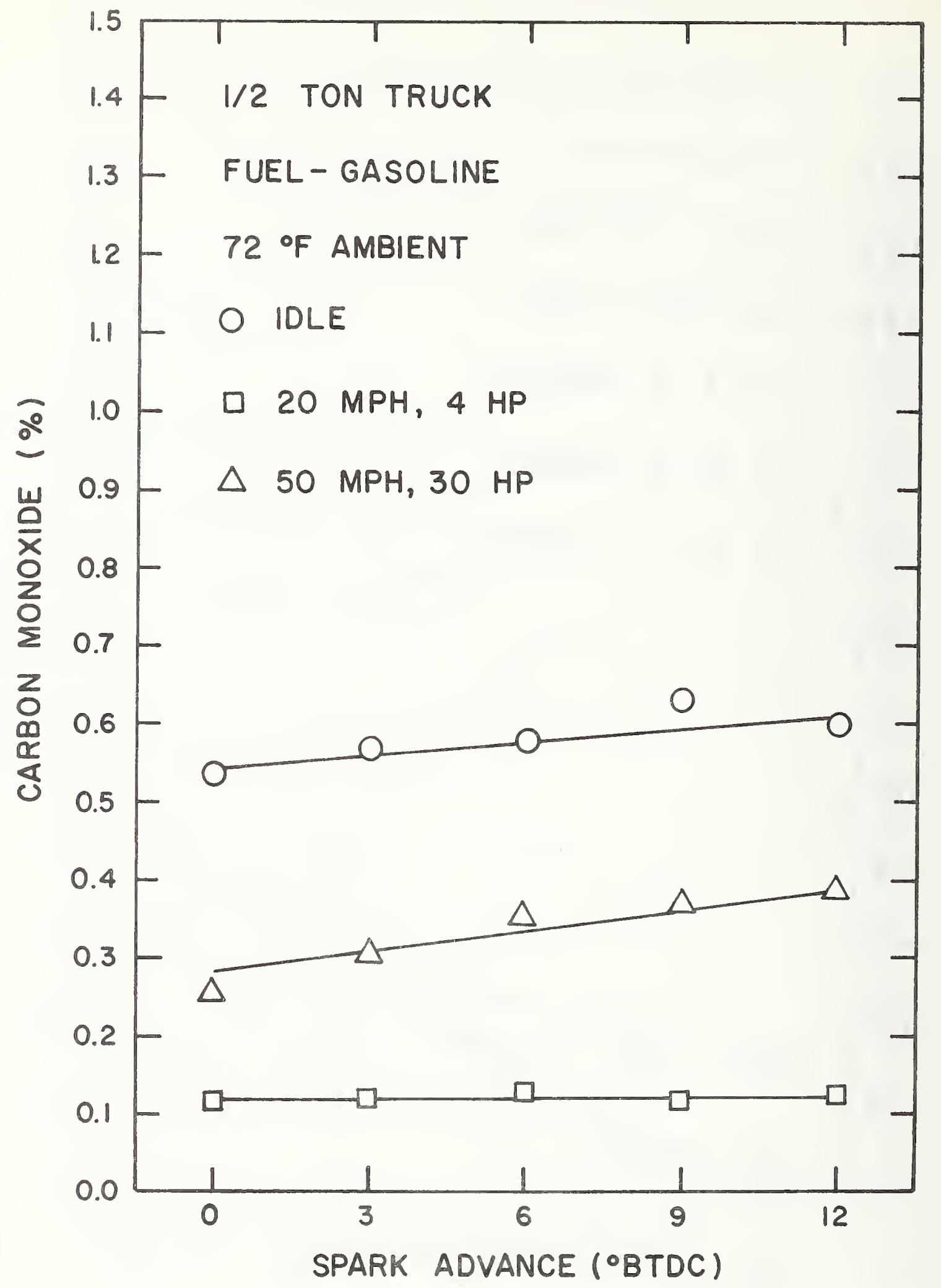

Figure 23 Carbon Monoxide Versus Spark Advance for a $1 / 2$ Ton Truck Using Gasoline 
The HC content is seen to have decreased as the vehicle was run faster and at higher loads (see Figure 18 and 20). The reason for this latter trend is probably two-fold: As engine speed increases, there is less time for quenching of the burning charge by the cool engine walls and the higher combustion temperatures at the higher loads promote more complete combustion.

Figure 21 shows that the co content was higher at iding conditions than at $20 \mathrm{mph}$ and $4 \mathrm{hp}$. However, there is no explanation for the fact that the pollutant was a minimum at $20 \mathrm{mph}$ and $4 \mathrm{hp}$ as compared to either idling conditions or 50 mph and 30 hp (Figure 23).

There appears to have been no constant dependence of pollutants on temperature. For example, Figures 15 and 16 show that the $\mathrm{NO}_{\mathrm{x}}$ concentration was slightly higher at the lower ambient temperature and Figures 18 and 19 show the opposite trend for the hydrocarbons. The difficulty in making any general statement concerning temperature is that the tests were conducted in such a way that the effect that temperature had on the carburetion could not be distinguished from the dependence of pollutant formation on temperature.

4.2 Compressed Natural Gas-Fueled Tests

4.2.1 Spark Advance as the Independent Variable

Figures 24 through 28 are for tests at $75^{\circ} \mathrm{F}$ where the idle spark advance was the independent parameter. Figure 24 shows again (as in the case of the gasoline tests) the way in which $\mathrm{NO}_{\mathrm{x}}$ concentration increased as the spark was advanced. Data 


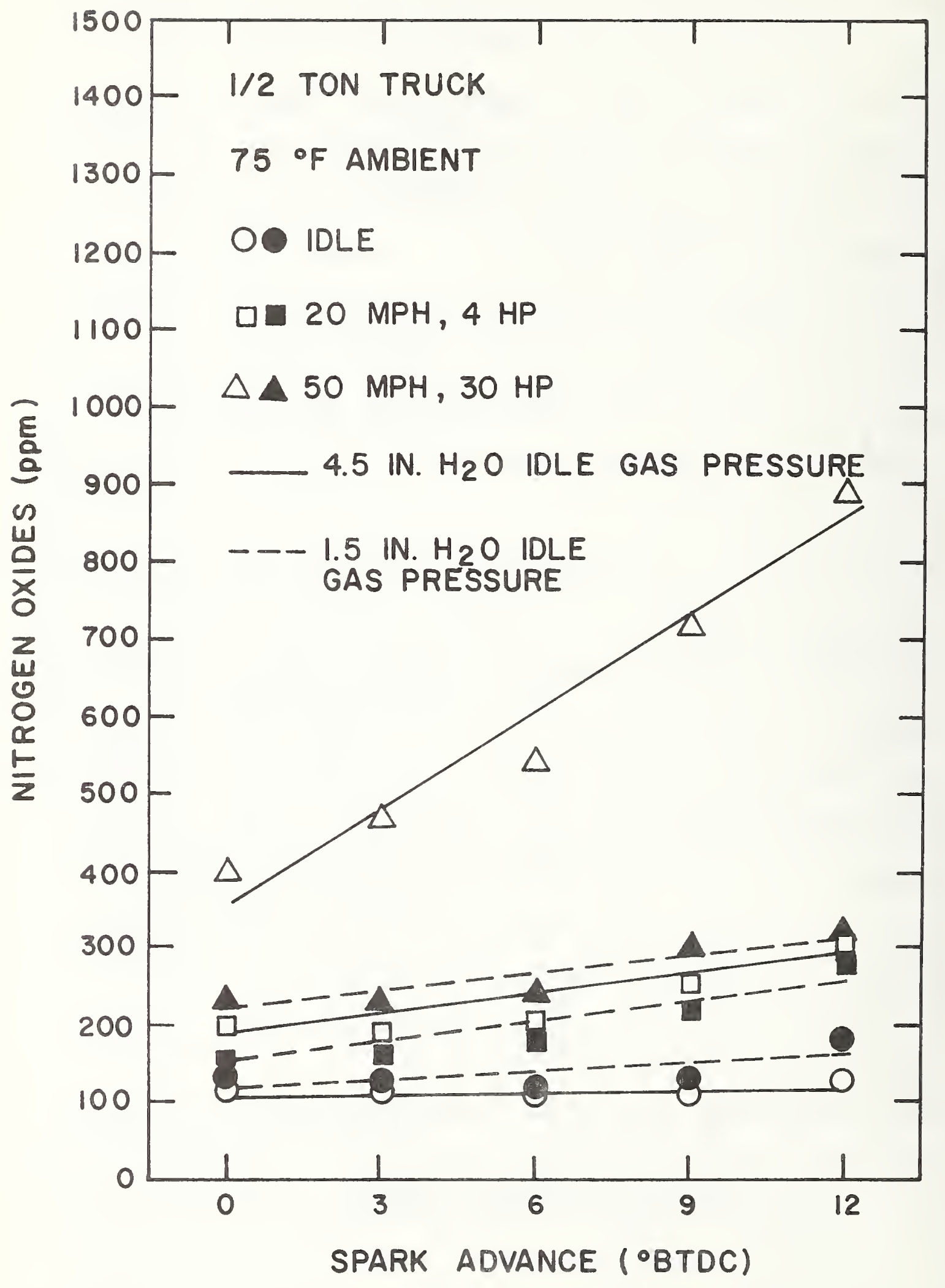

Figure 24 Nitrogen Oxides Versus Spark Advance for a $1 / 2$ Ton Truck Using CiNG 
is shown for 3 running conditions (idle, $20 \mathrm{mph}$ and $4 \mathrm{hp}, 50$ $\mathrm{mph}$ and $30 \mathrm{hp})$ at 1.5 in. $\mathrm{H}_{2} \mathrm{O}$ and $4.5 \mathrm{in} . \mathrm{H}_{2} \mathrm{O}$ idle gas pressure (igp). At the two running speeds, the $\mathrm{NO}_{\mathrm{x}}$ was higher for the 4.5 in. $\mathrm{H}_{2} \mathrm{O}$ igp tests than for the 1.5 in. $\mathrm{H}_{2} \mathrm{O}$ igp tests. This is to be expected since the mixtures should be richer at the higher gas pressures (which is verified in Figure 27). The reverse was true at idling conditions and as can be seen from Figure 27, the mixture was richer at the lower iding gas pressure. The very large difference in No ${ }_{x}$ concentration between 1.5 in. $\mathrm{H}_{2} \mathrm{O}$ igp and 4.5 in. $\mathrm{H}_{2} \mathrm{O}$ igp at the high speed and load can again be explained by the large difference in $A / F$ ratio that resulted (Figure 27).*

Figures 25 and 26 show the HC and CO variation with spark advance and running conditions at 1.5 in. $\mathrm{H}_{2} \mathrm{O}$ igp and 4.5 in. $\|_{2} 0$ igp respectively. The data variation with speed and spark advance is consistent with previous explanations with the exception of the Co data at idle and 1.5 in. $\mathrm{H}_{2} 0$ igp. The increase with spark advance would not have occurred had the air-fuel ratio remained rixed at 18 or 19 . However, as shown in Figure 27, the mixture became rich as the spark was advanced, thus causing the unusual trend.

Besides giving insight into unusual data behavior, Figure 27 illustrates that although determination of the variation of pollutants with idle spark advance was the primary goal of

\footnotetext{
* As the mixture is enriched toward stoichiometric conditions, $\mathrm{NO}_{\mathrm{X}}$ increases as will be explained in section 4.2.2
} 


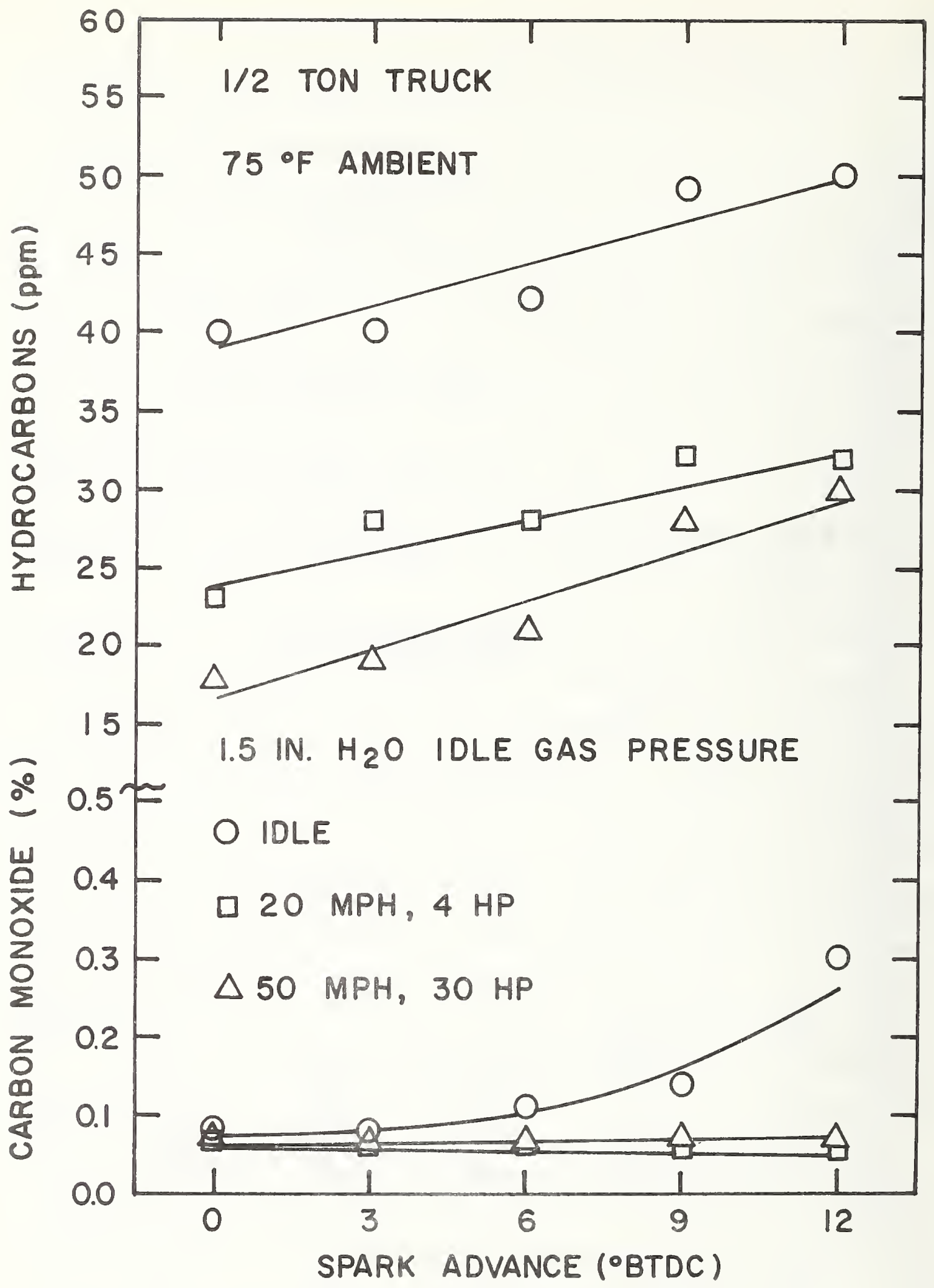

Figure 25 Hydrocarbons and Carbon Monoxide Versus Spark Advance for a $1 / 2$ Ton Truck using CNG 


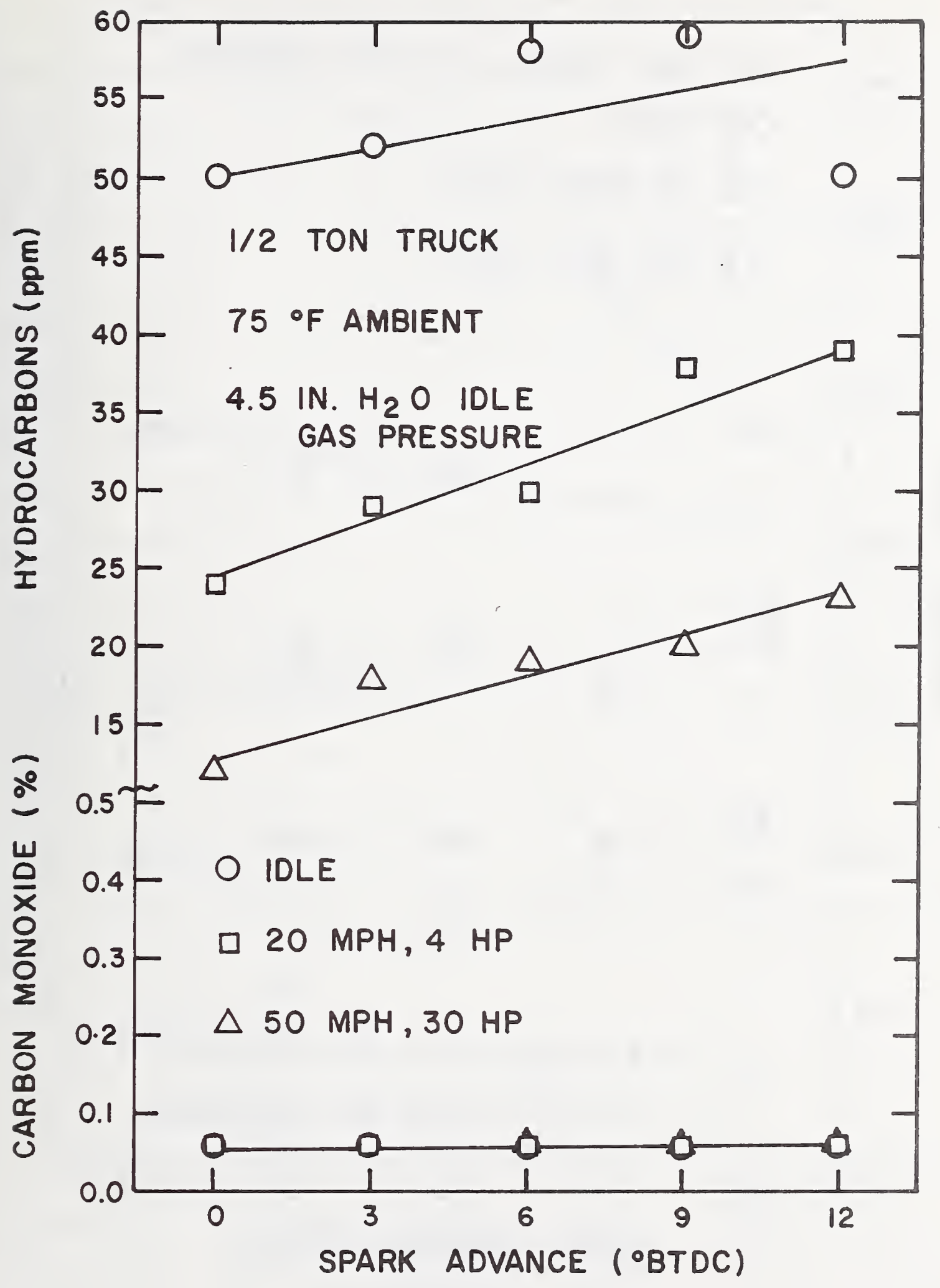

Figure 26 Hydrocarbons and Carbon Monoxide Versus Spark Advance for a $1 / 2$ Ton Truck Using CNG 


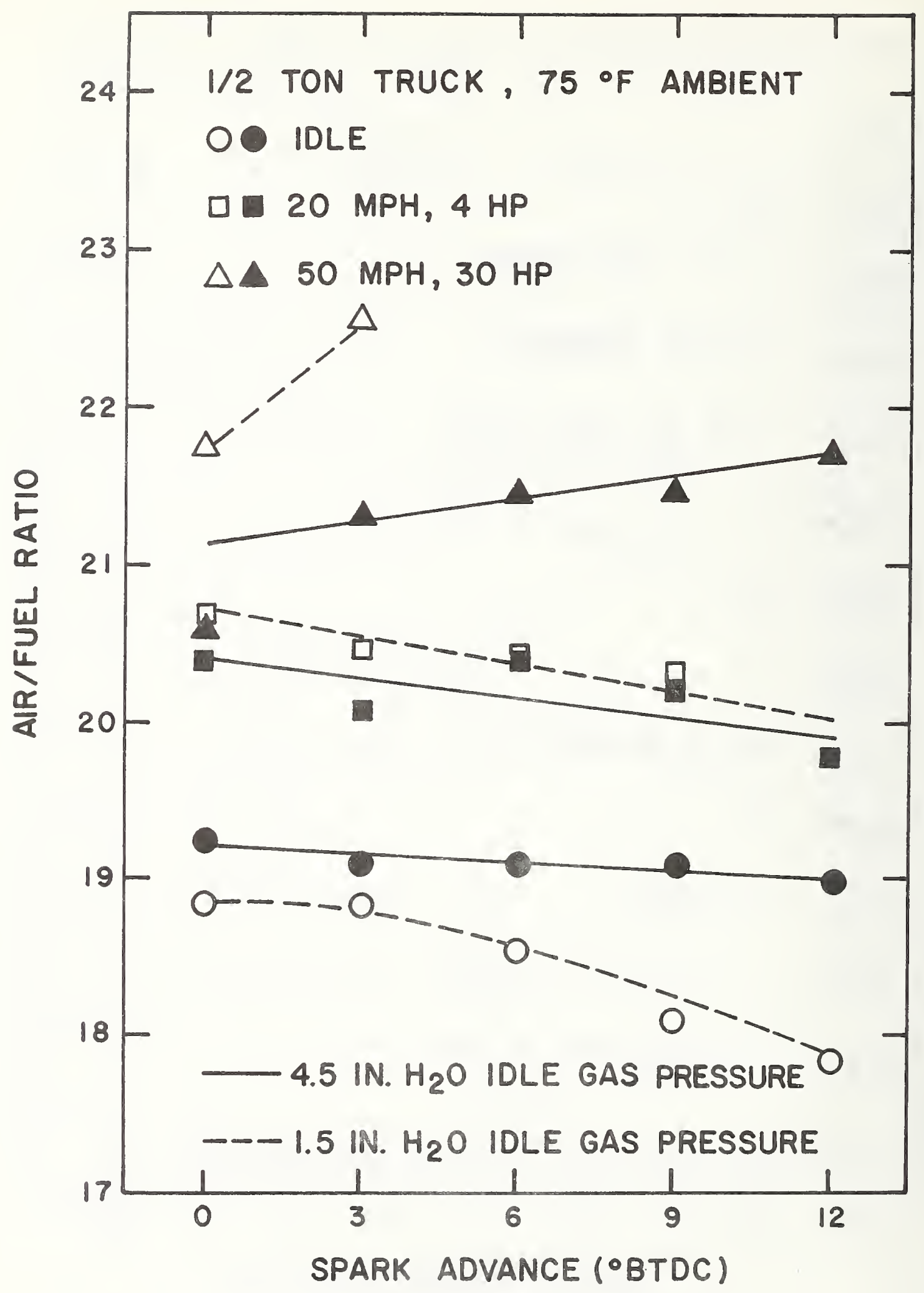

Figure 27 Air-Fuel Ratio Versus Spark Advance for a $1 / 2$ Ton Truck Using CNG 
these tests, air-fuel ratio could not simultaneously be held fixed during the tests because no direct measurements or control of it was practical. Figure 28 shows that there was only slight (if any) gas pressure variation during any one test. The change in air-fuel ratio that resulted in some cases was then caused by other than the fuel supply regulation system.

Figures 29 through 33 are results of CNG-fired spark advance tests at $108^{\circ} \mathrm{F}$ similar to those done at $75^{\circ} \mathrm{F}$. As with the previous CNG tests and the gasoline tests, $N_{x}$ increased with increasing spark advance and speed, HC increased with increasing spark advance and decreasing speed and co remained practically constant with spark advance and speed. The airfue 1 ratio that resulted in each test is shown in Figure 32 and the very slight variation of gas pressure with spark advance shown in Figure 33. Although there is only one data point shown in Figure 32 for the $50 \mathrm{mph} / 30 \mathrm{hp}$ test at an idle gas pressure of 1.5 in. $\mathrm{H}_{2} 0$, a line was drawn indicating the probable dependence on spark advance (based on measurements and calculations of air-fuel ratio completely off scale of Figure 32).

4.2.2 Air-Fue1 Ratio as the Independent Variable

Figures 34 through 41 show the results of tests conducted at approximate $1 y \quad 75^{\circ} \mathrm{F}$ with the vehicle running on compressed natural gas. This is the first of a series of results showing the effect air-fuel ratio has on the various pollutants. 


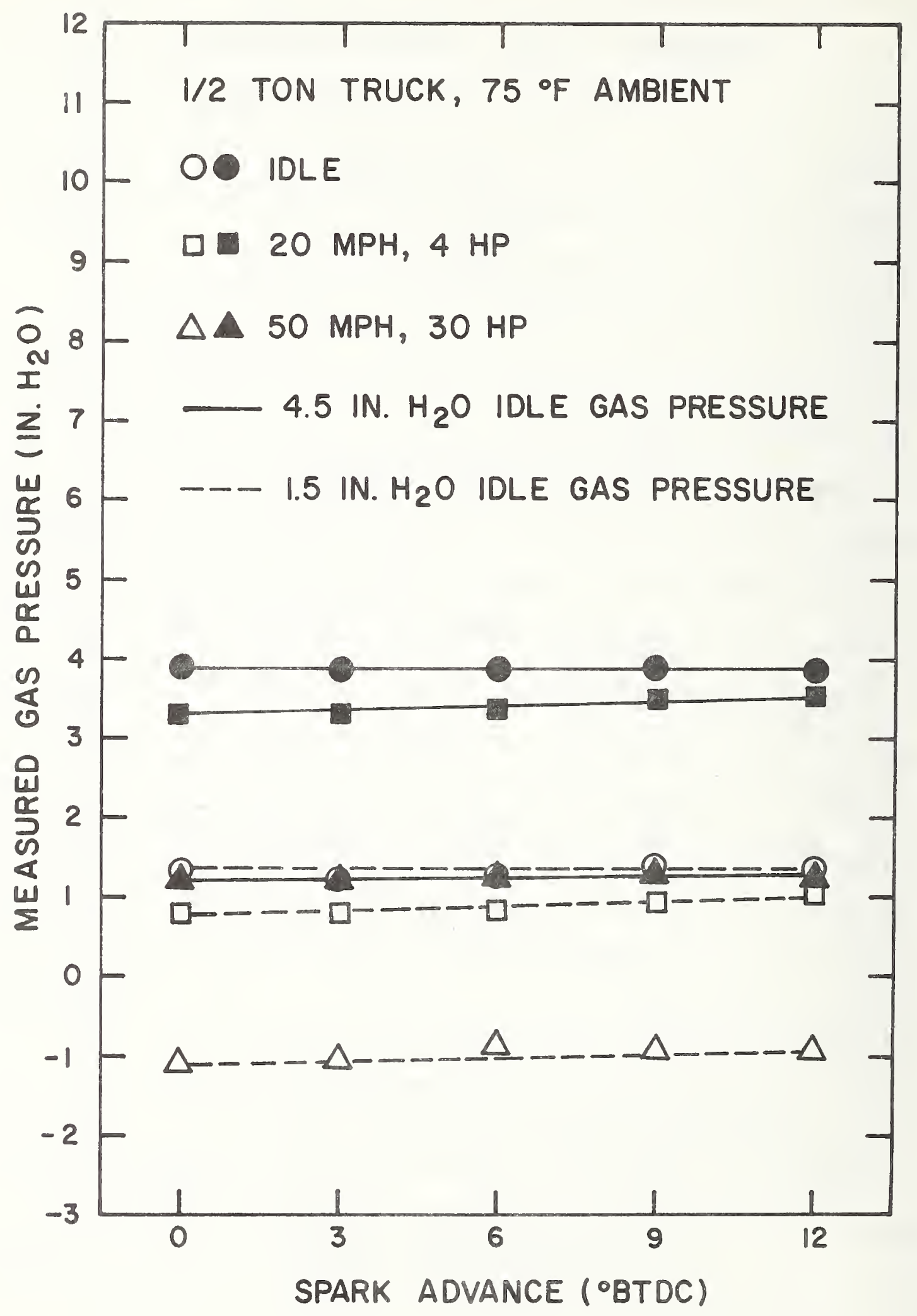

Figure 28 Gas Pressure at Running Conditions Versus Spark Advance for a $1 / 2$ Ton Truck Using CNG 


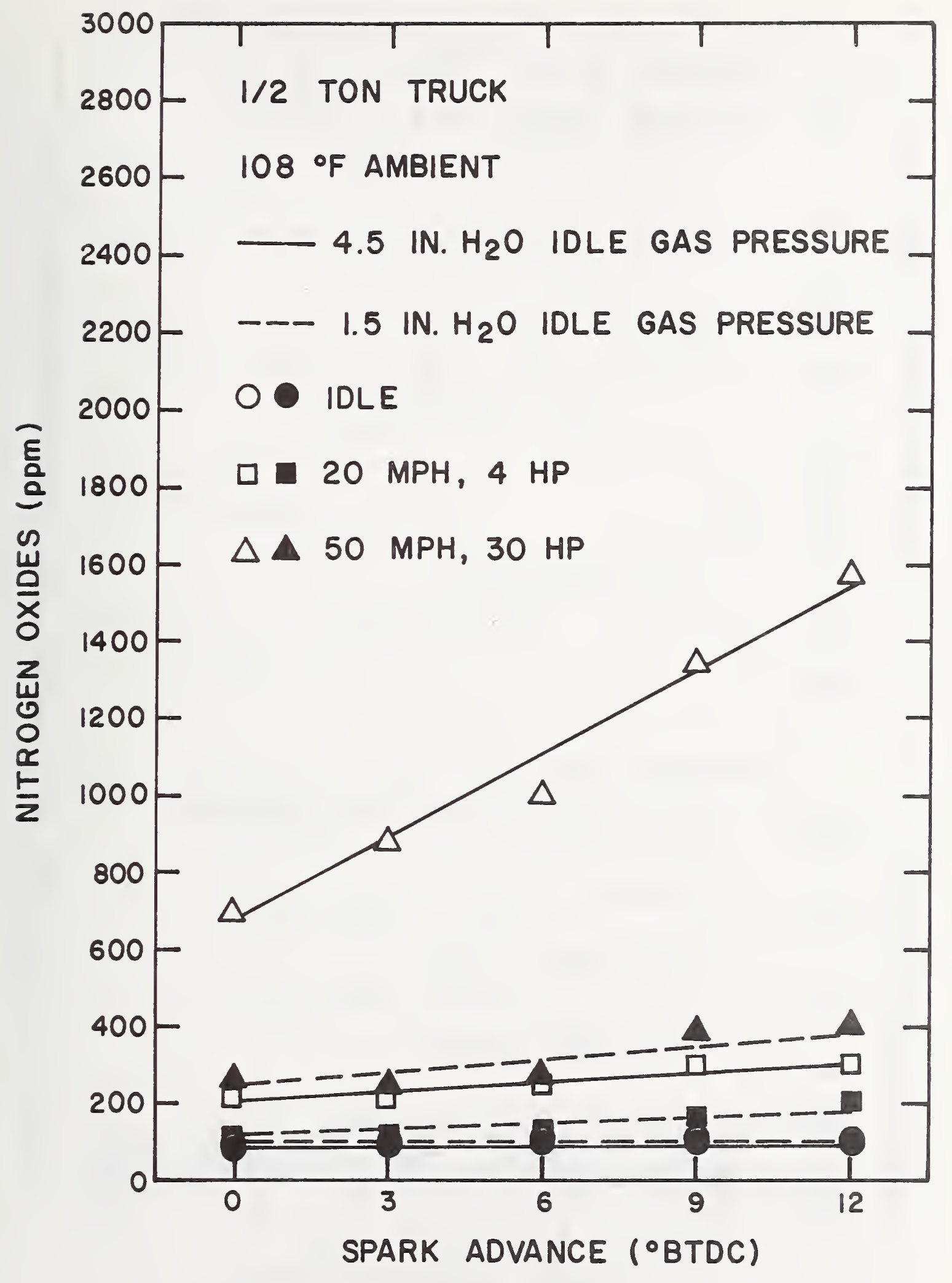

Figure 29 Nitrogen Oxides Versus Spark Advance for a $1 / 2$ Ton Truck Using CNG 


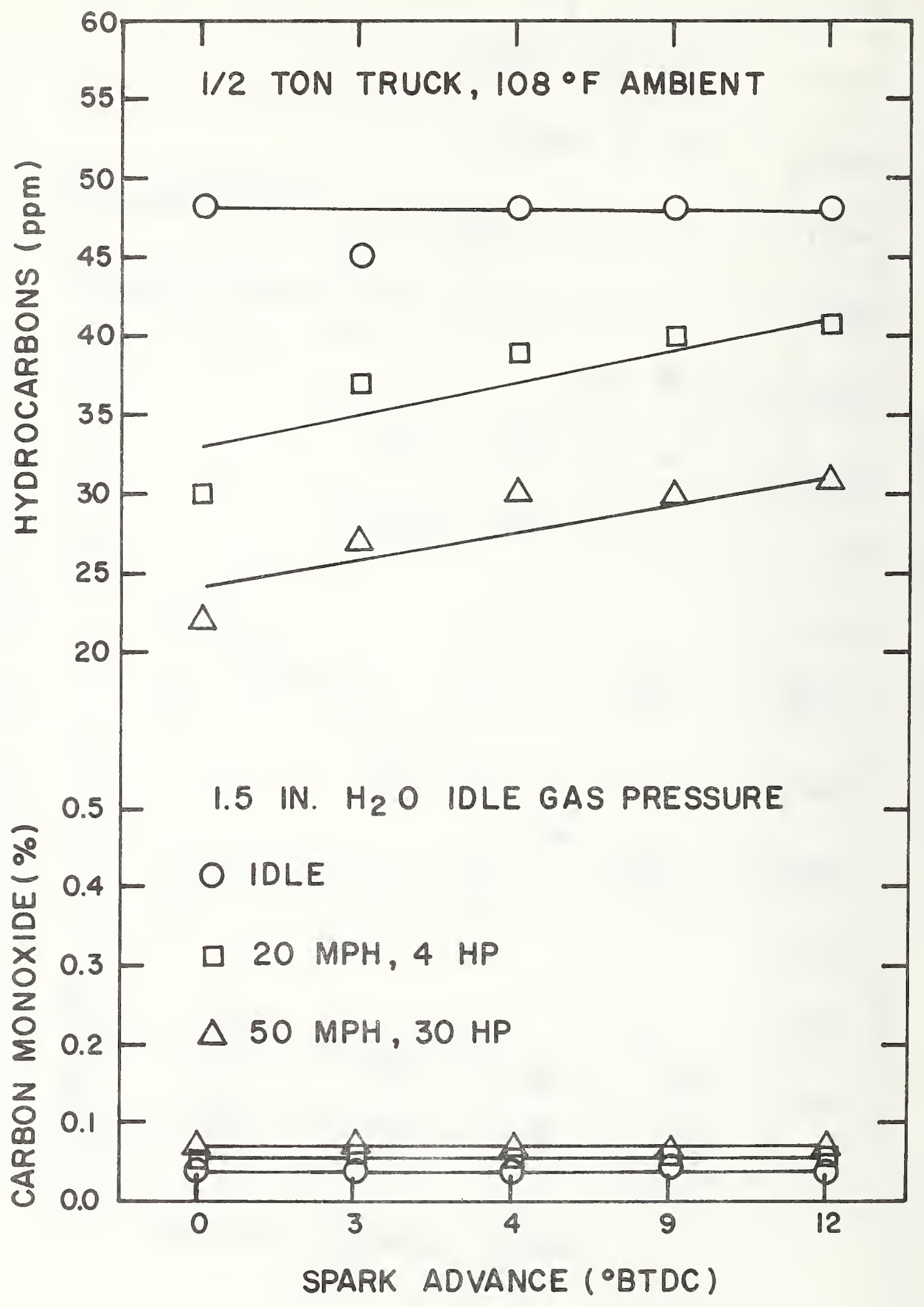

Figure 30 Hydrocarbons and Carbon Monoxide Versus Spark Advance for a $1 / 2$ Ton Truck Using CNG 


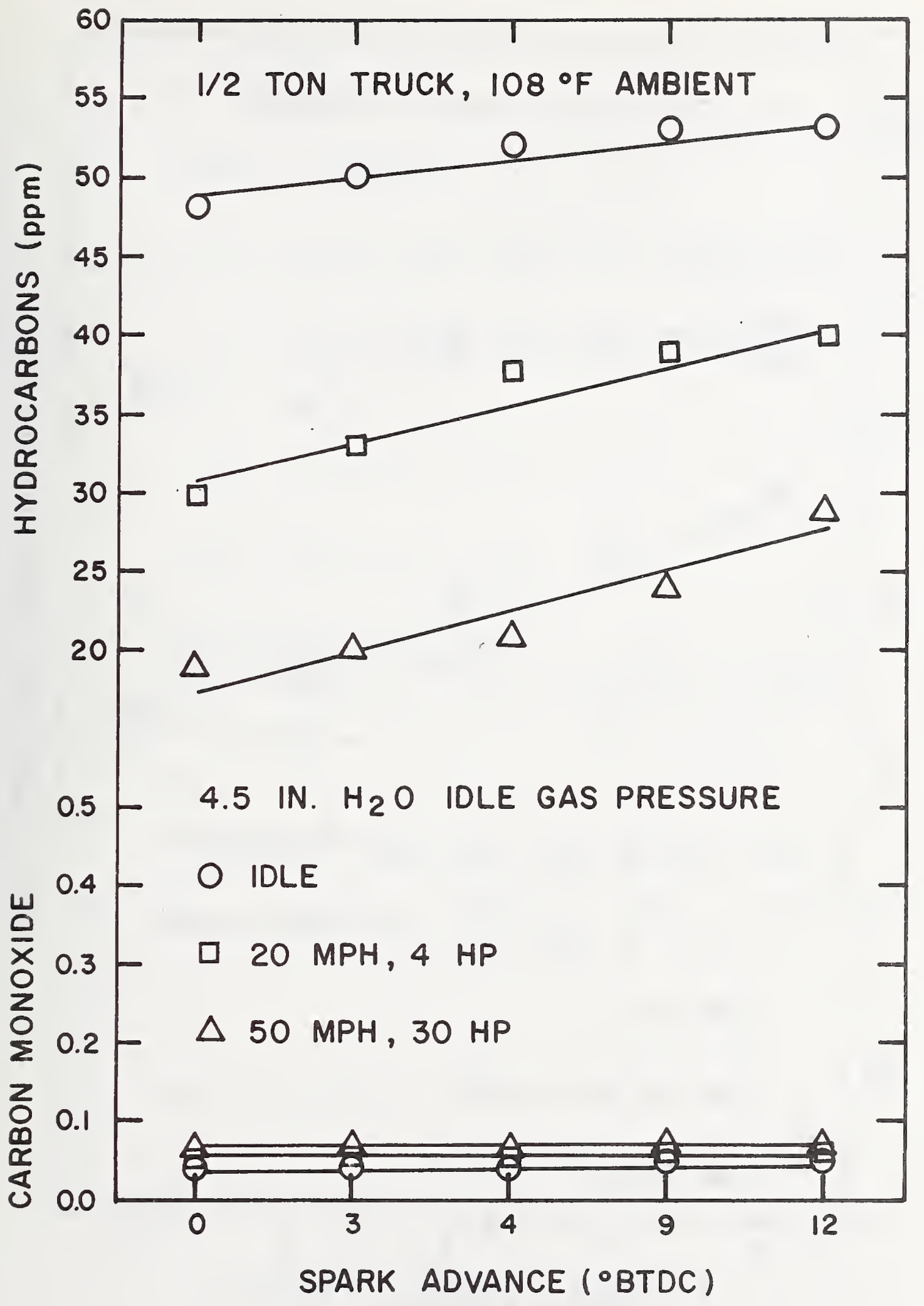

Figure 31 Hydrocarbons and Carbon Monoxide Versus Spark Advance for a $1 / 2$ Ton Truck Using CNG 


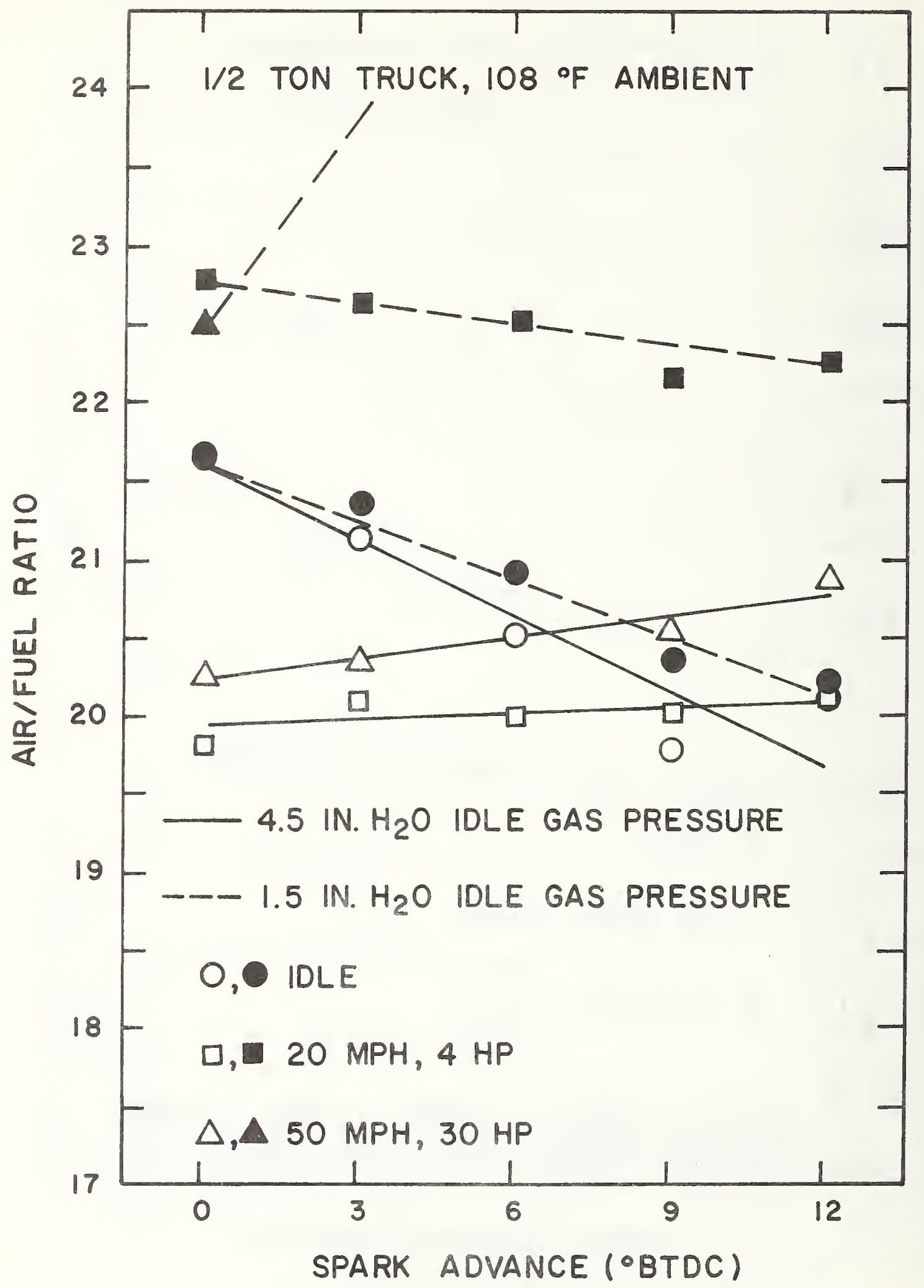

Figure 32 Air-Fuel Ratio Versus Spark Advance for a $1 / 2$ Ton Truck Using CNG 


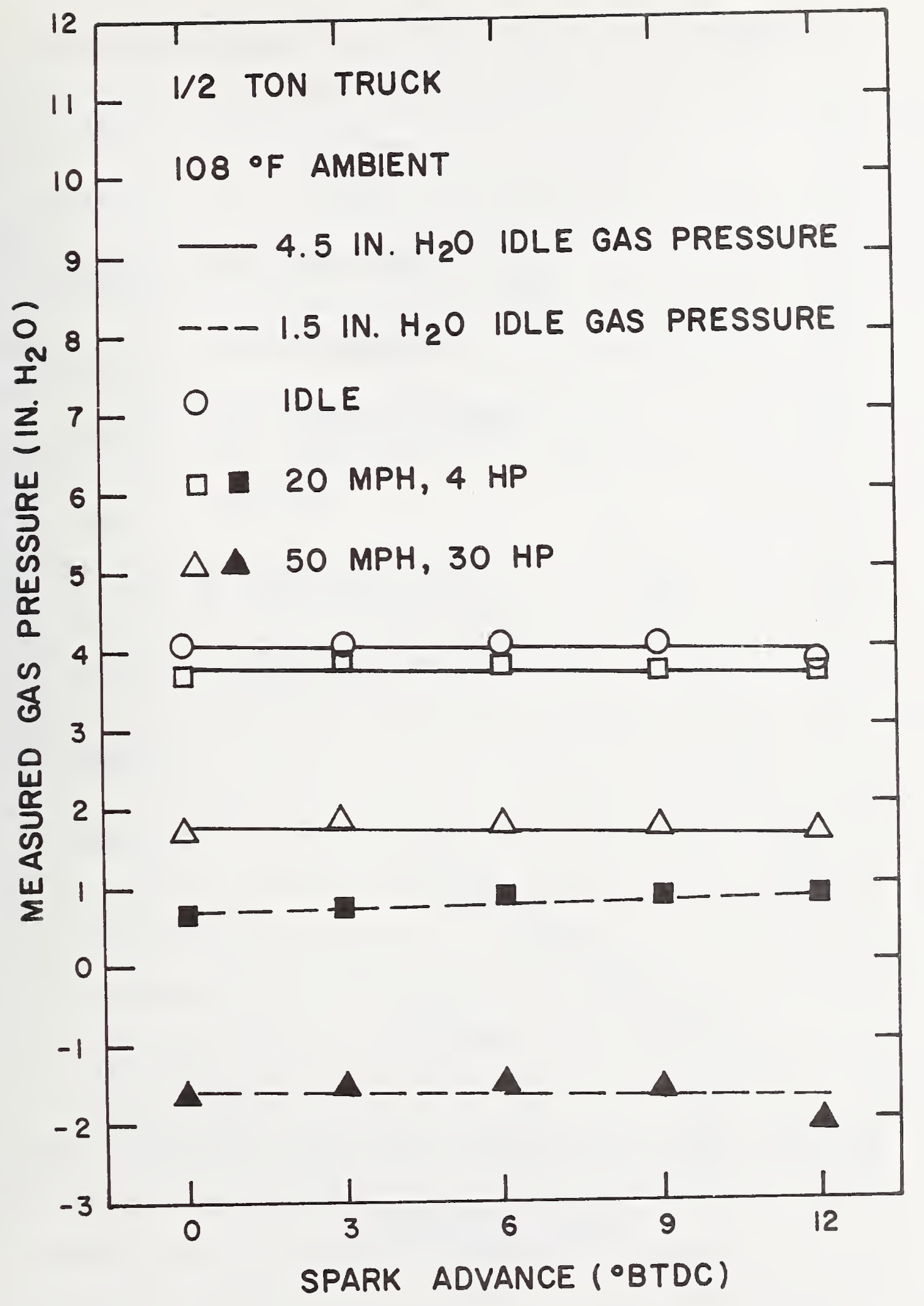

Figure 33 Gas Pressure at Running Conditions Versus Spark Advance for a $1 / 2$ Ton Truck Using CNG 
The change in $\mathrm{NO}_{\mathrm{x}}$ as air-fuel ratio changes (Figure 34 ) results from the way in which air-fuel ratio affects the peak temperature. As the ratio is increased from a very rich condition towards a stoichiometric one $(A / F=17.24)$, more complete combustion results thus increasing the maximum chamber temperature that occurs. However, once beyond a condition in the vicinity of theoretical air, the excess air slows the speed of the flame as it sweeps across the combustion chamber. Consequent1y, the peak temperature decreases as the mixture is made more lean.

Figure 35 shows the way in which HC and CO varied with the air-fuel ratio. Once beyond stoichiometric conditions in the direction of a leaner mixture, sufficient oxygen existed for nearly complete combustion. Therefore, the effect of a change in the air-fuel ratio to a leaner mixture had practically no effect on the CO or HC content. The one data point in Figure 35 at an A/F ratio less than 17, shows how the hydrocarbon content increases as a result of insufficient air and incomplete combustion. Figures 36 and 37 show the same data only at several values of idling spark setting. The dependence on spark advance was the same as already noted. Figures 38 and 39 give data that was obtained by running the vehicle at $20 \mathrm{mph}$ and maximum load so that the throttle was wide open. The amount of horsepower obtained and pollutants that resulted can be seen. This test data serves to show that the changes that obviously give the higher peak temperatures 


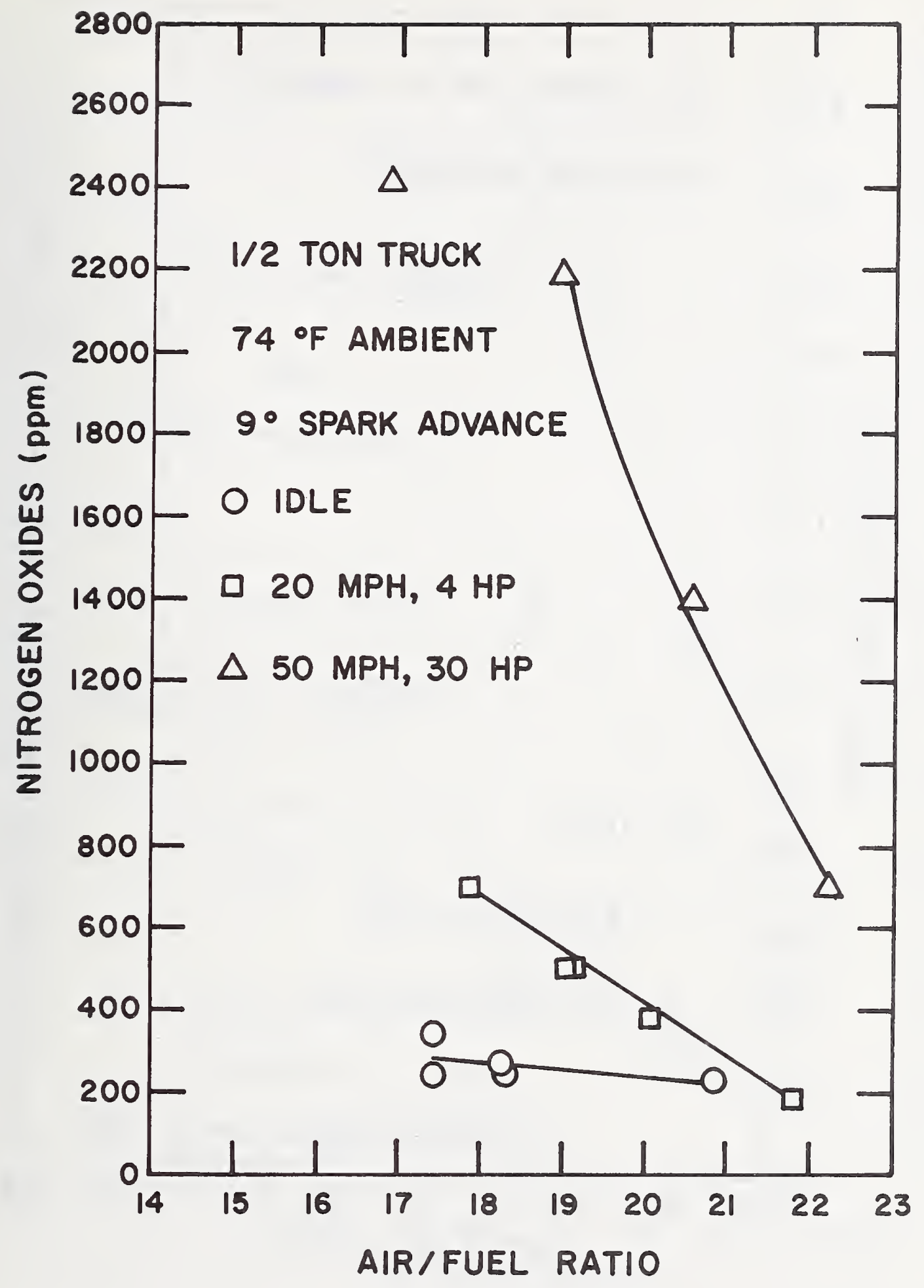

Figure 34 Nitrogen Oxides Versus Air-Fuel Ratio for a $1 / 2$ Ton Truck Using CNG 


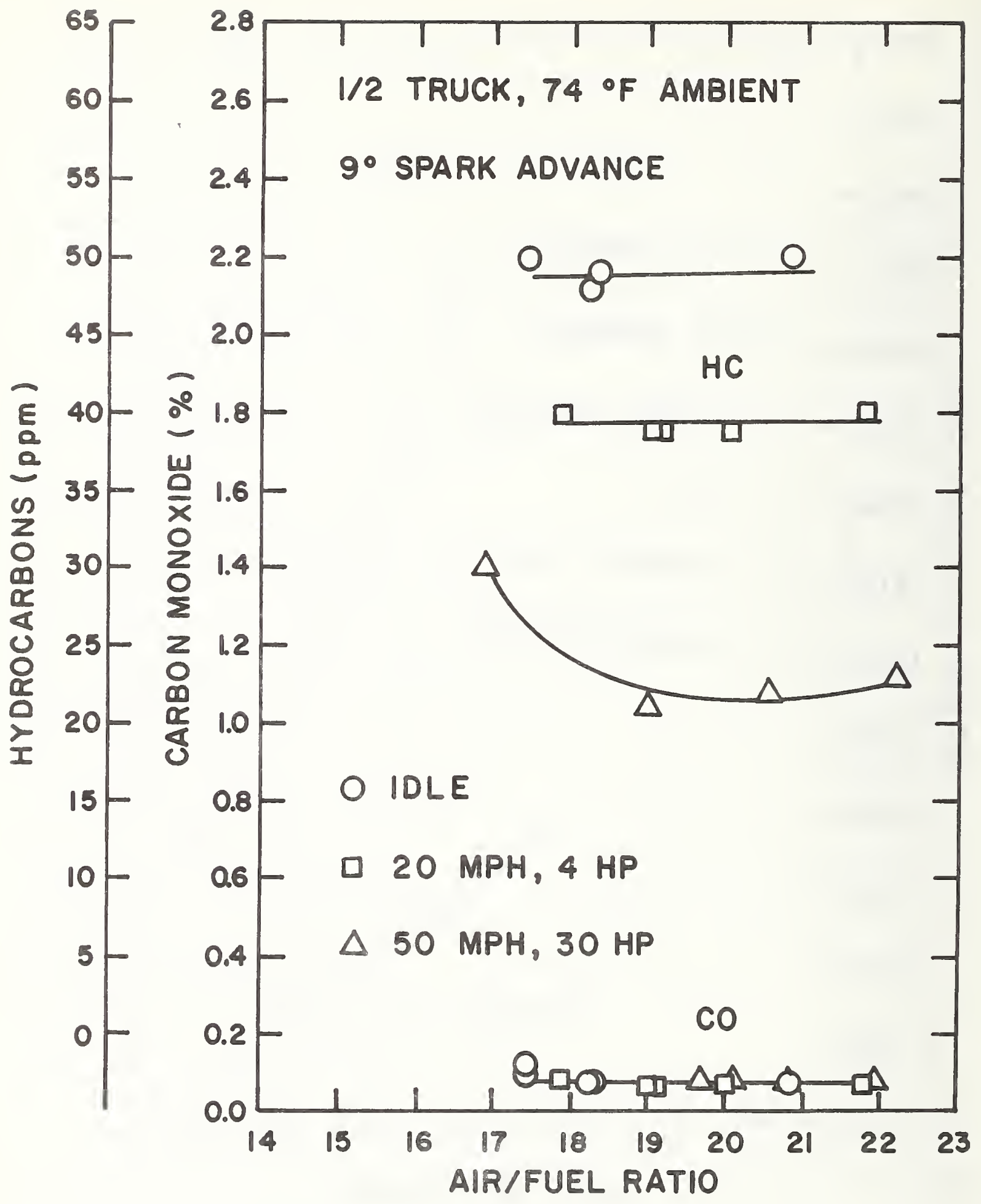

Figure 35 Hydrocarbons and Carbon Monoxide Versus Air-Fue 1 Ratio for a $1 / 2$ Ton Truck Using CNG 


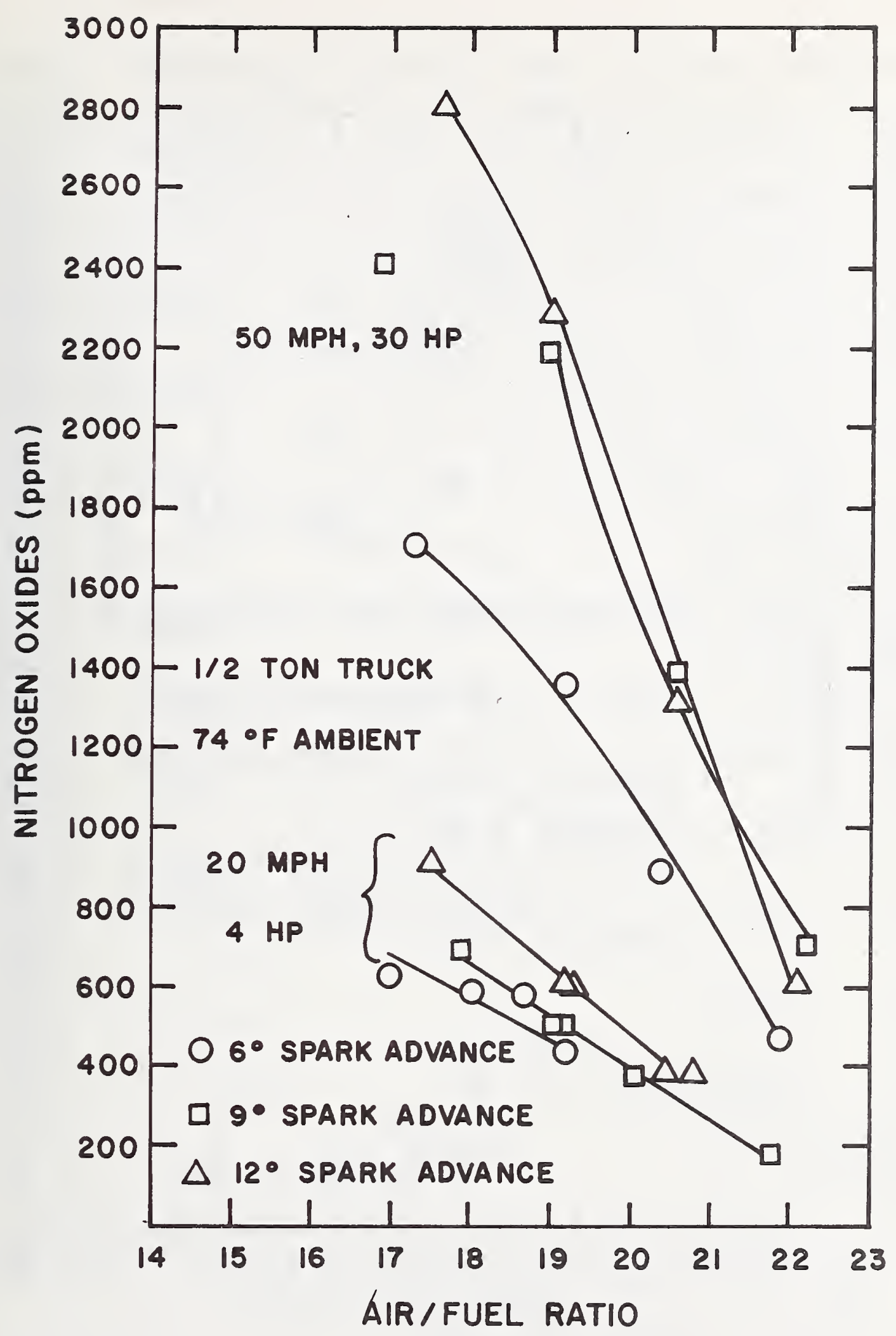

Figure 36 Nitrogen oxides Versus Air-Fuel Ratio for a $1 / 2$ Ton Truck Using CNG 


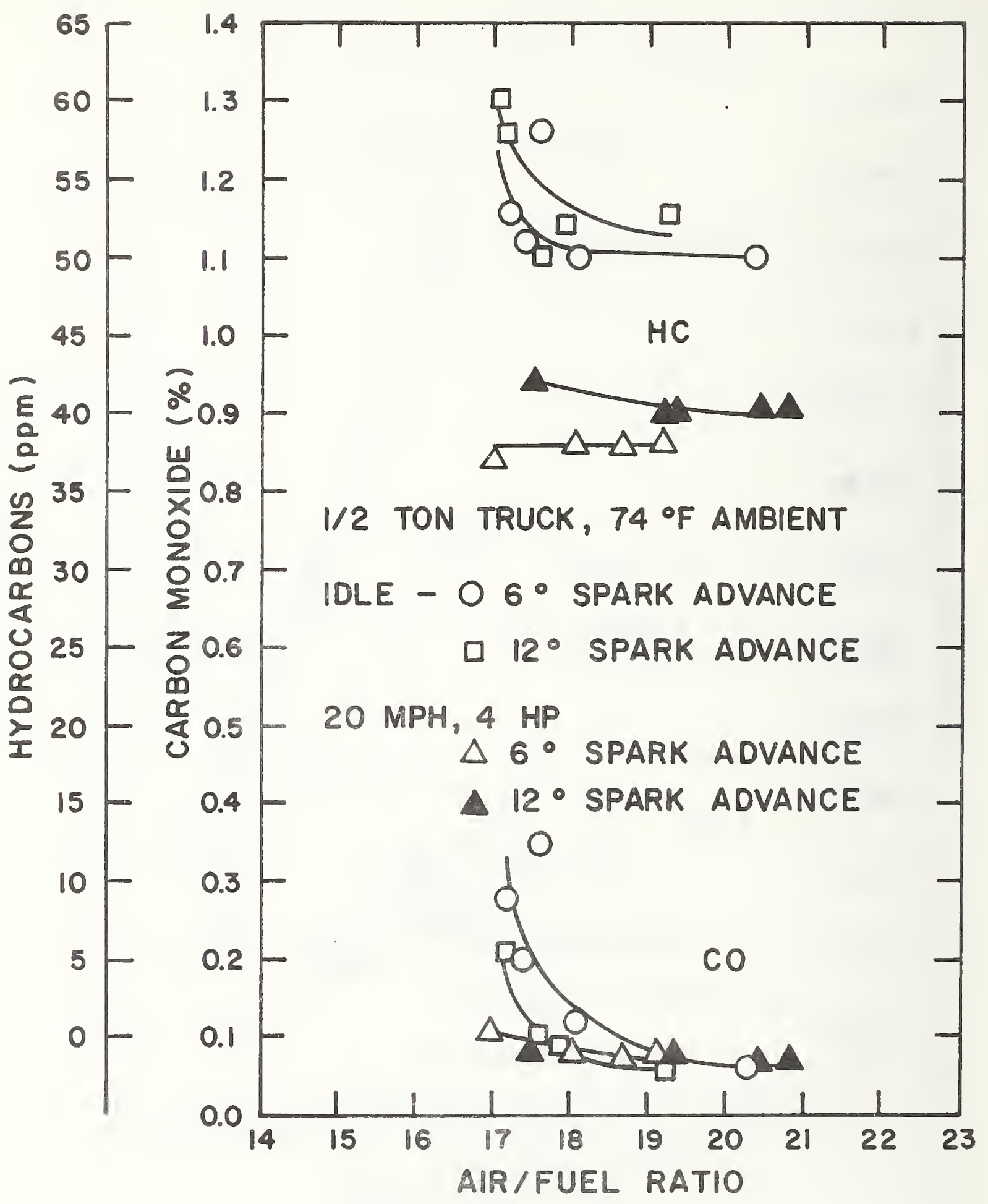

Figure 37 Hydrocarbons and Carbon Monoxide Versus Air-Fue 1 Ratio for a $1 / 2$ Ton Truck Using CNG 


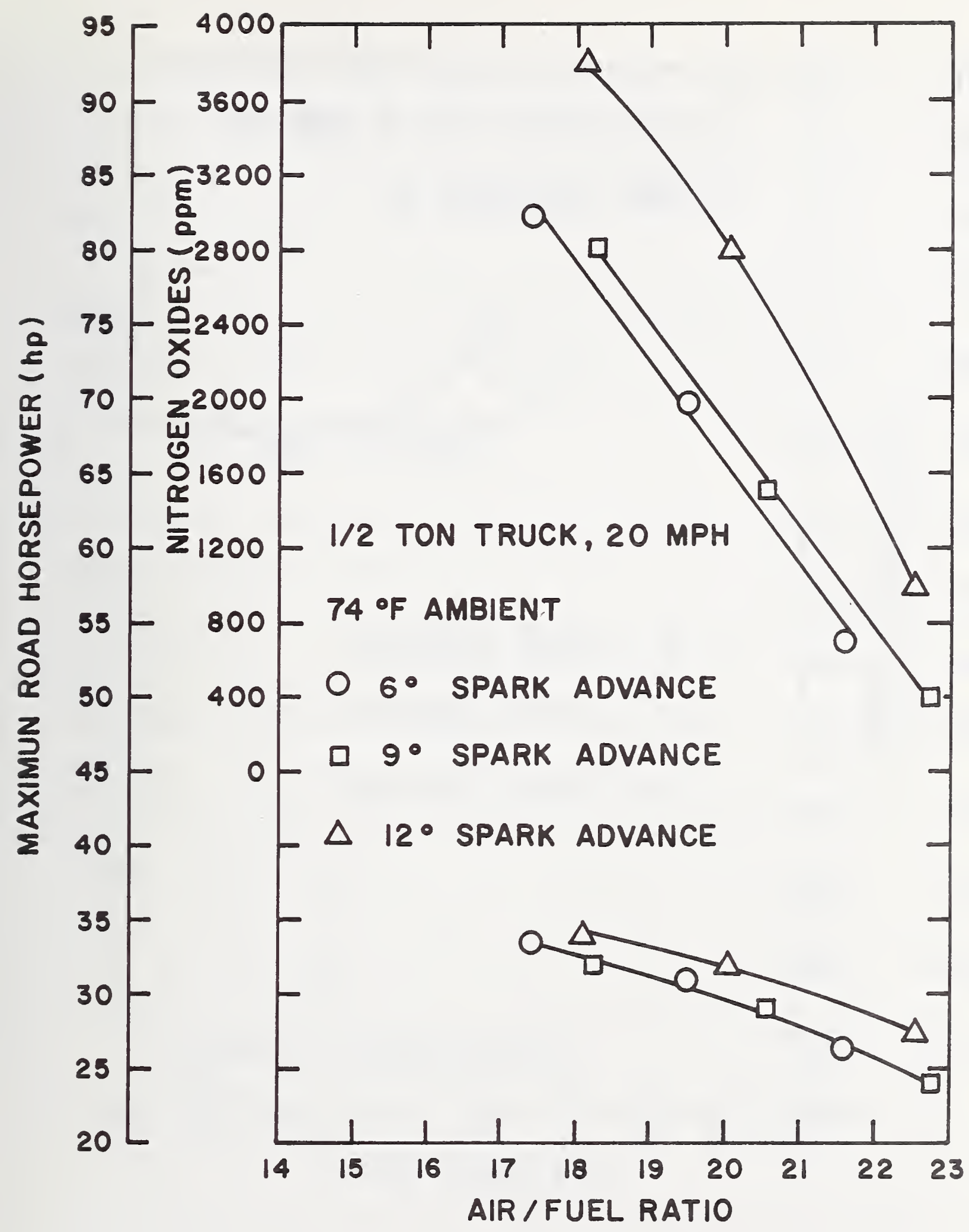

Figure 38 Maximum Horsepower and Nitrogen oxides Versus AirFuel Ratio for a $1 / 2$ Ton Truck Using $C N G$ and Operating at Full Throttle 


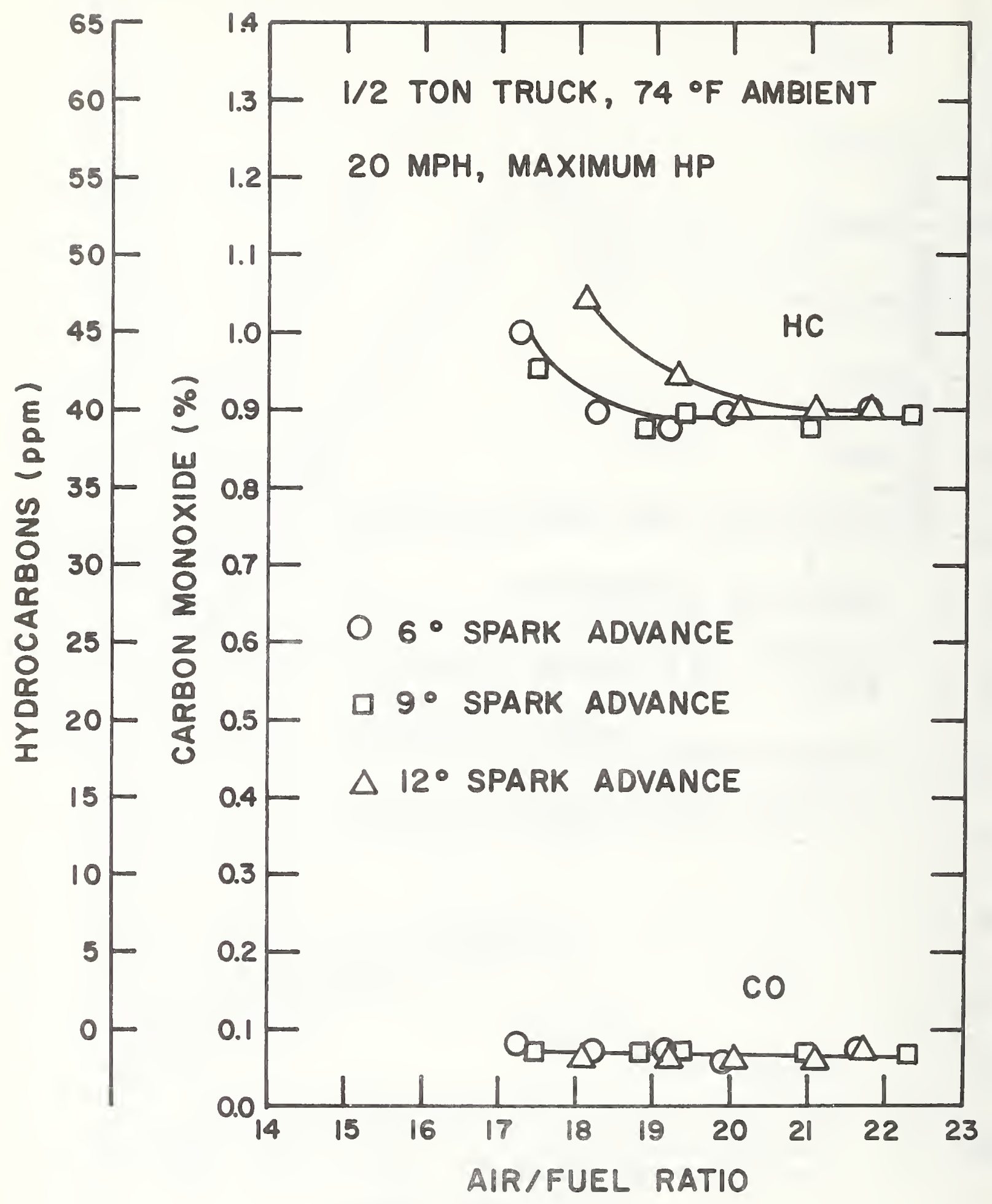

Figure 39 Hydrocarbons and Carbon Monoxide Versus Air-Fue 1 Ratio for a $1 / 2$ Ton Truck Using CNG and Operating at Ful1 Throtte 
in the cylinders (advancing the spark from $6^{\circ}$ to $12^{\circ}$ before top-dead-center, and an air-fuel ratio closer to the stoichiometric condition) also correspond to changes that result in more power output.

By observing the curves discussed up to this point, it should be clear that more significant results in pollutant reduction can be obtained by emphasizing the settings to give a proper air-fuel ratio than by emphasizing the spark setting. Figure 40 is particularly important in that it shows the way in which the air-mixer and associated controls in the CNG gas system affected a change in the air-fuel ratio as the vehicle was run faster and loaded down. For example, if the gas pressure were adjusted to 2 in. $\mathrm{H}_{2} 0$ at idling conditions $(550 \mathrm{rpm})$ and the tweeker adjusted as lean as possible (and yet a good idling obtained), the A/F ratio on the vehicle tested would be approximately 18. This is leaner than stoichiometric thus giving complete combustion with a minimum of $\mathrm{CO}$ and $\mathrm{HC}$. If the truck were run faster and loaded down, it has already been noted that with a constant air-fuel ratio, the HC would increase, CO remain the same, and $\mathrm{NO}_{\mathrm{x}}$ increase tremendously. However, as can be seen in the actual system, the A/F decreased ultimately to about $221 / 2$ at $50 \mathrm{mph}$ and $30 \mathrm{hp}$. This caused a certain loss in available power; however, the vehicle tested still produced $30 \mathrm{hp}$ and in addition, the $\mathrm{NO}_{\mathrm{x}}$ was only $600 \mathrm{ppm}$. The table below indicates the resulting pollutants for a 2 in. 


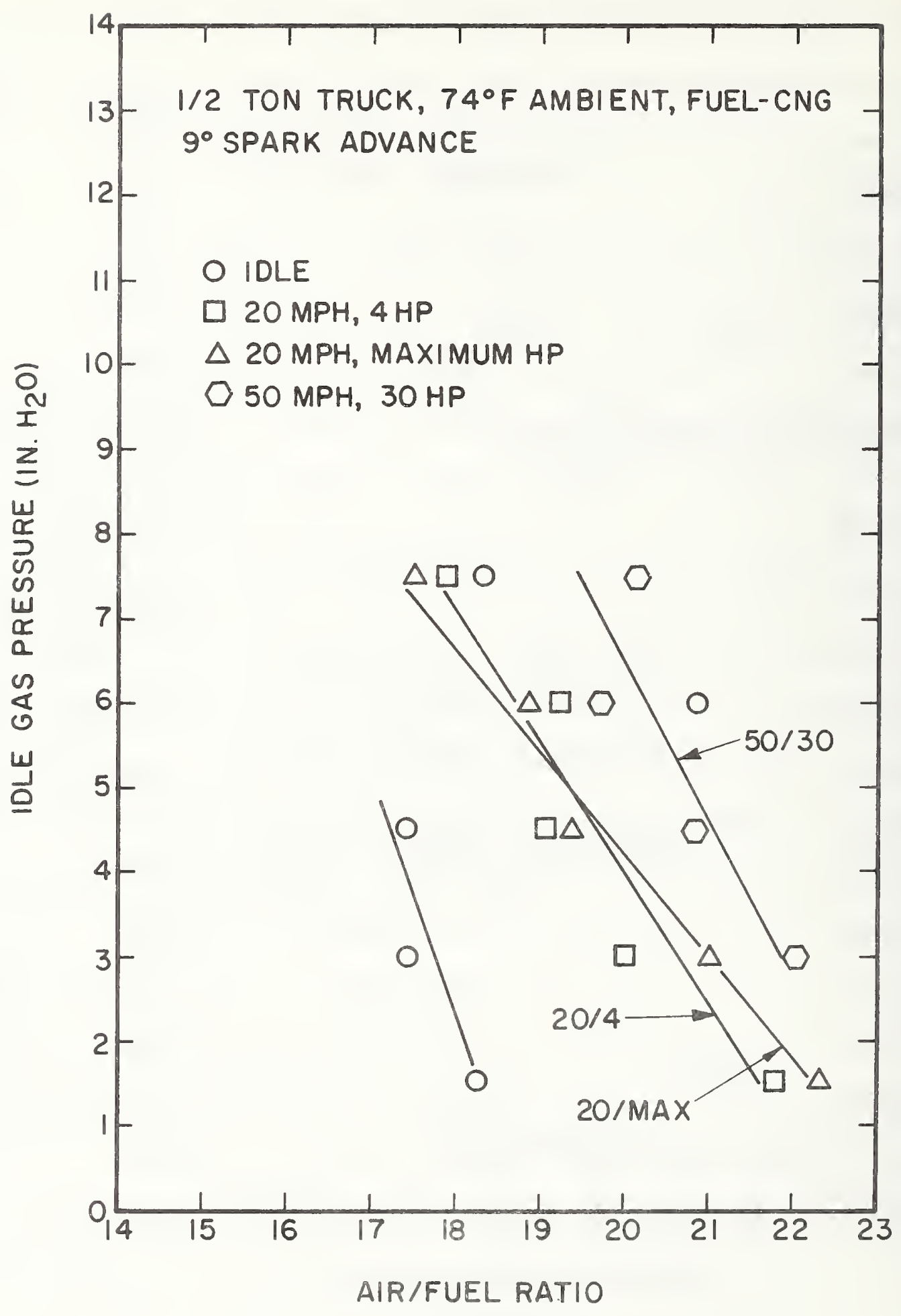

Figure 40 Idle Gas Pressure Versus Air-Fuel Ratio for a $1 / 2$ Ton Truck Using CNG 
$\mathrm{H}_{2} \mathrm{O}$ idle gas pressure setting and three running conditions due to the PALCO* system operation.

Table 1 Characteristics of PALCo System Operation

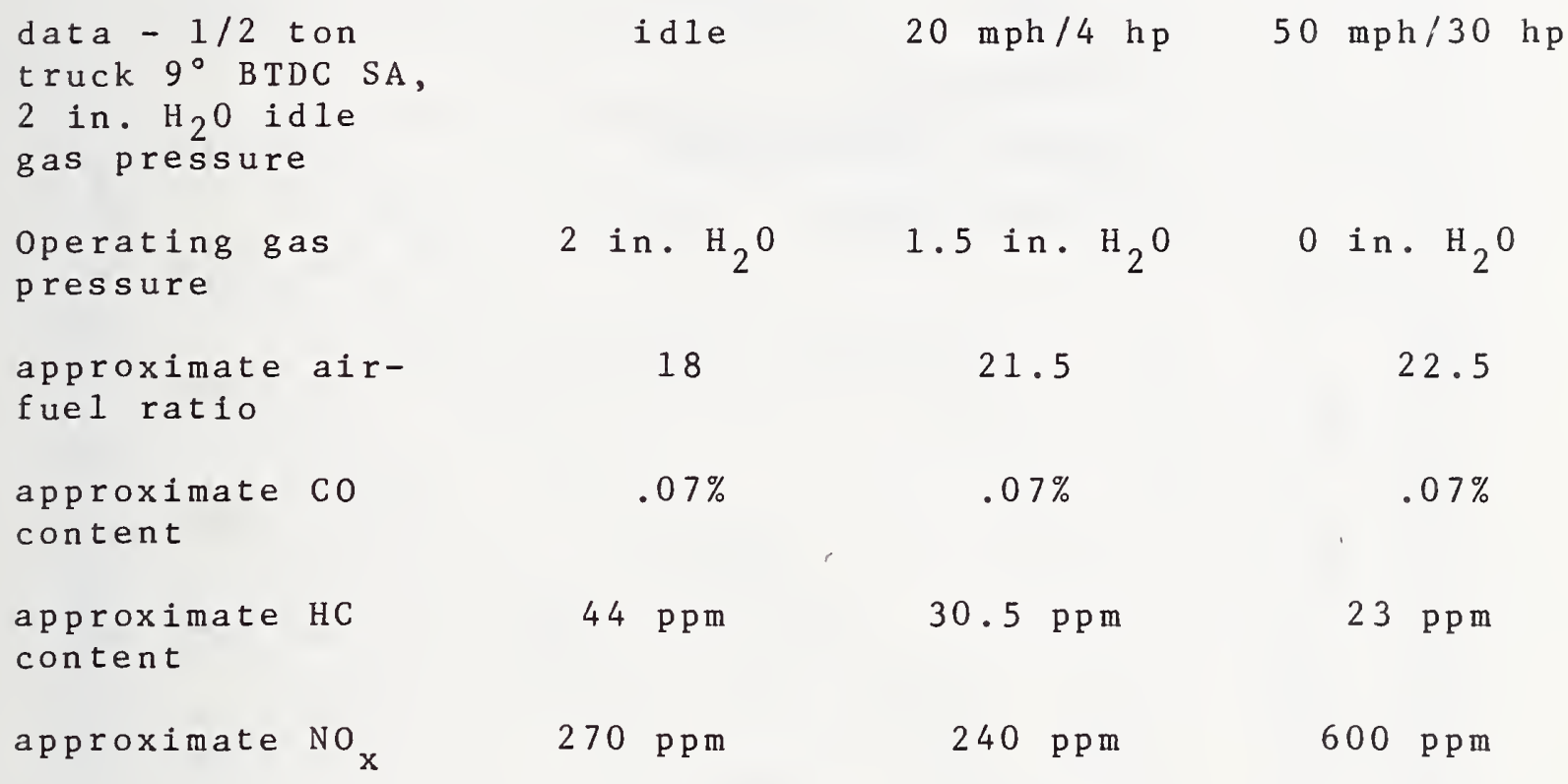

Figure 41 shows why the $A / F$ ratio decreased. For a given idle gas pressure, the resulting gas pressure at running conditions was decreased as the running speed and load were increased. This reduced pressure no doubt forced less fuel into the air mixer thus increasing the air-fuel ratio.

Figures 42 through 45 are for air-fuel ratio tests that were conducted at $110^{\circ} \mathrm{F}$ chamber temperature. The variation of $\mathrm{NO}_{\mathrm{x}}, \mathrm{HC}$, and $\mathrm{CO}$ is as noted previously, In addition,

\footnotetext{
* Trade names are used in this report as a means for clear identification to the Postal Service of their property. Use of a trade name neither constitutes nor implies endorsement by the National Bureau of Standards.
} 


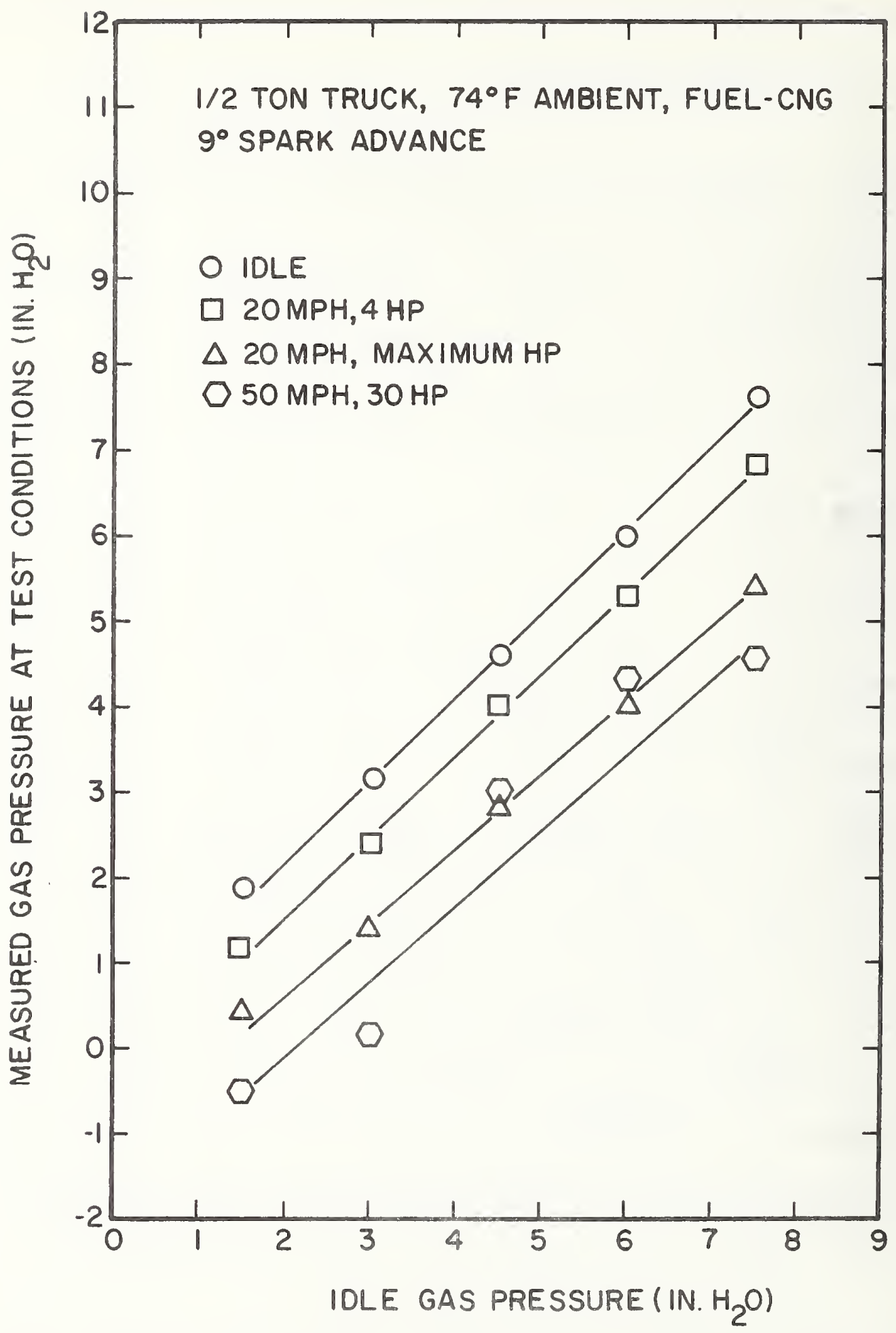

Figure 41 Gas Pressure at Running Conditions Versus Idle Gas Pressure for a $1 / 2$ Ton Truck Using CNG 


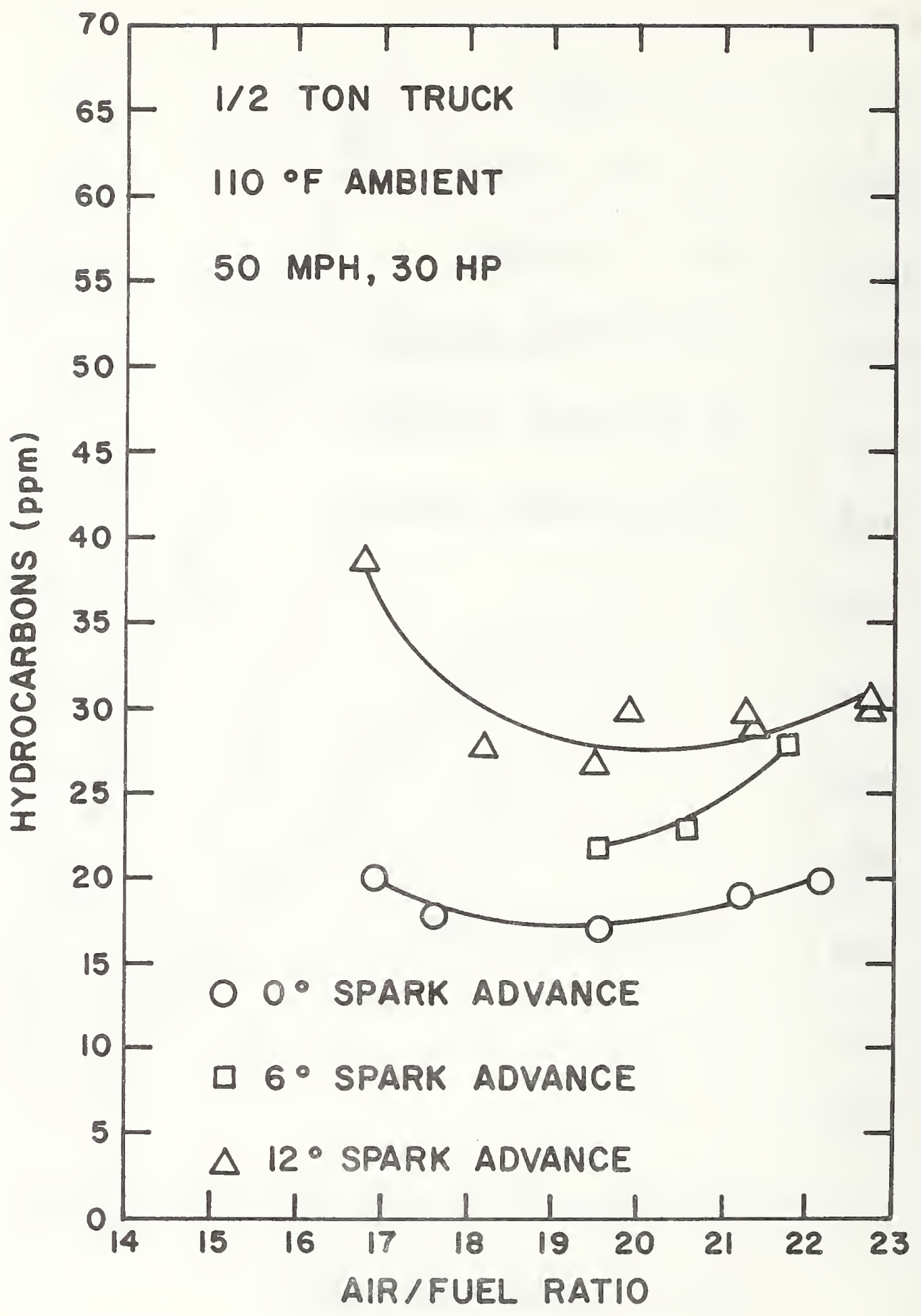

Figure 43 Hydrocarbons Versus Air-Fuel Ratio for a $1 / 2$ Ton Truck Using CNG 


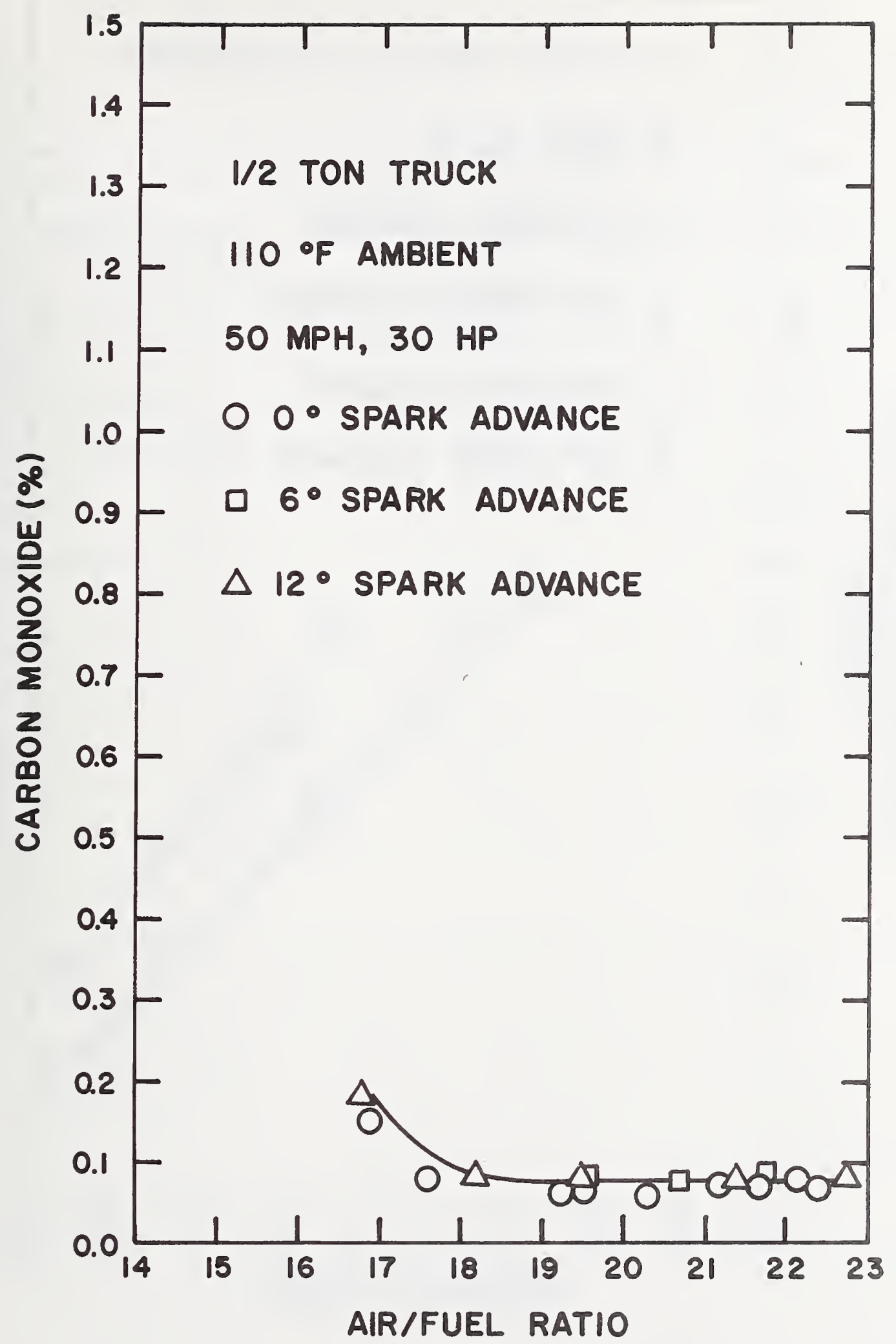

Figure 44 Carbon Monoxide Versus Air-Fuel Ratio for a $1 / 2$ Ton Truck Using CNG 


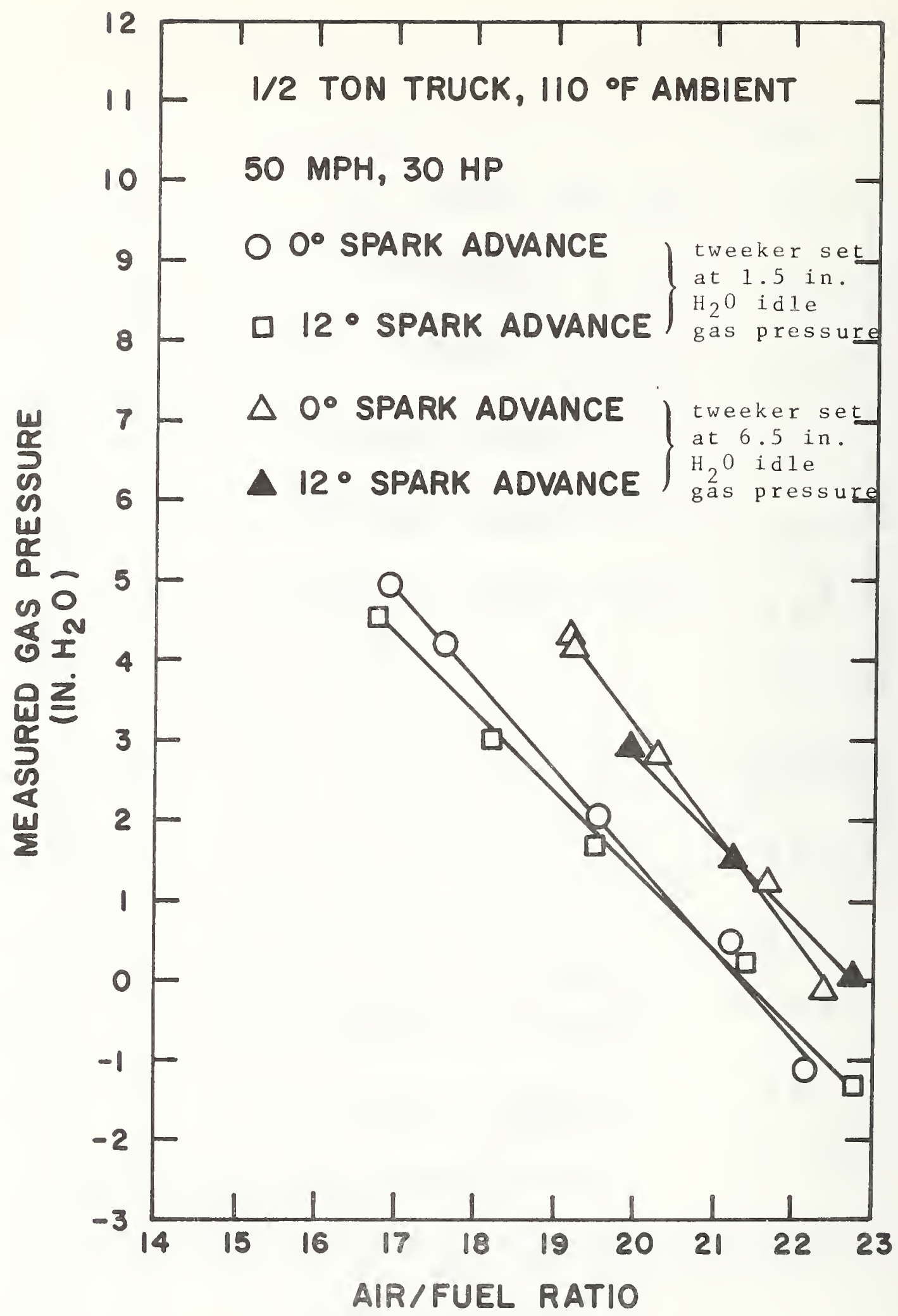

Figure 45 Gas Pressure at Running Conditions Versus Air-Fue 1 Ratio for a $1 / 2$ Ton Truck Using CNG 
Figure 45 illustrates the magnitude of effect that the tweeker had on the resulting air-fuel ratio. For convenience of testing, the tweeker was adjusted at one specific idle gas pressure (igp) and then the vehicle's simulated road speed was increased to $50 \mathrm{mph}$. When changing the gas pressure (in order to obtain a different A/F ratio), it was simply increased or decreased by approximately 1.5 in. $\mathrm{H}_{2} \mathrm{O}$ (with no readjustment of the tweeker) and data was taken. It was not important in these laboratory tests to readjust the tweeker after each change since different values of A/F ratio were all that were necessary. However, at $0^{\circ}$ and $12^{\circ}$ spark advance the test was conducted twice, the tweeker being adjusted, at the low end of the pressure range once and at the upper end before the second test. As can be seen, this difference in tweeker setting for a specified measured gas pressure caused a difference as 1 arge as 2 in the air-fue 1 ratio.

Figures 46 and 47 show a comparison between the data taken at $74^{\circ} \mathrm{F}$ and that at $110^{\circ} \mathrm{F}$ for the spark set at $6^{\circ}$ before top dead center at idling. It must be concluded as a result of this comparison, that a temperature change from $70^{\circ} \mathrm{F}$ to $110^{\circ} \mathrm{F}$ had little effect on the pollutants for the same spark advance and A/F ratio.

Figures 48 through 51 show the results of tests conducted at a low temperature $\left(17^{\circ} \mathrm{F}\right.$ at the radiator). Figure 48 shows very clearly the way in which $N_{x}$ peaked at an air-fuel ratio just to the lean side of stoichiometric conditions. Figure 


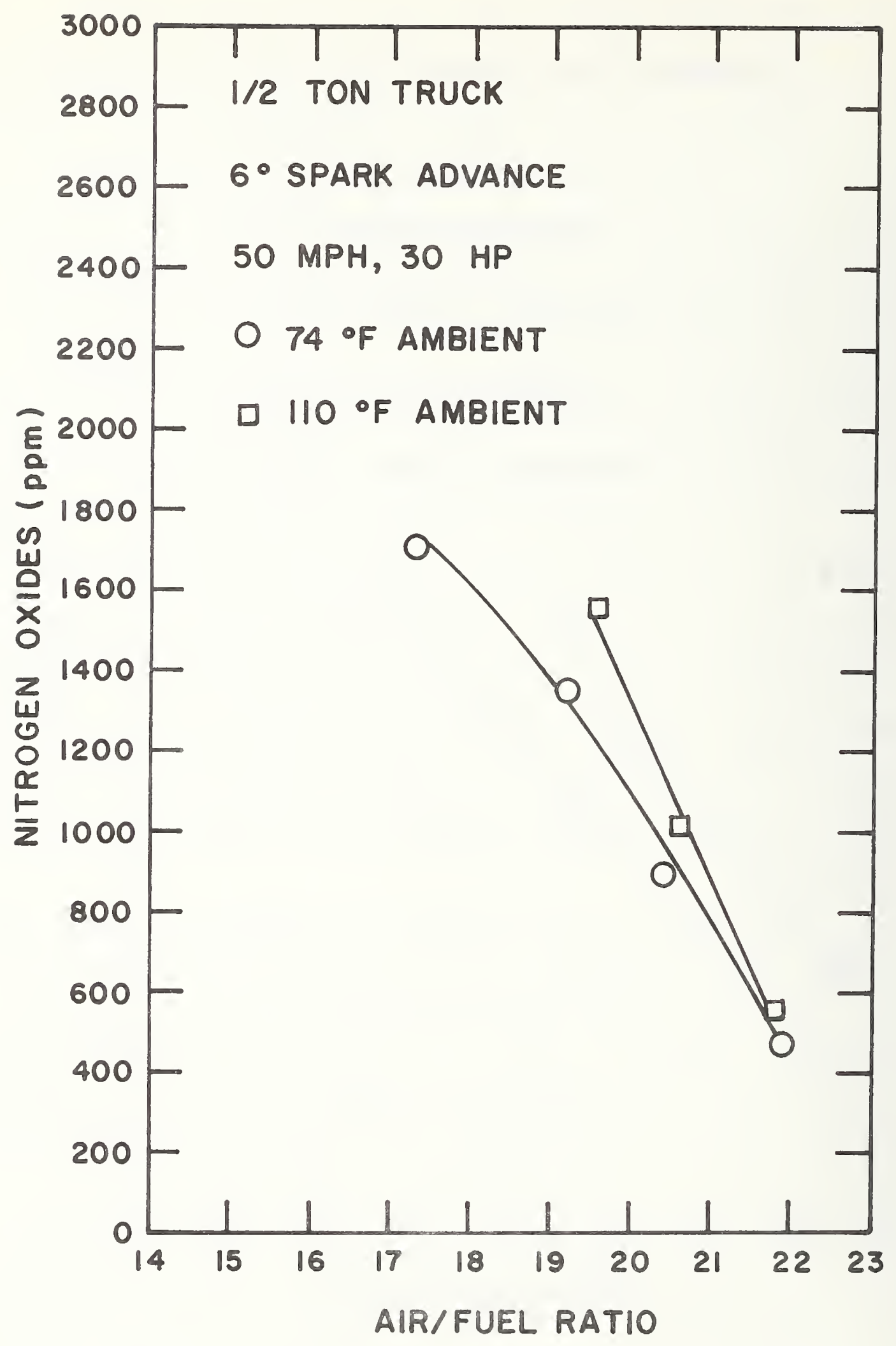

Figure 46 Nitrogen oxides Versus Air-Fuel Ratio for a $1 / 2$ Ton Truck Using CNG 


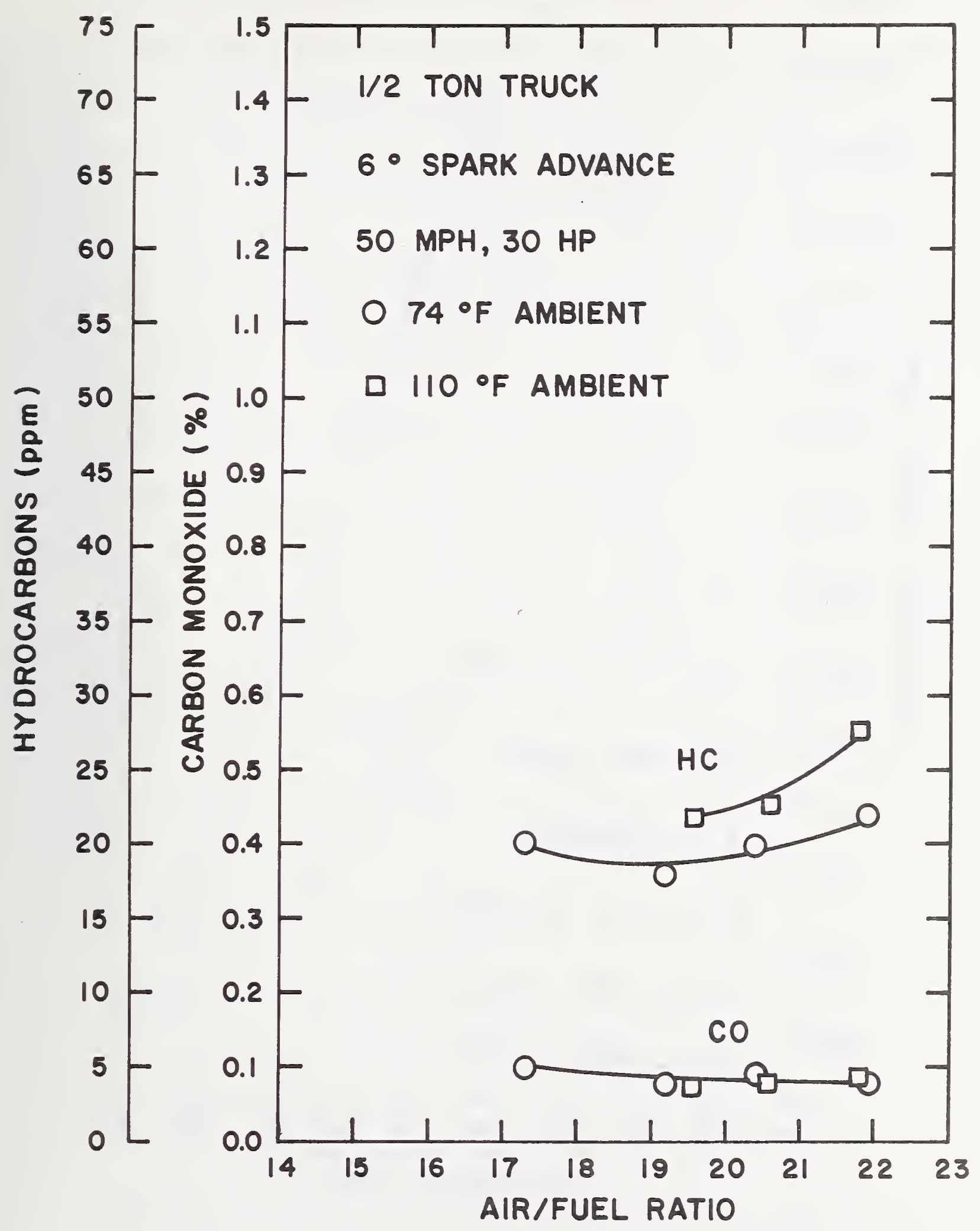

Figure 47 Hydrocarbons and Carbon Monoxide Versus Air-Fue 1 Ratio for a $1 / 2$ Ton Truck Using CNG 


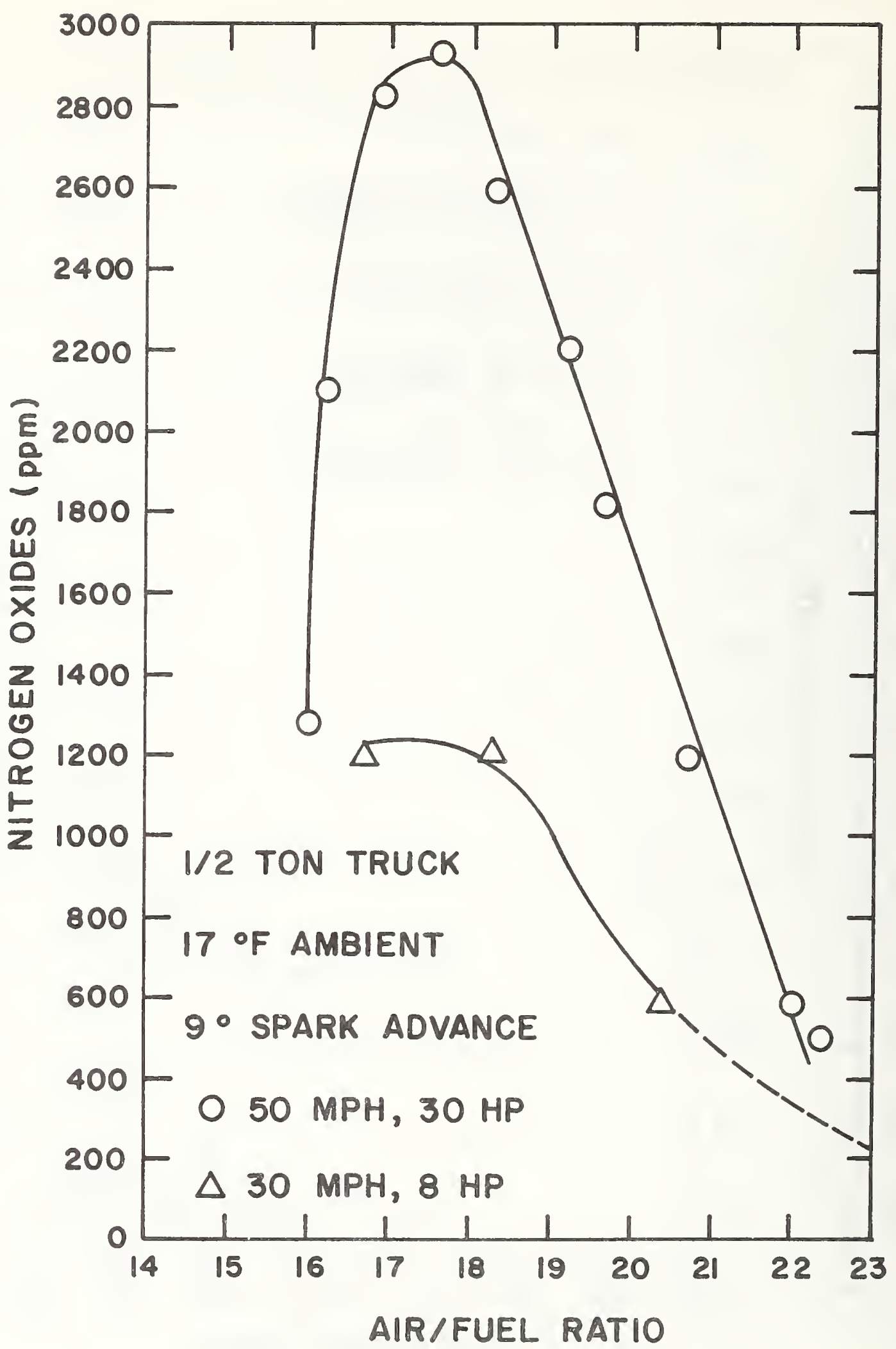

Figure 48 Nitrogen Oxides Versus Air-Fuel Ratio for a $1 / 2$ Ton Truck Using CNG 
49 also demonstrates what occurred with the co content of the exhaust gas when conditions were so rich that inefficient combustion resulted due to a lack of sufficient air. Figure 50 shows the horsepower that was obtained from the vehicle running at $20 \mathrm{mph}$ with the throttle wide open and a $9^{\circ}$ spark setting. The pollutant values shown are those that resulted from this "fully loaded" running condition. Figure 51 again serves to show the importance of the tweeker. Comparing the two curves for $50 \mathrm{mph}$ and $30 \mathrm{hp}$, one sees that for a given measured gas pressure at running conditions, the tweeker setting affected a change of 2 or more in the air-fuel ratio.

Figures 52 and 53 show comparisons between the data of the "air-fuel ratio tests" conducted at $74^{\circ} \mathrm{F}$ and those conducted at $1.7^{\circ} \mathrm{F}$. Again it is noted that the gas system, carburetion system, and vehicle operated in such a way that pollutants did not change with environmental temperature provided the air-fuel ratio and spark setting were the same.

4.3 Propane-Fueled Tests

Figures 54 through 77 summarize the results of tests done on the $1 / 2$ ton truck when it was run using propane as the fuel.

4.3.1 Spark advance as the Independent Variable

Figures 54,55 , and 56 show the way in which the pollutants varied with spark advance set at idling speed for three different runing conditions at the ambient temperature of 


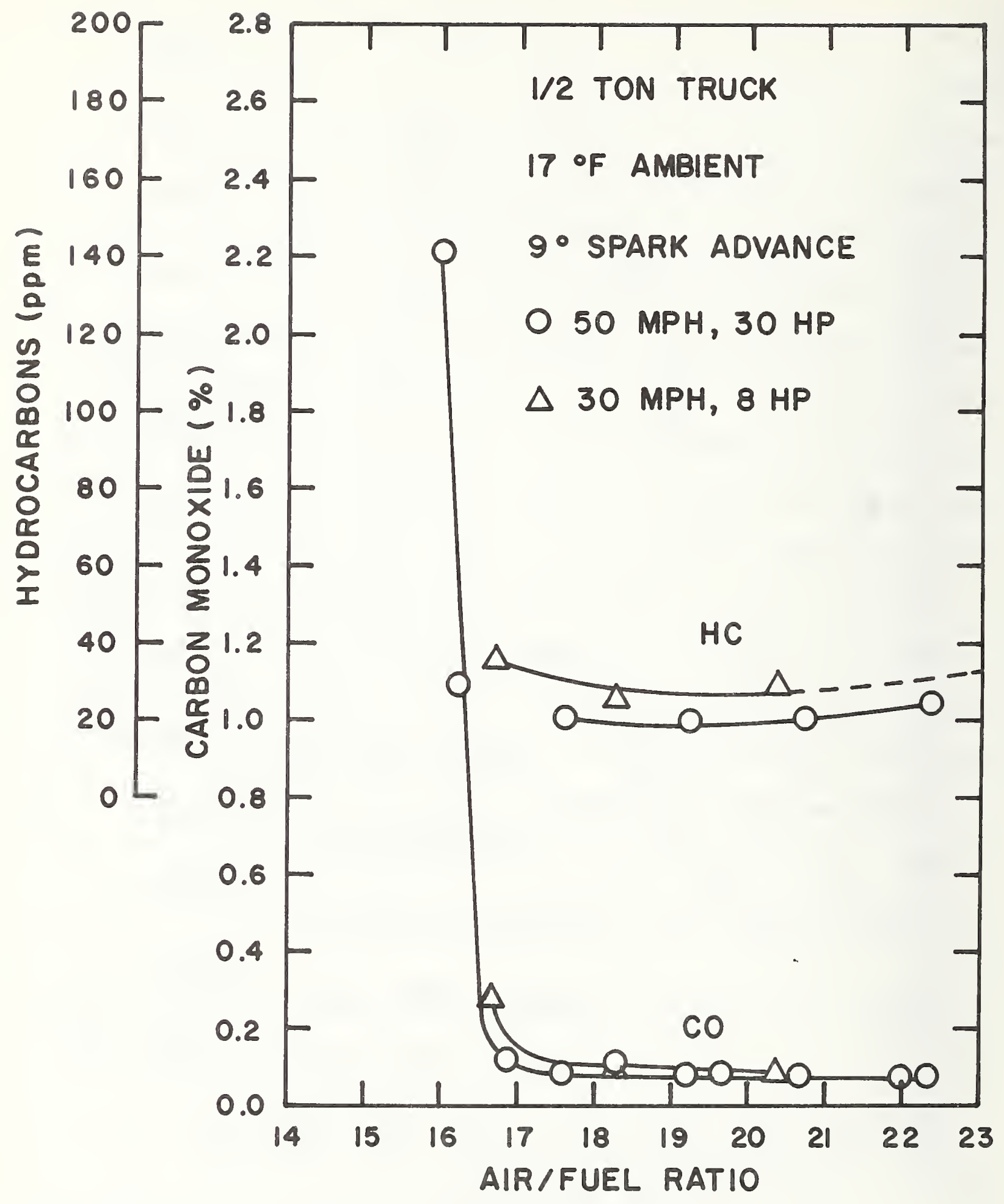

Figure 49 Hydrocarbons and Carbon Monoxide Versus Air-Fuel Ratio for a $1 / 2$ Ton Truck Using CNG 


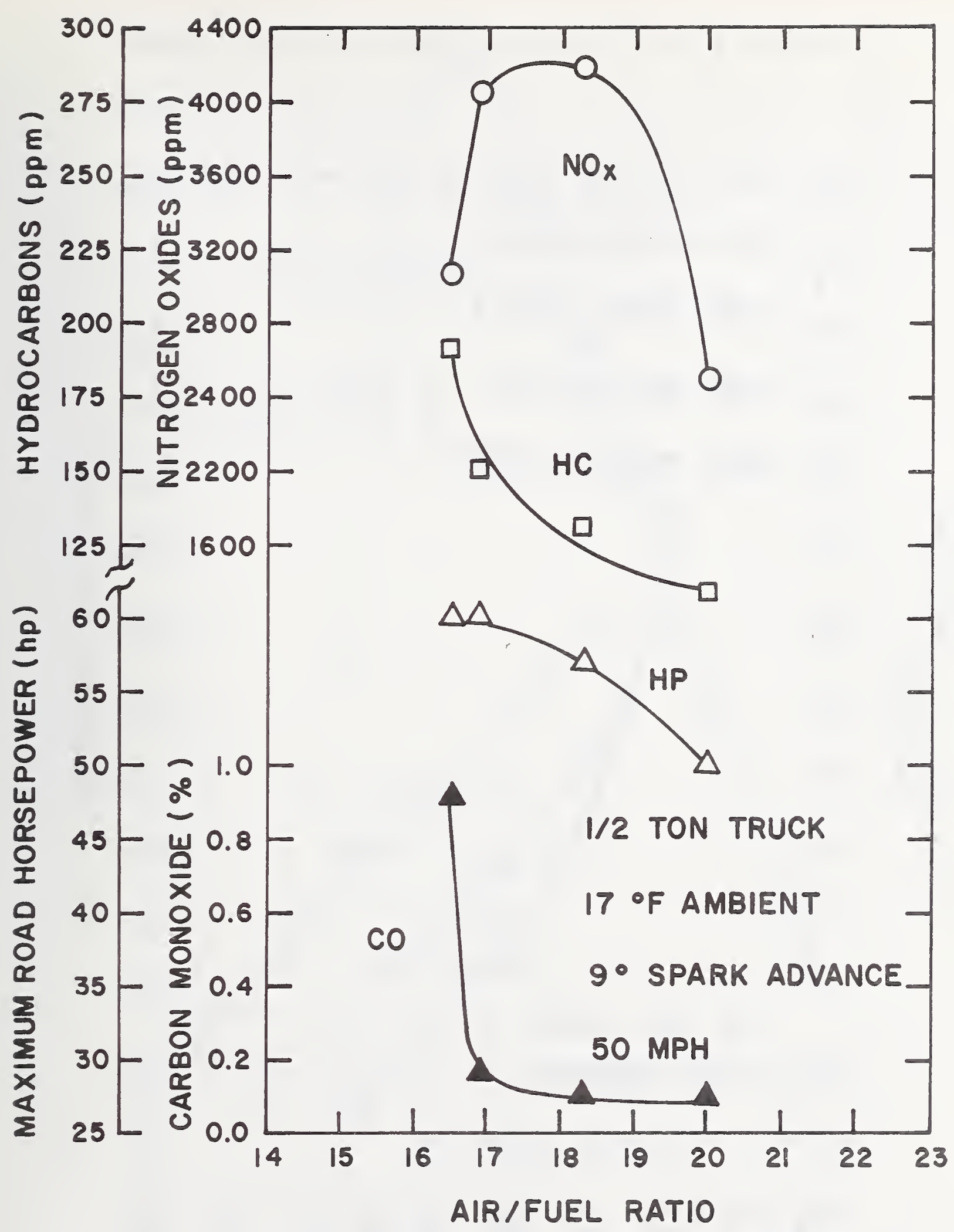

Figure 50 Maximum Horsepower and Pollutants Versus Air-Fue 1 Ratio for a $1 / 2$ Ton Truck Using CNG and operating at Full Throttle 


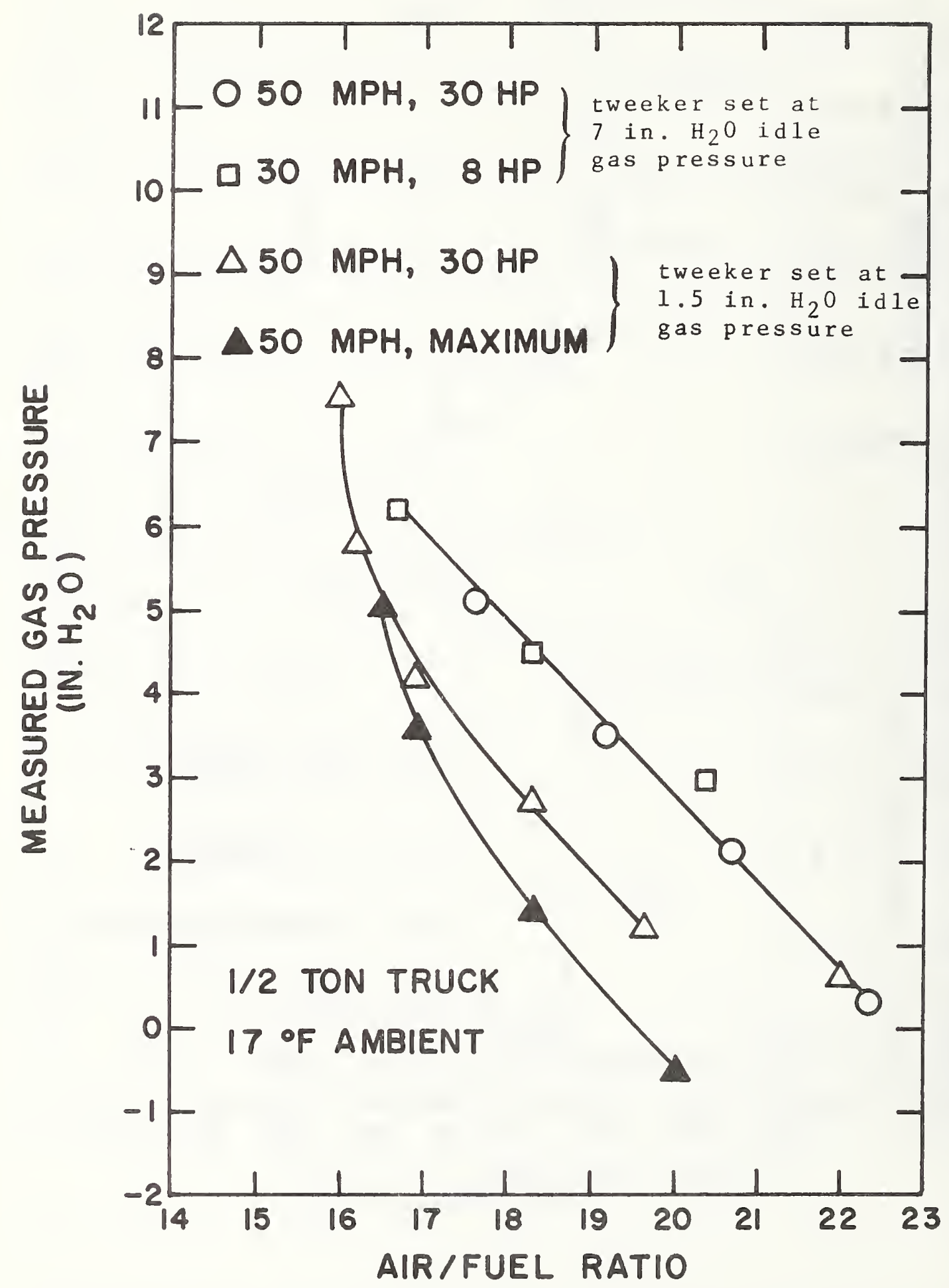

Figure 51 Gas Pressure at Running Conditions Versus Air-Fuel Ratio for a $1 / 2$ Ton Truck Using CNG 


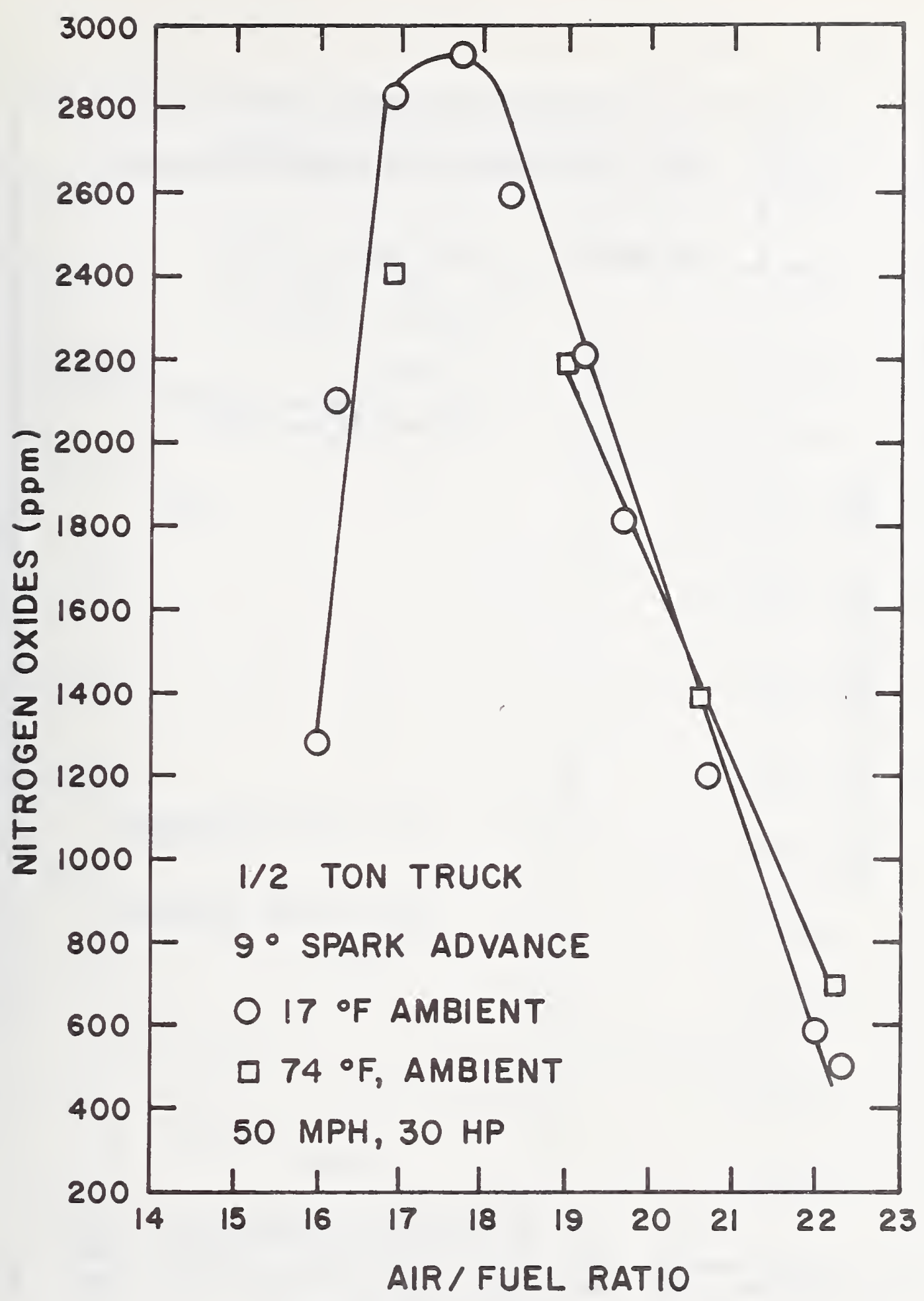

Figure 52 Nitrogen Oxides Versus Air-Fuel Ratio for a $1 / 2$ Ton Truck using CNG 


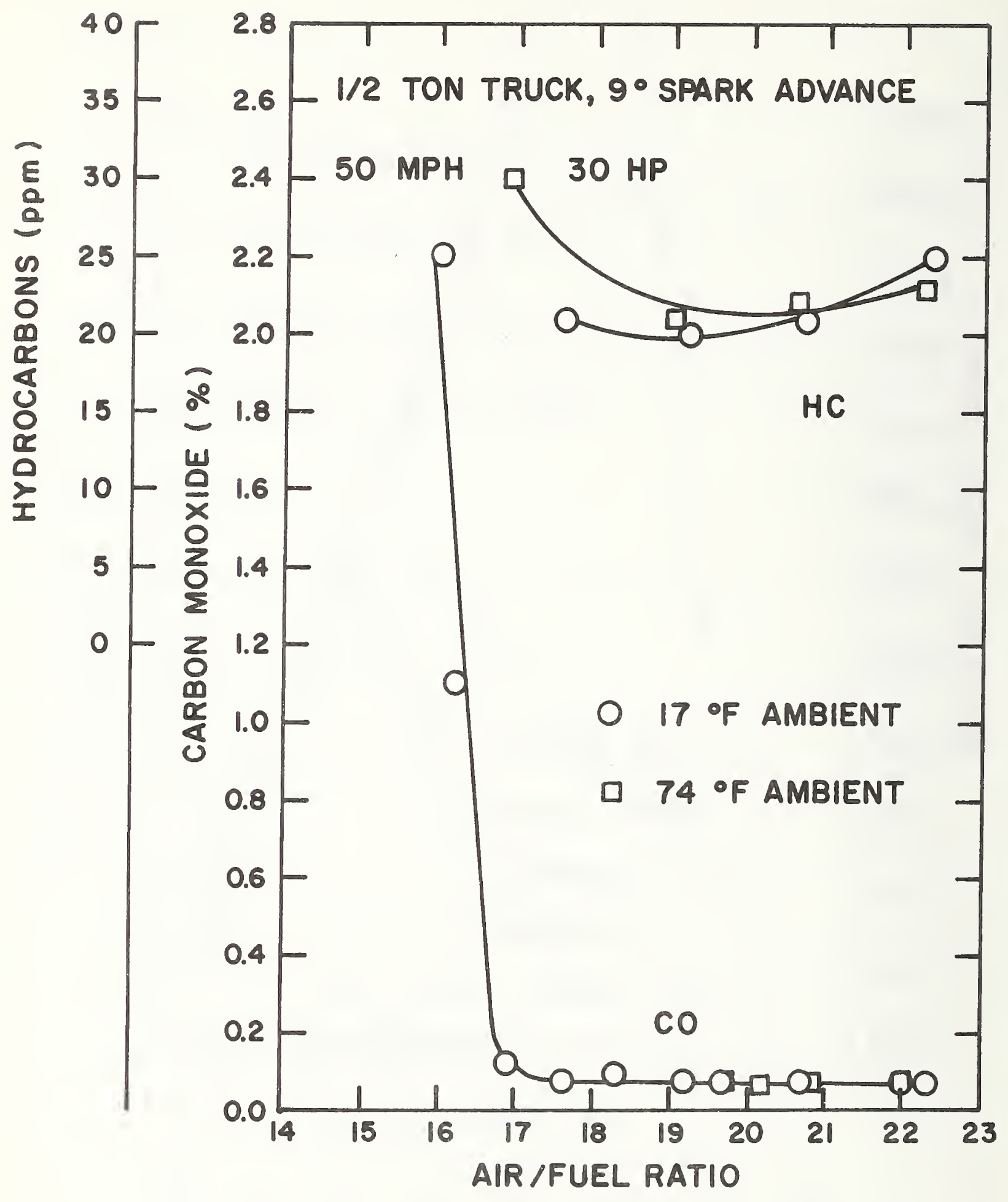

Figure 53 Hydrocarbons and Carbon Monoxide Versus Air-Fue 1 Ratio for a $1 / 2$ Ton Truck Using CNG 


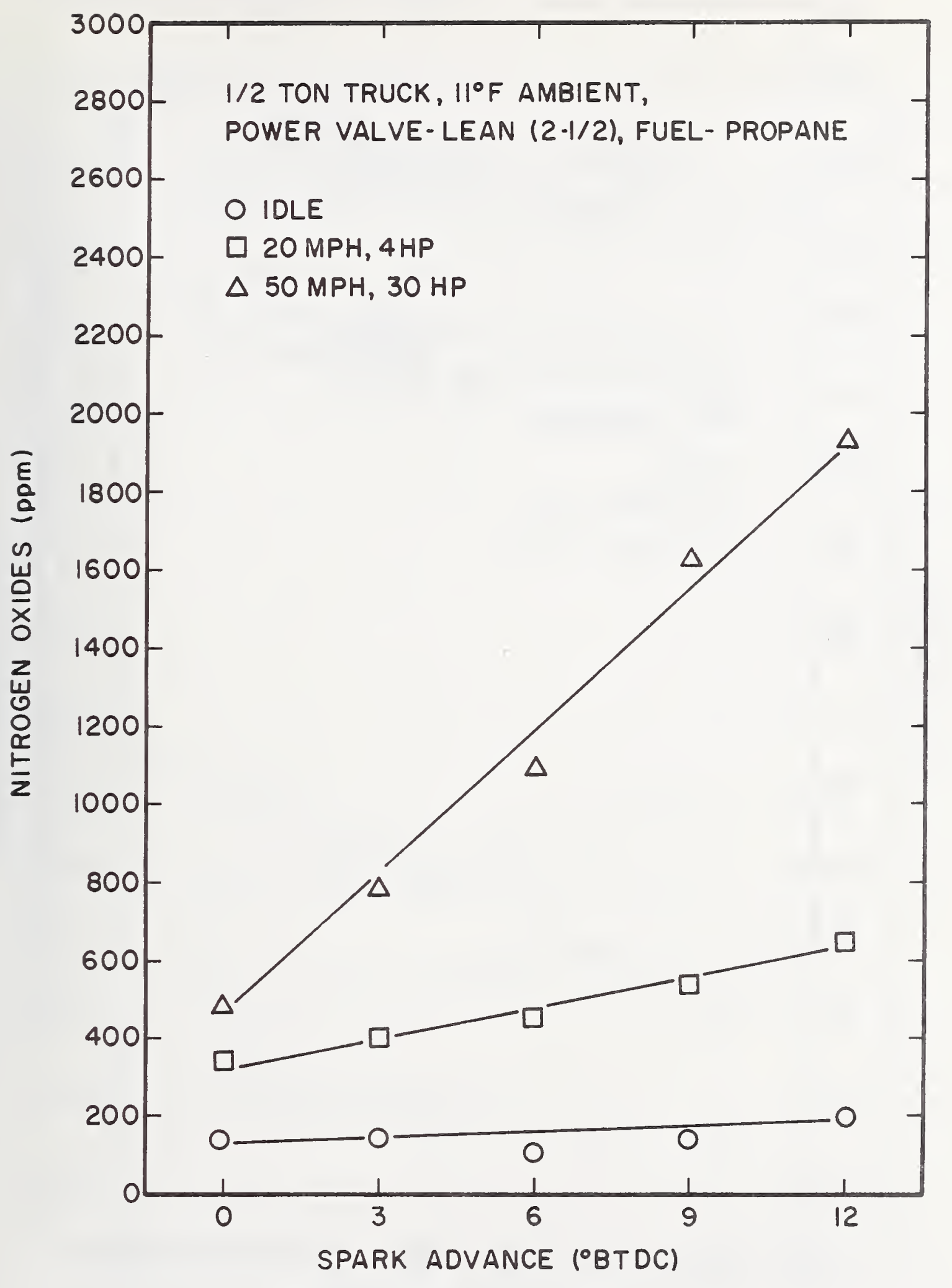

Figure 54 Nitrogen Oxides Versus Spark Advance for a $1 / 2$ Ton Truck Using LPG 


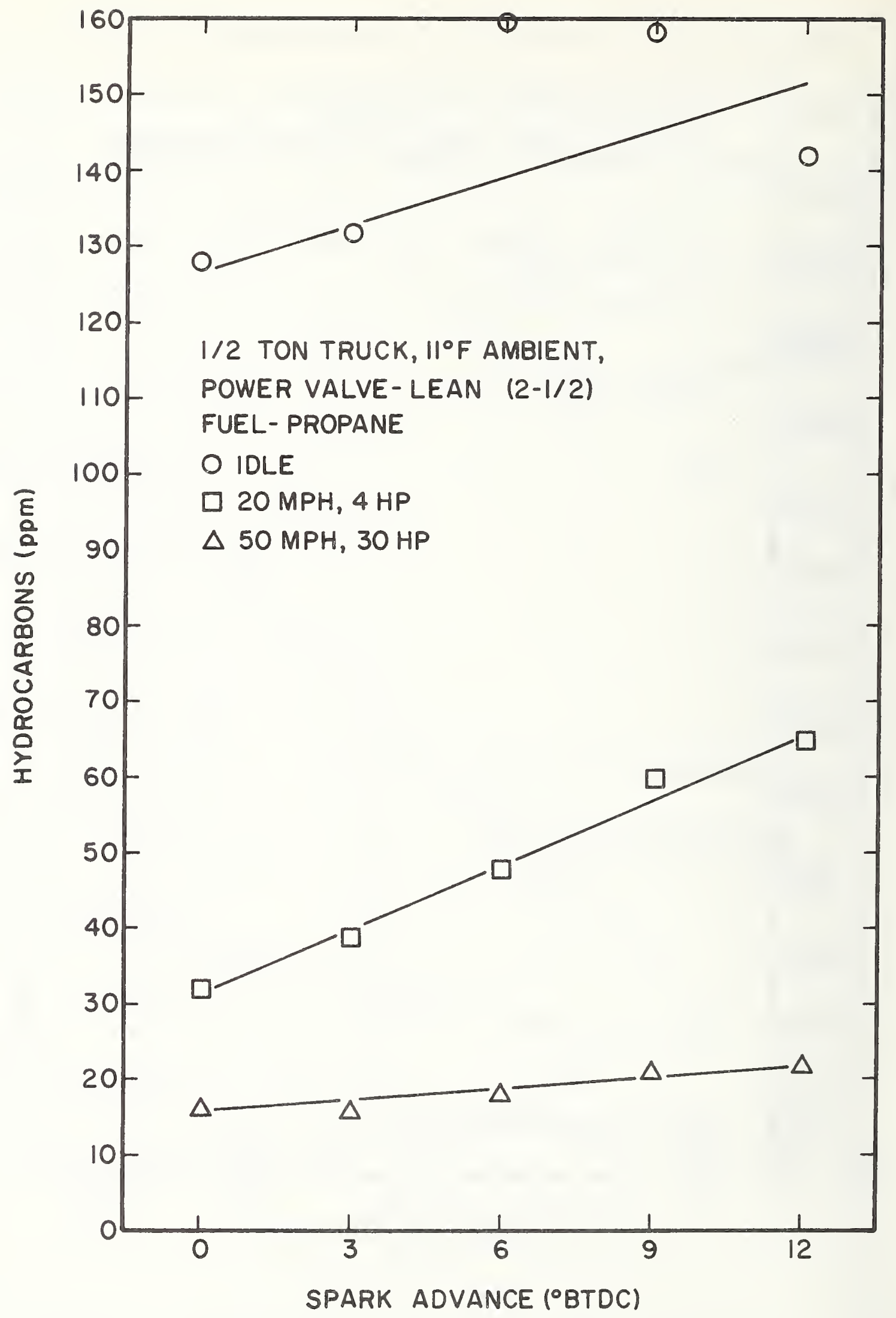

Figure 55 Hydrocarbons Versus Spark Advance for a $1 / 2$ Ton Truck Using LPG 


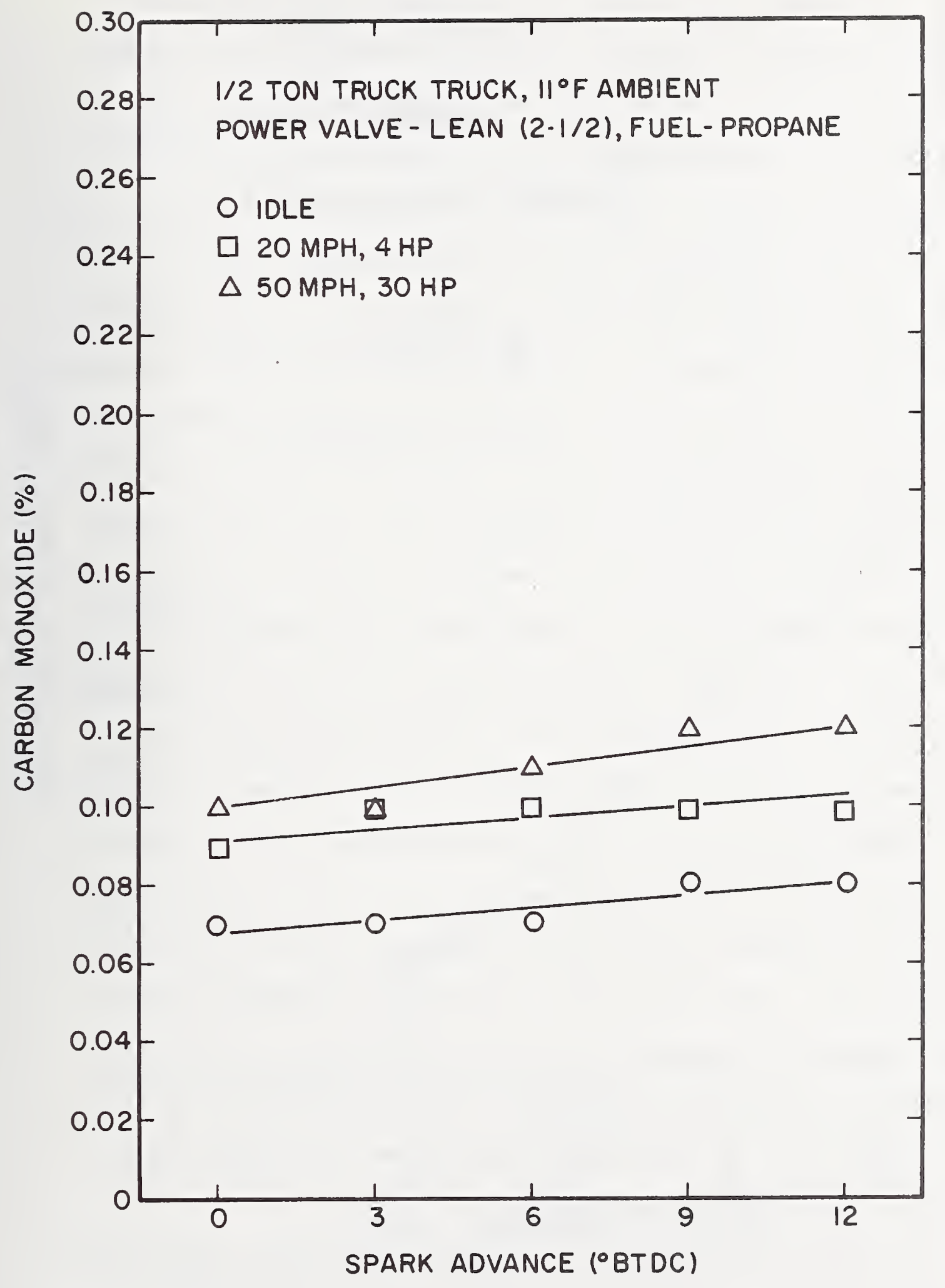

Figure 56 Carbon Monoxide Versus Spark Advance for a $1 / 2$ Ton Truck Using LPG 
$11^{\circ} \mathrm{F}$. Consistent with previous findings, the pollutants increased with spark advance, the $\mathrm{NO}_{\mathrm{x}}$ increased with load and speed, and the HC content was the largest while the vehicle was running at iding speed. It was expected that the co content would also be highest at the idling condition but this did not occur. However, the co content was so low for all three running conditions that the reversal in trend is not significant. The power valve setting at $21 / 2$ gave the leanest condition that could be used and still obtain 30 horsepower at 50 miles per hour for this low temperature and all idling spark settings from 0 to 12 degrees before top dead center (BTDC). At a 11 other ambient temperatures it was possible to obtain the desired load and speed with a setting of 2 on the restrictor. It would have been possible to use a position of 2 for the low temperature if 28 or 29 horsepower had been acceptable for the $0^{\circ} \mathrm{BTDC}$ setting. At no ambient temperatures was it possible to use a position setting of 1 .

Figures 57, 58, and 59 and Figures 60,61 , and 62 show results for similar tests at $76^{\circ} \mathrm{F}$ ambient and $114^{\circ} \mathrm{F}$ ambient respectively. All trends are consistent with the previous results with the exception that the co content was not the largest at the idling conditions. As mentioned above, the trend should not be considered significant in light of the relative low values in all cases.

The data in Figures 63 and 64 were plotted to give insight Into the way in which this dual-fuel regulating system operated. 


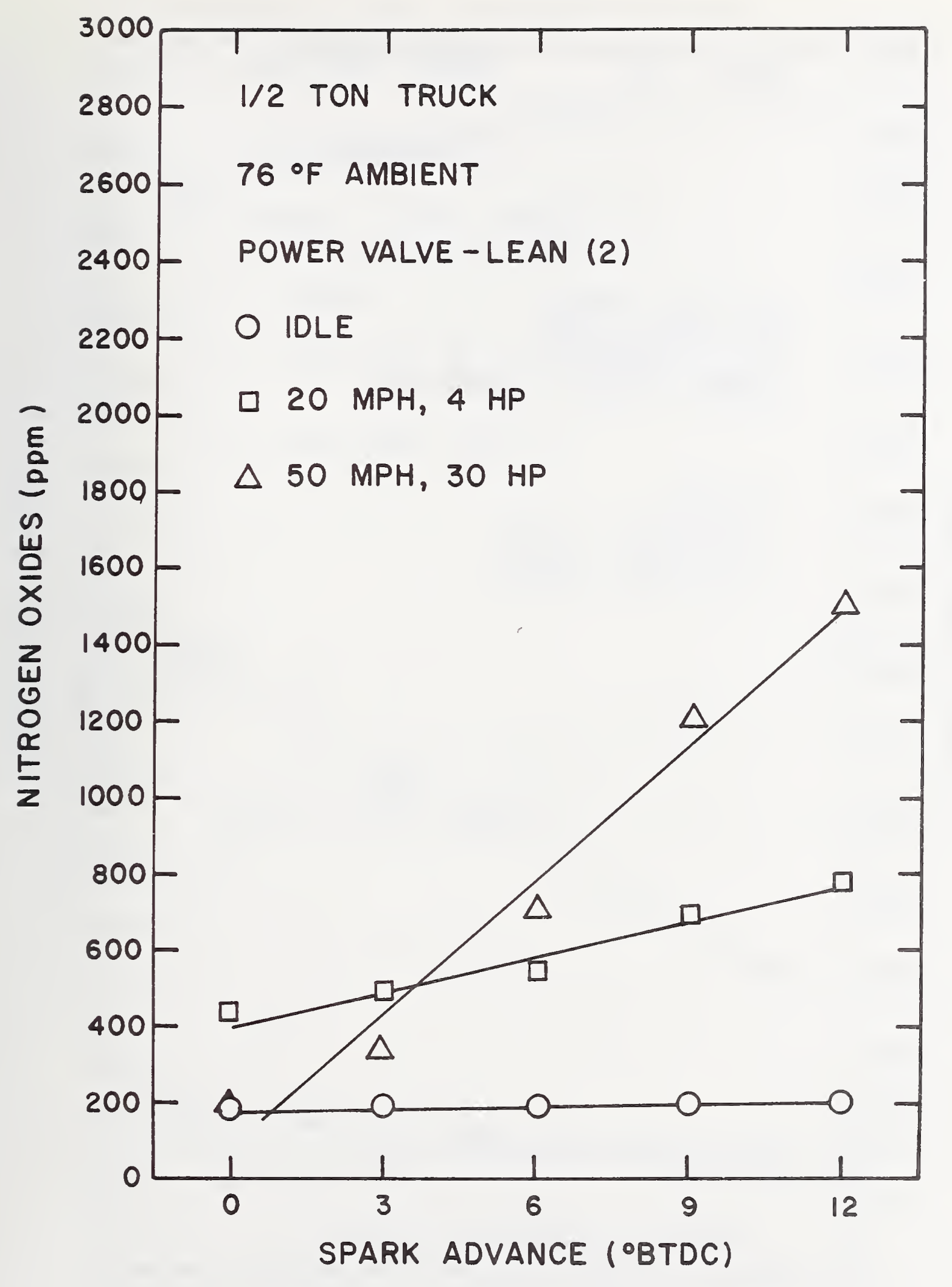

Figure 57 Nitrogen Oxides Versus Spark Advance for a $1 / 2$ Ton Truck Using LPG 


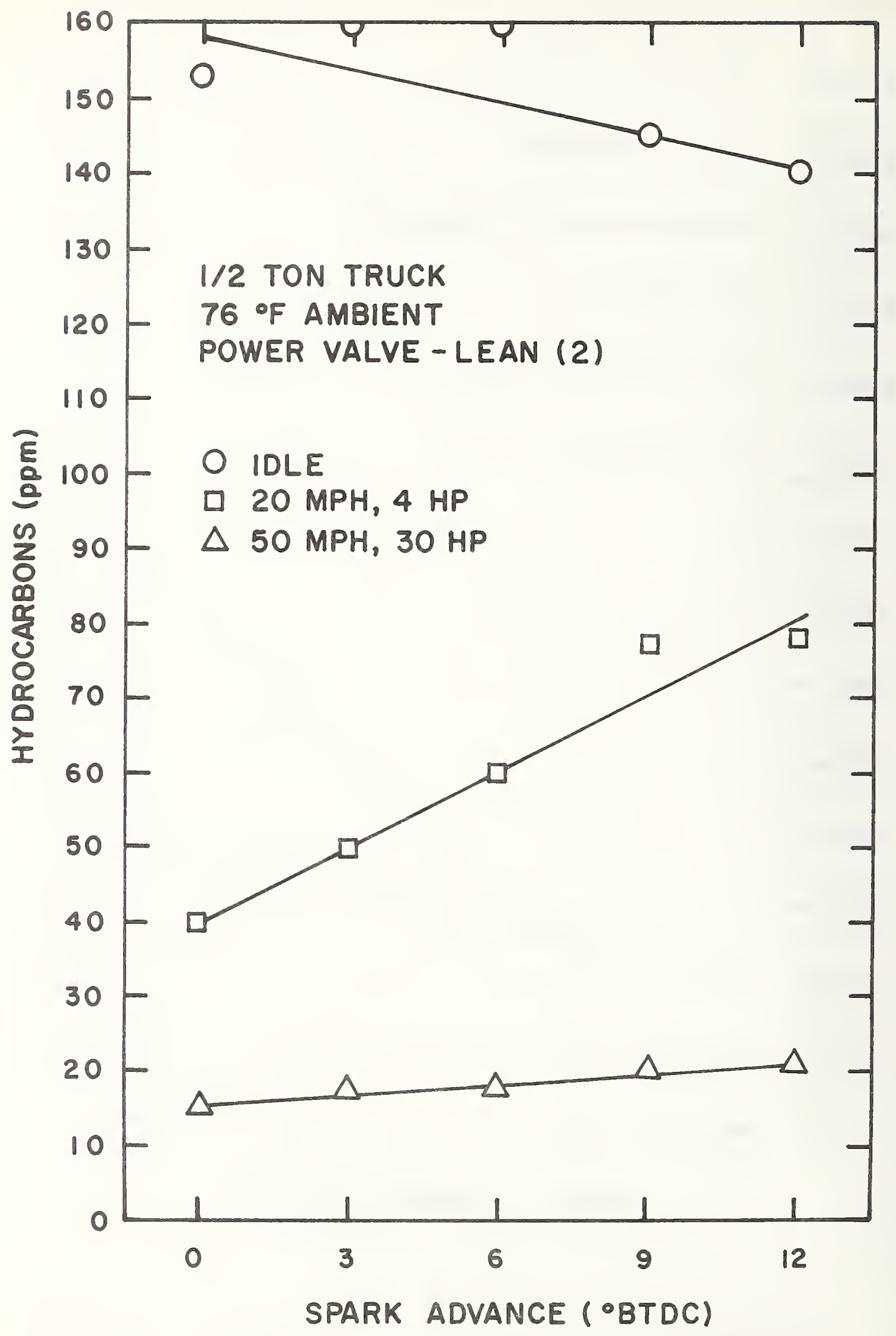

Figure 58 Hydrocarbons Versus Spark Advance for a $1 / 2$ Ton Truck Using LPG 


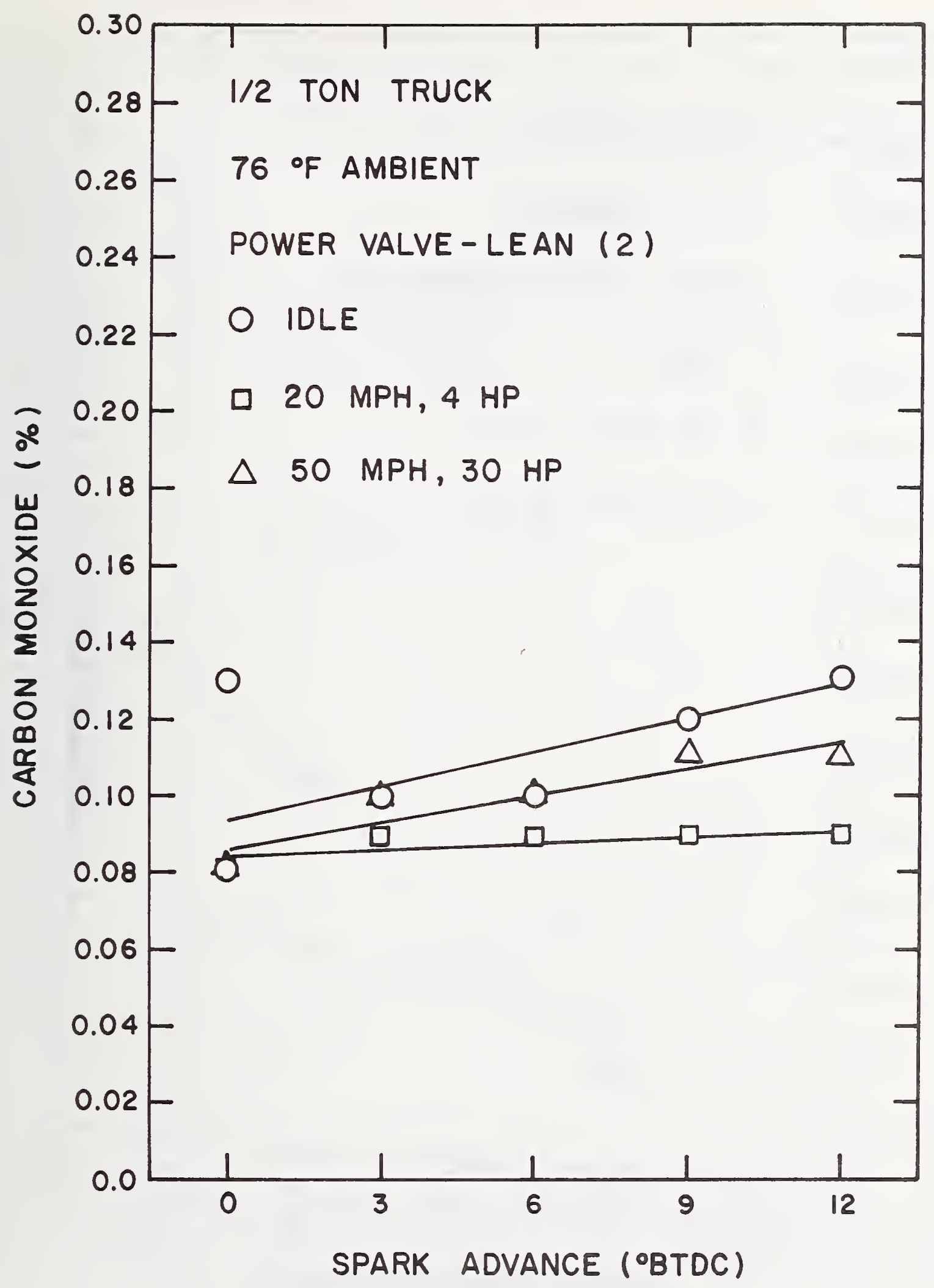

Figure 59 Carbon Monoxide Versus Spark Advance for a $1 / 2$ Ton Truck Using LPG 


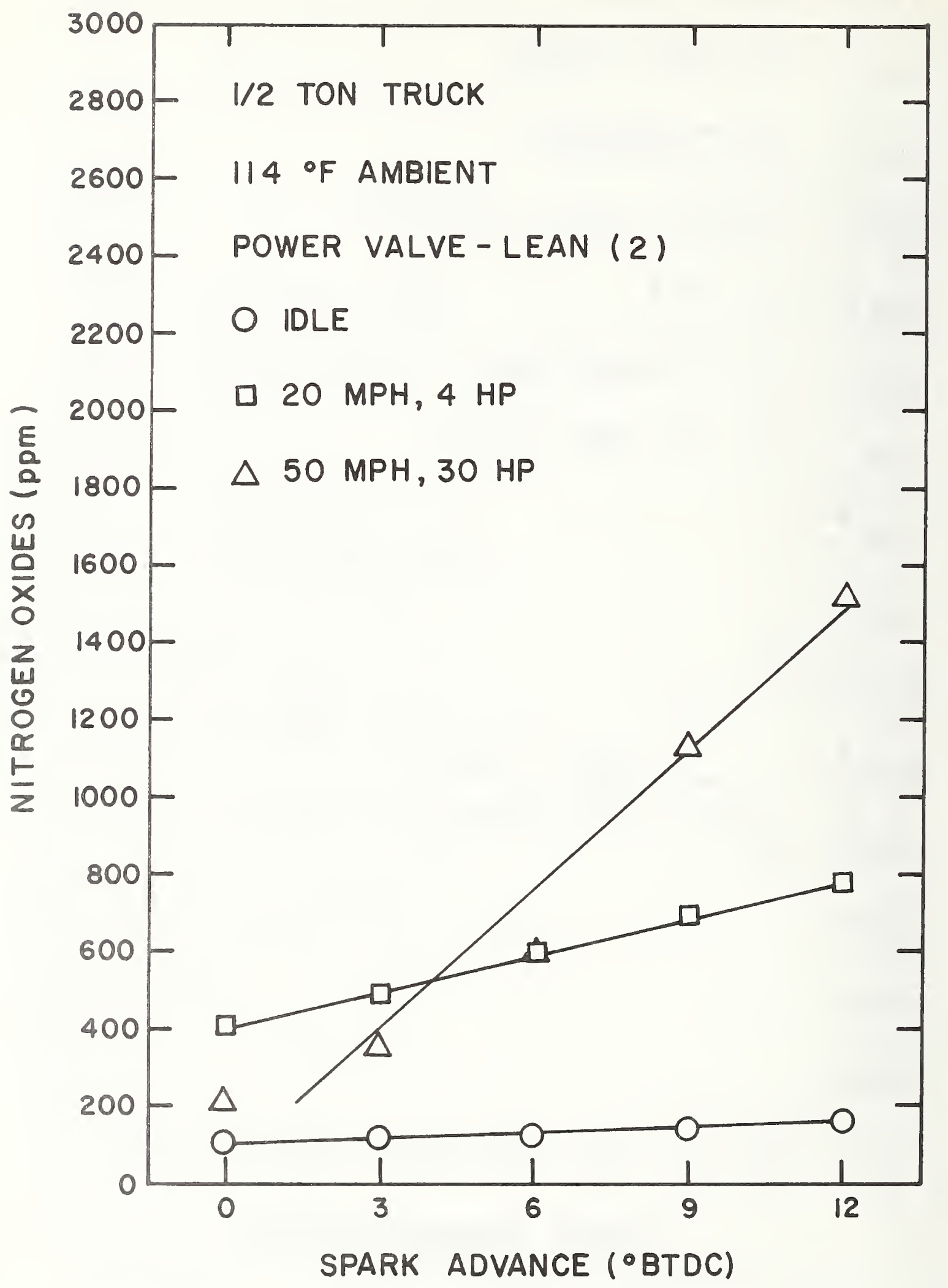

Figure 60 Nitrogen Oxides Versus Spark Advance for a $1 / 2$ Ton Truck Using LPG 


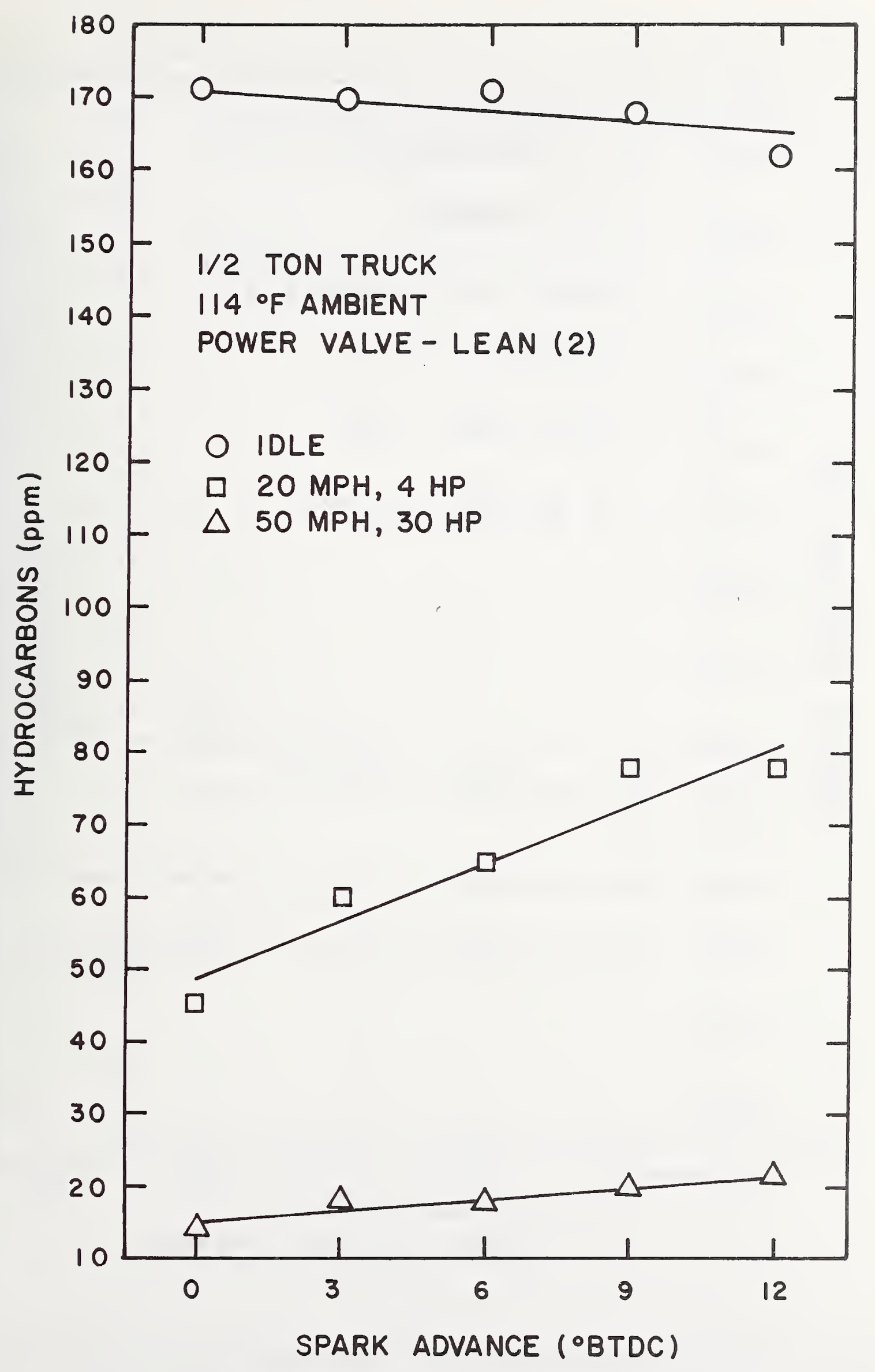

Figure 61 Hydrocarbons Versus Spark Advance for a $1 / 2$ Ton Truck Using LPG 


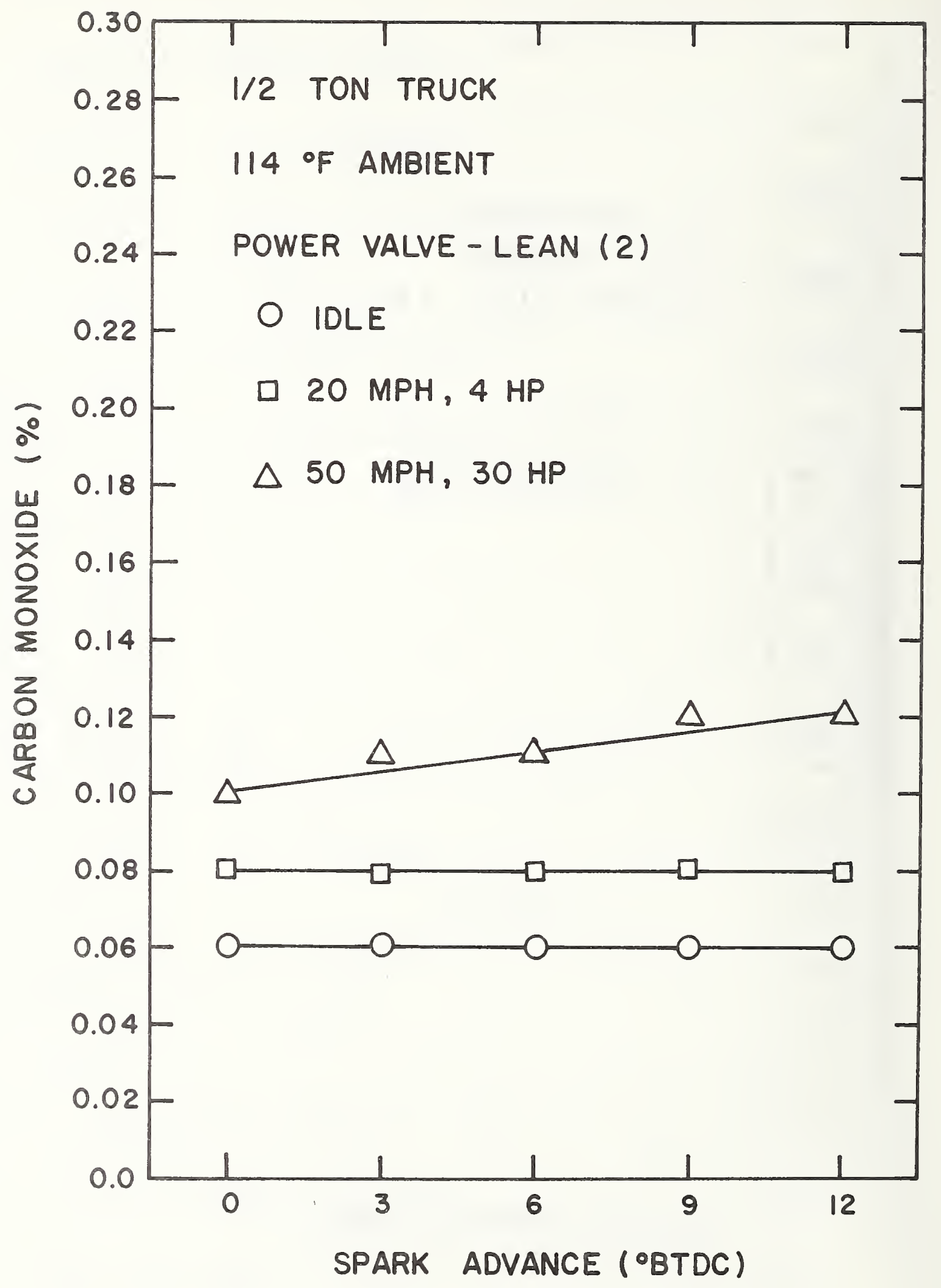

Figure 62 Carbon Monoxide Versus Spark Advance for a $1 / 2$ Ton Truck Using LPG 


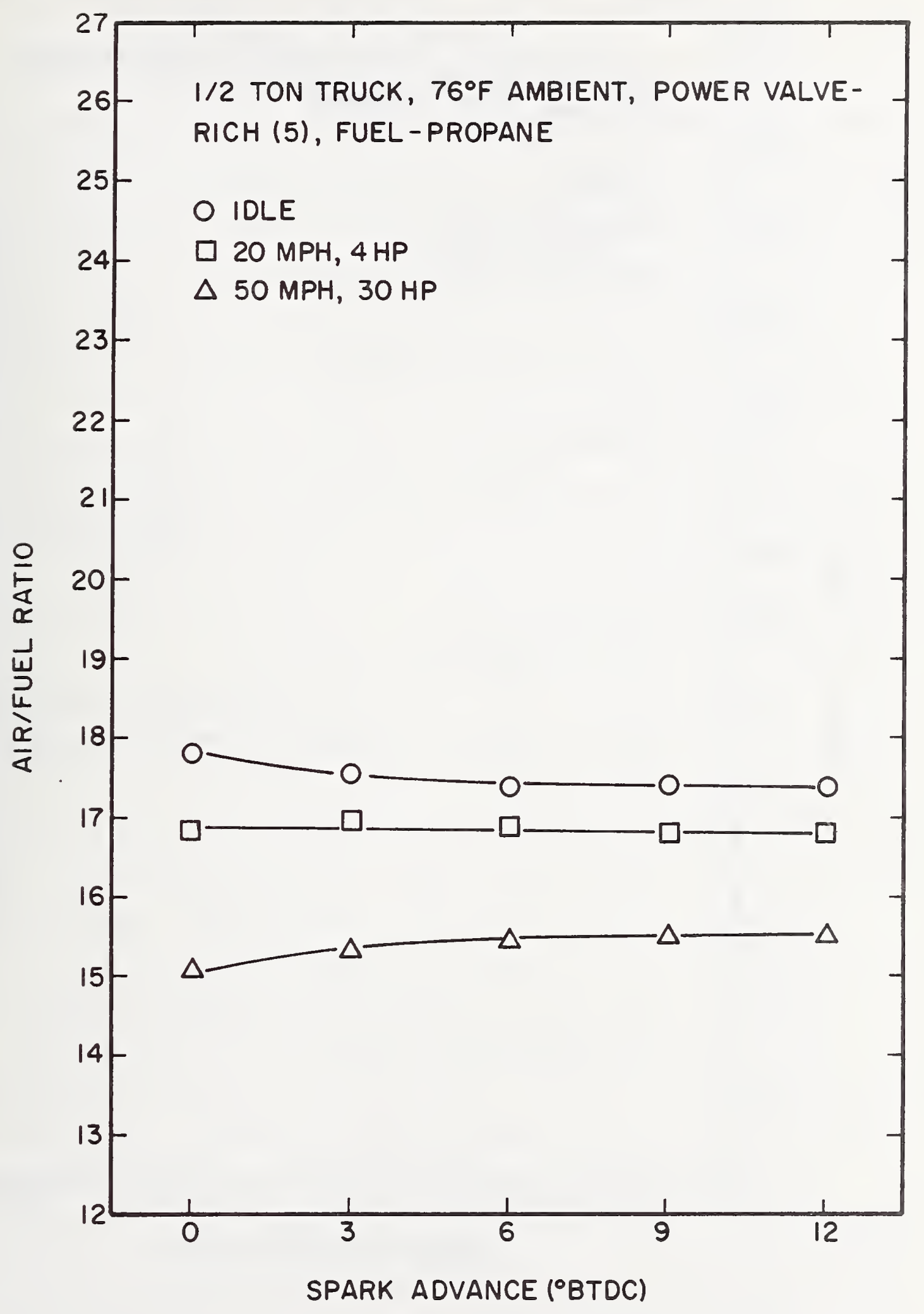

Figure 63 Air-Fuel Ratio Versus Spark Advance for a $1 / 2$ Ton Truck Using LPG 


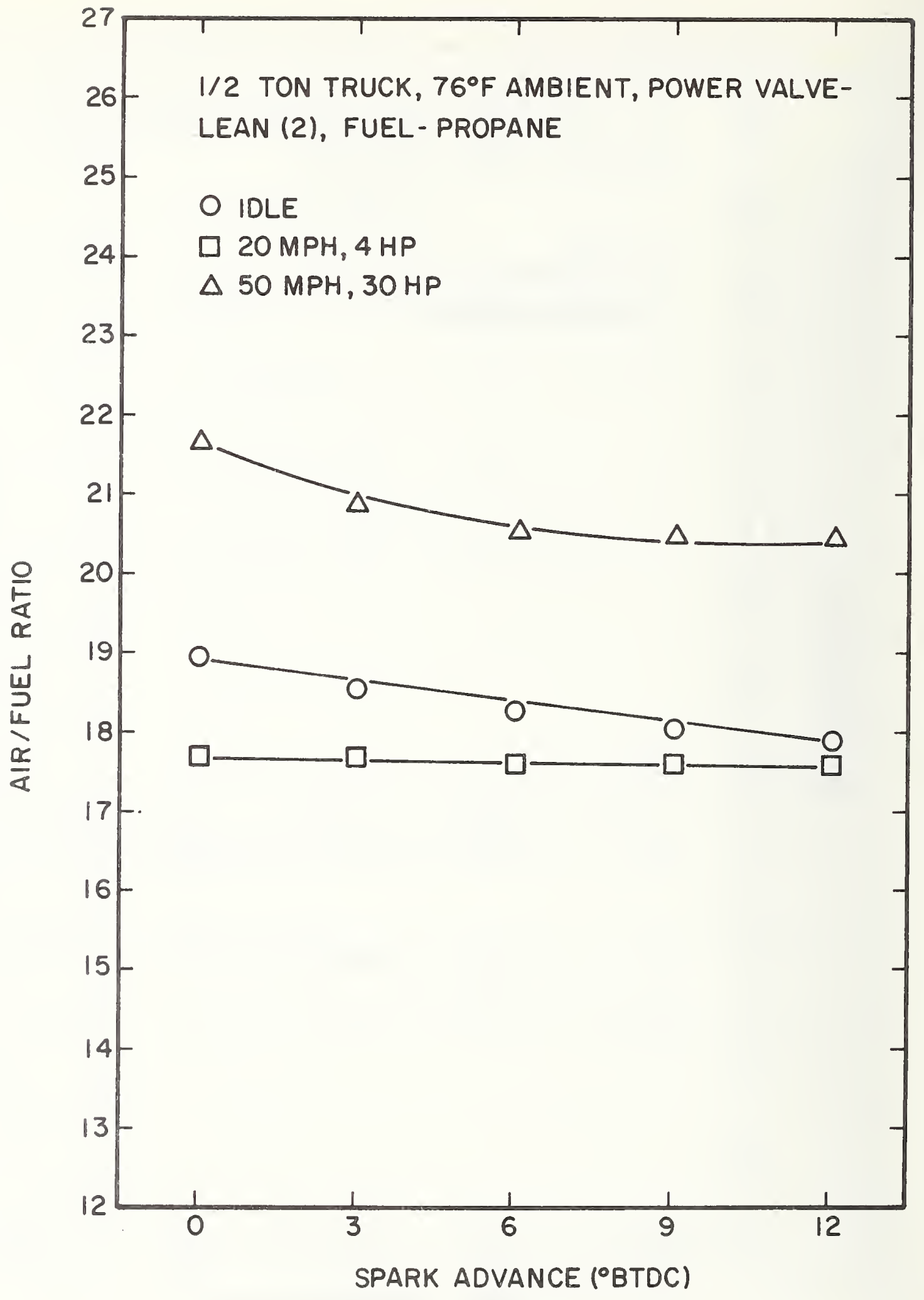

Figure 64 Air-Fue1 Ratio Versus Spark Advance for a $1 / 2$ Ton Truck Using LPG 
With the power valve or restrictor set at the lean position and for a given spark setting, the air-fuel ratio increased or the mixture got leaner as the load and speed increased (see Figure 63). This is precisely the way that the PALCo* dual-fuel system worked and seems to be best for minimizing the $\mathrm{NO}_{\mathrm{x}}$ content of the exhaust gases. As the load and speed are increased, the $\mathrm{NO}_{\mathrm{x}}$ would increase as we have already noted. However, this increase would be offset somewhat by the fuel regulating system operation whereby the mixture would simultaneously become leaner. Figure 64 shows that the fuel regulating system caused just the opposite to occur when the restrictor was positioned for a rich running condition.

4.3.2 Air-Fuel Ratio as the Independent Variable

Figures 65,66 , and 67 are for tests where the air-fue 1 ratio was varied (by varying the restrictor position) while runing the vehicle at $11^{\circ} \mathrm{F}$ ambient temperature and a variety of idling spark settings and running speeds and loads. As was the case previously, the ivo $x$ content decreased rapidly as the air-fuel ratio was made more lean past stoichiometric conditions. (The stoichiometric air-fuel ratio is approximately 15.7 for LPG.) In addition, the HC and Co content decreased and leveled off at an air-fuel ratio of approximately 18 . Figures 68, 69, and 70, and Figures 71,72 , and 73 show similar results for ambient temperatures of $72^{\circ} \mathrm{F}$ and $114^{\circ} \mathrm{F}$ respectively.

\footnotetext{
* Trade names are used in this report as a means for clear identification to the Postal Service of their property. Use of a trade name neither constitutes nor implies endorsement by the National Bureau of Standards.
} 


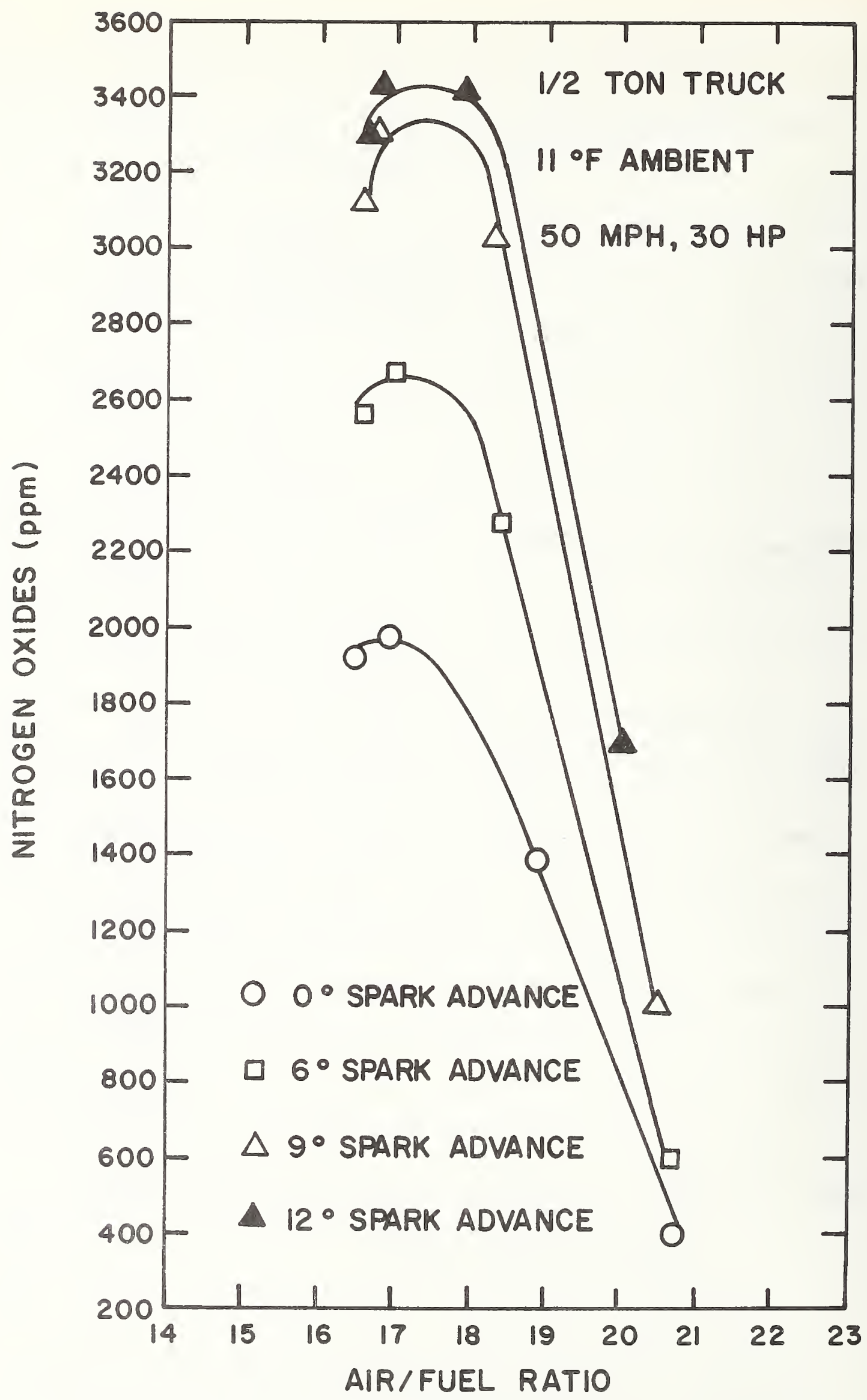

Figure 65 Nitrogen Oxides Versus Air-Fuel Ratio for a $1 / 2$ Ton Truck Using LPG 


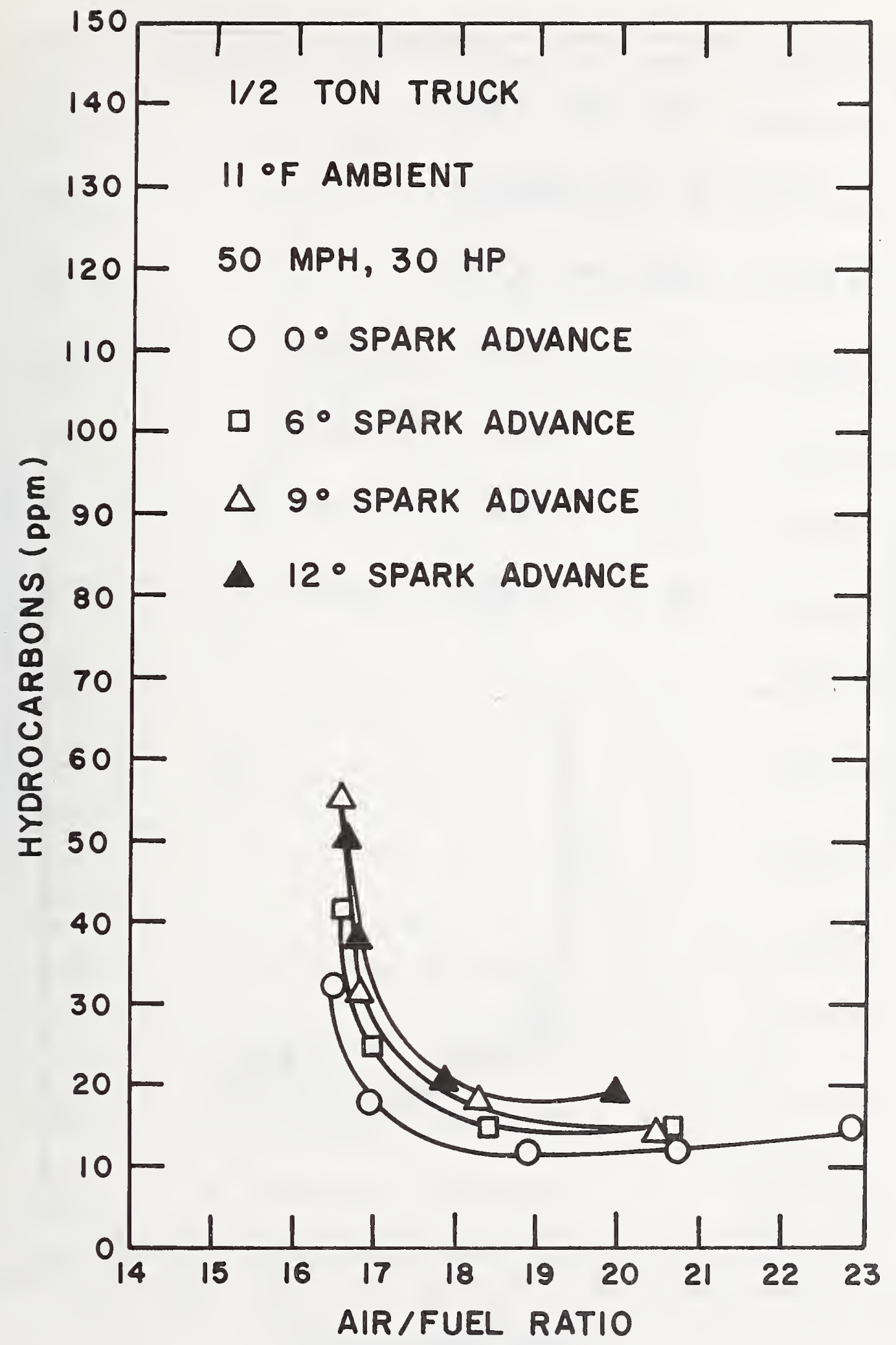

Figure 66 Hydrocarbons Versus Air-Fuel Ratio for a $1 / 2$ Ton Truck Using LPG 


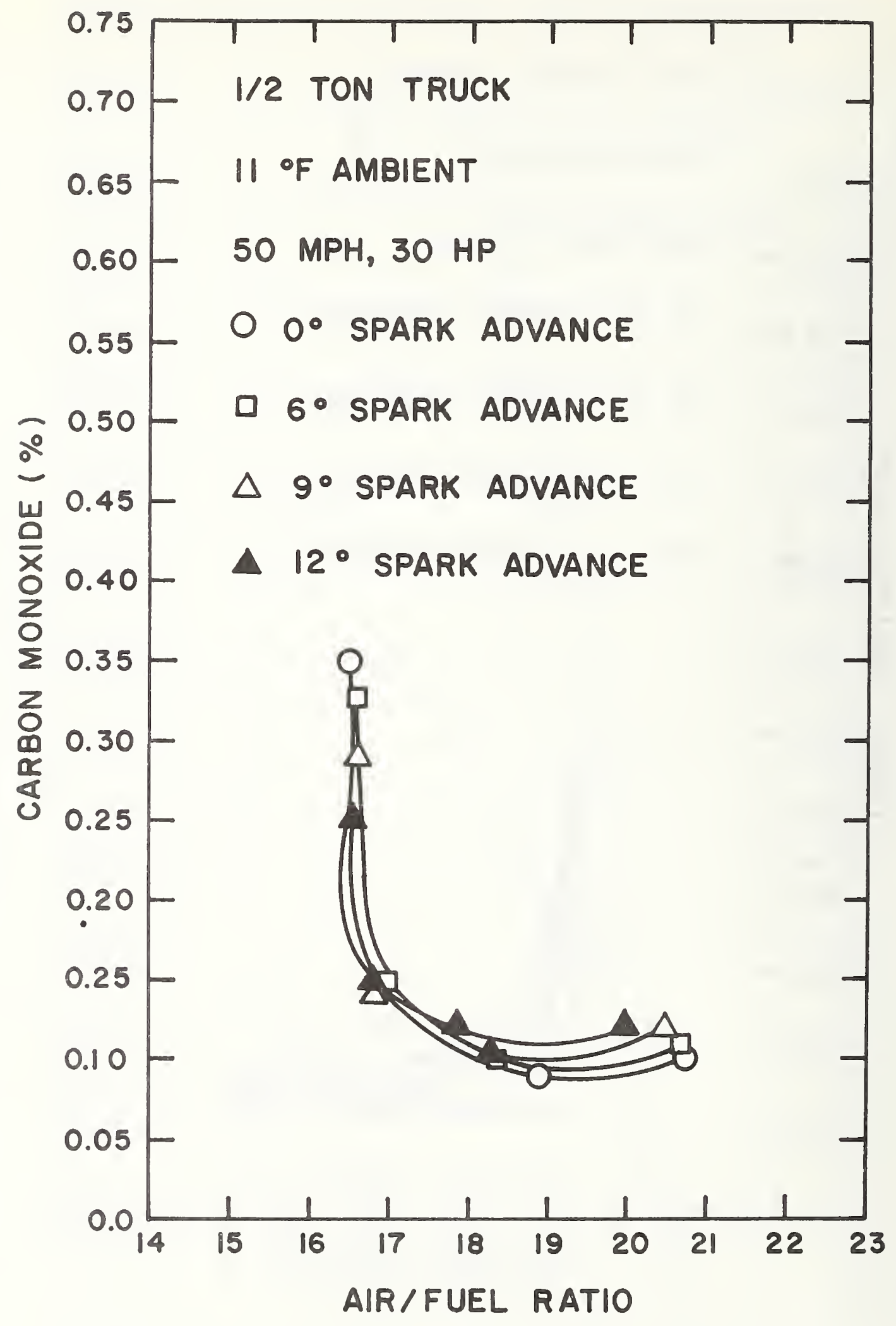

Figure 67 Carbon Monoxide Versus Air-Fuel Ratio for a $1 / 2$ Ton Truck Using LPG 


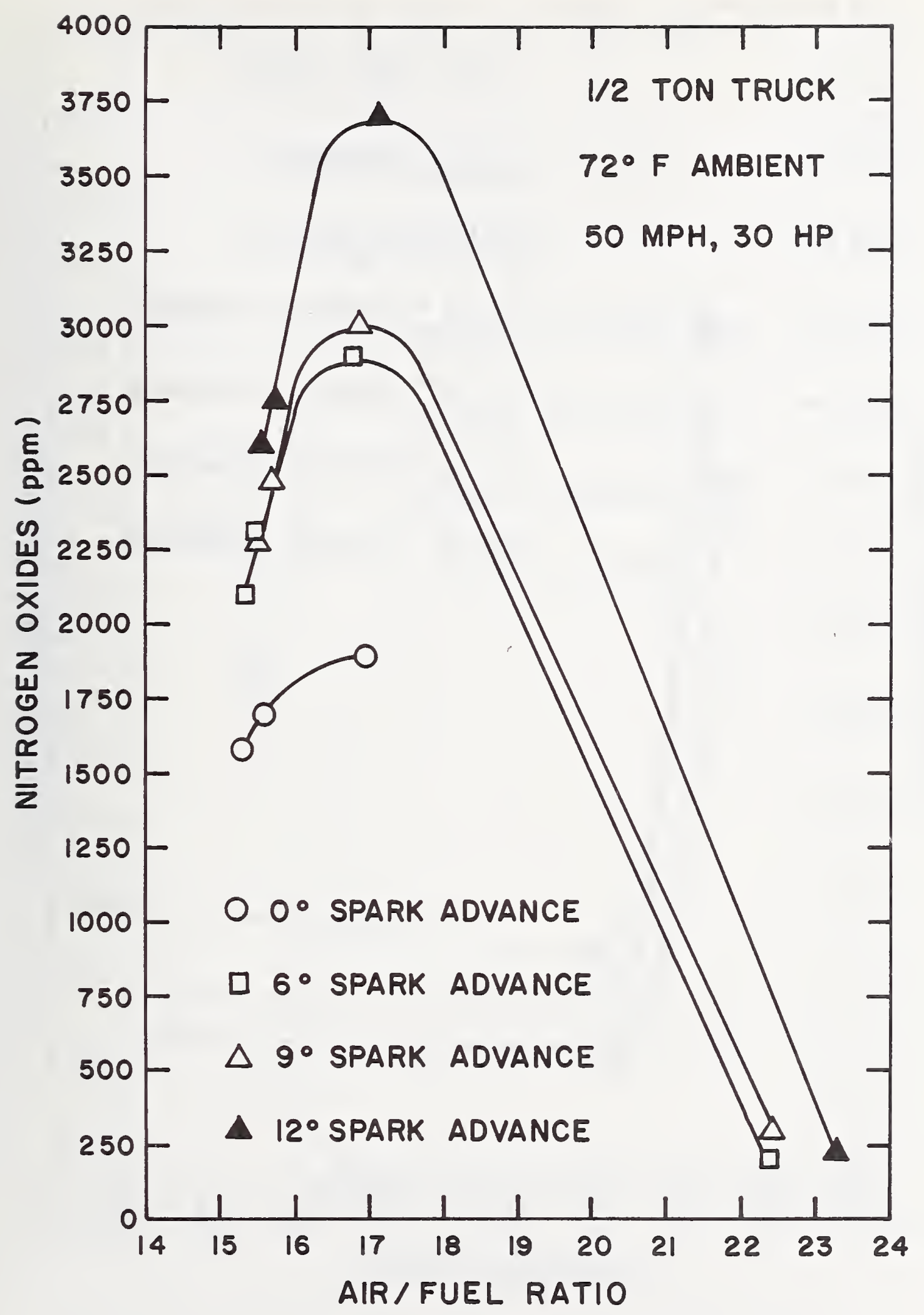

Figure 68 Nitrogen oxides Versus Air-Fuel Ratio for a $1 / 2$ Ton Truck Using LPG 


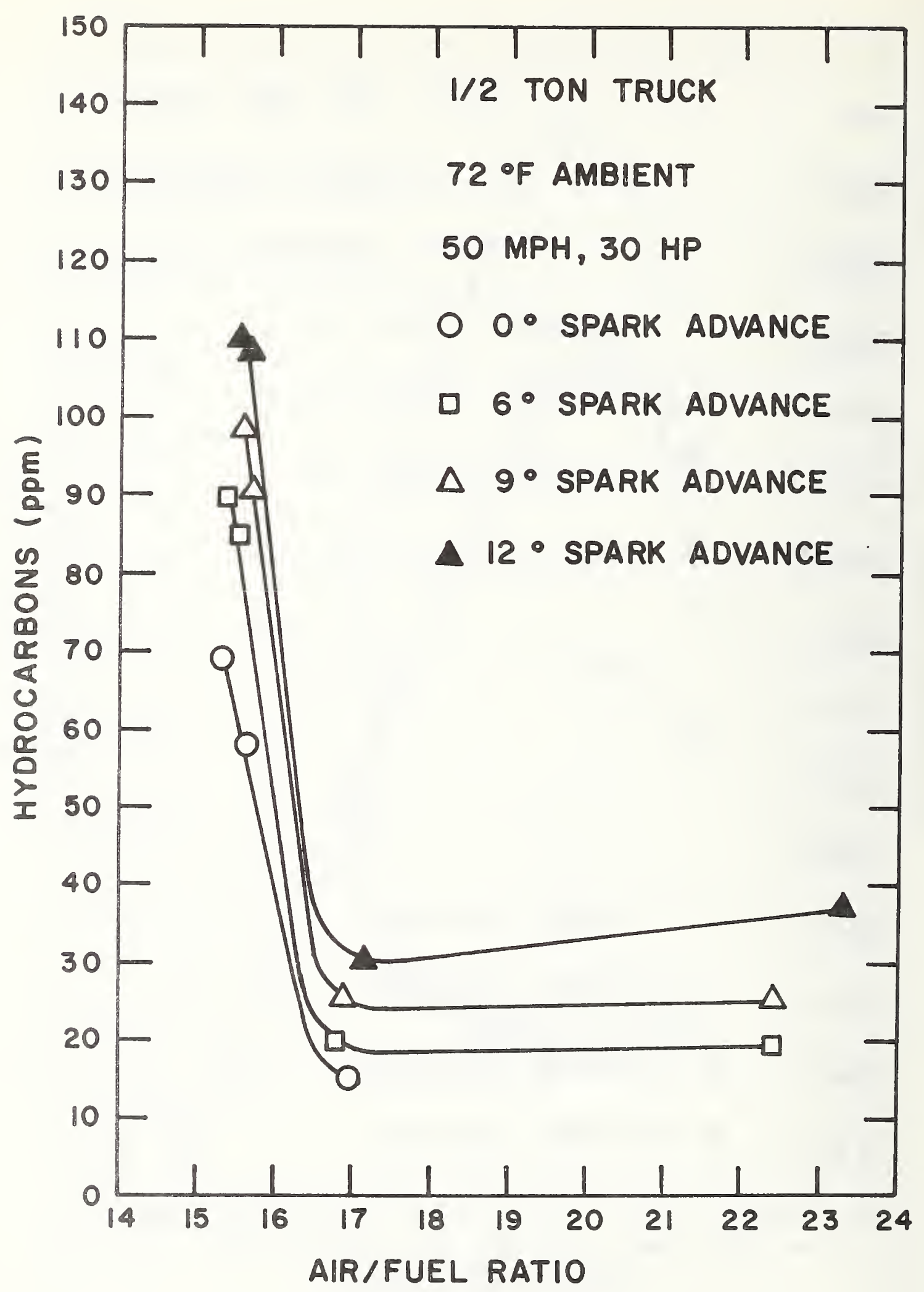

Figure 69 Hydrocarbons Versus Air-Fuel Ratio for a $1 / 2$ Ton Truck Using LPG 


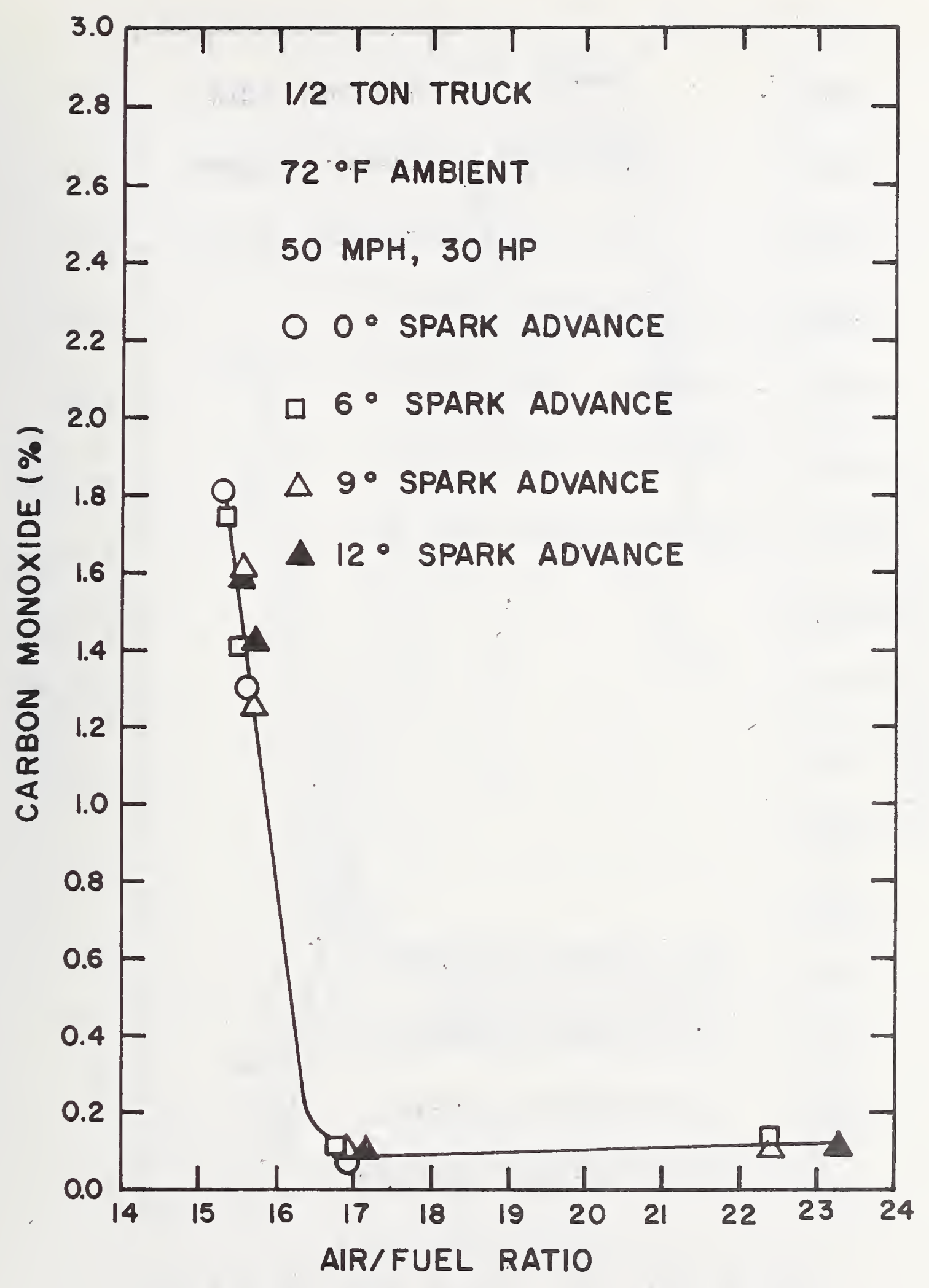

Figure 70 Carbon Monoxide Versus Air-Fuel Ratio for a $1 / 2$ Ton Truck Using LPG 


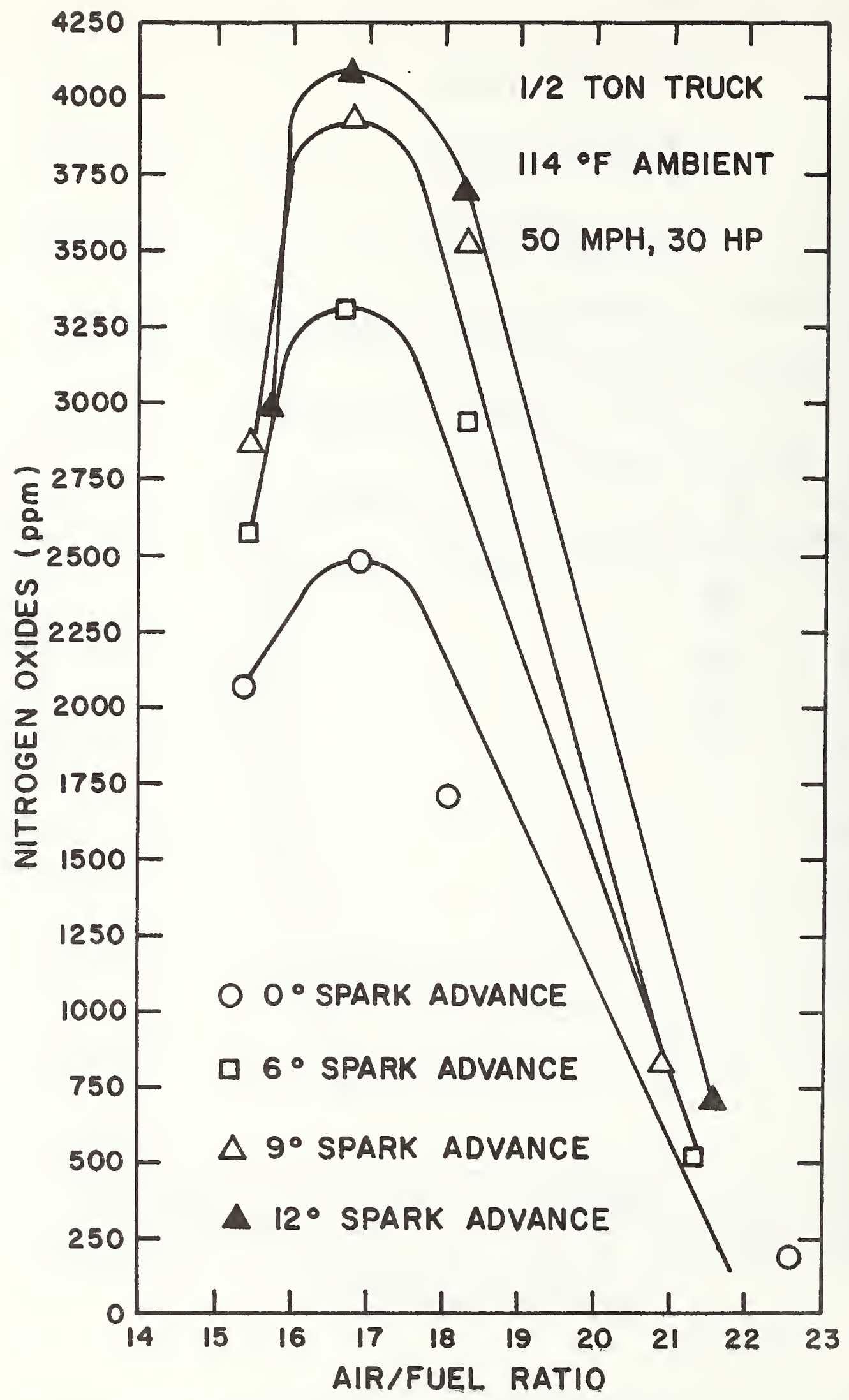

Figure 71 Nitrogen oxides Versus Air-Fuel Ratio for a 1/2 Ton Truck Using LPG 


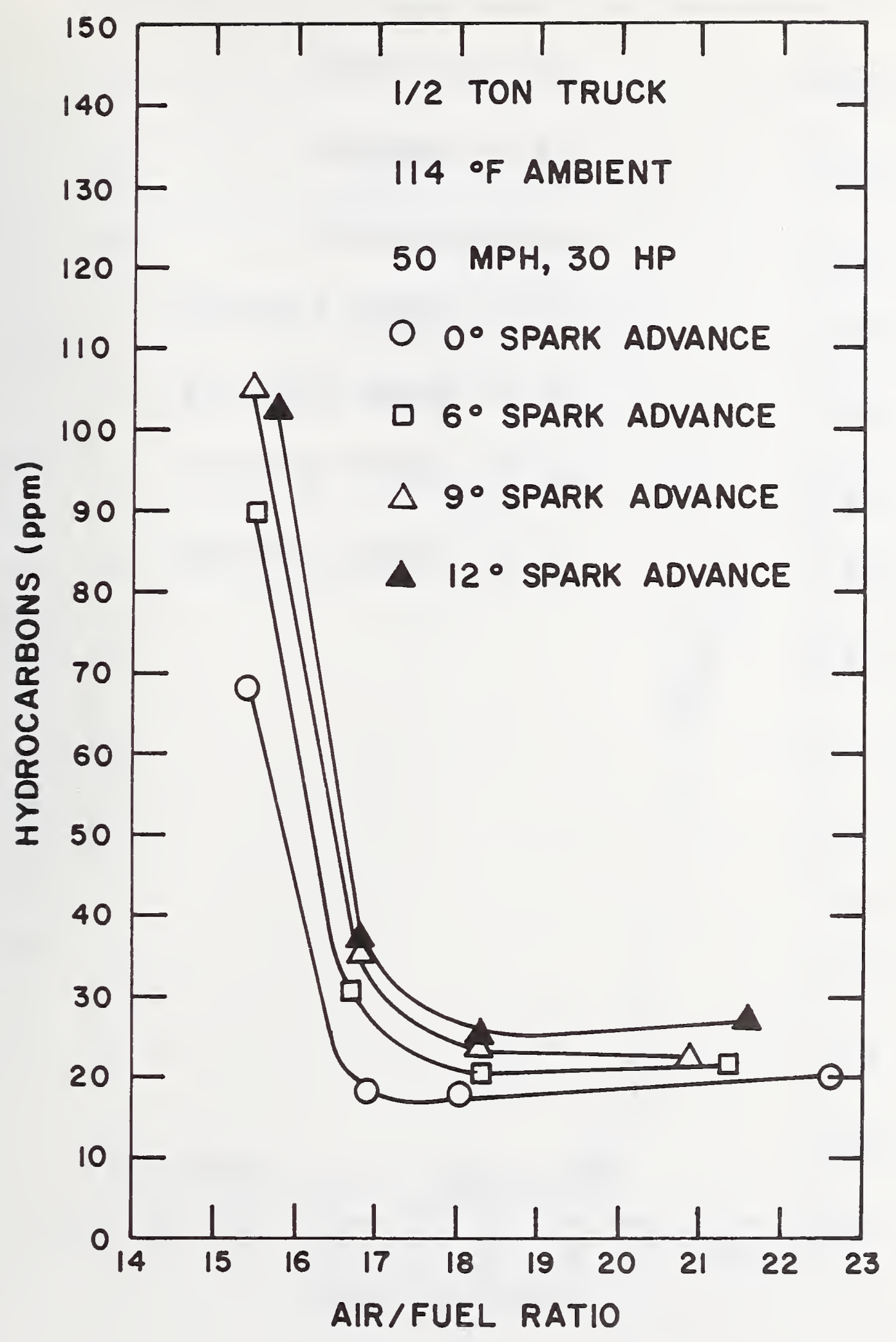

Figure 72 Hydrocarbons Versus Air-Fuel Ratio for a $1 / 2$ Ton Truck Using LPG 


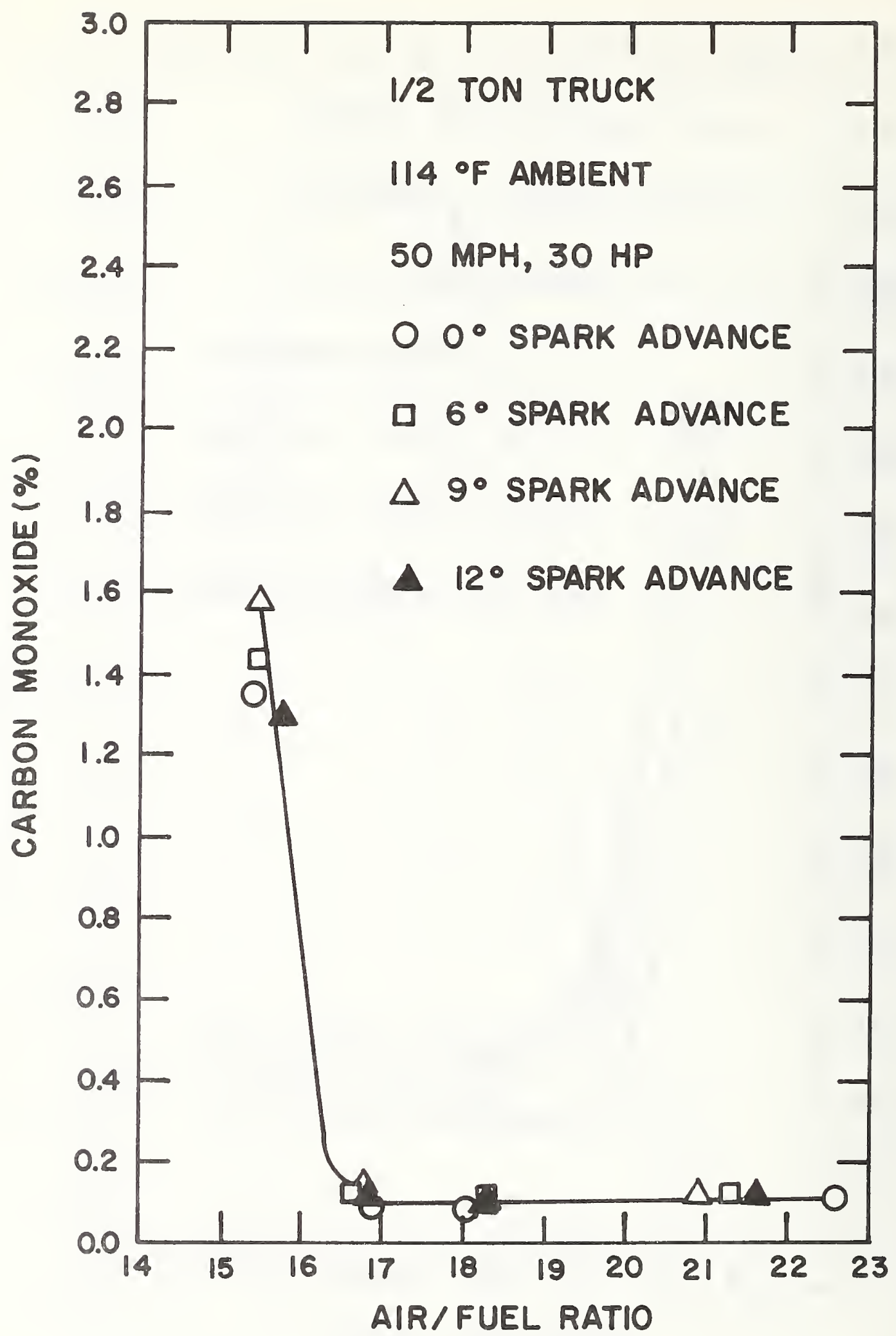

Figure 73 Carbon Monoxide Versus Air-Fuel Ratio for a $1 / 2$ Ton Truck Using LPG 
Figures 74,75 , and 76 show a comparison with ambient temperature of the data of the air-fuel ratio tests at the conditions of $50 \mathrm{mph}$ and $30 \mathrm{hp}$ and $6^{\circ}$ BTDC idling spark advance. The curves show that the $\mathrm{NO}_{\mathrm{x}}$ content of the exhaust gas increased slightly with ambient temperature and there was little or no variation with temperature in the $\mathrm{HC}$ and CO content. This is consistent with previous results for the vehicle fired on gasoline and CNG. One should be reminded that the nature of the tests are such that no choking occurred or warm-up period was allowed in the tests and comparisons were made for the same idling spark advance, air-fuel ratio, and running speed and load.

Figure 77 is a plot of the air-fuel ratio that resulted Erom a specific restrictor position setting at $6^{\circ}$ BTDC idling spark advance, $50 \mathrm{mph}$ and $30 \mathrm{hp}$ and the three different ambient temperatures. The setting was critical in the vicinity of the number 2 position in that a slight variation caused a considerable change in the resulting air-fuel ratio. However, the change in air-fuel ratio was slight once beyond the 3 position in the direction of a rich mixture. One can see that as the ambient temperature was lowered, the air-fuel ratio became leaner for a given power valve setting explaining why the valve position had to be moved to the $21 / 2$ position at the low temperature to obtain exactly 30 horsepower for all iding spark settings. Figure 77 could be used for estimating resulting air-fuel ratios at other idling spark settings by estimating 


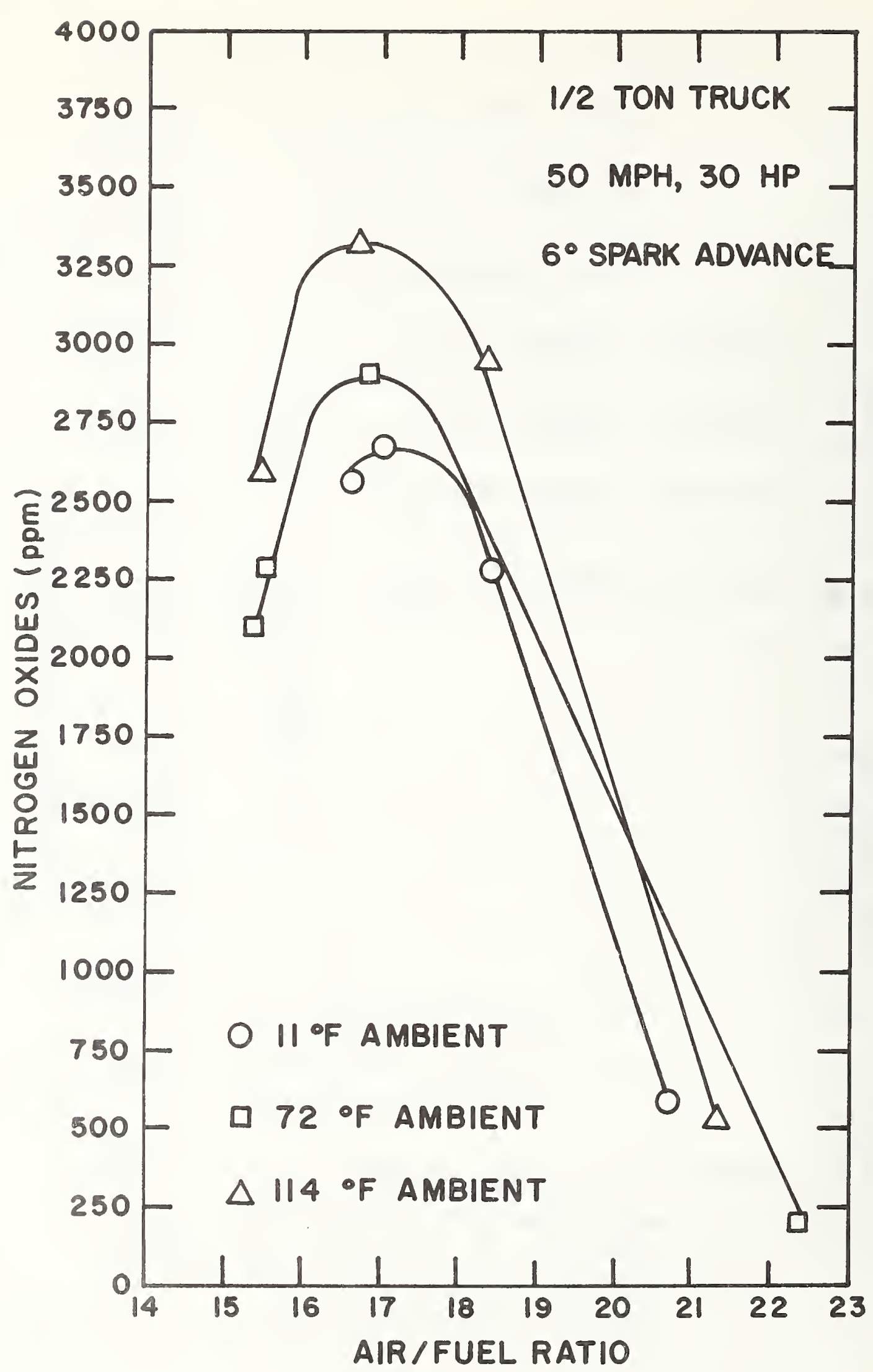

Figure 74 Nitrogen Oxides Versus Air-Fuel Ratio for a $1 / 2$ Ton Truck Using LPG 


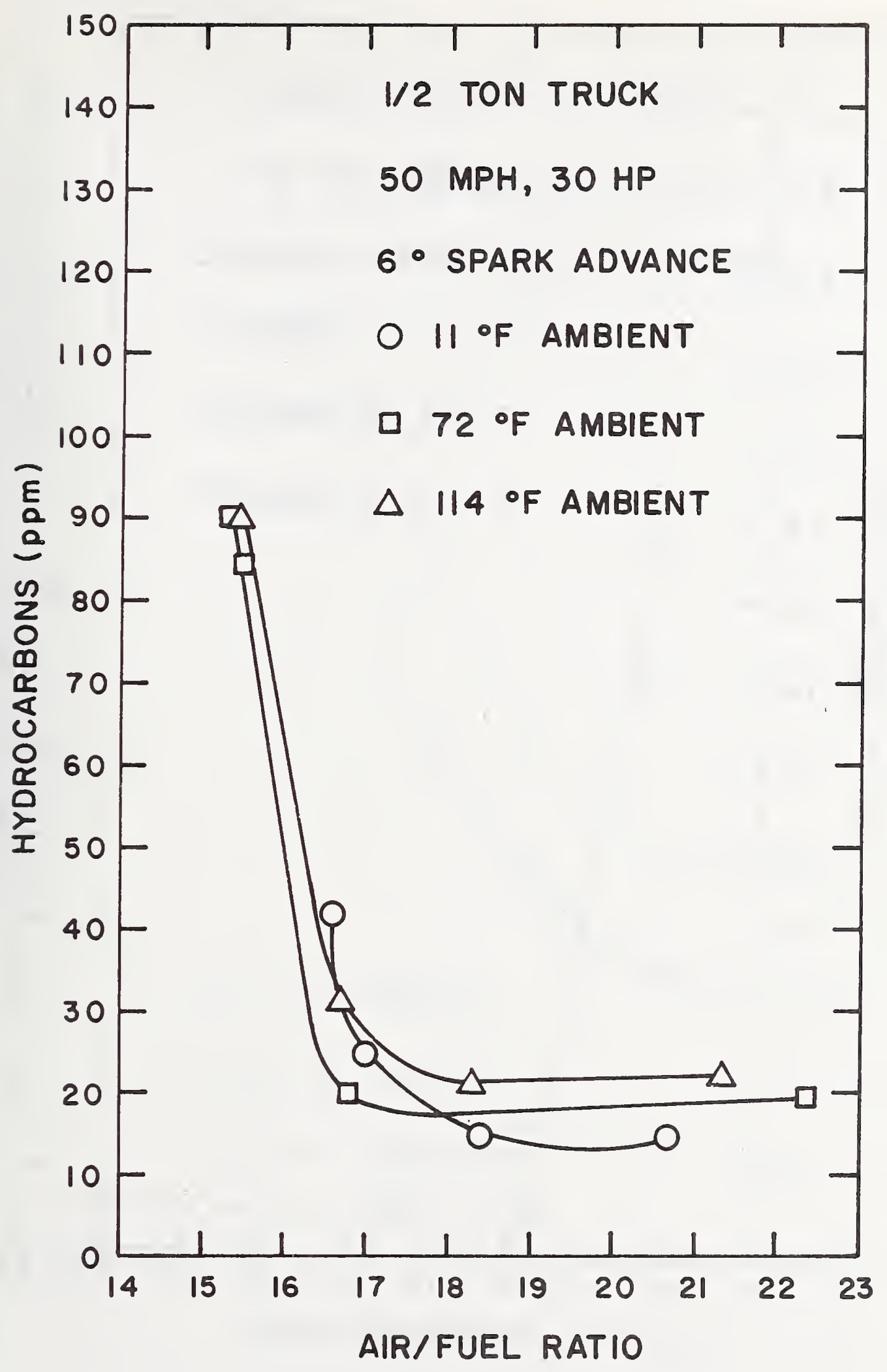

Figure 75 Hydrocarbons Versus Air-Fuel Ratio for a $1 / 2$ Ton Truck Using LPG 


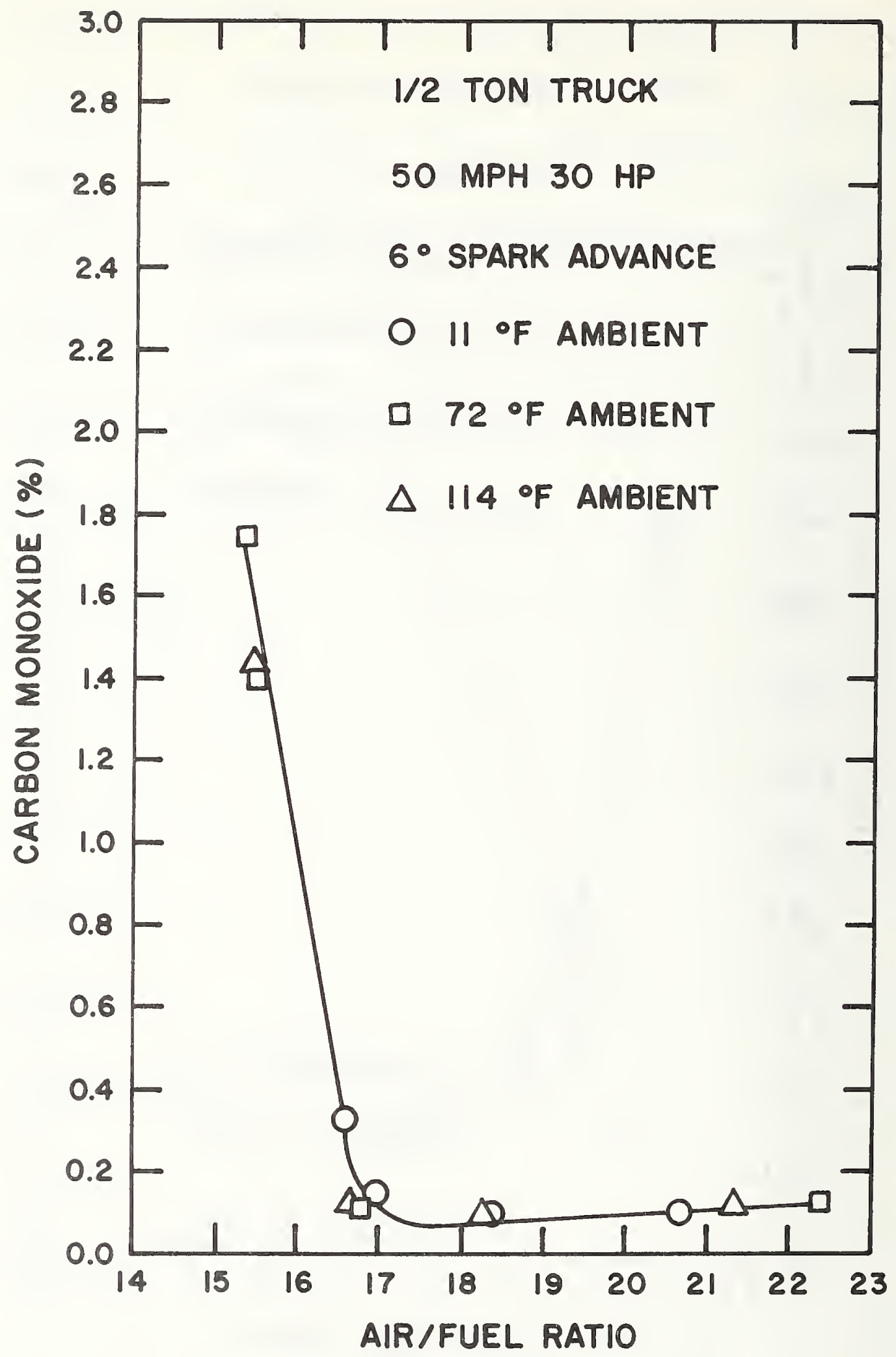

Figure 76 Carbon Monoxide Versus Air-Fuel Ratio for a $1 / 2$ Ton Truck Using LPG 


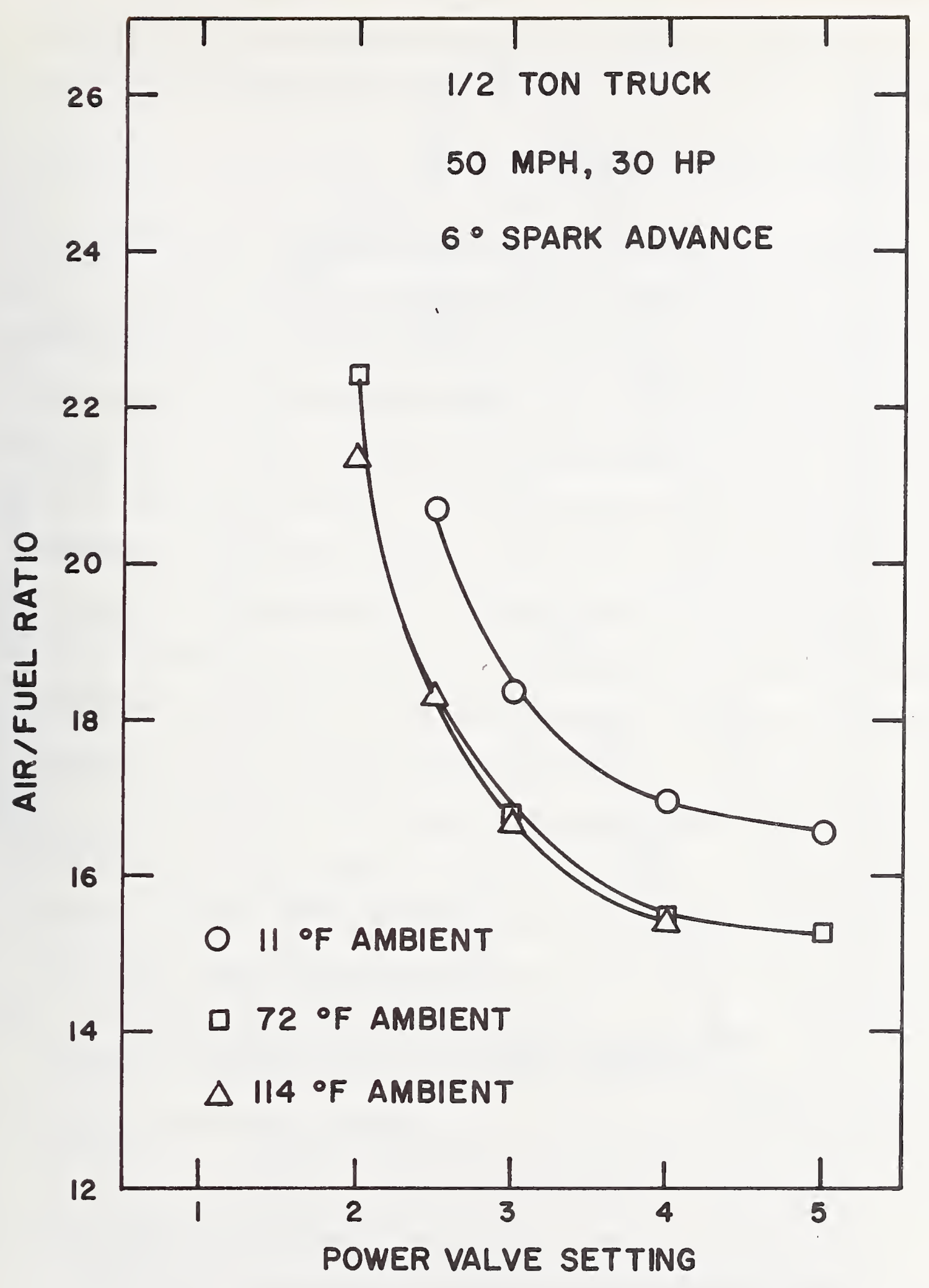

Figure 77 Air-Fuel Ratio Versus Power Valve Setting for a 1/2 Ton Truck Using LPG 
the change with idling spark setting from Figures 63 and 64 .

4.4 Comparison of the Fue 1s

Figures 78 through 86 have been inserted to show a comparison between CNG and LPG as fuels for this $1 / 2$ ton truck. The comparison is made for $50 \mathrm{mph}$ and $30 \mathrm{hp}$, and a given iding spark setting with the independent variable being the ratio of air-fuel ratio to stoichiometric air-fuel ratio. Data is shown for low temperature (Figures 78, 79, and 80), moderate temperature (Figures 81,82 , and 83), and high temperature (Figures 84, 85, and 86). The $\mathrm{NO}_{\mathrm{x}}$ content of the exhaust gas was a maximum closer to stoichiometric conditions for CNG than for LPG (for all ambient temperatures $11^{\circ} \mathrm{F}-114^{\circ} \mathrm{F}$ ) and consequently for a given value of A/F/(A/F stoichiometric) > 1.0, the No $_{x}$ content of the LPG exhaust gas was higher than that of the CNG exhaust gas. As the mixture was enriched from a lean setting towards the stoichiometric condition, the CO and HC content of the exhaust gas did not rise significantly for CNG-fired tests until conditions to the rich side of stoichiometric were reached (all ambient temperatures). However, the increase occurred to the lean side of stoichiometric for the LPG-fired tests (all ambient temperatures).

Figures 87 through 95 show the comparison of fuels for this $1 / 2$ ton truck on another basis. The independent variable is the idling spark advance and data is shown for $\mathrm{NO}_{\mathrm{x}}$ at $50 \mathrm{mph}$ 


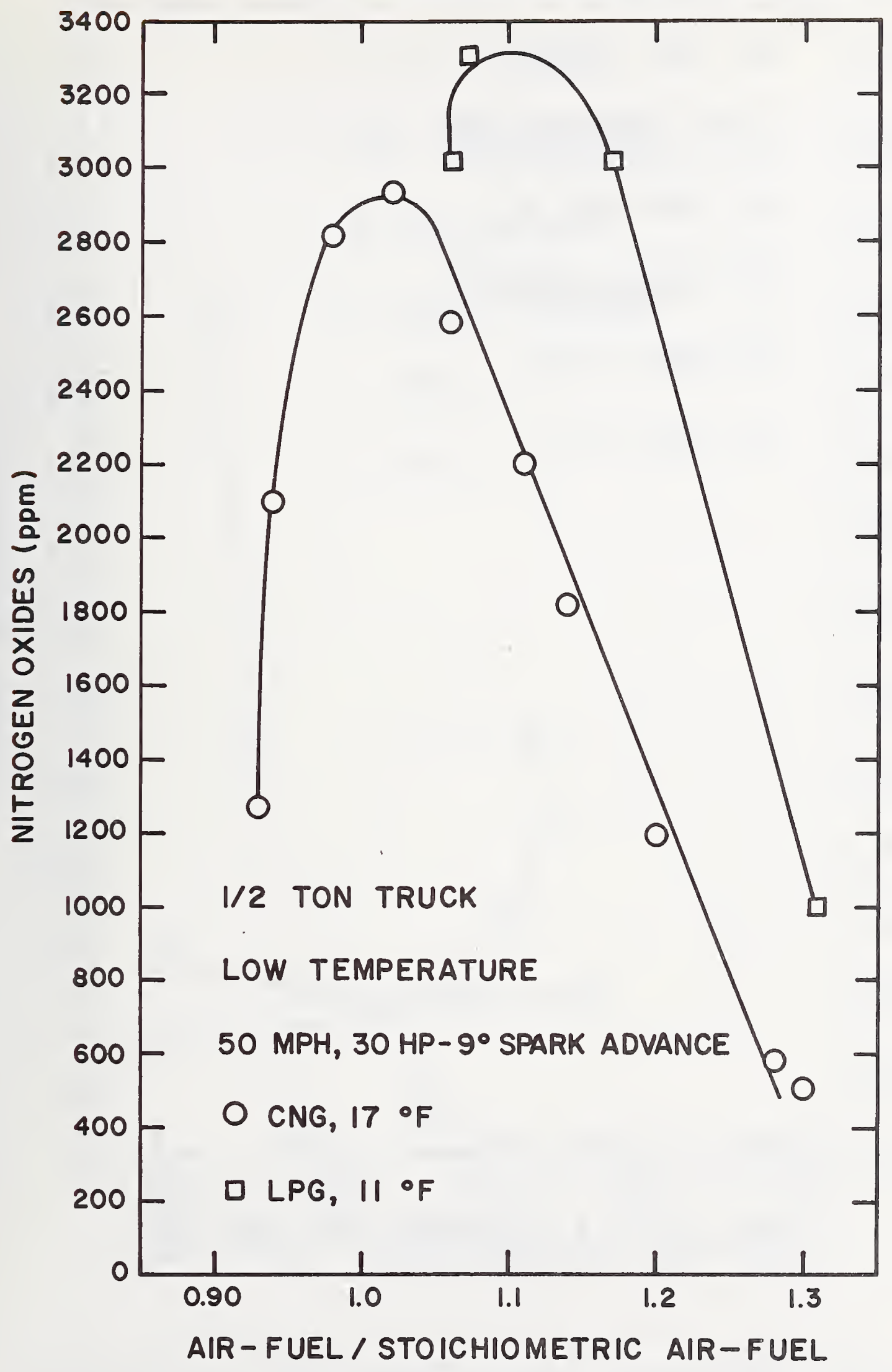

Figure 78 Nitrogen Oxides Versus Normalized Air-Fuel Ratio for a $1 / 2$ Ton Truck Using CNG and LPG 


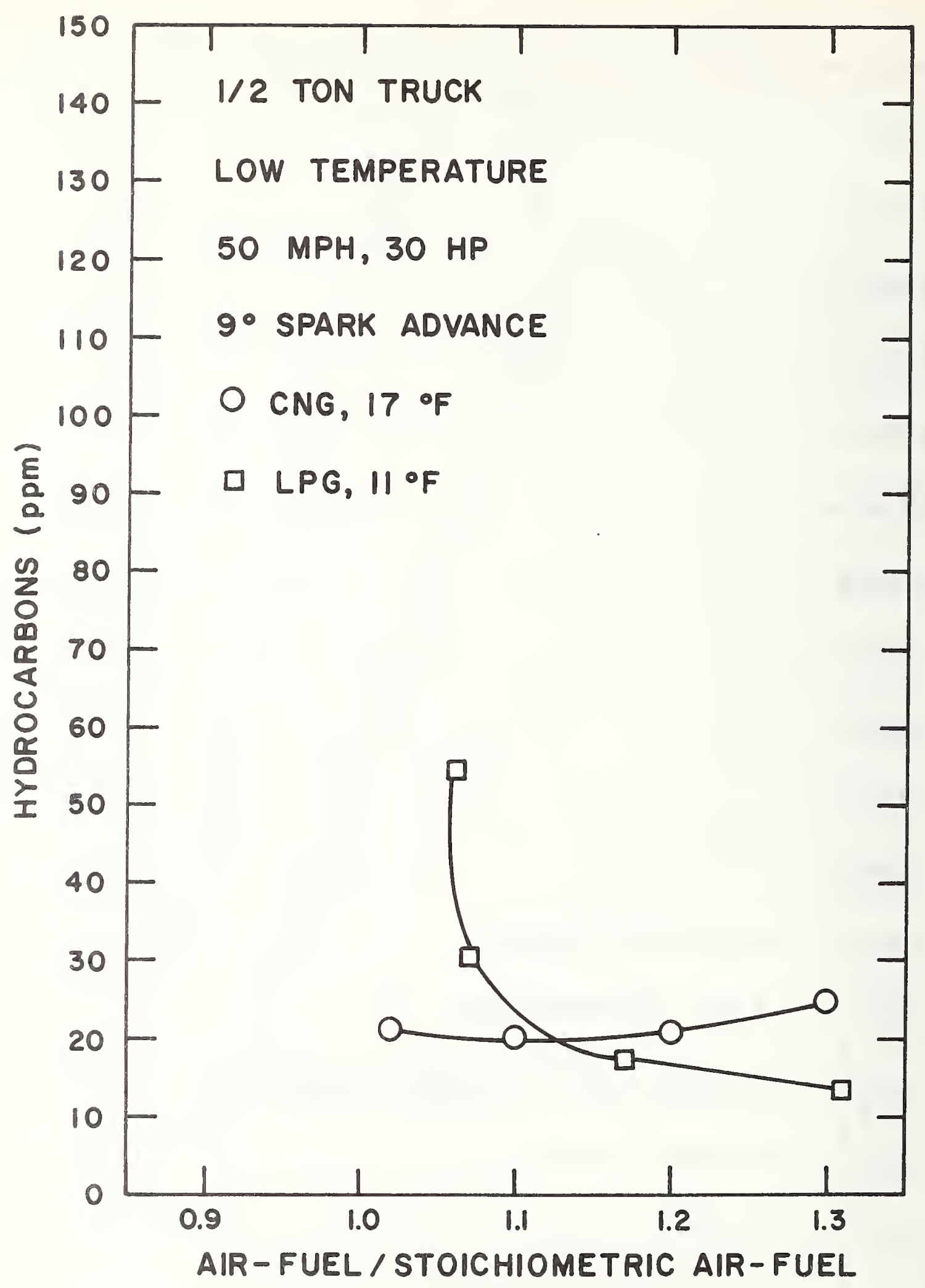

Figure 79 Hydrocarbons Versus Normalized Air-Fue1 Ratio for a $1 / 2$ Ton Truck Using CNG and LPG 


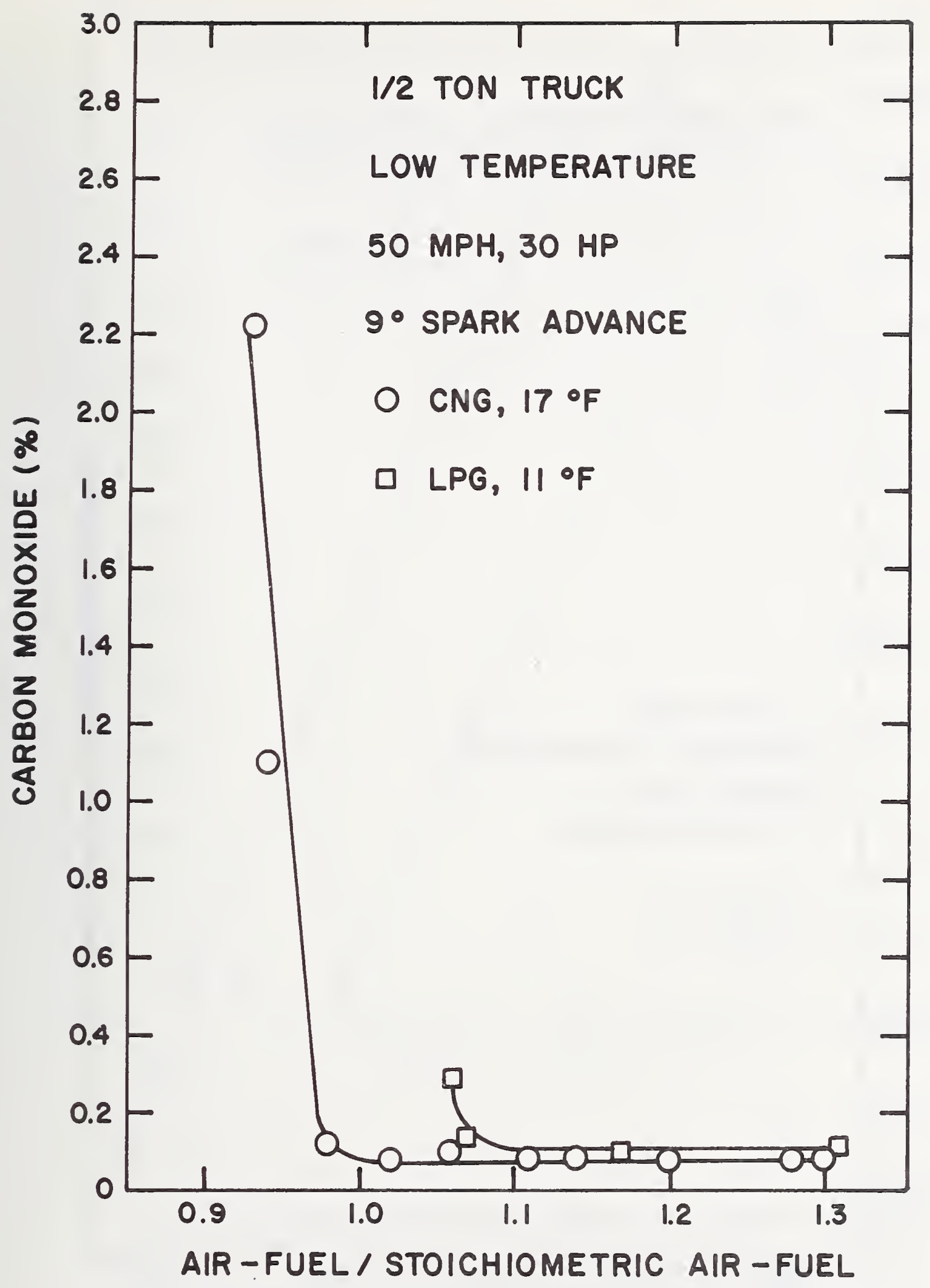

Figure 80 Carbon Monxoide Versus Normalized Air-Fuel Ratio for a $1 / 2$ Ton Truck Using $C N G$ and LPG 


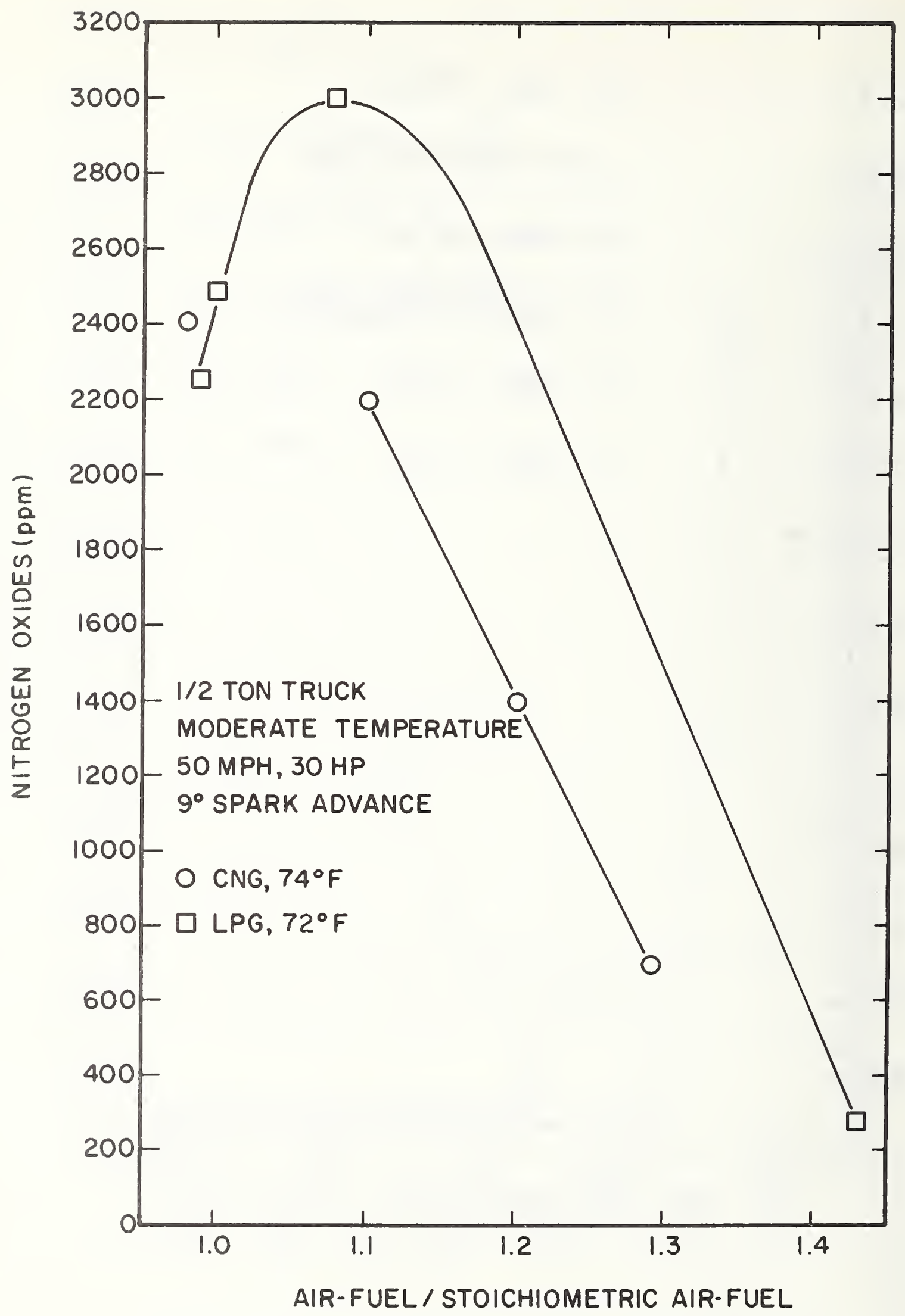

Eigure 81 Nitrogen Oxides Versus Normalized Air-Fuel Ratio for a $1 / 2$ Ton Truck Using CNG and LPG 


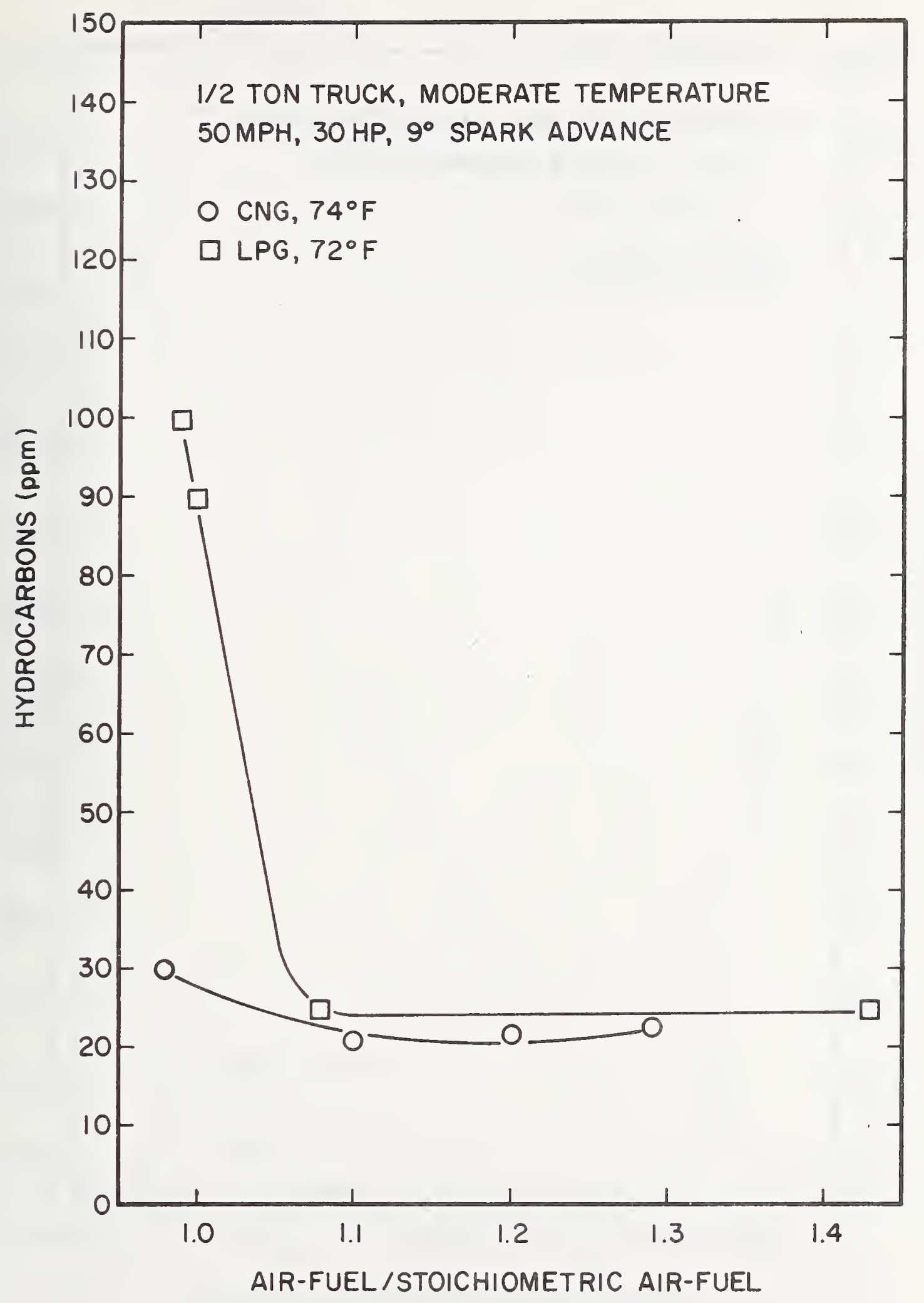

Figure 82 Hydrocarbons Versus Normalized Air-Fuel Ratio for a $1 / 2$ Ton Truck Using CNG and LPG 


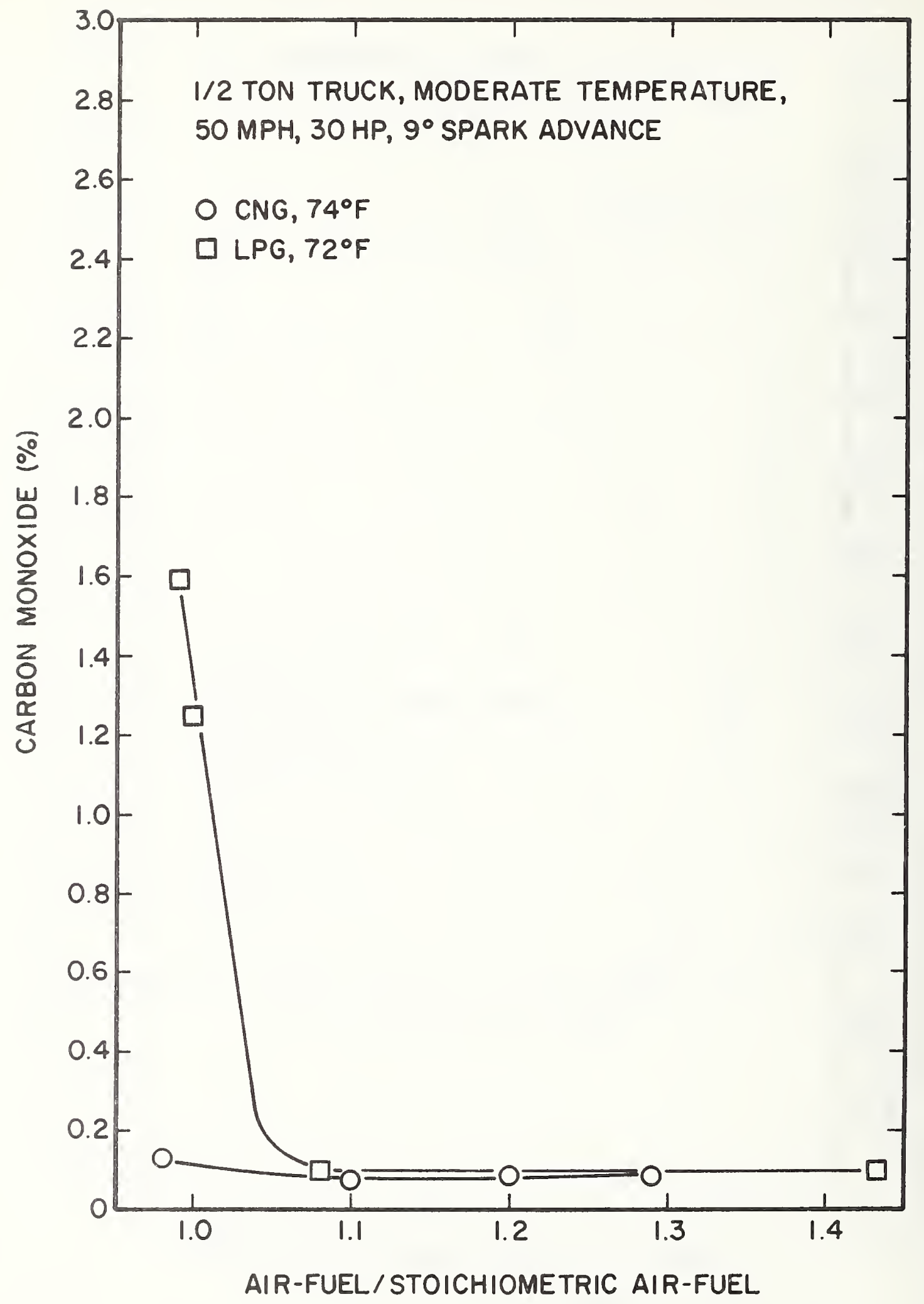

Figure 83 Carbon Monoxide Versus Normalized Air-Fuel Ratio for a 1/2 Ton Truck Using CNG and LPG 


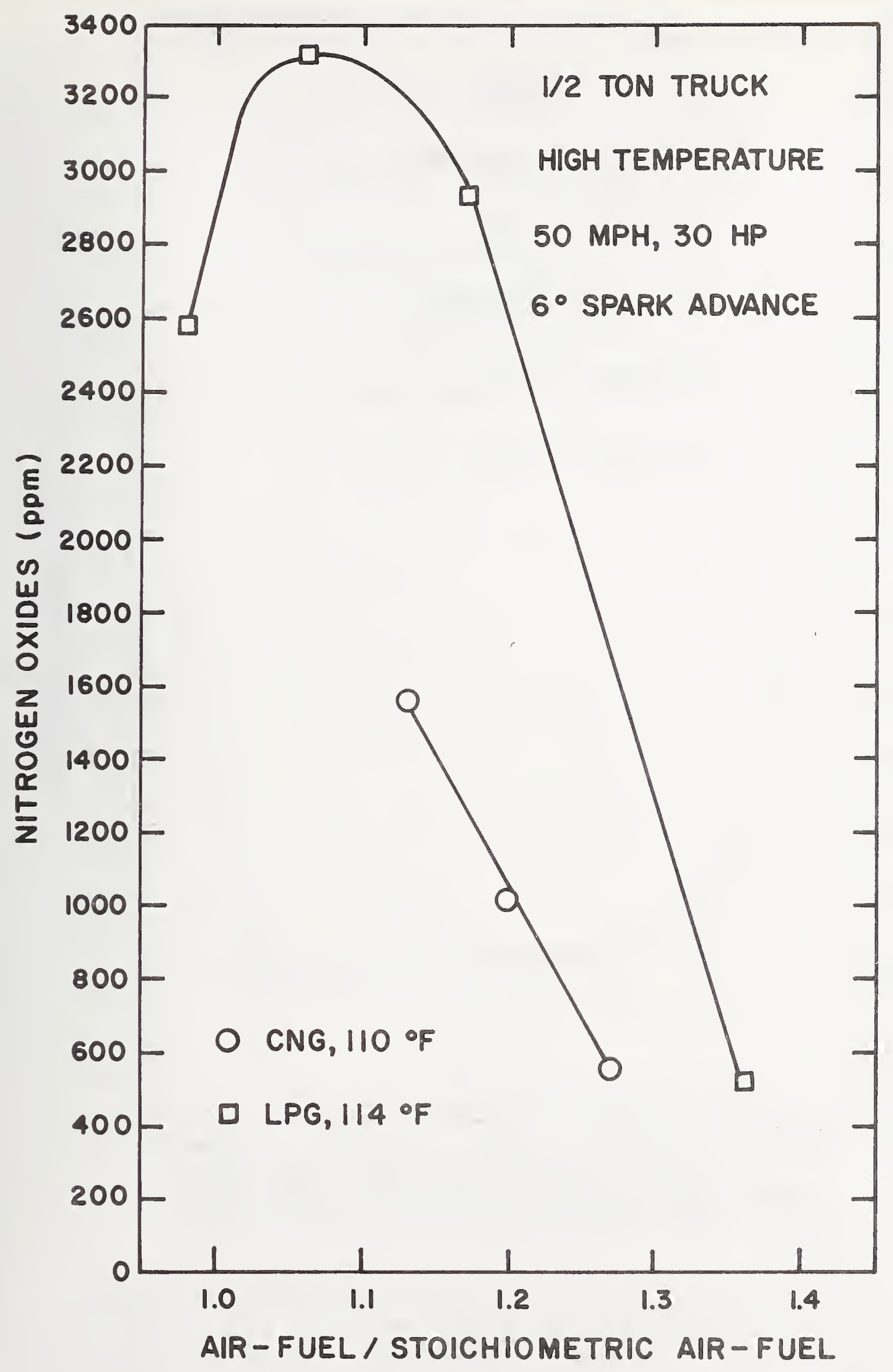

Figure 84 Nitrogen Oxides Versus Normalized Air-Fuel Ratio for a $1 / 2$ Ton Truck Using CNG and LPG 


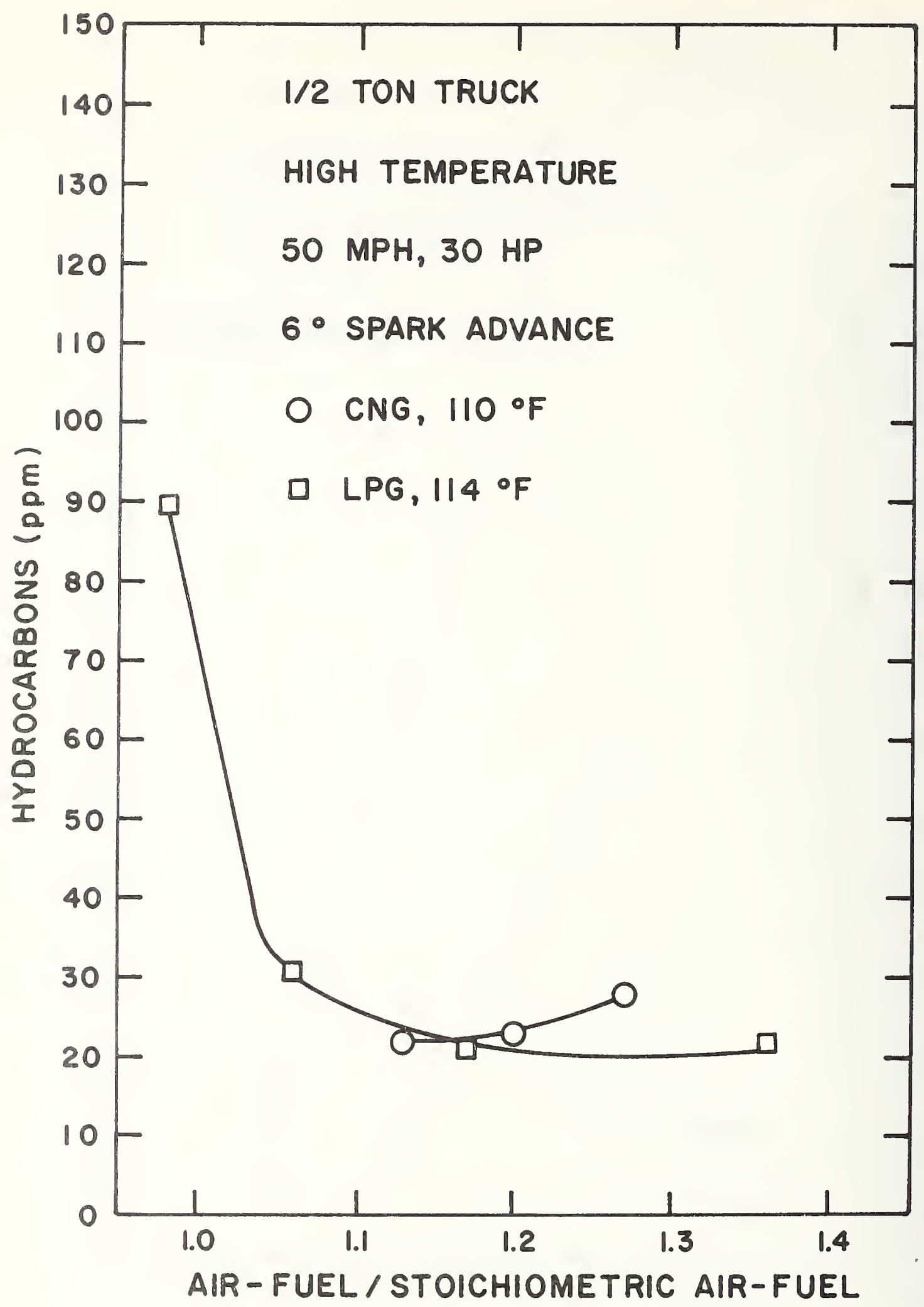

Figure 85 Hydrocarbons Versus Normalized Air-Fuel Ratio for a $1 / 2$ Ton Truck Using CNG and LPG 


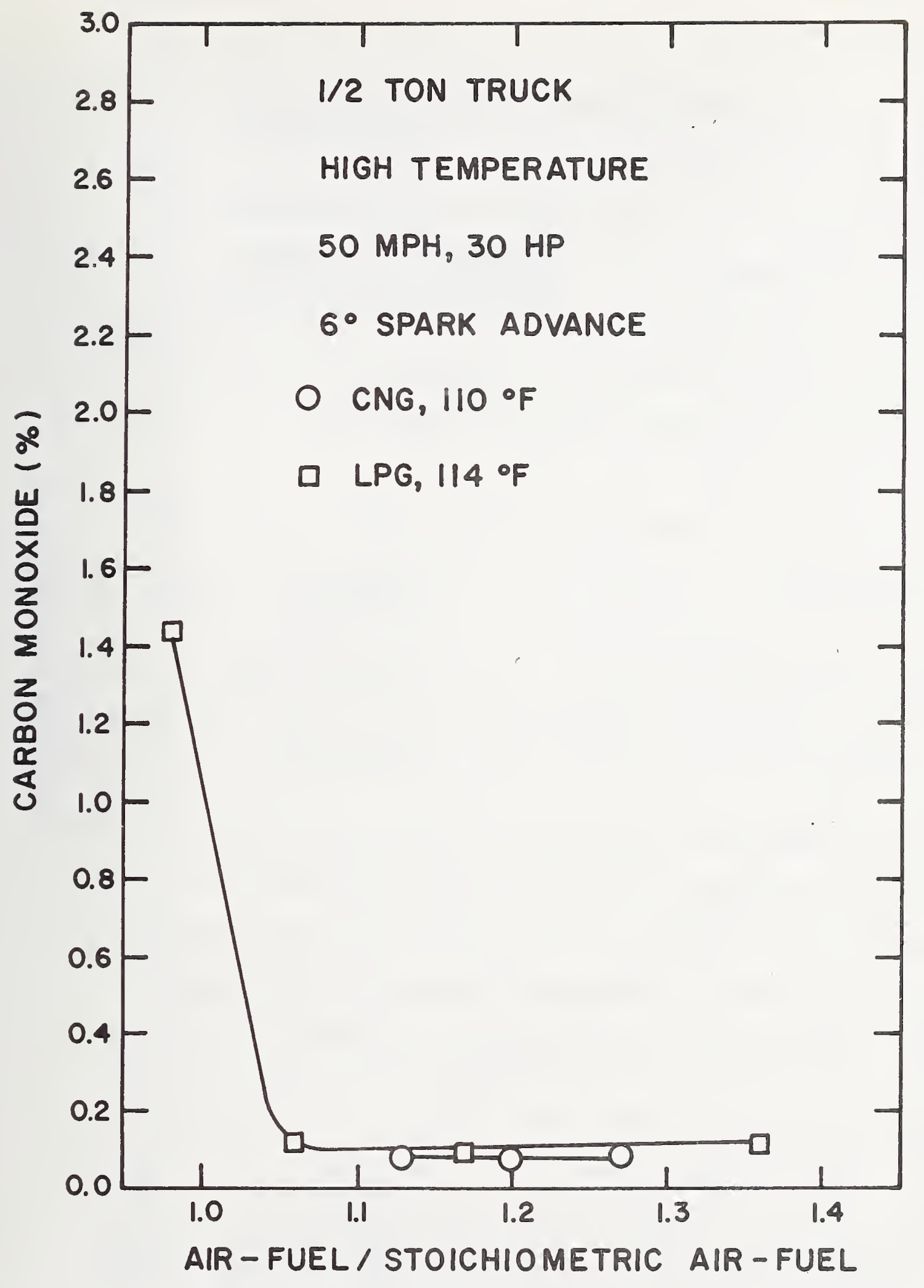

Figure 86 Carbon Monoxide Versus Normalized Air-Fuel Ratio for a $1 / 2$ T॰n Truck Using CNG and LPG 
and $30 \mathrm{hp}$ and three temperature levels (Figures 87, 90, and 93) and $\mathrm{HC}$ and $\mathrm{CO}$ at idling conditions in Figures 88,91 , and 94 and Figures 89,92 , and 95 respectively. In contrast to Figures 78 through 86 , the comparison is not made on the basis of the same air-fuel ratio; however the data is shown for each fuel where the leanest setting possible was used (and still obtain $30 \mathrm{hp}$ at $50 \mathrm{mph}$ ). Those settings were:

$$
\text { gasoline }
$$

low temperature

preset

moderate temperature preset

high temperature

preset
CNG

1. $5^{\prime \prime}$ idle gas pressure 1. $5^{\prime \prime}$ idle gas pressure

1. $5^{\prime \prime}$ idle gas pressure
LPG

$21 / 2$ power valve setting

2 power valve setting

2 power valve setting

One can see from the curves that it was possible to maintain the various pollutants below the following levels for an appropriate lean setting in the fuel system (no adjustment for gasoline) and the following idling spark settings for ambient temperatures in the range $\left(0-110^{\circ} \mathrm{F}\right)$ :

$6^{\circ}$ BTDC idling spark advance

$$
\mathrm{NO}_{\mathrm{X}}(\mathrm{ppm})
$$

CNG 300

gasoline
$\mathrm{HC} \quad(\mathrm{ppm})$

50

215
$\mathrm{CO}(\%)$

0.1

1.2 


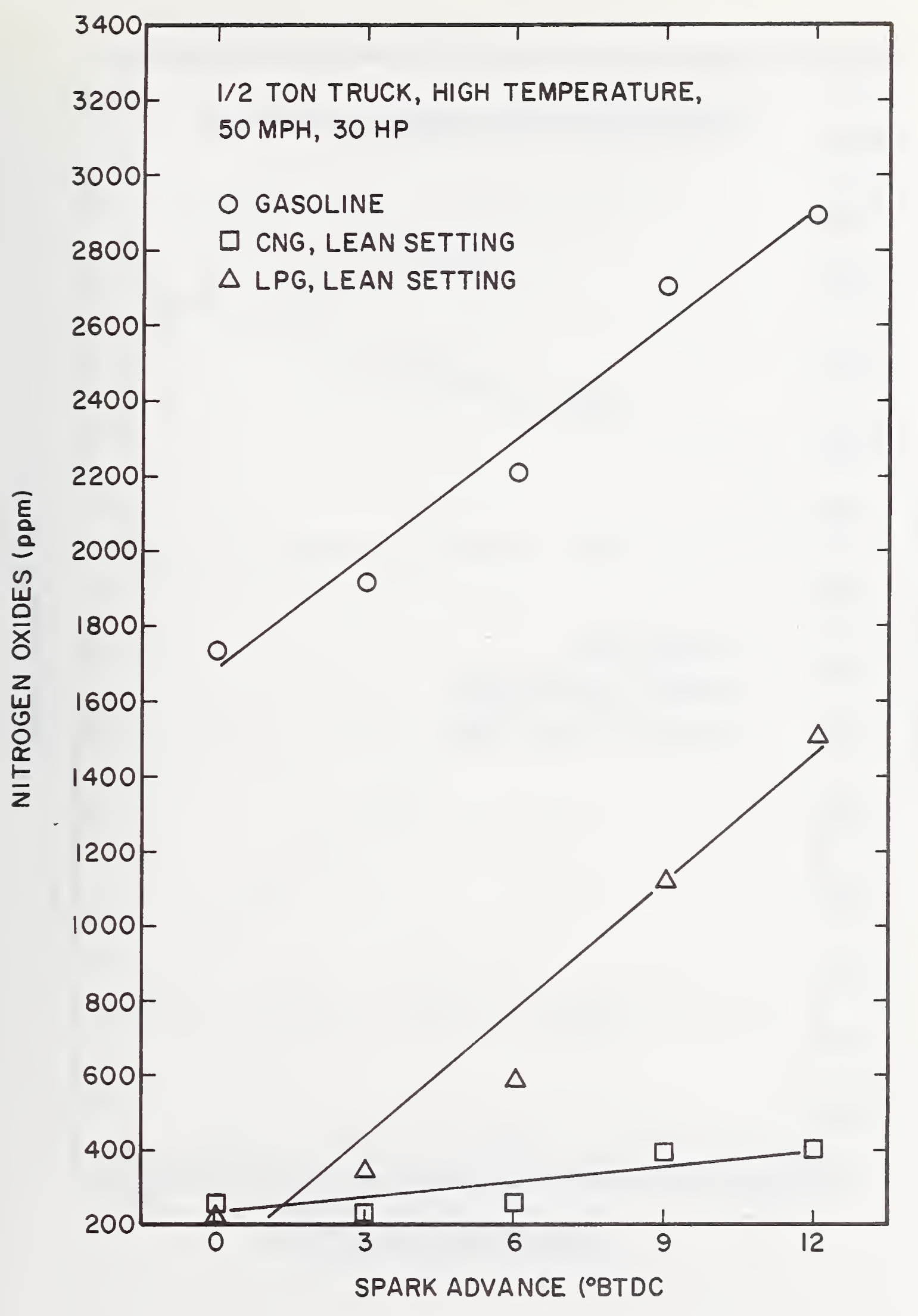

Figure 87 Nitrogen Oxides Versus Spark Advance for a $1 / 2$ Ton Truck Using Gasoline, CNG and LPG 


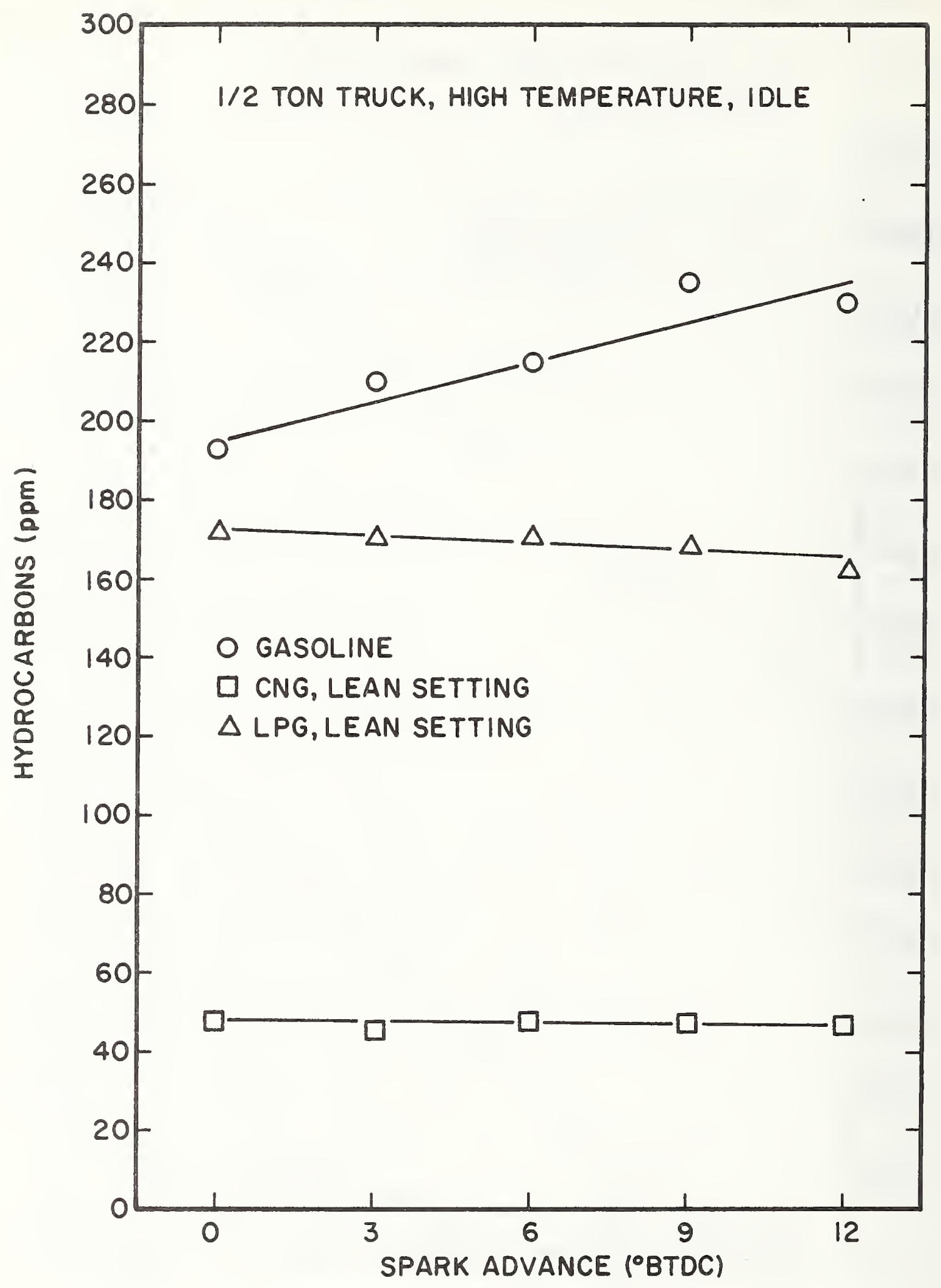

Figure 88 Hydrocarbons Versus Spark Advance for a $1 / 2$ Ton Truck Using Gasoline, CNG and LPG 


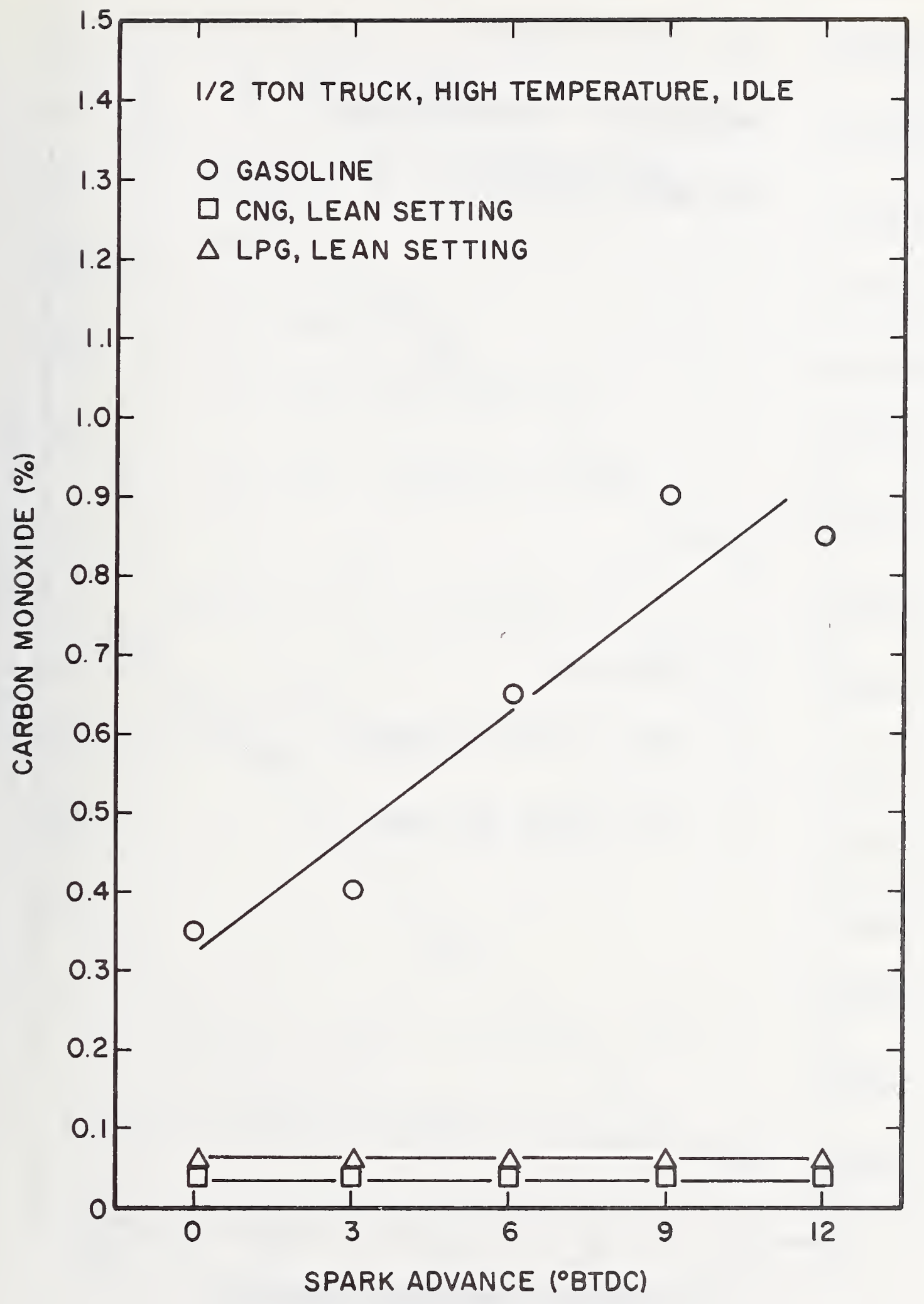

Figure 89 Carbon Monoxide Versus Spark Advance for a $1 / 2$ Ton Truck Using Gasoline, CNG and LPG 


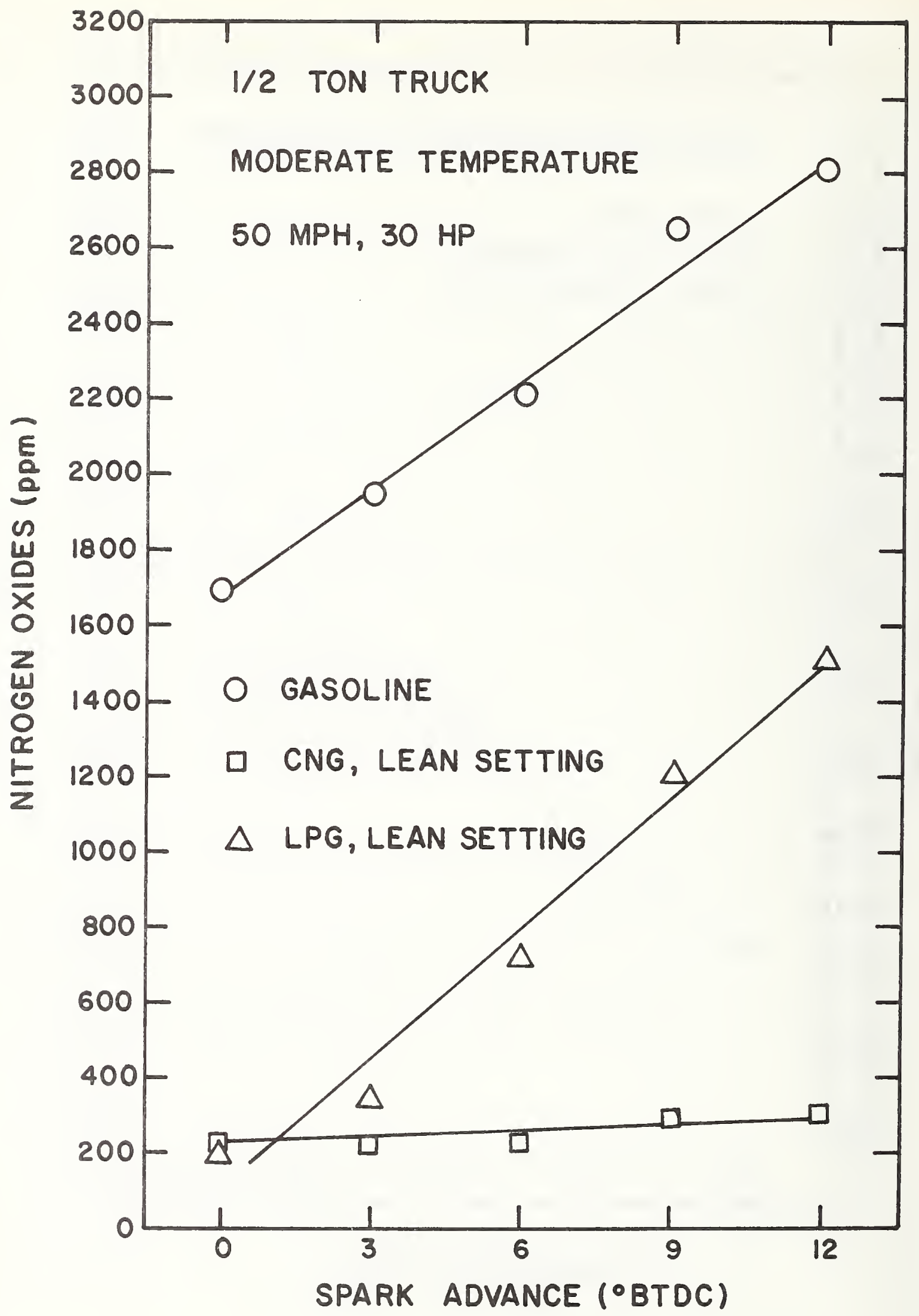

F1gure 90 Nitrogen Oxides Versus Spark Advance for a $1 / 2$ Ton Truck Using Gasoline, CNG and LPG 


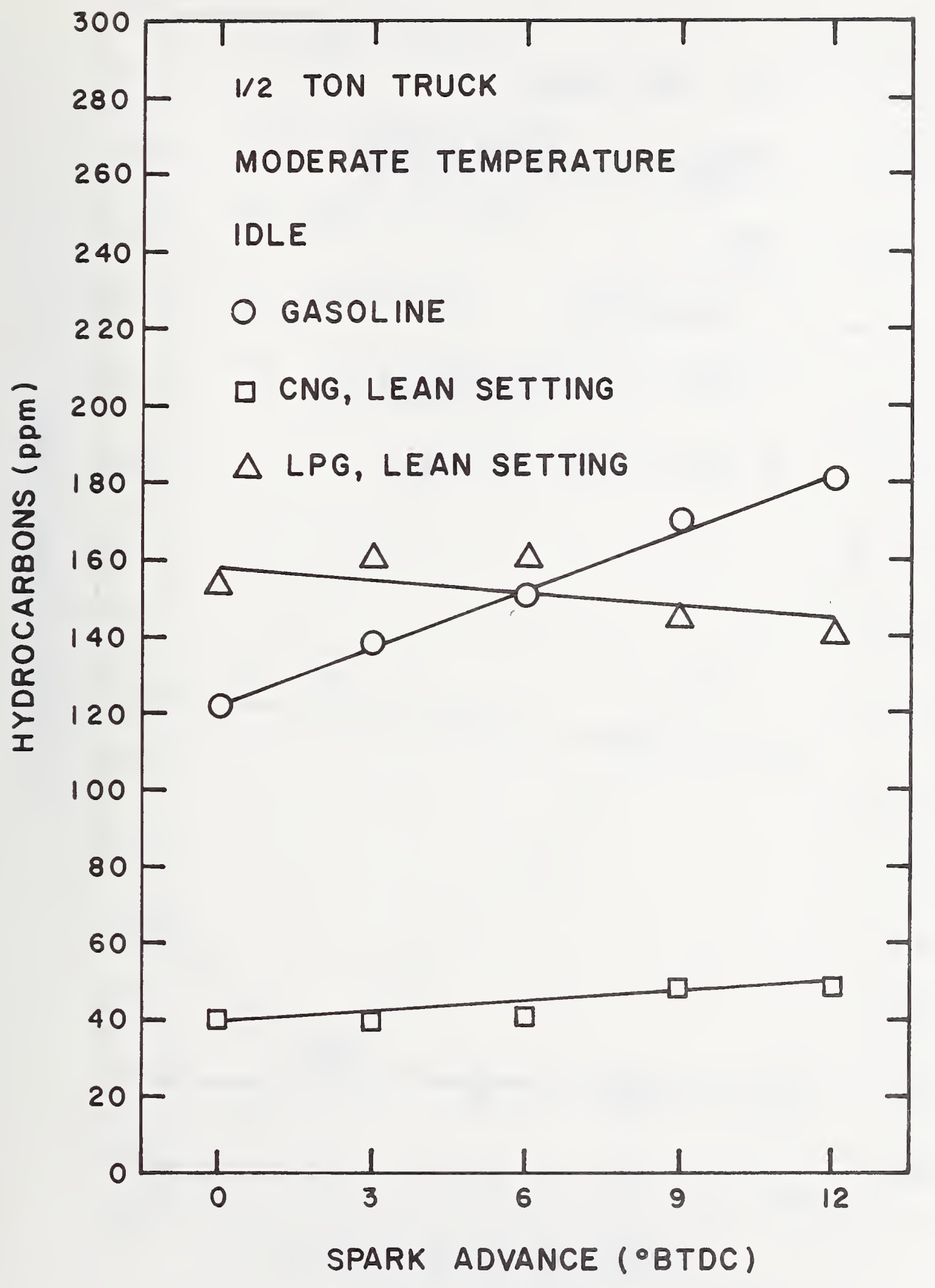

Figure 91 Hydrocarbons Versus Spark Advance for a $1 / 2$ Ton Truck Using Gasoline, CNG and LPG 


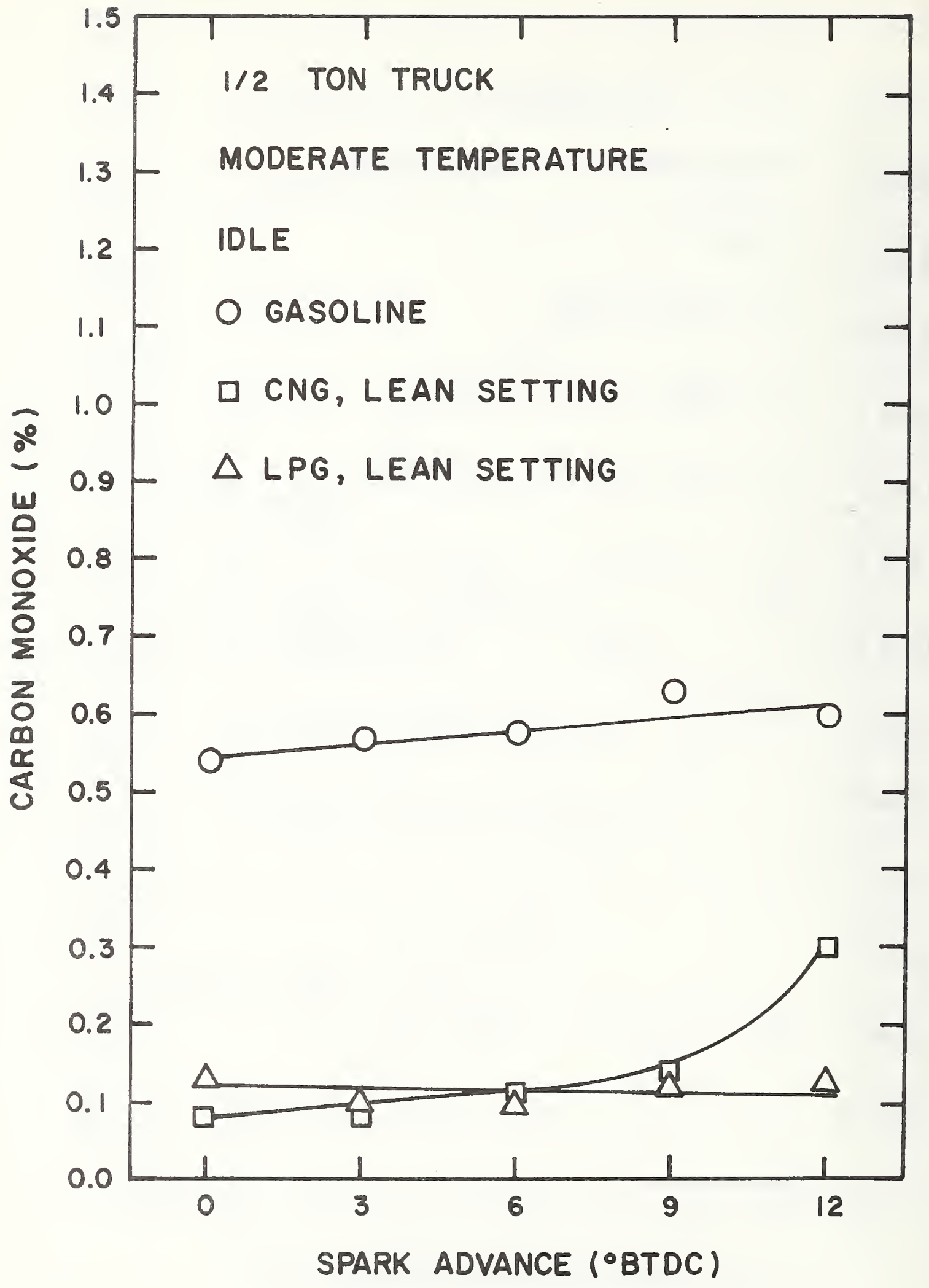

Figure 92 Carbon Monoxide Versus Spark Advance for a $1 / 2$ Ton Truck Using Gasoline, CNG and LPG 


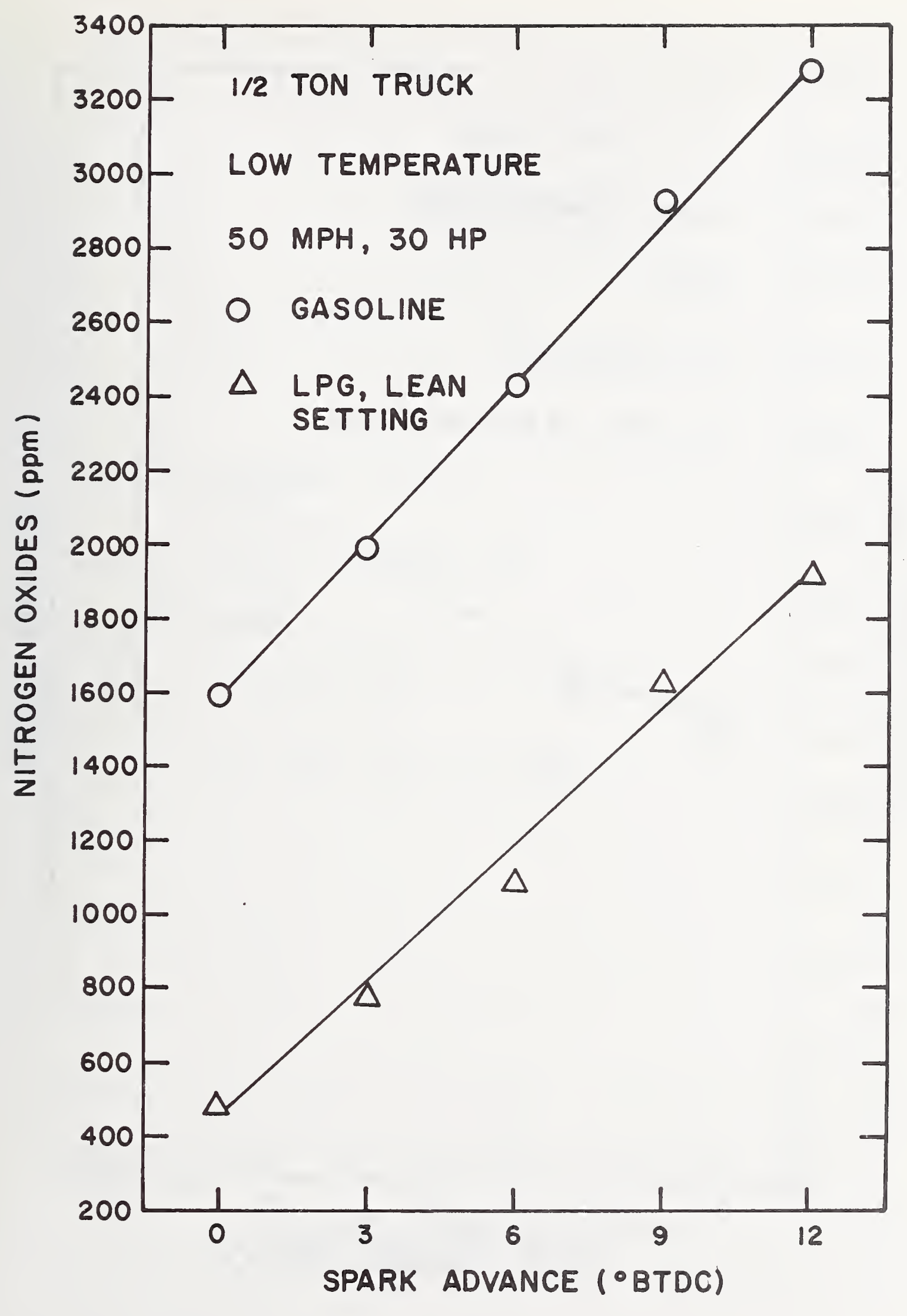

Figure 93 Nitrogen Oxides Versus Spark Advance for a $1 / 2$ Ton Truck Using Gasoline, and LPG 


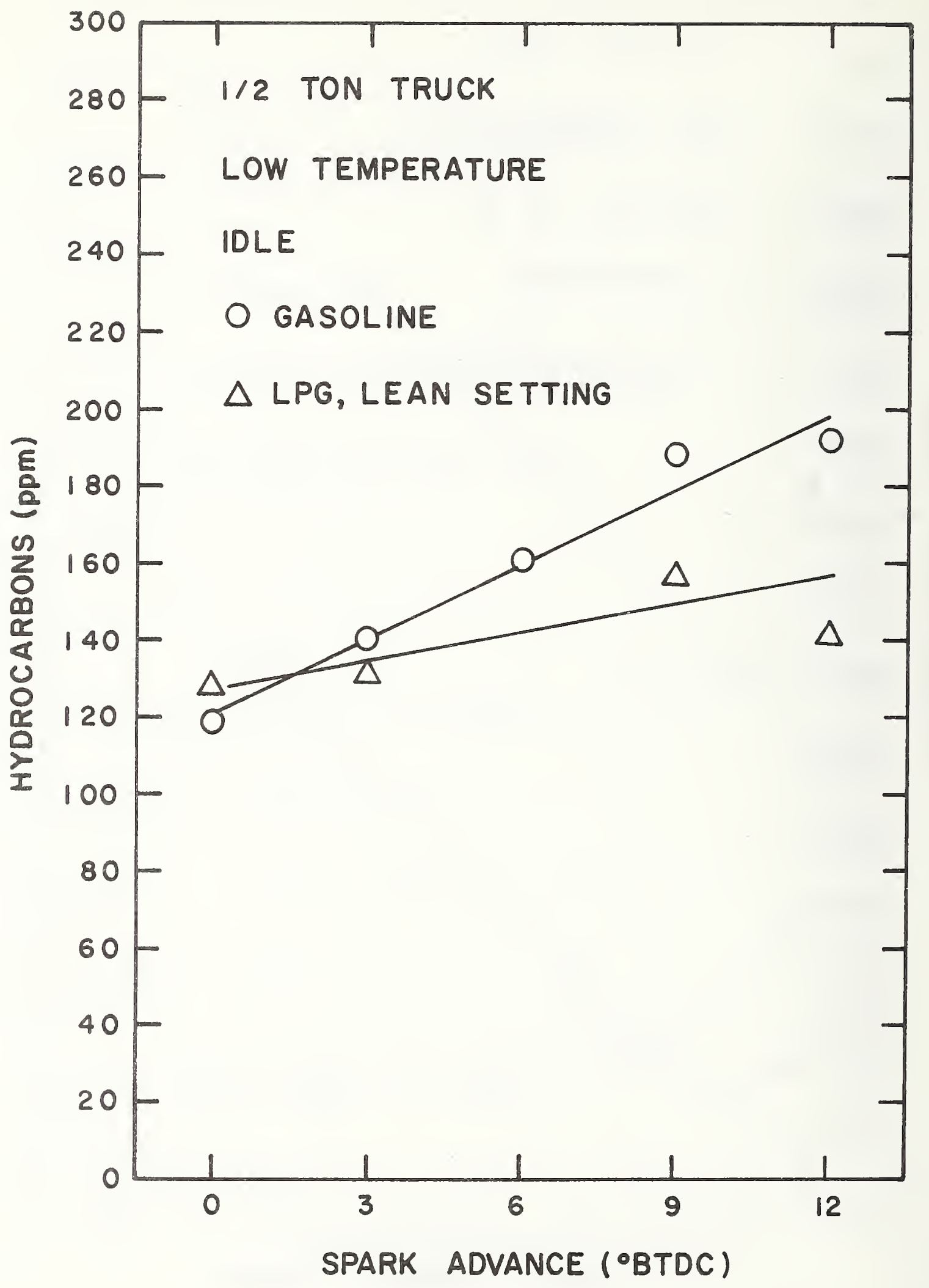

Figure 94 Hydrocarbons Versus Spark Advance for a $1 / 2$ Ton Truck Using Gasoline, and LPG 


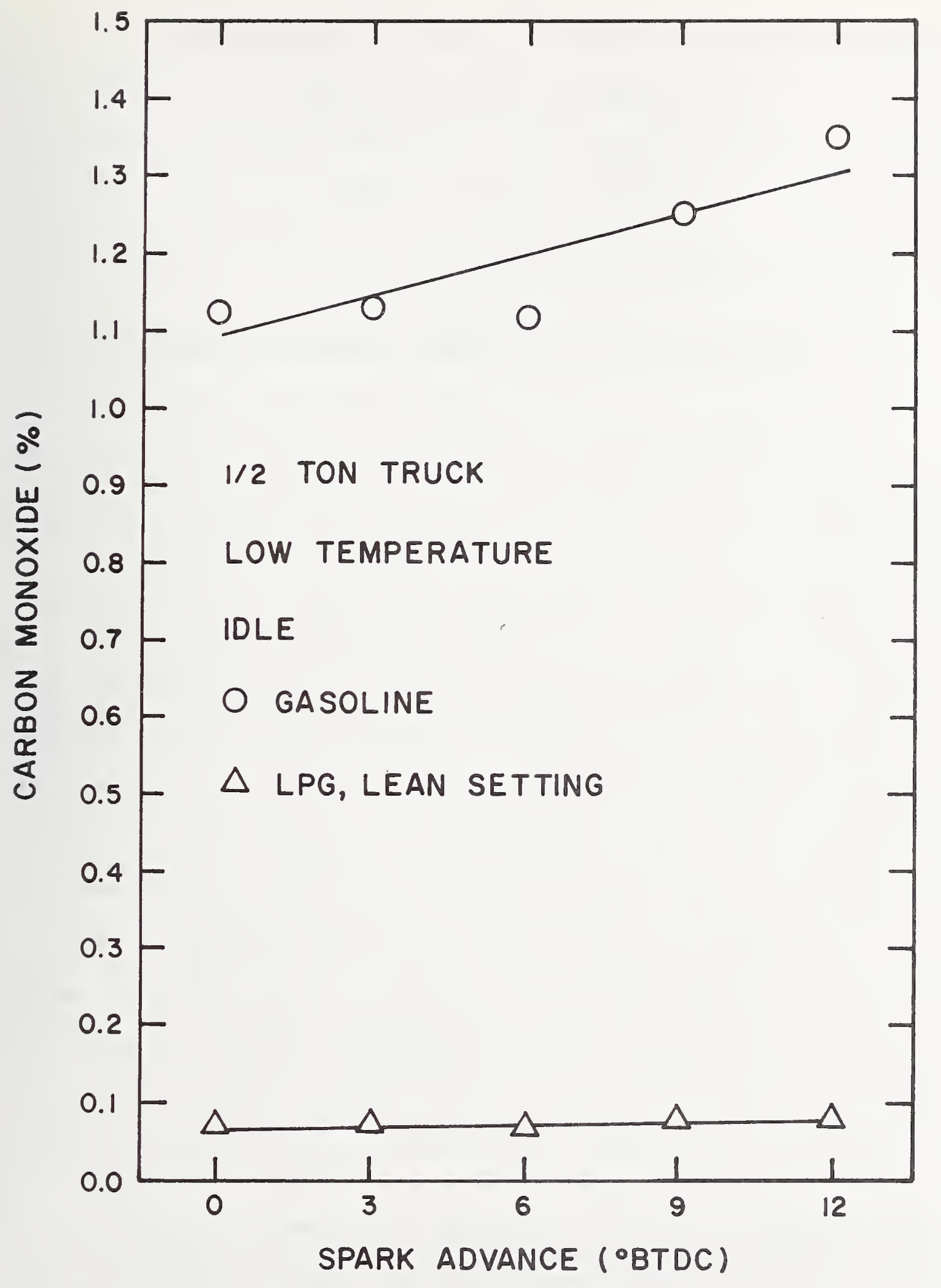

Figure 95 Carbon Monoxide Versus Spark Advance for a $1 / 2$ Ton Truck Using Gasoline, and LPG 
$0^{\circ}$ BTDC idling spark advance

$$
\text { NO } \mathrm{x}_{\mathrm{x}}(\mathrm{ppm})
$$

LPG

500

gasoline

1700
$\mathrm{HC}(\mathrm{ppm})$

$\mathrm{CO}(\%)$

170

0.13

190

1.1

\subsection{Cold Start Tests}

4.5.1 Compressed Natural Gas and Gasoline-Fueled Tests

It was decided that the most efficient procedure for determining the starting ability of the vehicle at very cold temperatures was to attempt to start it with gasoline and CNG as the fuels and with a variety of settings all during the same period of time. A series of starts were attempted at intervals such that the engine cooling fluid had returned to its temperature prior to starting the tests (and after overnight soaking at chamber temperatures close to $0^{\circ} \mathrm{F}$ ). An engine start was defined to be self sustaining operation for approximately five seconds. Any longer allowed running time would have heated the engine block so as to make the subsequent soaking period unnecessarily long. In addition to the fuels and engine settings (gas pressure, spark advance) as independent parameters, start tests were conducted with the standard ignition as we11 as a capacitor discharge (CD) ignition system (Firewell Inc.*).

* Trade names are used in this report as a means for clear identification to the Postal Service of their property. Use of a trade name neither constitutes nor implies endorsement by the National Bureau of Standards. 
In general successful starts with the standard ignition system were made in about 20 seconds with gasoline and about 20 seconds with CNG. No starts were ever completed with the capacitor discharge system supplied. A detailed analysis of the difficulty was pursued. Oscilloscope photos of the ignition coil output and spark plug voltage patterns were made for both standard and CD systems. These photos indicated that the standard system was performing normally but the CD system performance was erratic. It was conjectured that possibly the solid state components were not performing according to design specifications under the low temperature conditions. A series of start tests were then conducted with the solid state unit being maintained, first at approximately $70^{\circ} \mathrm{F}$, then $0^{\circ} \mathrm{F}$, while the rest of the engine system was kept always at $0^{\circ} \mathrm{F}$. This was acomplished by alternately blowing hot air then refrigerant on the panel-mounted solid-state unit. Each time the unit was heated, a successful start was achieved within 20 seconds. Each time the unit was cooled to $0^{\circ} \mathrm{F}$, no start was attained and there was a self-defeating type of starting sound. That is, the engine would sound as though it would fire once but then immediately the sound would die to a new low level of cranking noise. Thus it was concluded that the difficulty was in the solid state part of the system, most probably in the feedback transistor. This information was reported orally to the company representative for corrective action. At a later date, the Firewell Company's laboratory 
representative called confirming that tests conducted in their laboratories indicated that the SCR transistor would not function properly after a 24 hour soak at $0^{\circ} \mathrm{F}$ and that future units would be corrected.

4.5.2 Propane and Gasoline-Fueled Tests

These tests were particularly significant in that the corrected capacitor discharge ignition system (CDI) was available for testing. After exposing the $1 / 2$ ton truck to ambient temperatures of $0^{\circ} \mathrm{F}$ for 24 hours, it was found that the engine could be started within 10 seconds using LPG or gasoline as the fuel and with or without the CDI system. Since the vehicle could be started so easily, it was difficult to tell whether the CDI system made any difference. The important finding though was that the previous malfunctioning had evidently been corrected. 
5. Results and Discussion - 1 Ton Truck

Figures 96 through 130 show data that was taken on the 1 ton truck. The primary independent variables during the tests were again idling spark advance and air-fuel ratio at the respective running conditions. The way in which the data was taken and is shown here is similar in many ways to that which was done on the $1 / 2$ ton truck; however, differences did result and will be noted.

\subsection{Gasoline-Fueled Tests}

Figures 96 through 105 give the results for the vehicle run on gasoline fuel. As with the first vehicle, the independent variable was spark advance only, since air-fuel ratio cannot be varied easily in modern carburetors.

Figures 96 and 97 show the nitrogen oxide emissions as a function of spark advance for idle, $20 \mathrm{mph}$ and $4 \mathrm{hp}$, and 50 mph and 30 hp running conditions, at three ambient temperature levels. In general, there was a slight increase in $N_{x}$ with spark advance, a more significant increase with ambient temperature and, as seen more clearly in the replot on Figure 98, a very significant increase with running speed and horsepower. One data curve, namely the $50 \mathrm{mph}-30 \mathrm{hp}$ at $17^{\circ} \mathrm{F}$ curve of Figure 96 , is of questionable reliability since it did not follow the general trend with temperature noted above.

The hydrocarbon and carbon monoxide data for these same tests are shown in Figures 99 through 101 and 102 through 105 


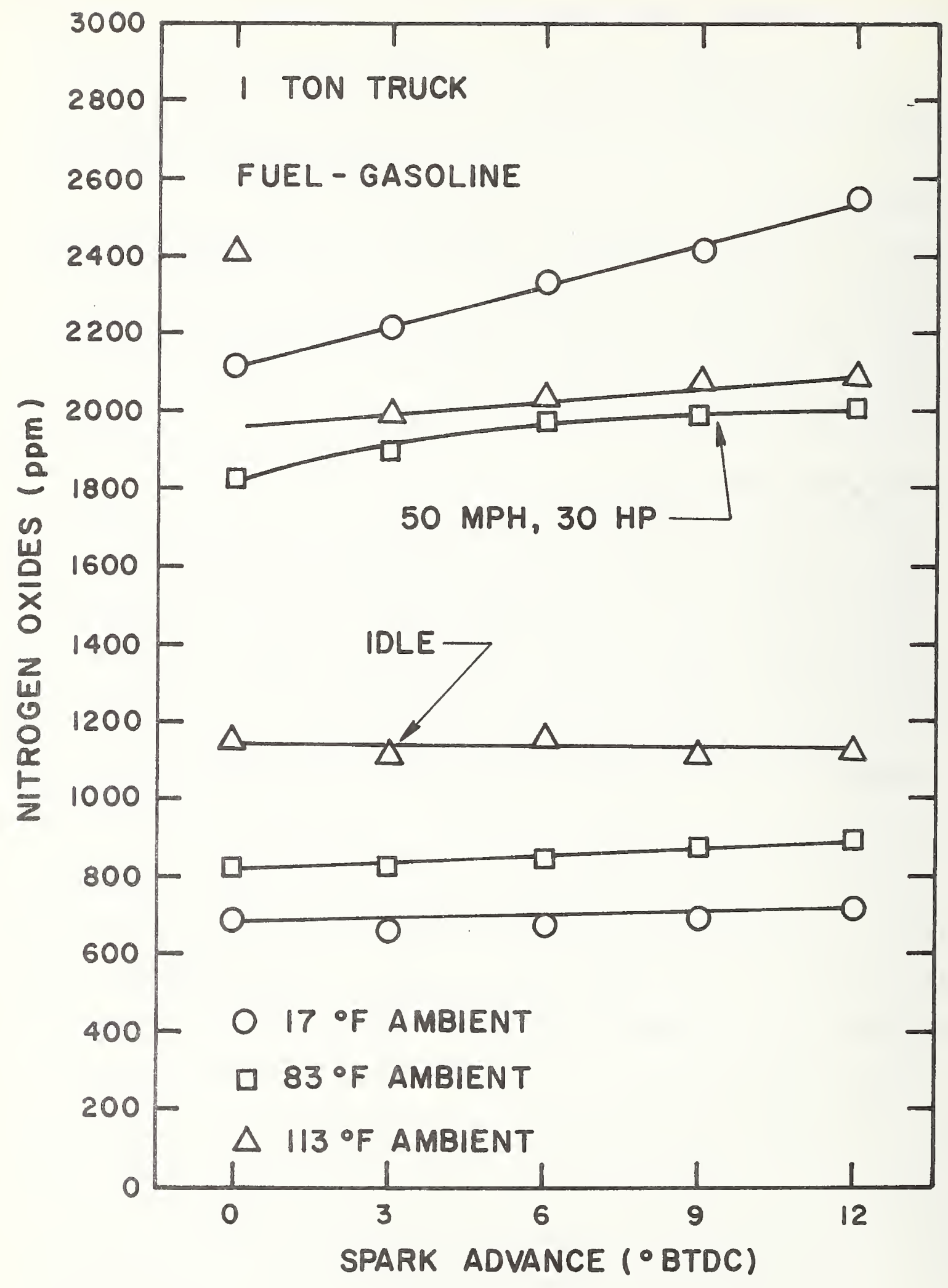

Figure 96 Nitrógen Oxides Versus Spark Advance for a 1 Ton Truck Using Gasoline 


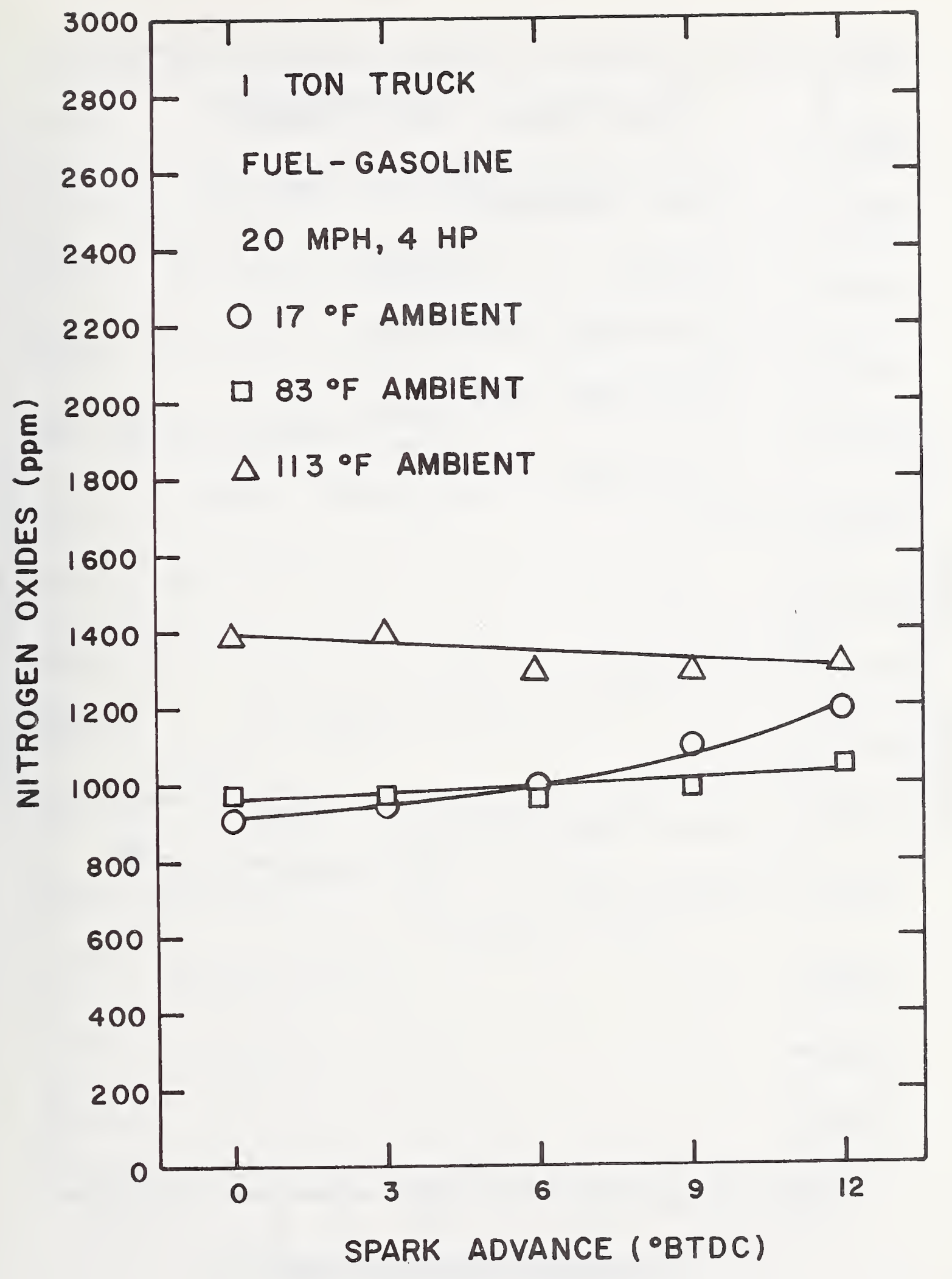

Figure 97 Nitrogen Oxides Versus Spark Advance for a 1 Ton Truck Using Gasoline 


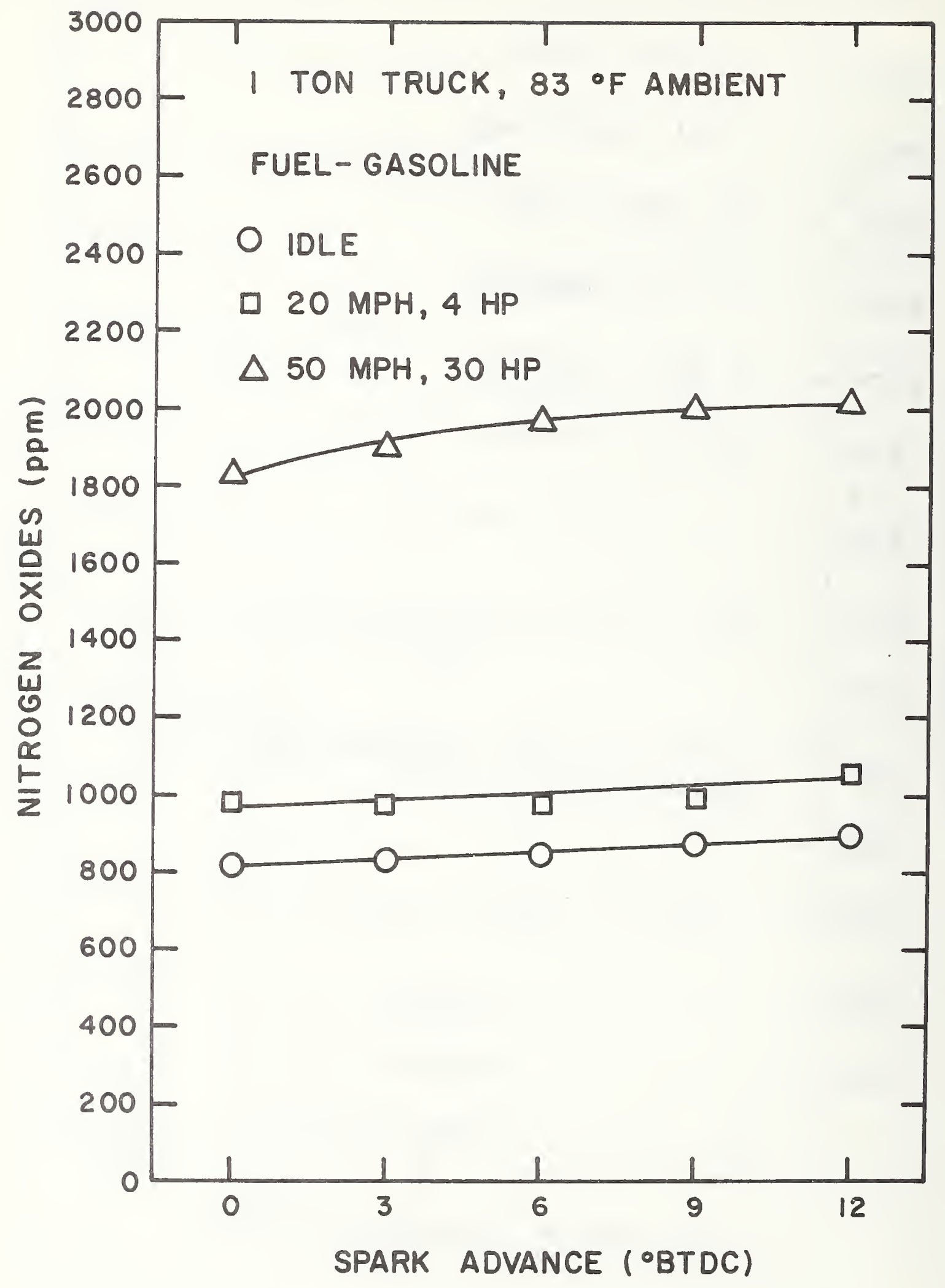

Figure 98 Nitrogen Oxides Versus Spark Advance for a 1 Ton Truck Using Gasoline 


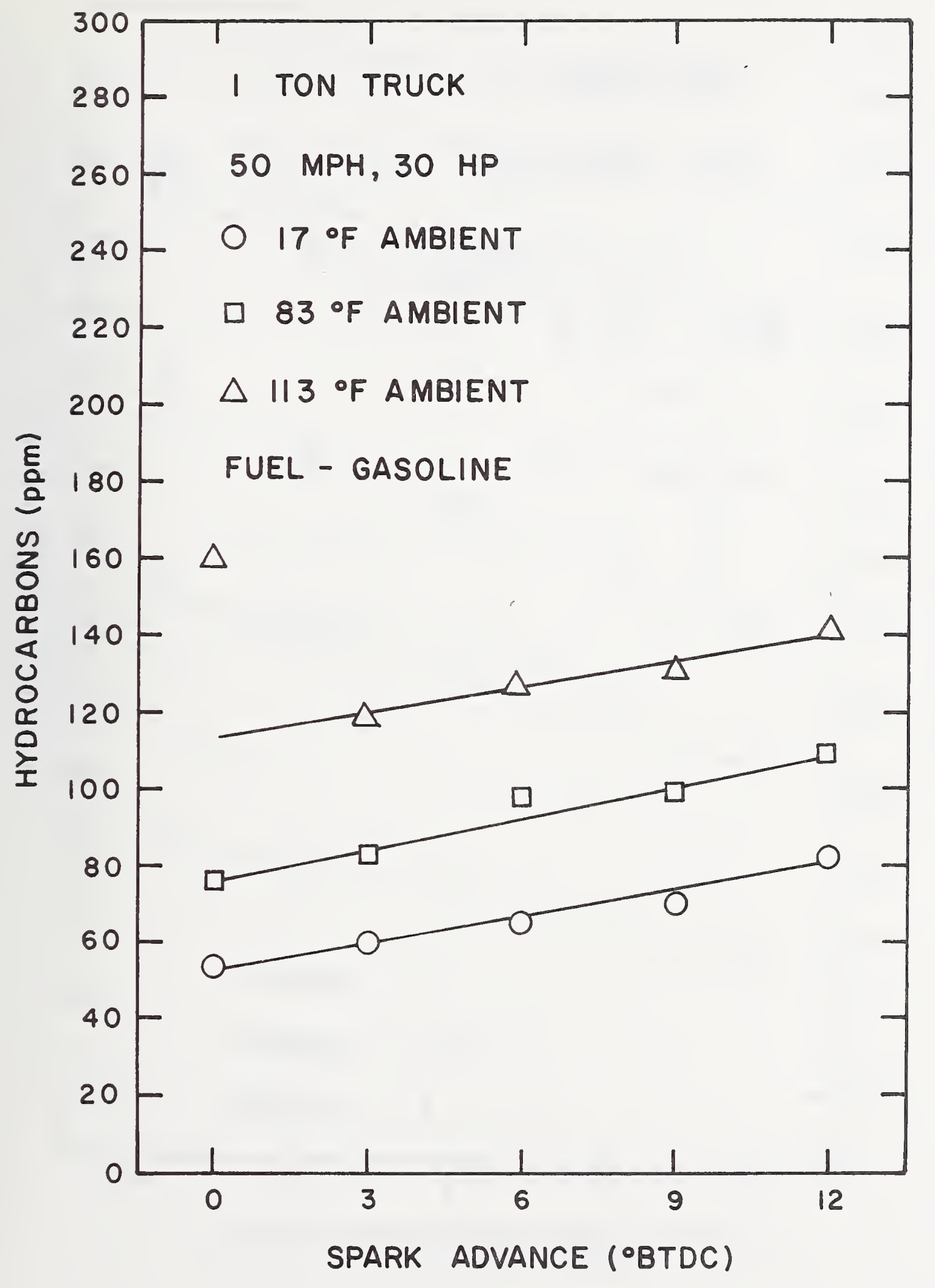

Figure 99 Hydrocarbons Versus Spark Advance for a 1 Ton Truck Using Gasoline 


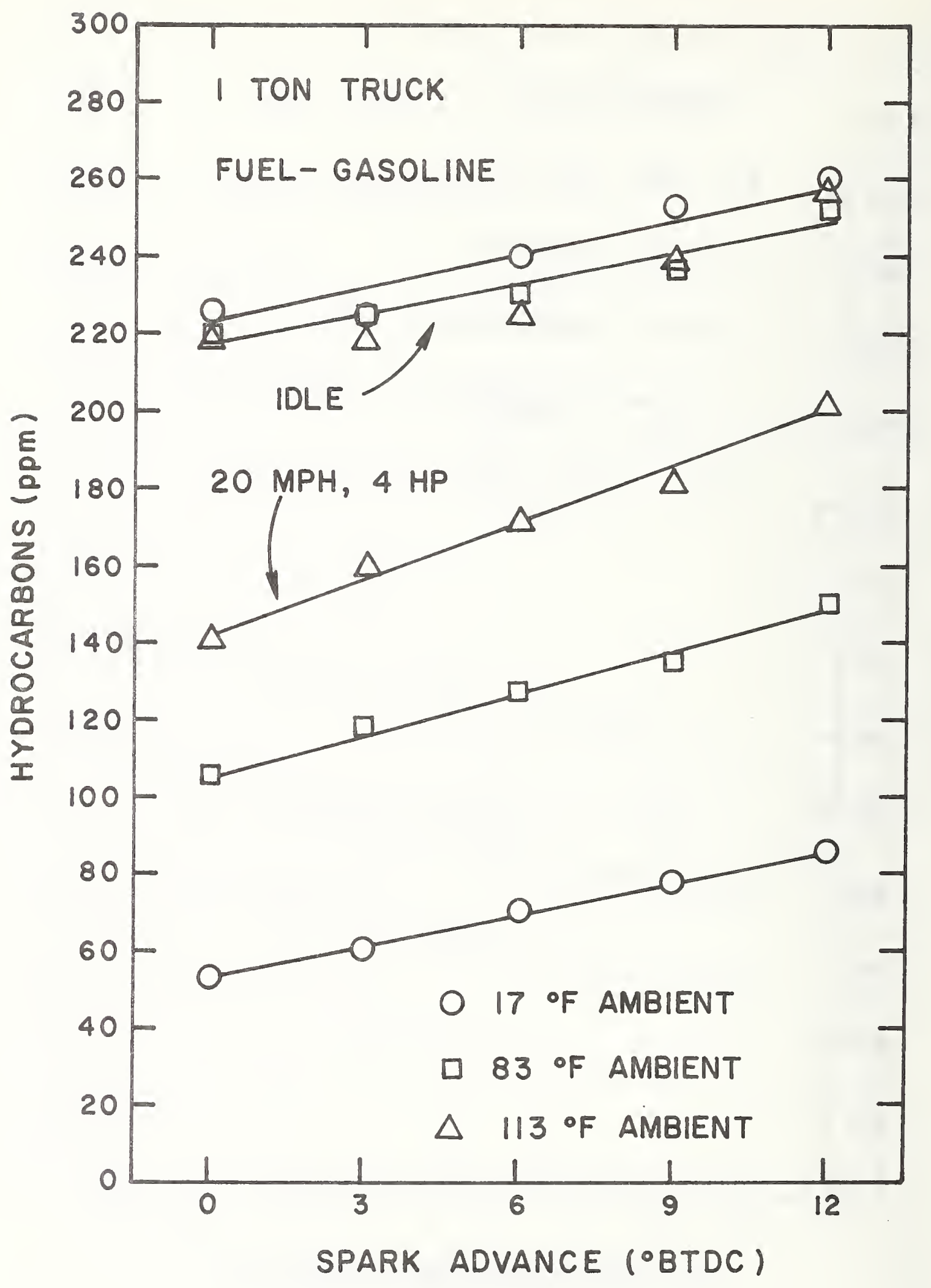

Figure 100 Hydrocarbons Versus Spark Advance for a 1 Ton Truck Using Gasoline 


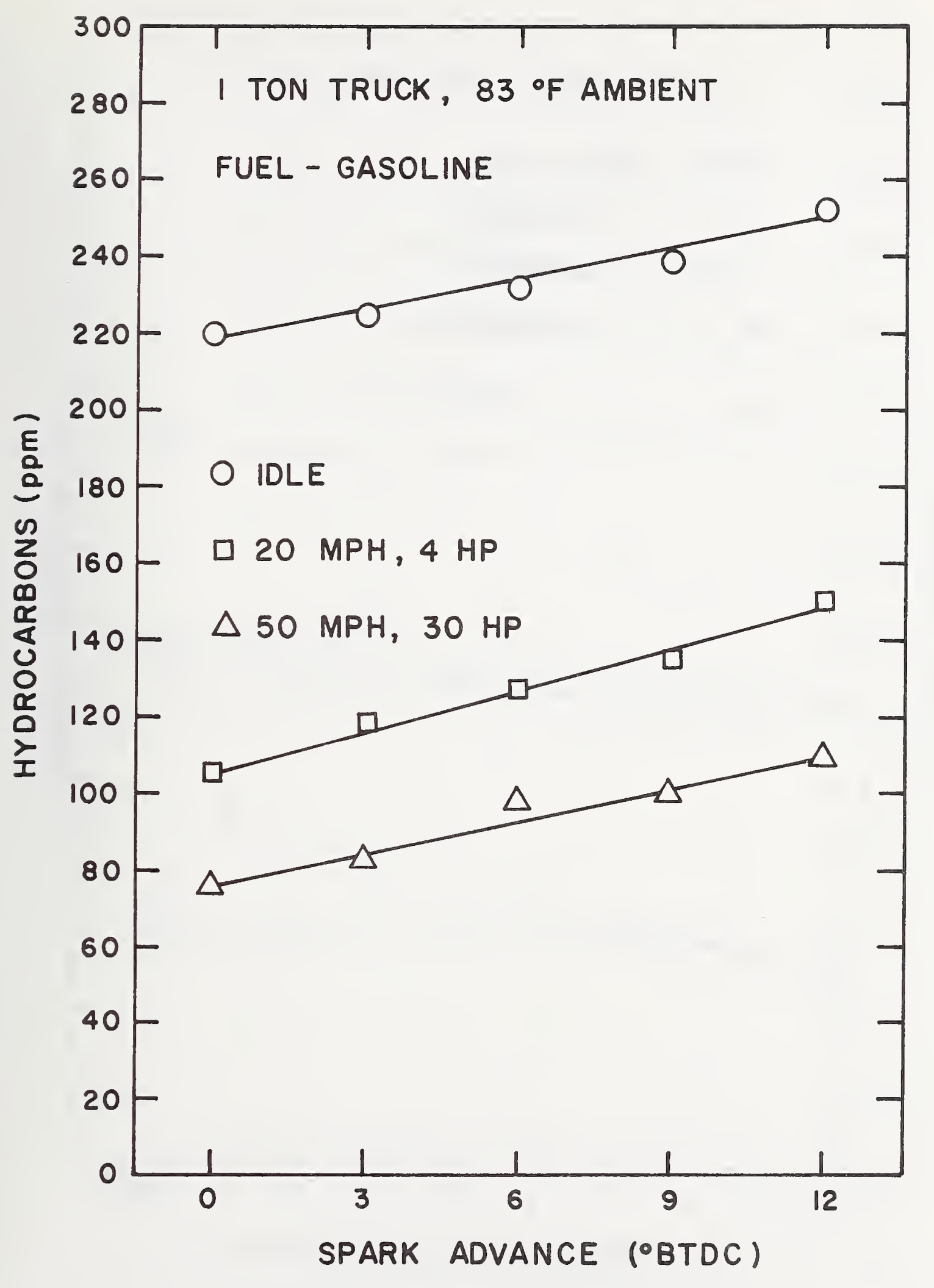

Figure 101 Hydrocarbons Versus Spark Advance for a 1 Ton Truck Using Gasoline 


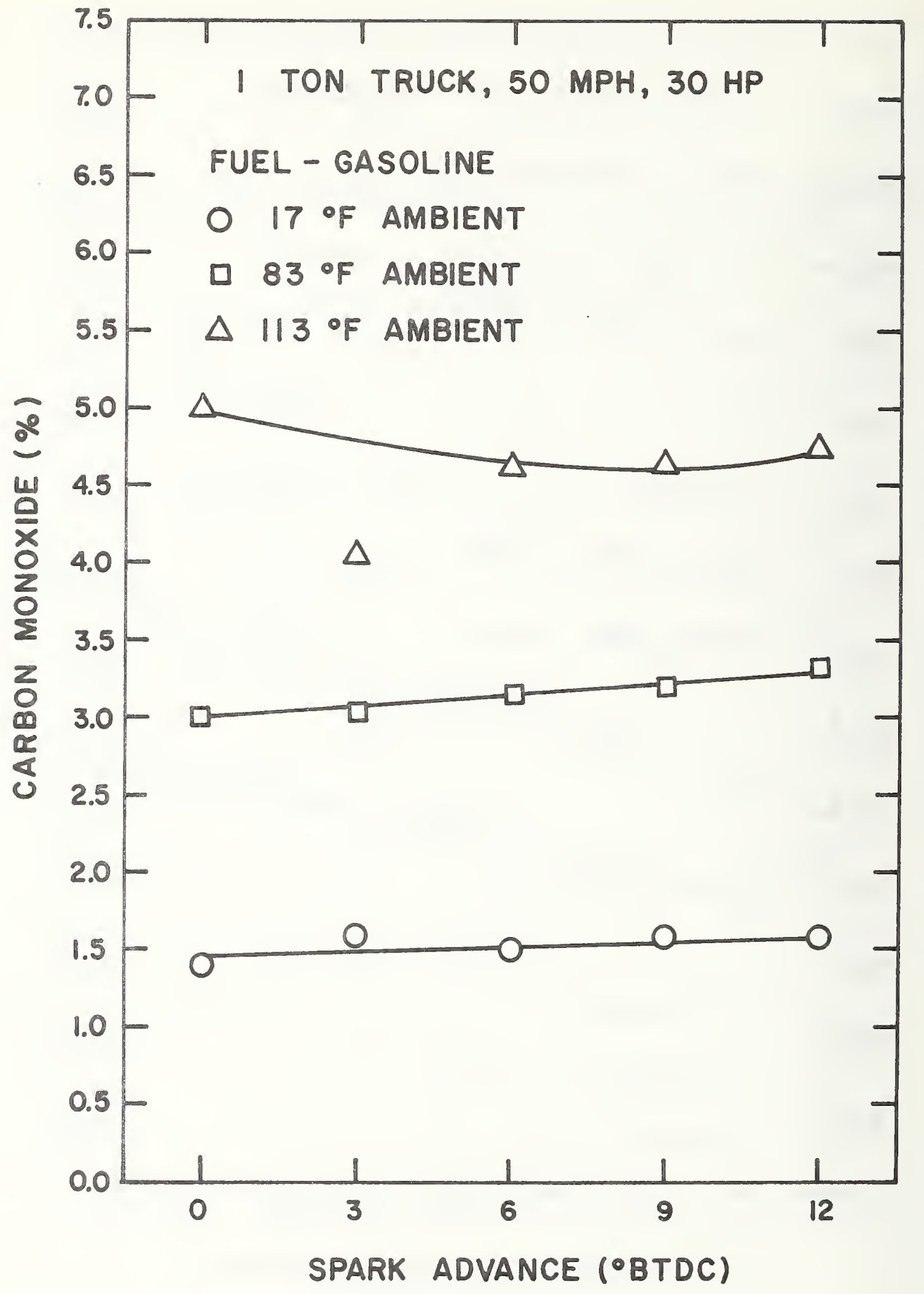

Figure 102 Carbon Monoxide Versus Spark Advance for a 1 Ton Truck Using Gasoline 


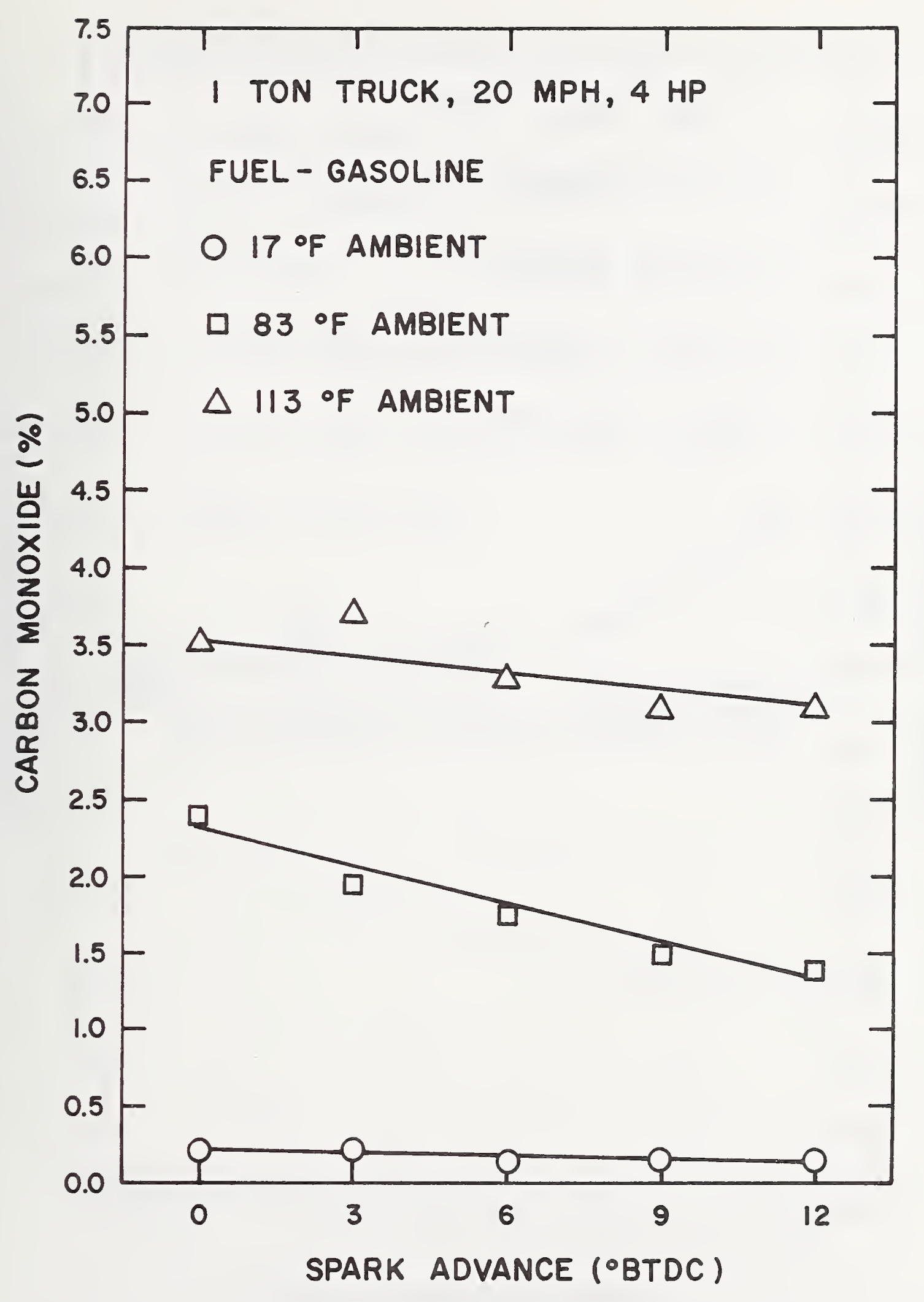

Figure 103 Carbon Monoxide Versus Spark Advance for a 1 Ton Truck Using Gasoline 


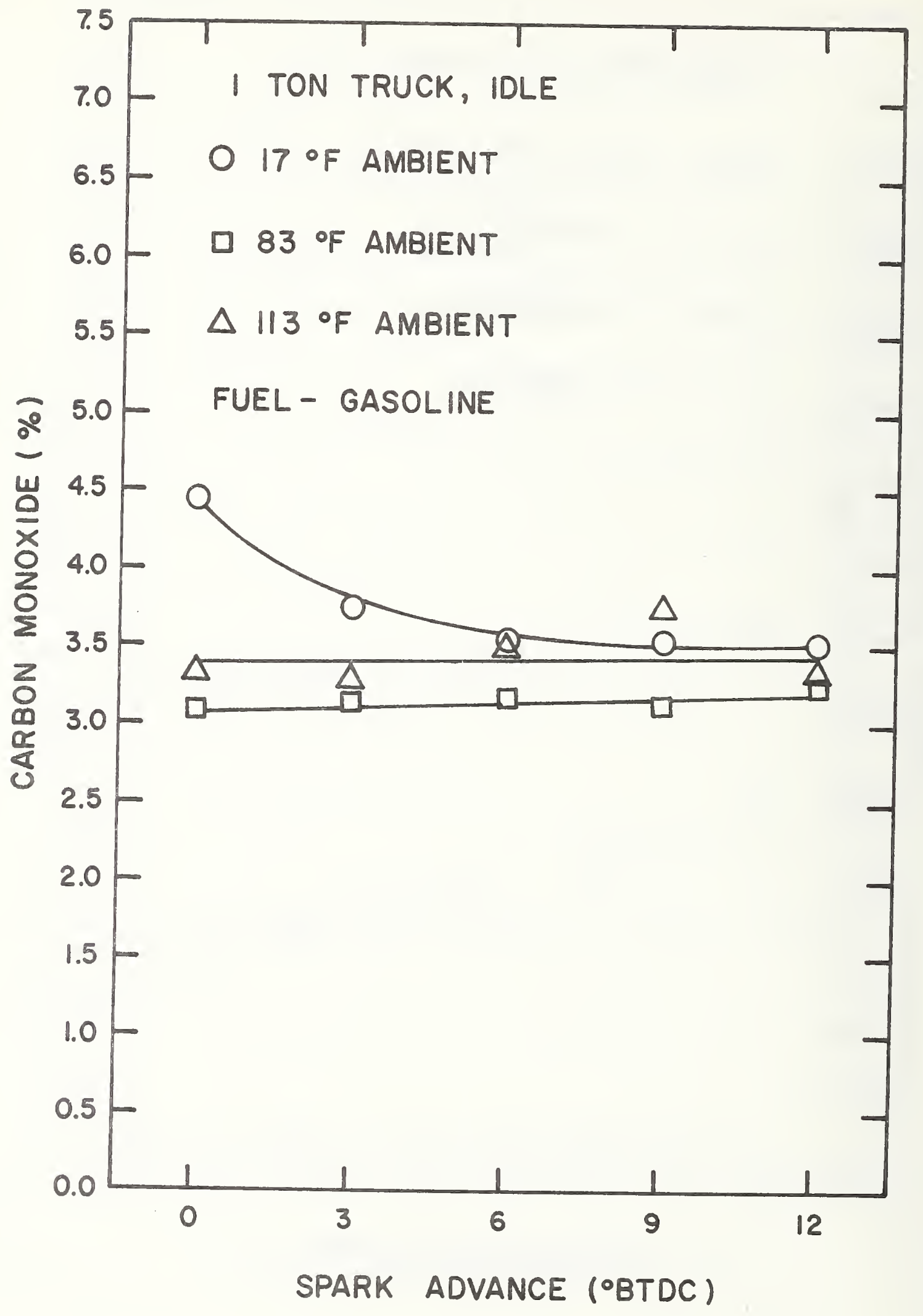

Figure 104 Carbon Monoxide Versus Spark Advance for a 1 Ton Truck Using Gasoline 


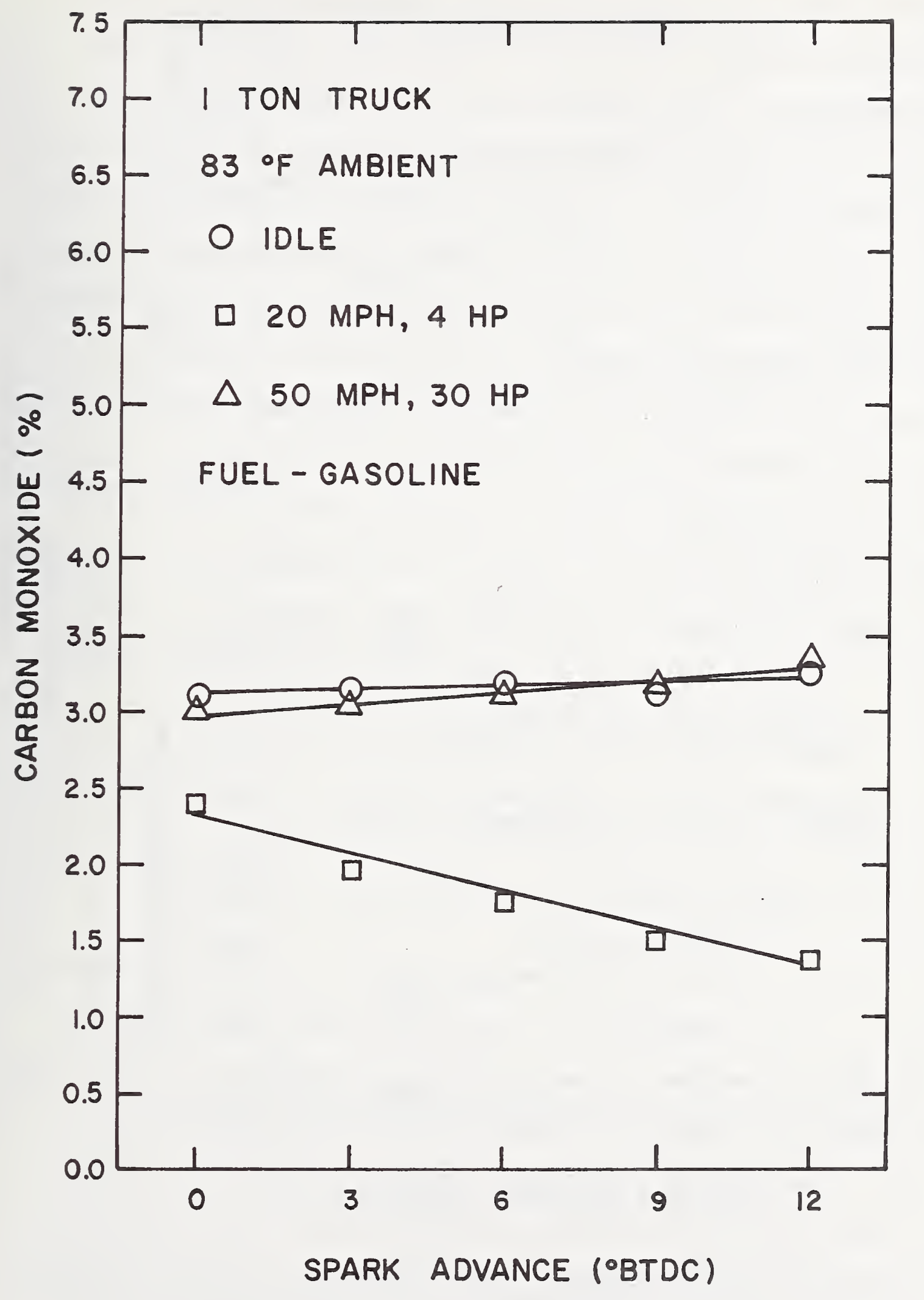

Figure 105 Carbon Monoxide Versus Spark Advance for a 1 Ton Truck Using Gasoline 
respectively. For both these pollutants at either $20 \mathrm{mph}$ or $50 \mathrm{mph}$, the higher the ambient temperature, the larger were the emissions. This occurred since the throttle was opened wider to maintain the same horsepower (as the temperature was increased) and thus the air-fuel ratio was slightly decreased. (The HC and CO emissions are extremely sensitive to $\mathrm{A} / \mathrm{F}$ ratio on the rich side of the stoichiometric condition where normal gasoline carburetors operate.) The idle data (Figure 100 and Figure 104) show little dependence on ambient temperature since the prime influence is the independent fuel adjustment screw for smooth running. As with the first vehicle, the spark advance had only a modest effect on hydrocarbons and in most cases an even less effect on the carbon monoxide. As can be seen in Figures 101 and 105 , these two pollutants went down as the running speed was increased.

\subsection{Compressed Natural Gas-Fueled Tests}

5.2.1 Spark Advance as the Independent Variable

Figures 106 and 108 show the results of two sets of tests run at $5^{\circ} \mathrm{F}$ and $109^{\circ} \mathrm{F}$ ambient conditions for $20 \mathrm{mph}-4 \mathrm{hp}$ and idle conditions respectively. The usual $50 \mathrm{mph}-30$ hp test was not performed because the engine exhaust manifold began to "glow" from the heat under that load. The glowing manifold was measured to be in excess of $1350^{\circ} \mathrm{F}$ and it was considered too dangerous to the exhaust valve stems to continue testing at that condition. The comparison of the data at different 


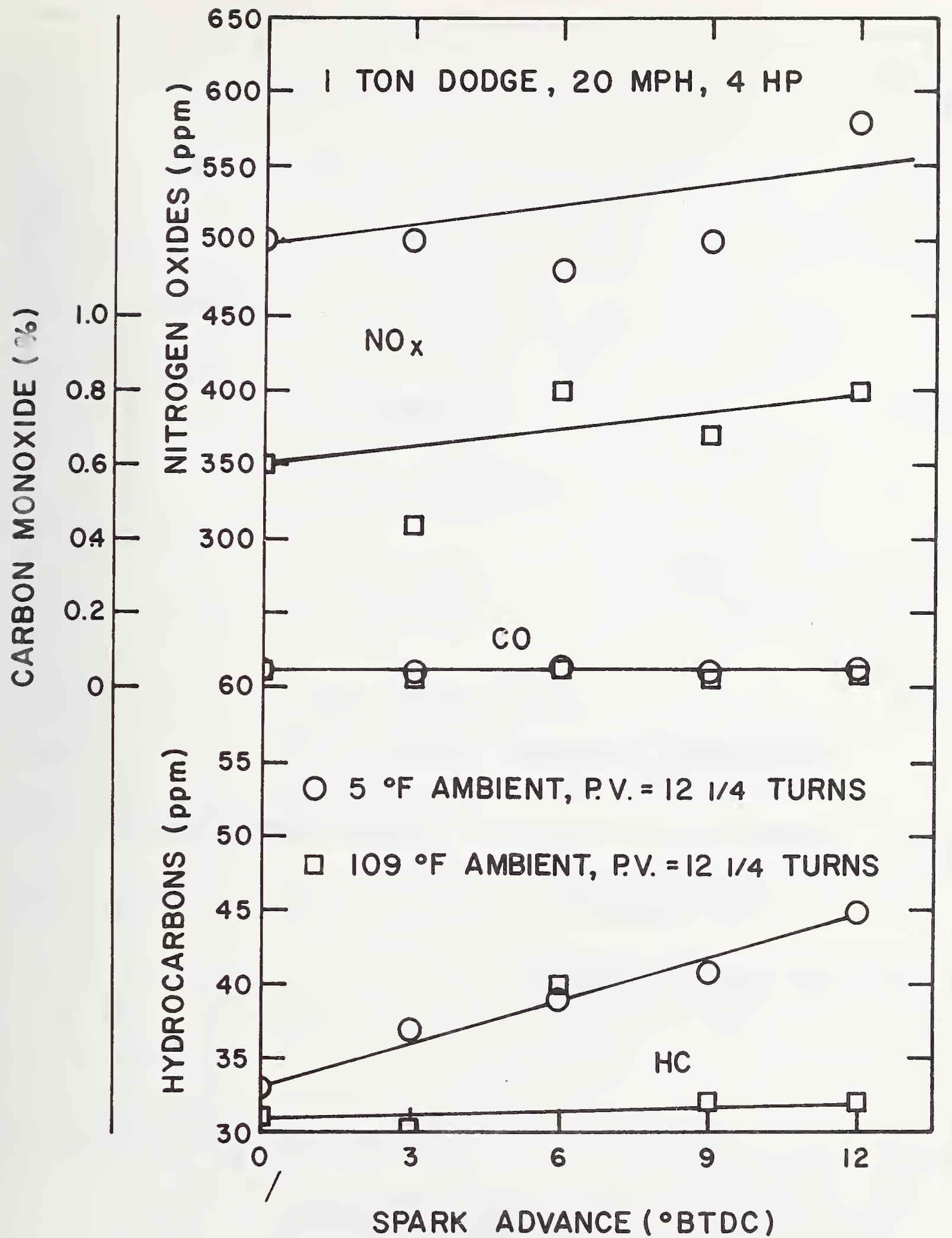

Figure 106 Pollutants Versus Spark Advance for a 1 Ton Truck Using CNG 


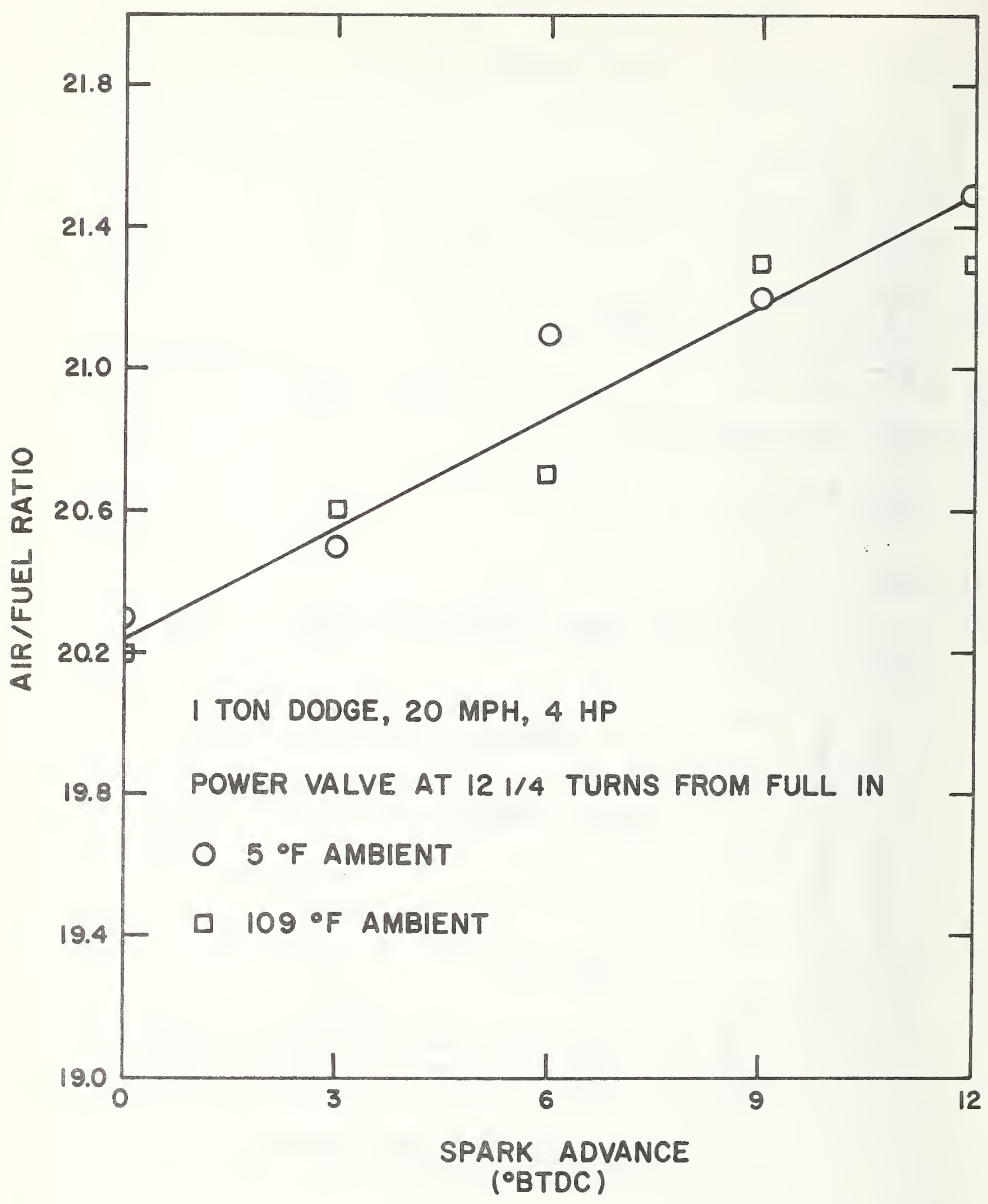

Figure 107 Air-Fuel Ratio Versus Spark Advance for a 1 Ton Truck Using CNG 


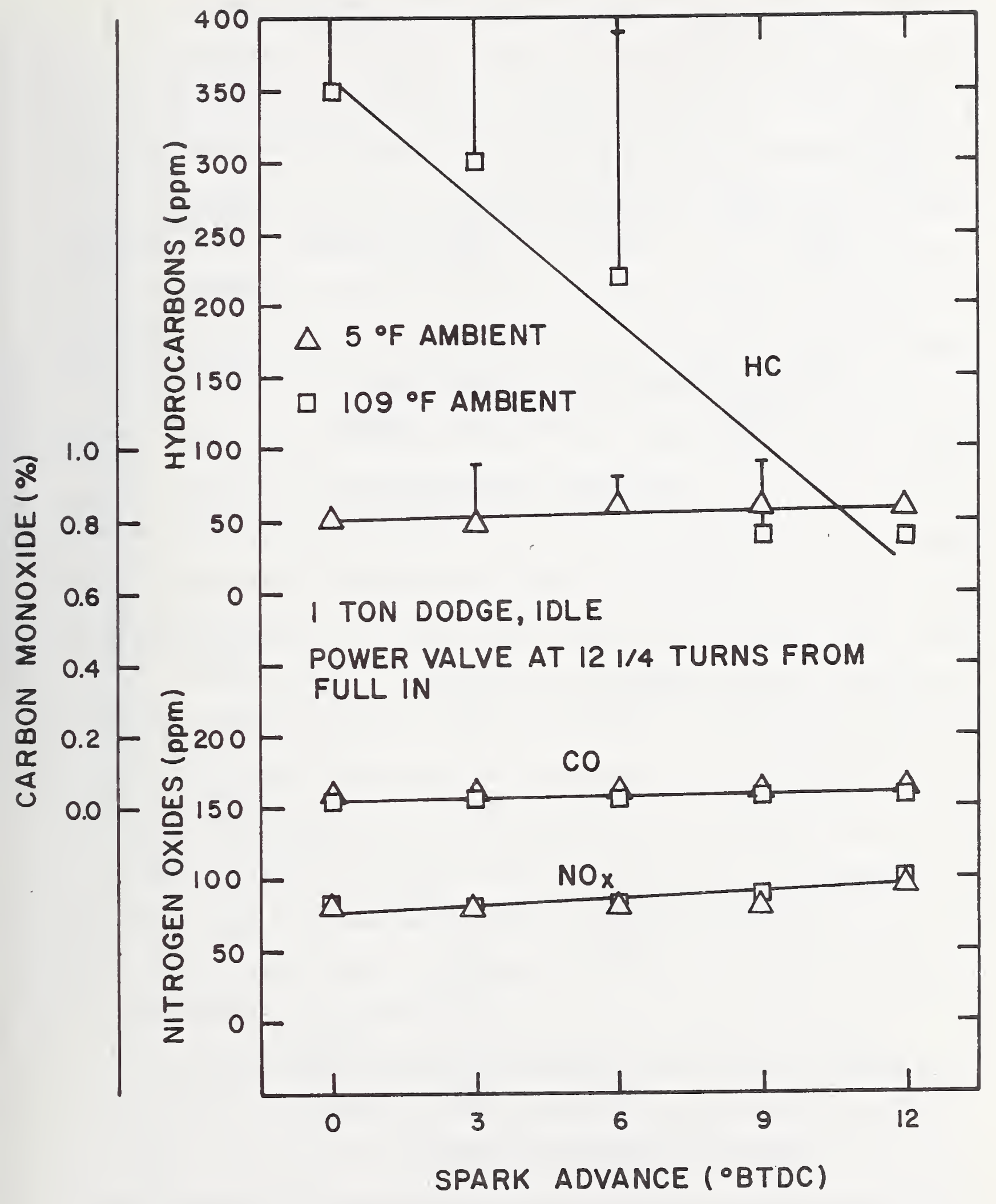

Figure 108 Pollutants Versus Spark Advance for a 1 Ton Truck Using CNG 
ambient temperatures indicates that there was no change in carbon monoxide emissions and little change in hydrocarbons as the temperature was increased. The hydrocarbon curves do diverge but the data scatter and fluctuations of either test prevent making any conclusive deductions about temperature. Such scatter is often encountered because of the HC sensitivity to engine maintenance. The $\mathrm{NO}_{\mathrm{x}}$ did not change under idle conditions but did decrease somewhat with increasing temperature at $20 \mathrm{mph}$ and $4 \mathrm{hp}$. The tests at $109^{\circ} \mathrm{F}$ were repeated several times for the same power valve setting and the $\mathrm{NO}_{x}$ levels varied great1y. However, the air-fuel ratio was determined for each test and it was found to change each time in spite of the same power valve setting and the same gas regulator pressure. Figure 107 shows the air-fuel ratio that occurred in the one $109^{\circ} \mathrm{F}$ test that was chosen for plotting. It was chosen because the air-fuel ratio was similar to the one $5^{\circ} \mathrm{F}$ test (as seen in Figure 107). Since the comparison was made with the same spark advance and air-fuel ratio, the difference in $\mathrm{No}_{\mathbf{x}}$ may be due to the increased mixture density at lower temperatures. The more significant result, however, was the variation in air-fuel ratio that occurred with the same power valve setting. Figures 109 and 110 show a comparison of the emissions when operating with the capacitor discharge ignition system and the standard ignition system under $5^{\circ} \mathrm{F}$ ambient conditions. As can be seen, no significant differences were noted. Start tests with the CDI system on this vehicle are discussed later in this report. 


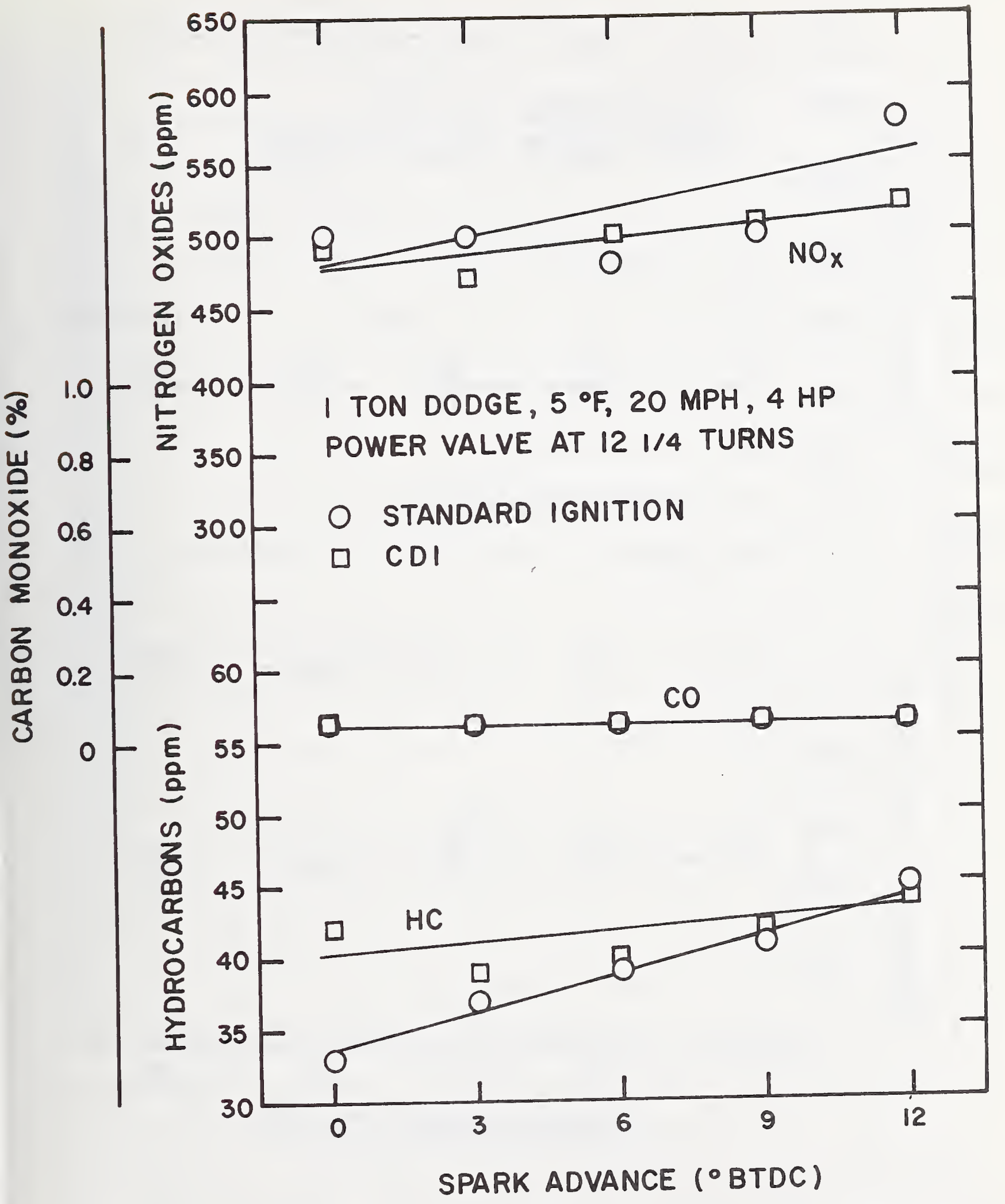

Figure 109 Pollutants Versus Spark Advance for a 1 Ton Truck Using CNG 


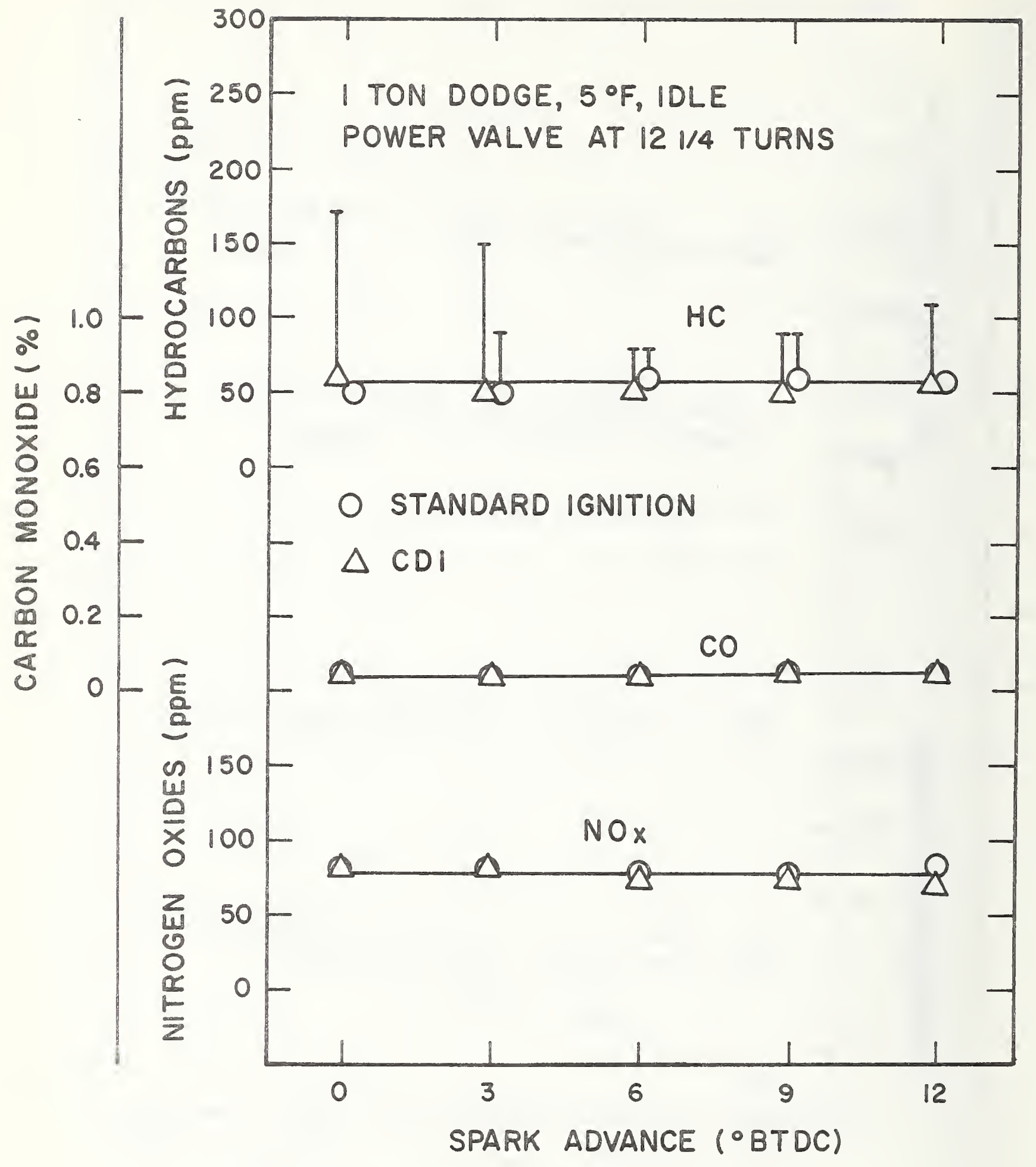

Figure 110 Pollutants Versus Spark Advance for a 1 Ton Truck Using CNG 
Figures 111 through 122 are the results of a unique series of tests performed in an attempt to find the optimum settings for spark advance and air-fuel ratio. The criteria imposed was that at each speed ( $50 \mathrm{mph}, 20 \mathrm{mph})$ the mixture would be leaned so that the respective power ( $30 \mathrm{hp}, 4 \mathrm{hp})$ designated as necessary by the Postal Service requirements would be the maximum power available. This presumably would yield the minimum pollution while still offering a marginal vehicle performance. The tests were begun at $0^{\circ}$ spark advance with the throttle wide open. At $50 \mathrm{mph}$ the power valve was turned until the fuel rate was sufficient to produce only 30 horsepower at the wheels. Then, as the spark was advanced and more power became available the power valve was turned in to limit the vehicle to $30 \mathrm{hp}$. These same settings were noted and then duplicated for the $20 \mathrm{mph}$ and idle tests at each spark setting. On each of the graphs, the data for the respective gasoline test was replotted from previous graphs for comparison. Figures 111,112 , and 113 are the results for $8^{\circ} \mathrm{F}$ ambient, Figures 115,116 , and 117 are for $82^{\circ} \mathrm{F}$ ambient, and Figures 119,120 , and 121 are for $110^{\circ} \mathrm{F}$ ambient. In general, the tendency for the $\mathrm{NO}_{x}$ to increase with increasing spark advance was offset by the leaning of the mixture. On the other hand, hydrocarbons tended to increase probably due to the slowing down of the flame speed by the leaning out procedure. As expected the carbon monoxide was so minimal that no change was detected. One additional limitation was that by the time $12^{\circ}$ 


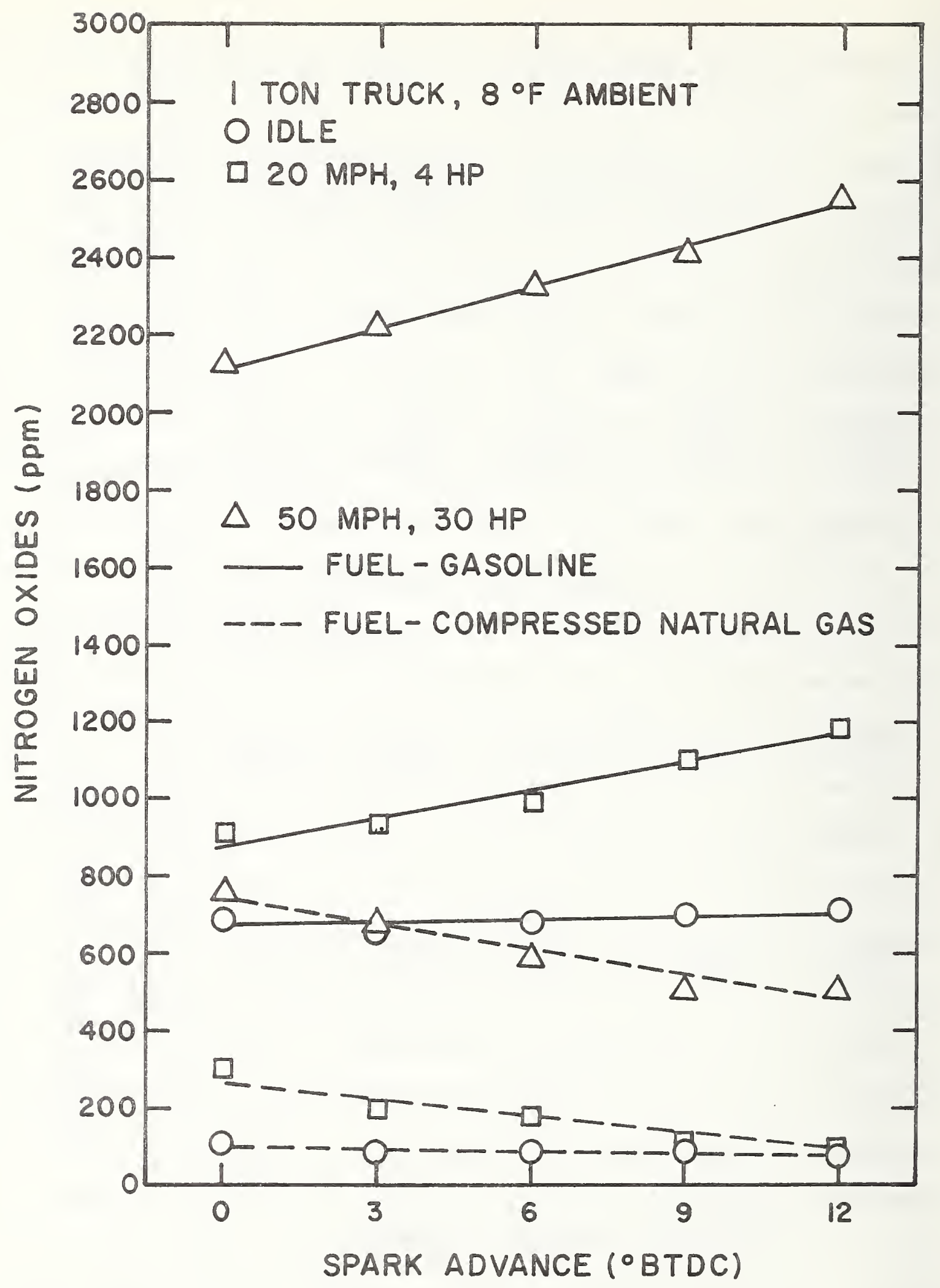

Figure 111 Nitrogen Oxides Versus Spark Advance for a 1 Ton Truck Using CNG 


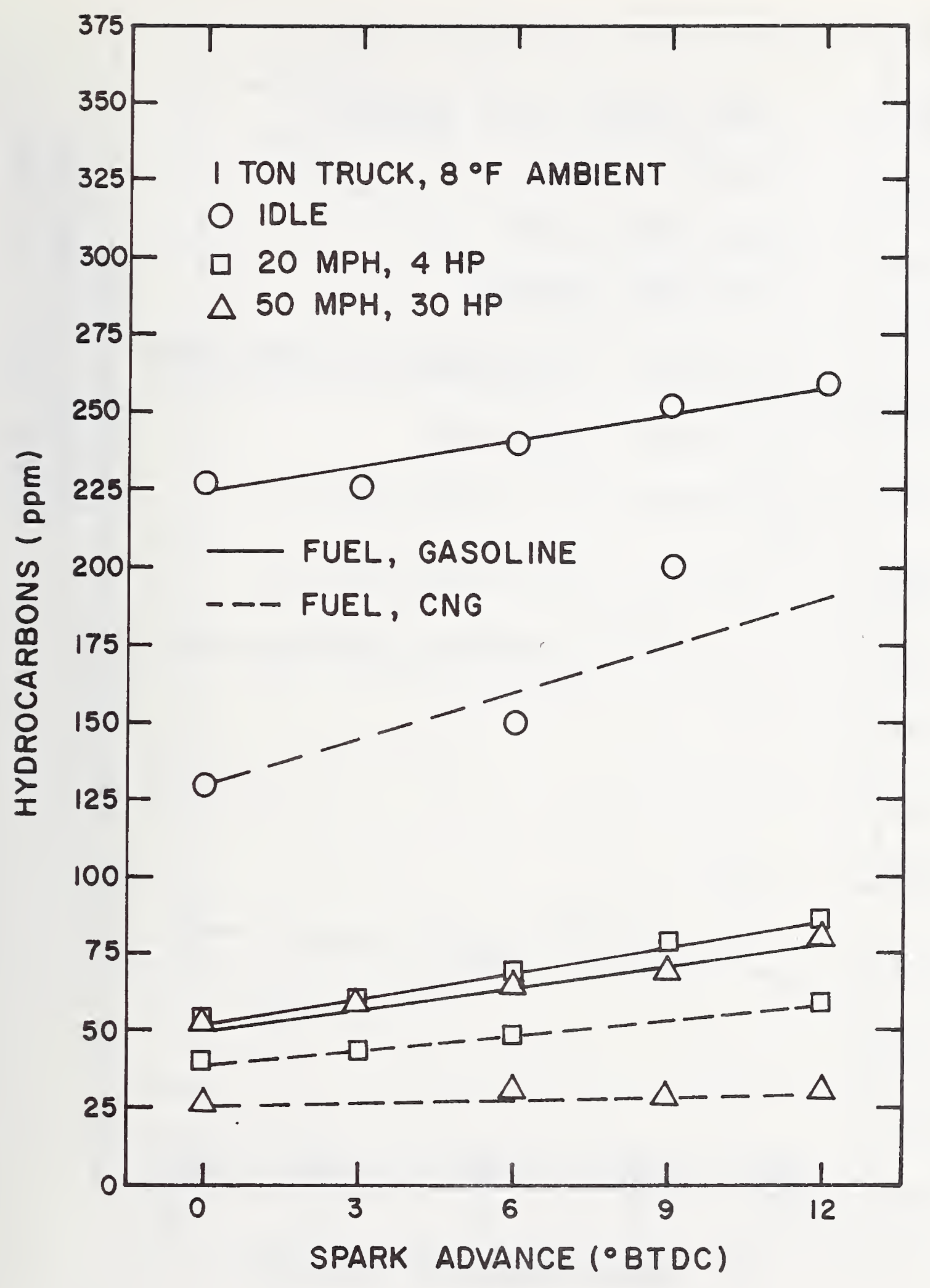

Figure 112 Hydrocarbons Versus Spark Advance for a 1 Ton Truck Using CNG 


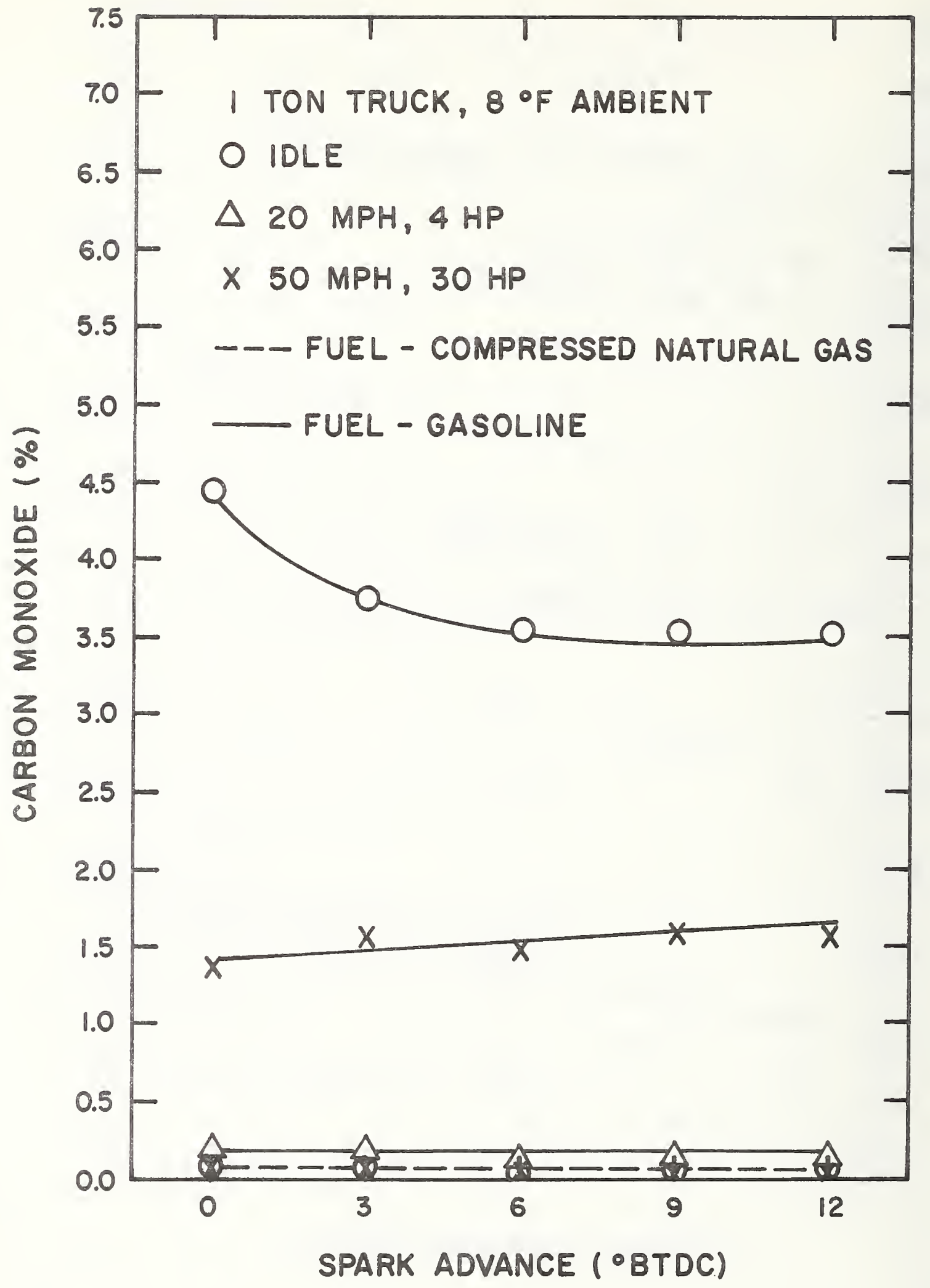

Figure 113 Carbon Monoxide Versus Spark Advance for a 1 Ton Truck Using CNG 


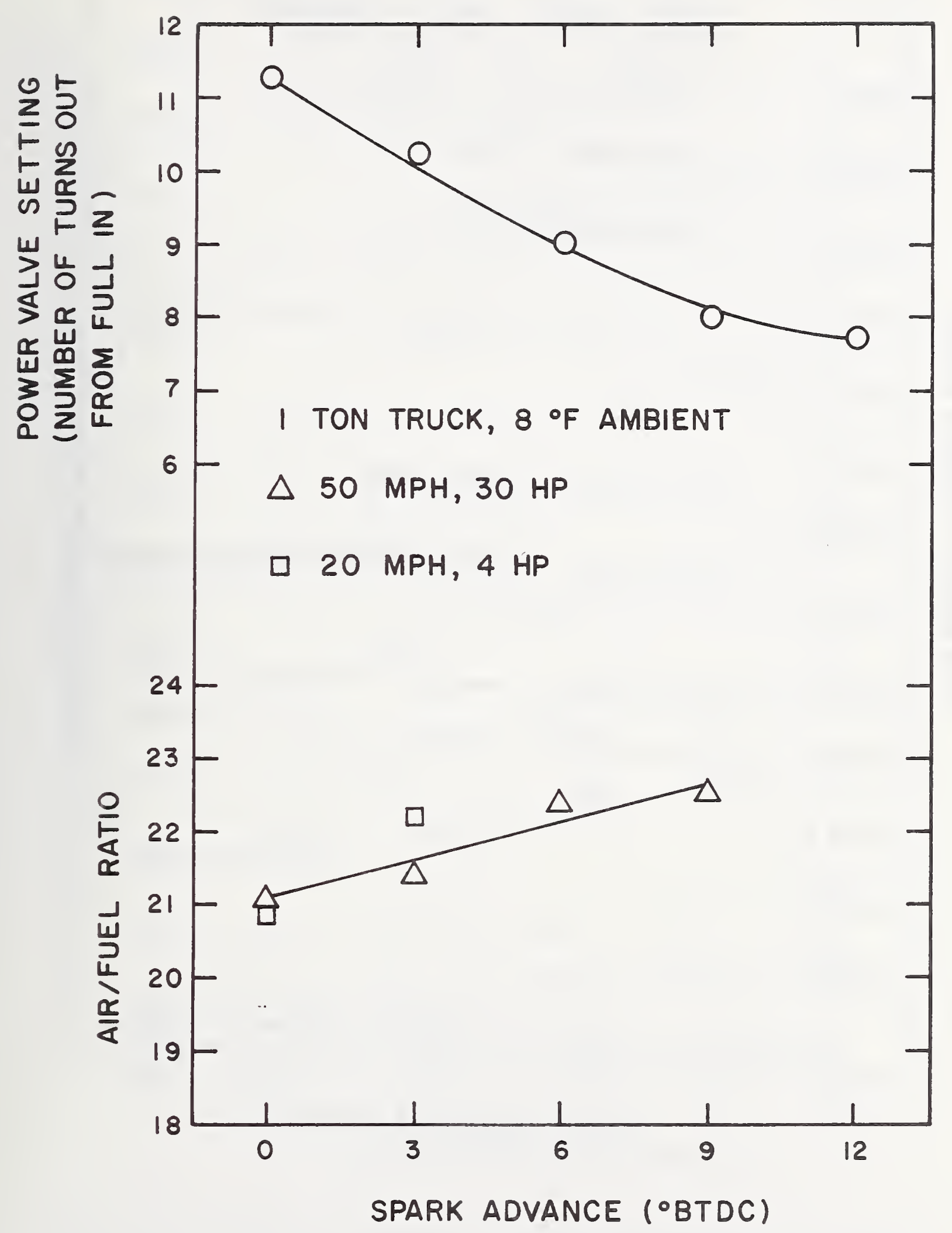

Figure 114 Air-Fue 1 Ratio and Power Valve Setting Versus Spark Advance for a 1 Ton Truck Using CNG 


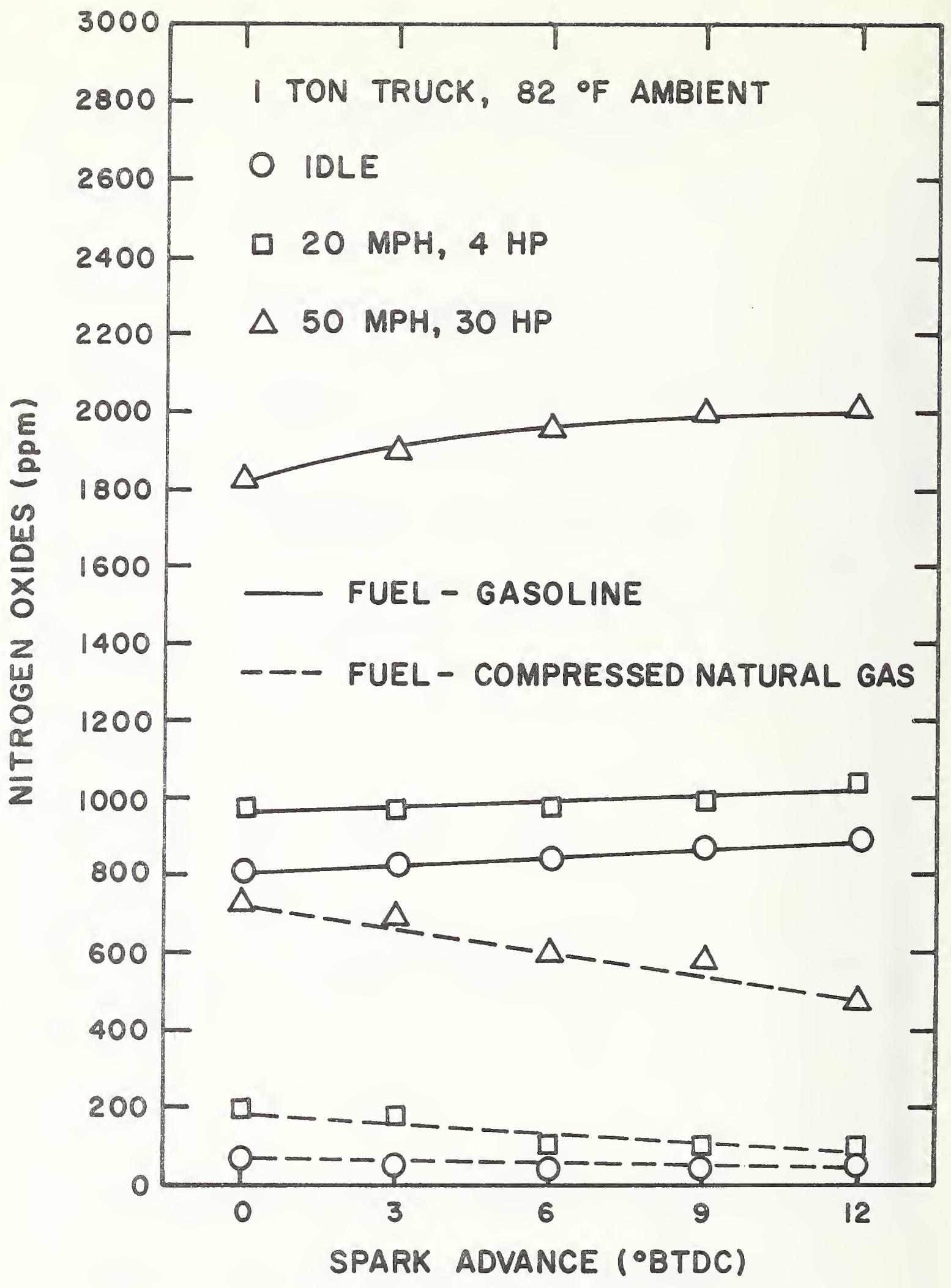

Figure 115 Nitrogen Oxides Versus Spark Advance for a 1 Ton Truck Using CNG 


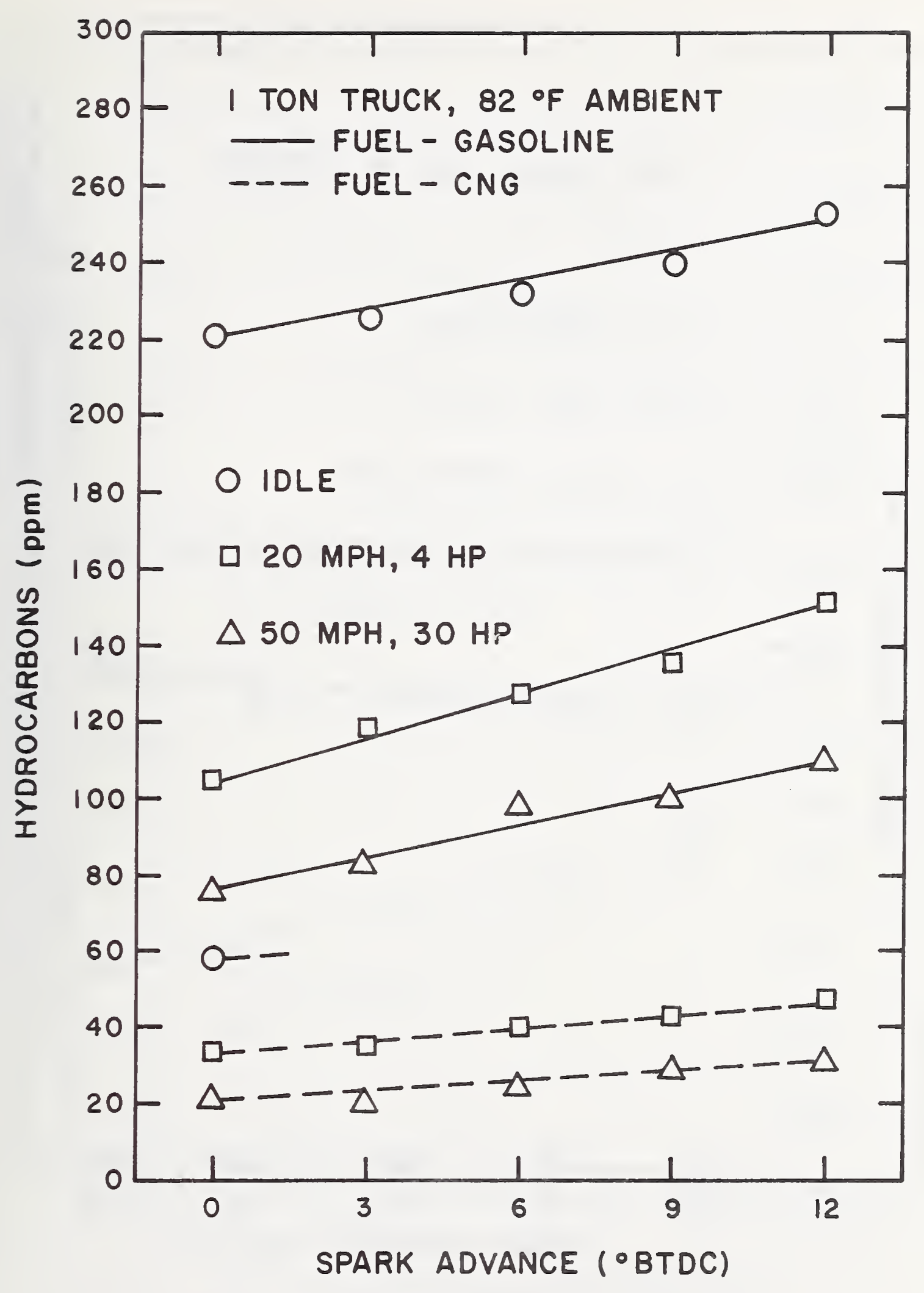

Figure 116 Hydrocarbons Versus Spark Advance for a 1 Ton Truck Using CNG 


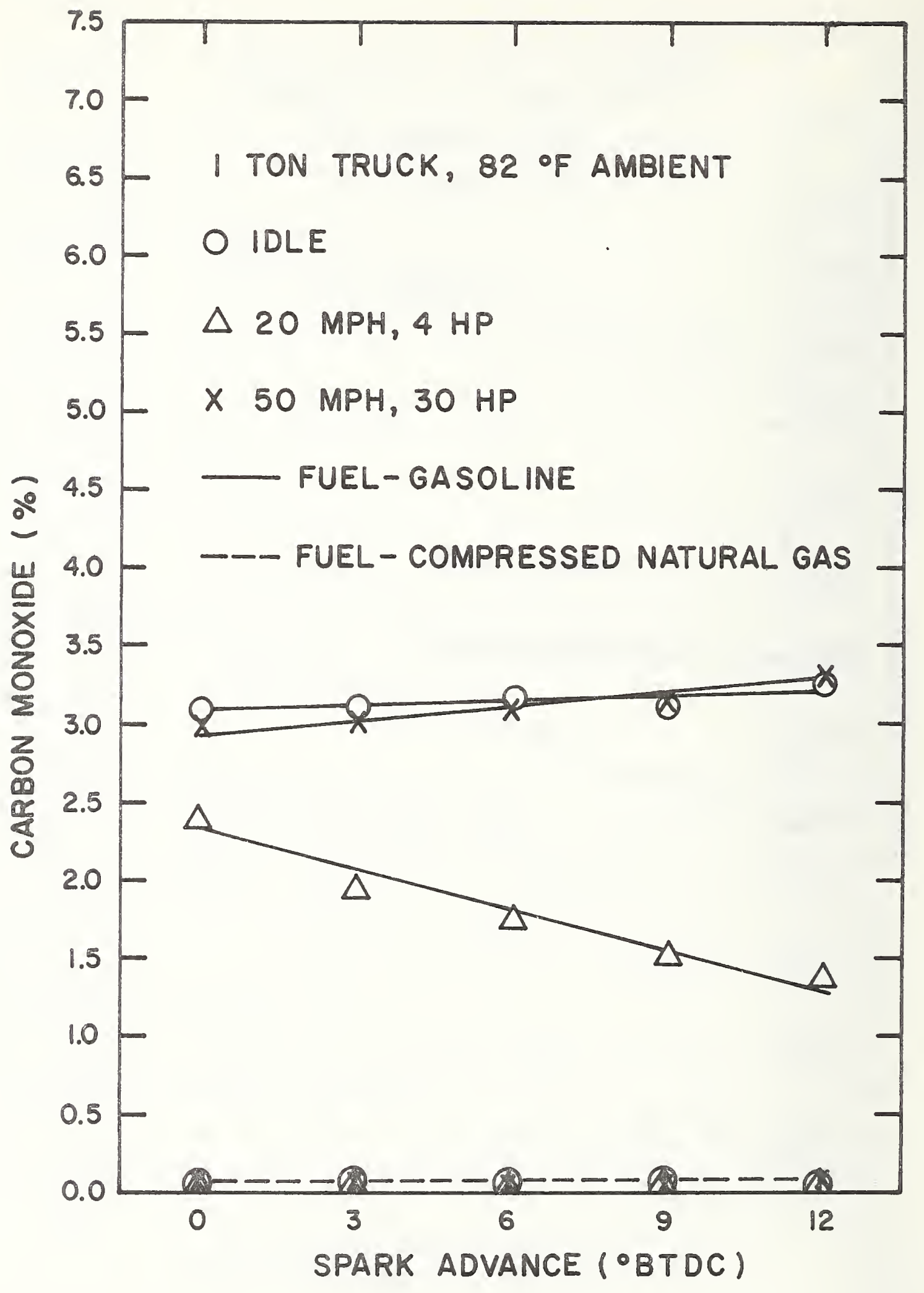

Figure 117 Carbon Monoxide Versus Spark Advance for a 1 Ton Truck Using CNG 


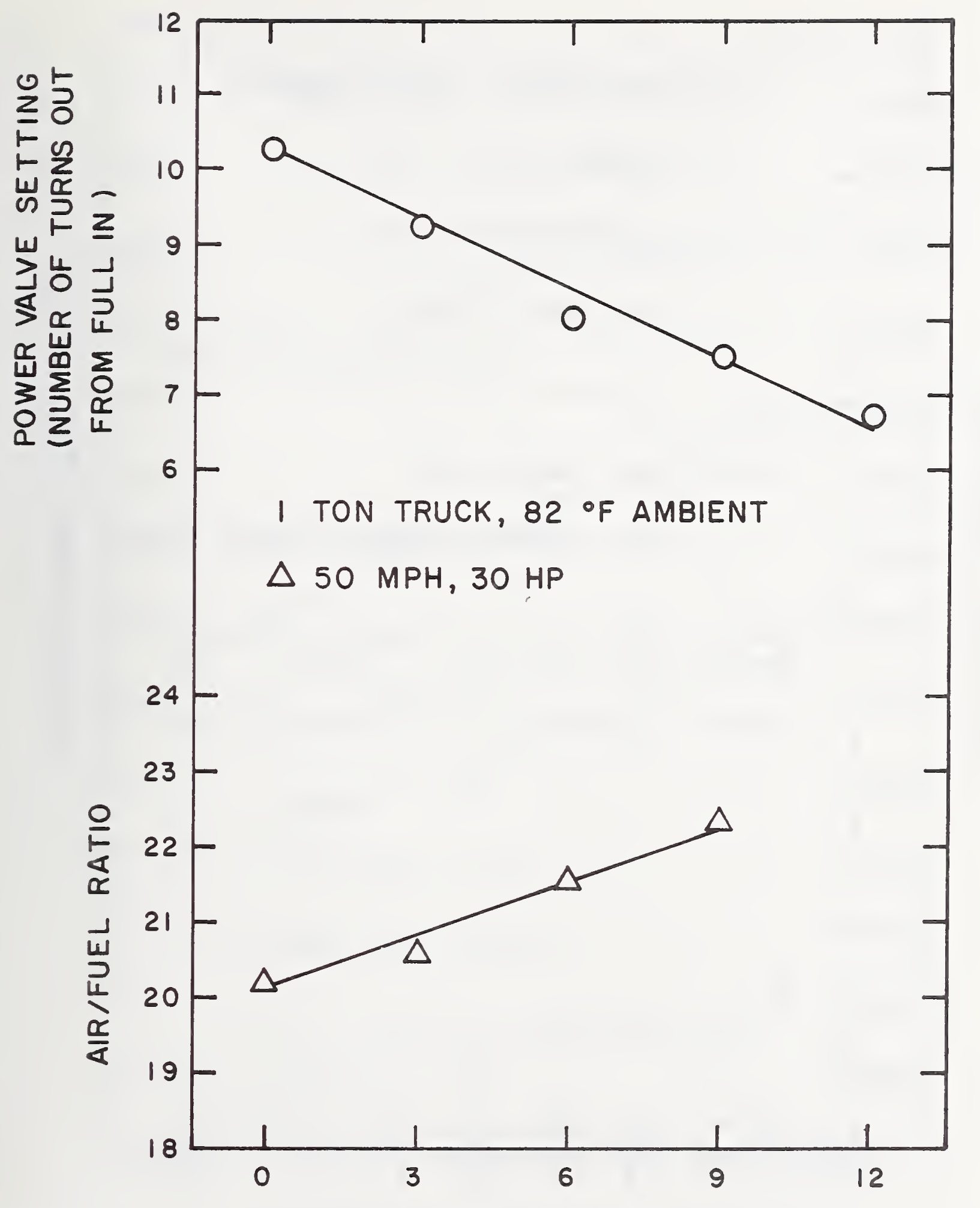

SPARK ADVANCE $\left({ }^{\circ} B T D C\right)$

Figure 118 Air-Fue 1 Ratio and Power Valve Setting Versus Spark Advance for a 1 Ton Truck Using CNG 


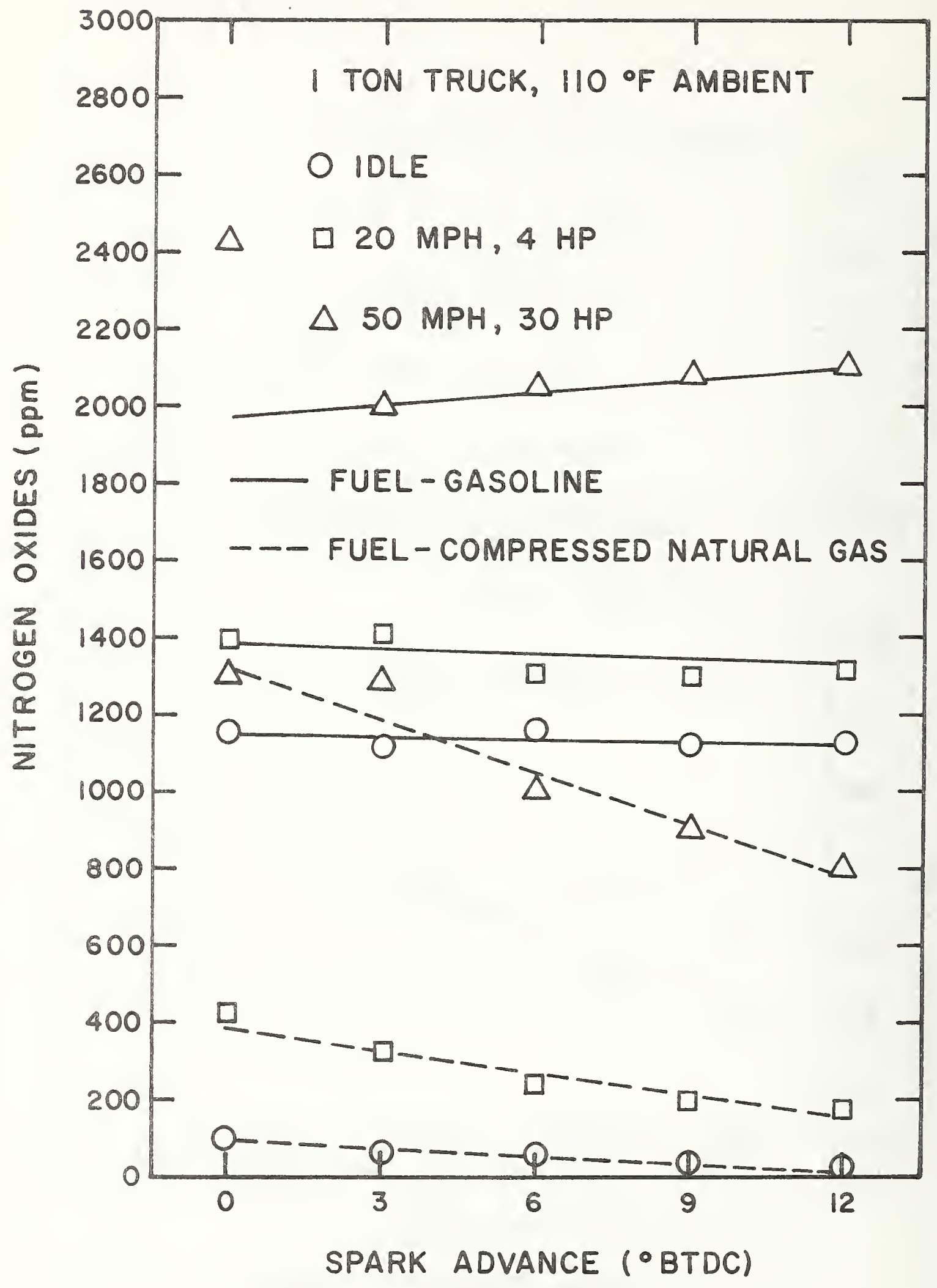

Figure 119 Nitrogen Oxides Versus Spark Advance for a 1 Ton Truck Using CNG 


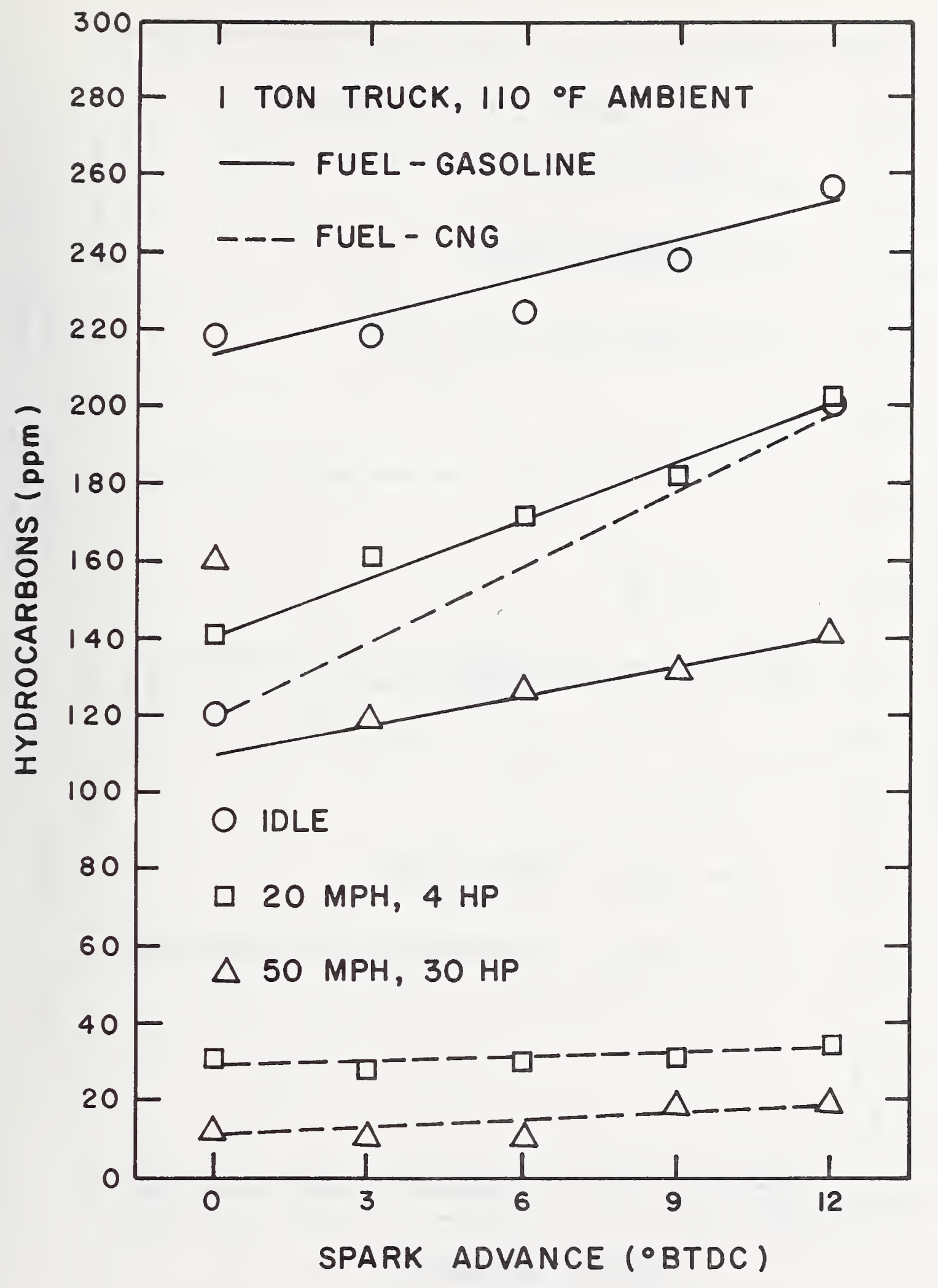

Figure 120 Hydrocarbons Versus Spark Advance for a 1 Ton Truck Using CNG 


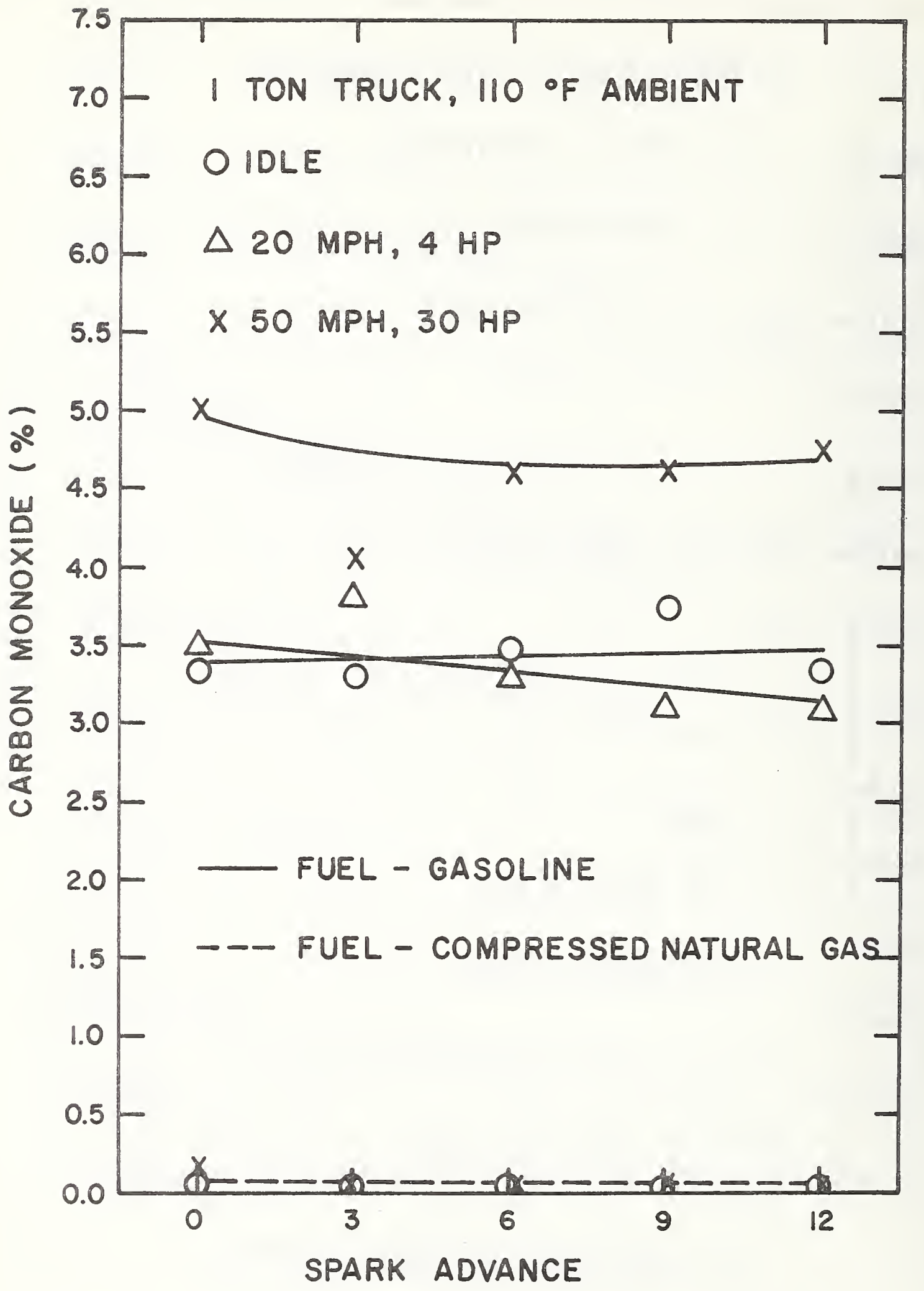

Figure 121 Carbon Monoxide Versus Spark Advance for a 1 Ton Truck Using CNG 


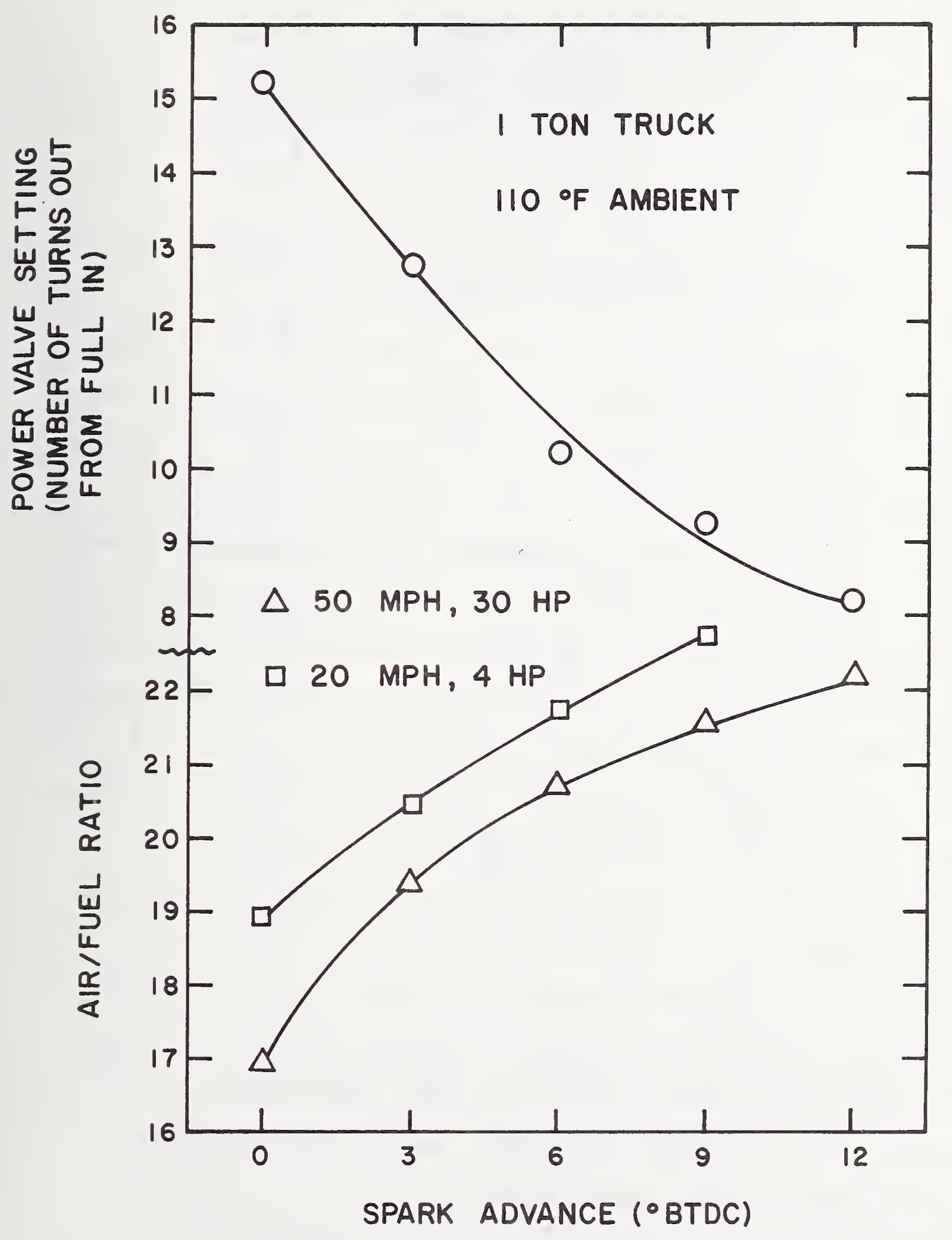

Figure 122 Air-Fuel Ratio and Power Valve Setting Versus Spark Advance for a 1 Ton Truck Using CNG 
BTDC was reached the mixture was so lean that low speed runing conditions were not always acceptable.

Figures 114,118 , and 122 are respective test correlations between the A/F ratio setting for each spark advance and the power valve setting.

5.2.2 Air-Fuel Ratio as the Independent Variable

Figures 123 through 126 show the results of tests conducted to determine the maximum power capability of the vehicle (and amount of associated pollutants) operating on CNG at a moderate temperature. The way in which $\mathrm{NO}_{\mathrm{x}}, \mathrm{HC}$, and CO varied with air-fuel ratio was exactly the same as was noted and discussed on the first vehicle. The change in spark advance from $0^{\circ}$ before top-dead-center to $12^{\circ}$ before top-dead-center produced a significant increase in road horsepower with a corresponding

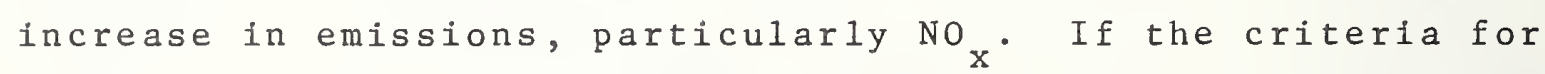
performance were 30 horsepower at 50 miles per hour, the curves show that it would be possible to maintain No ${ }_{x}$ below some arbitrary level, say $1000 \mathrm{ppm}$, in various ways. For example, with a spark advance of $12^{\circ}$ and an $A / F$ ratio > 21.5 (see Figure 123) or with an advance of $0^{\circ}$ and a leaner A/F ratio than 19, the NO would be below 1000 ppm. Checking the other emissions would suggest that of the two alternatives less spark advance and richer mixture would be more advantageous in that there would be less hydrocarbons. 


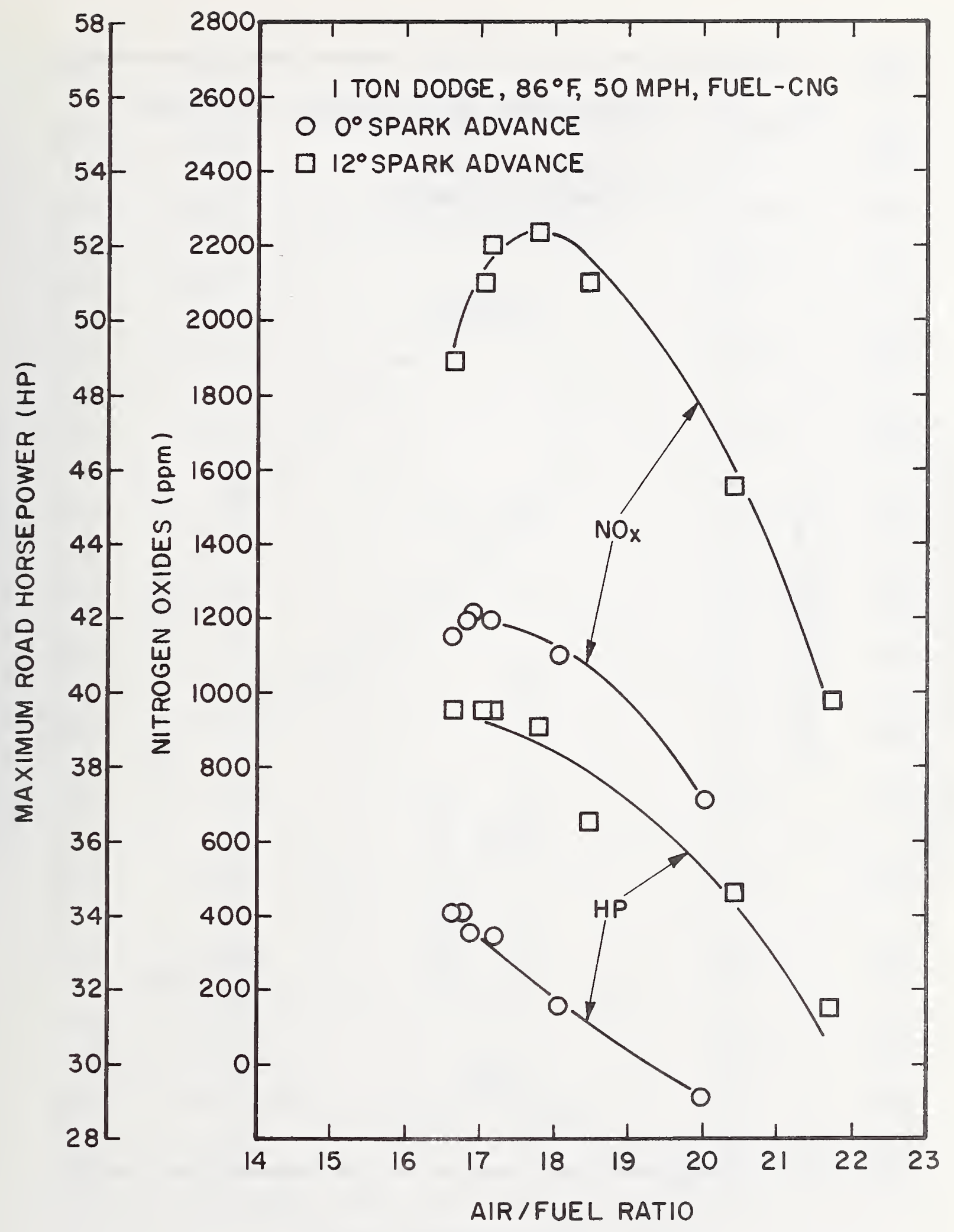

Figure 123 Maximum Horsepower and Nitrogen Oxides Versus AirFue 1 Ratio for a 1 Ton Truck Using CNG and Operating at Full Throttle 


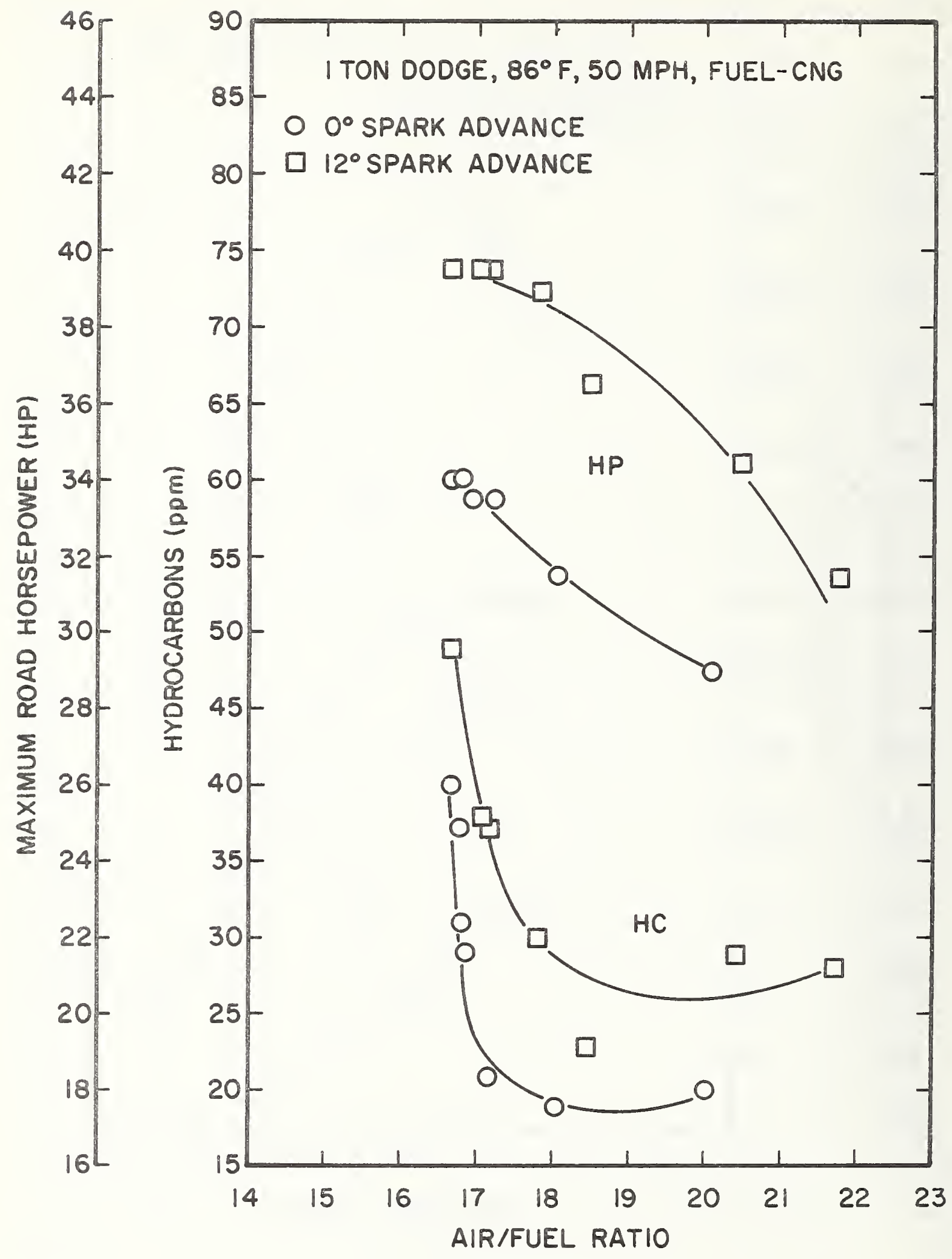

Figure 124 Maximum Horseposer and Hydrocarbons Versus Air-Fue 1 Ratio for a 1 Ton Truck Using CNG and Operating at Ful1 Throttle 


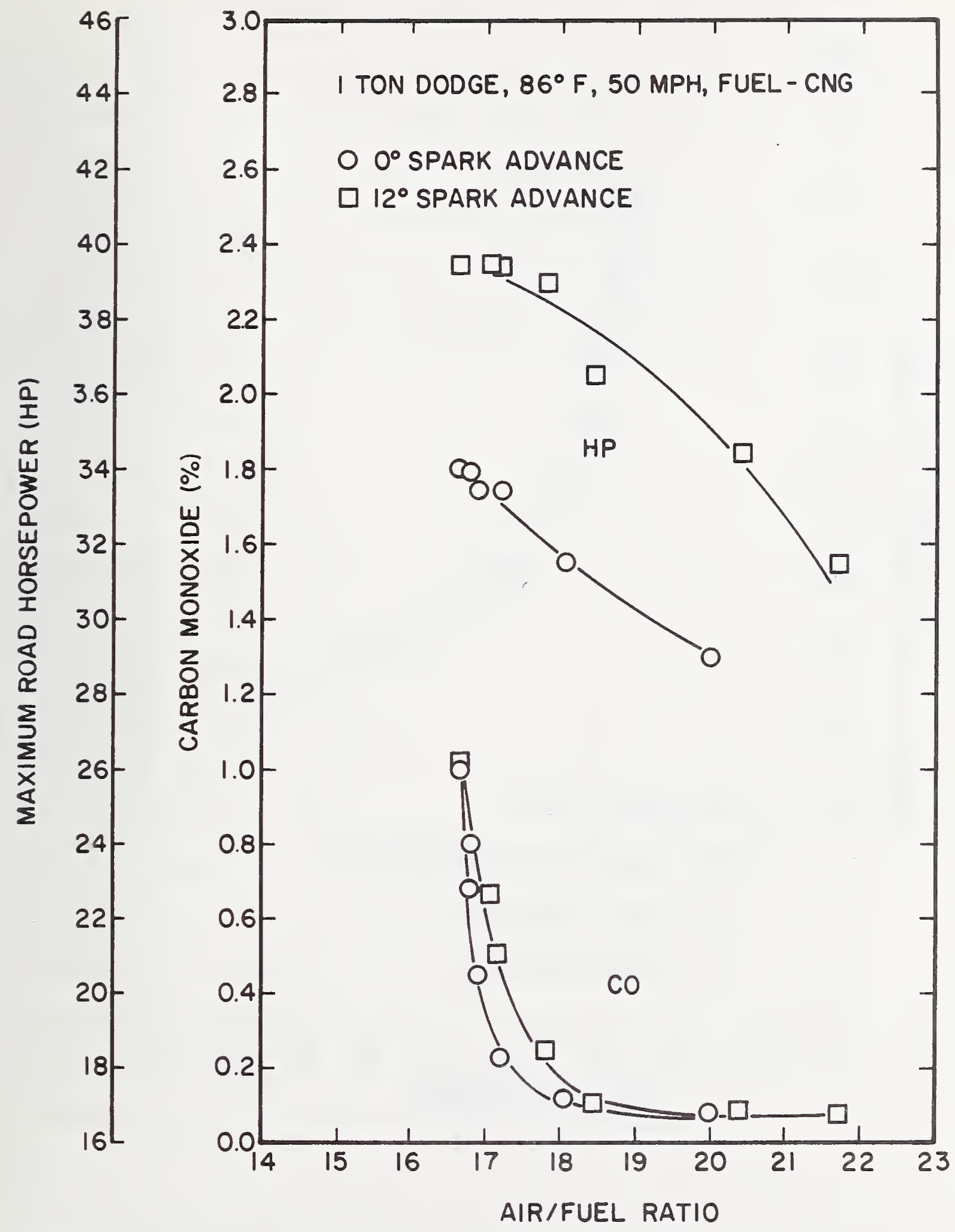

Figure 125 Maximum Horsepower and Carbon Monoxide Versus AirFuel Ratio for a 1 Ton Truck Using CNG and operating at Full Throttle 


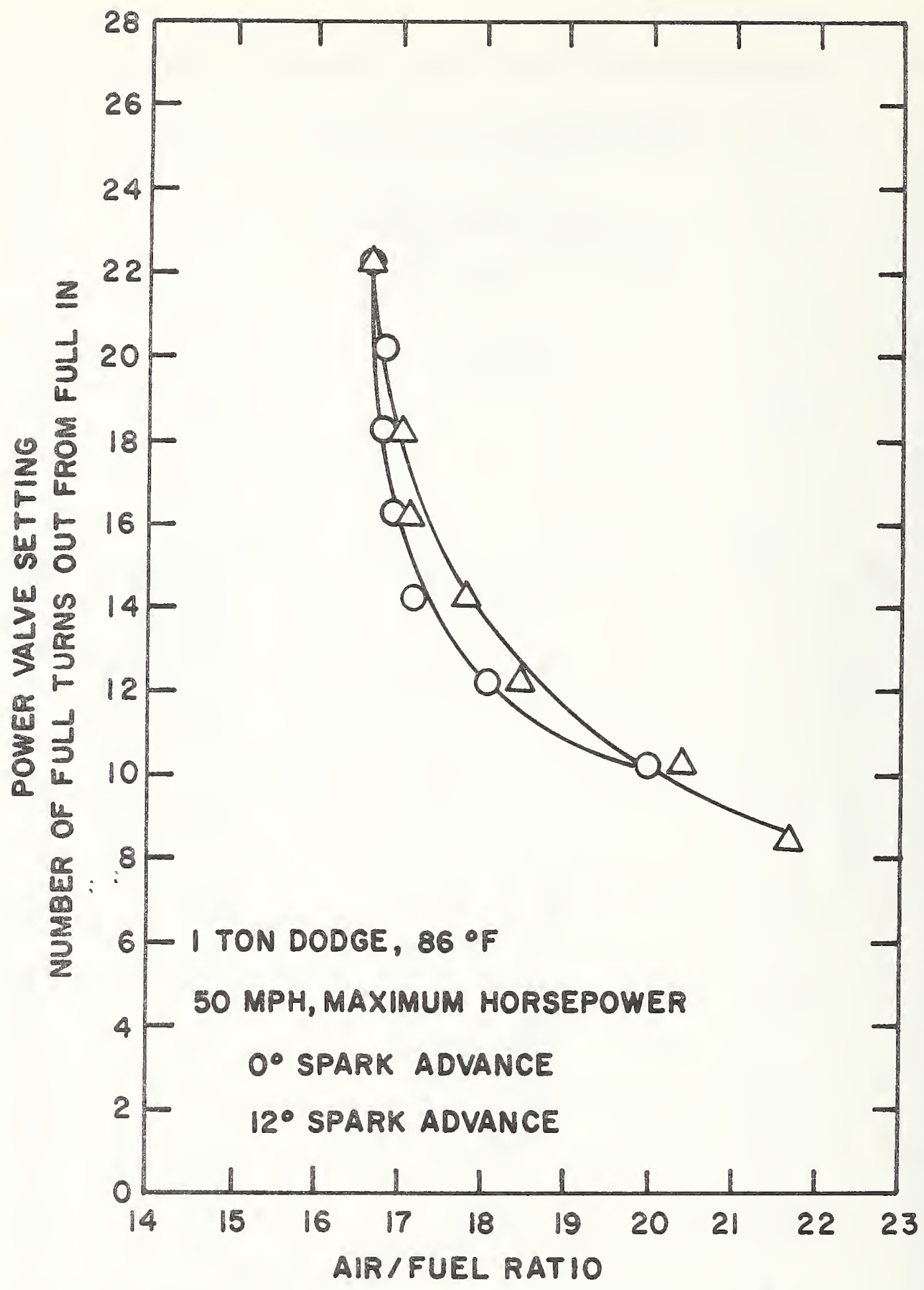

Figure 126 Power Valve Setting Versus Air-Fuel Ratio for a 1 Ton Truck Using CNG and operating at Full Throttle 
For this natural gas system, it has already been mentioned that a power valve in the form of a simple screw line obstruction, was used to vary the gas flow rate after the last stage pressure regulator. The results of a correlation between the valve settings and the A/F ratio are presented in Figure 126. An inspection of the mechanism, however, indicated that it was not designed for precise repeatability in setting and it is questionable whether other similar valves using the same settings would yield these same results.

It was pointed out that the operation of the CNG fuel system for the $1 / 2$ ton truck was such that for a given second stage regulator pressure and tweeker setting the air-fuel ratio became leaner as the vehicle was run at higher speeds and loads. The same behavior was noted for the LPG fuel system when a lean setting (2) was chosen. This is advantageous since the $\mathrm{NO}_{\mathrm{x}}$ concentration would decrease significantly with the simultaneous leaning process. There appear to be indications that the fuel system for this second truck operates in the opposite way. From Figure 107, it can be seen that for a running condition of $20 \mathrm{mph} / 4 \mathrm{hp}$, a power valve setting of $121 / 4$ turns resulted in an air-fuel ratio of approximately 21 . From Figure 126, the same power valve setting for a larger load and speed (50 mph/maximum horsepower) gave an air-fuel ratio of approximately 18. Such a response is compatible with the way in which ordinary gasoline carburetors behave; however, it is not the most desirable operation from the standpoint of minimum $\mathrm{NO}_{\mathrm{x}}$ emissions. 
Figures 127, 128 , and 129 are emission plots for tests run at ambient conditions of $14^{\circ} \mathrm{F}$ and $112^{\circ} \mathrm{F}$. A constant speed of $20 \mathrm{mph}$ was maintained and the dynamometer horsepower recorded was a maximum since the throttle was full open. Under these conditions the emissions were greater for the low temperature condition but the available horsepower was also greater. This is logical since a constant volume engine would receive a greater mass flow of mixture under the more dense air conditions of the cooler environment. The spark advance of $9^{\circ}$ BTDC was somewhat arbitrarily selected because it was felt that it is near the optimum setting. There is no technical reason to indicate that the ambient temperature effect would have been significantly different at another advance setting.

Figure 130 is again a correlation between the power valve setting and the air-fuel ratio. The results indicate that this fuel system responded to give a leaner mixture for the same power valve setting as the ambient temperature was decreased.

\subsection{Cold-Start Tests}

The start tests for this vehicle were conducted along the same general lines as for the $1 / 2$ ton truck. After allowing the truck to soak at a $0^{\circ} \mathrm{F}$ chamber for only 3 hours, the tests were started using $C N G$ as the fuel and employing the standard ignition. Regardless of the spark setting and whether the throttle was used or not, no start could be obtained. When the CDI system was used, starting was successful in 12 seconds at 


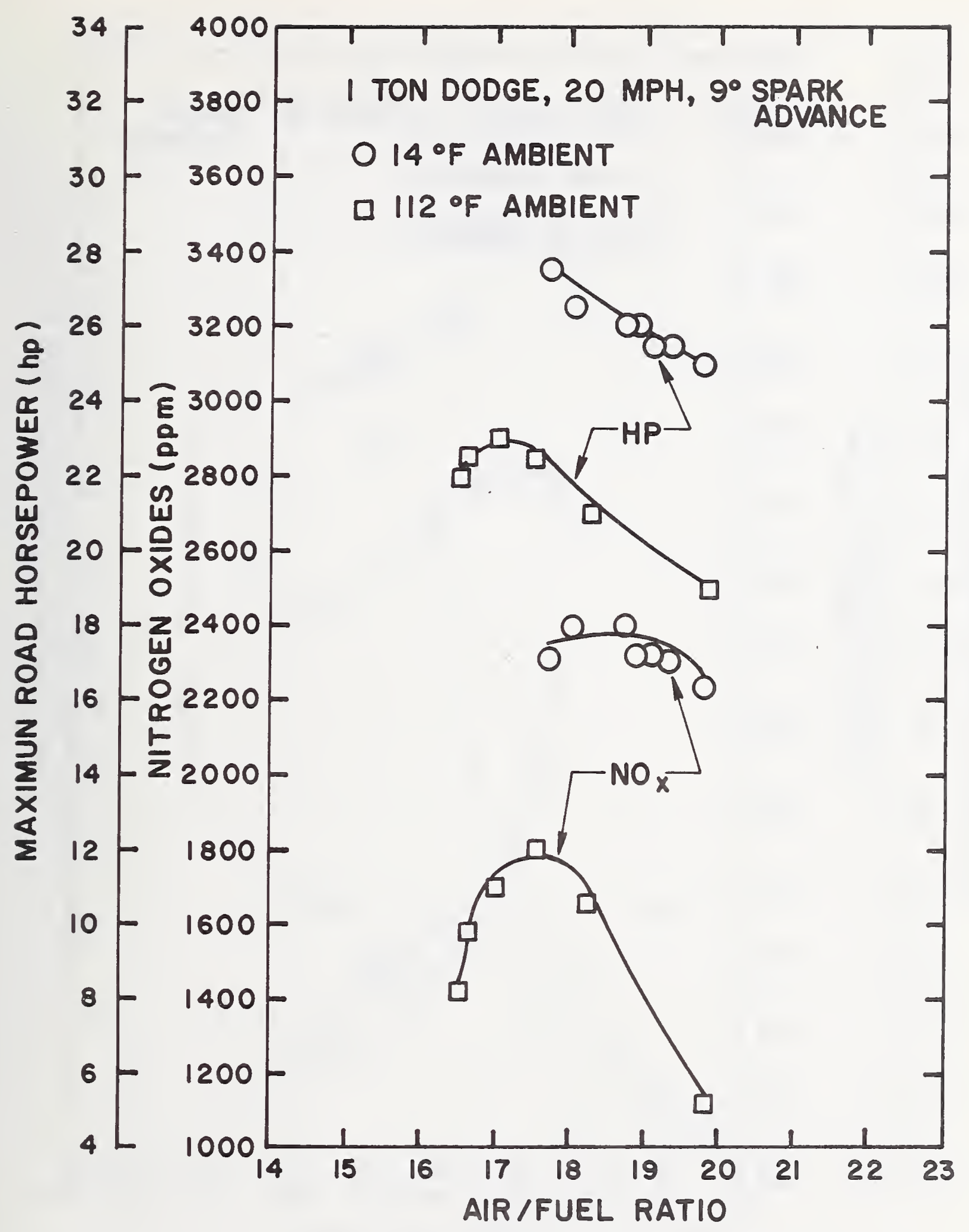

Figure 127 Maximum Horsepower and Nitrogen Oxides Versus Air-Fuel Ratio for a 1 Ton Truck Using CNG and Operating at Full Throttle 


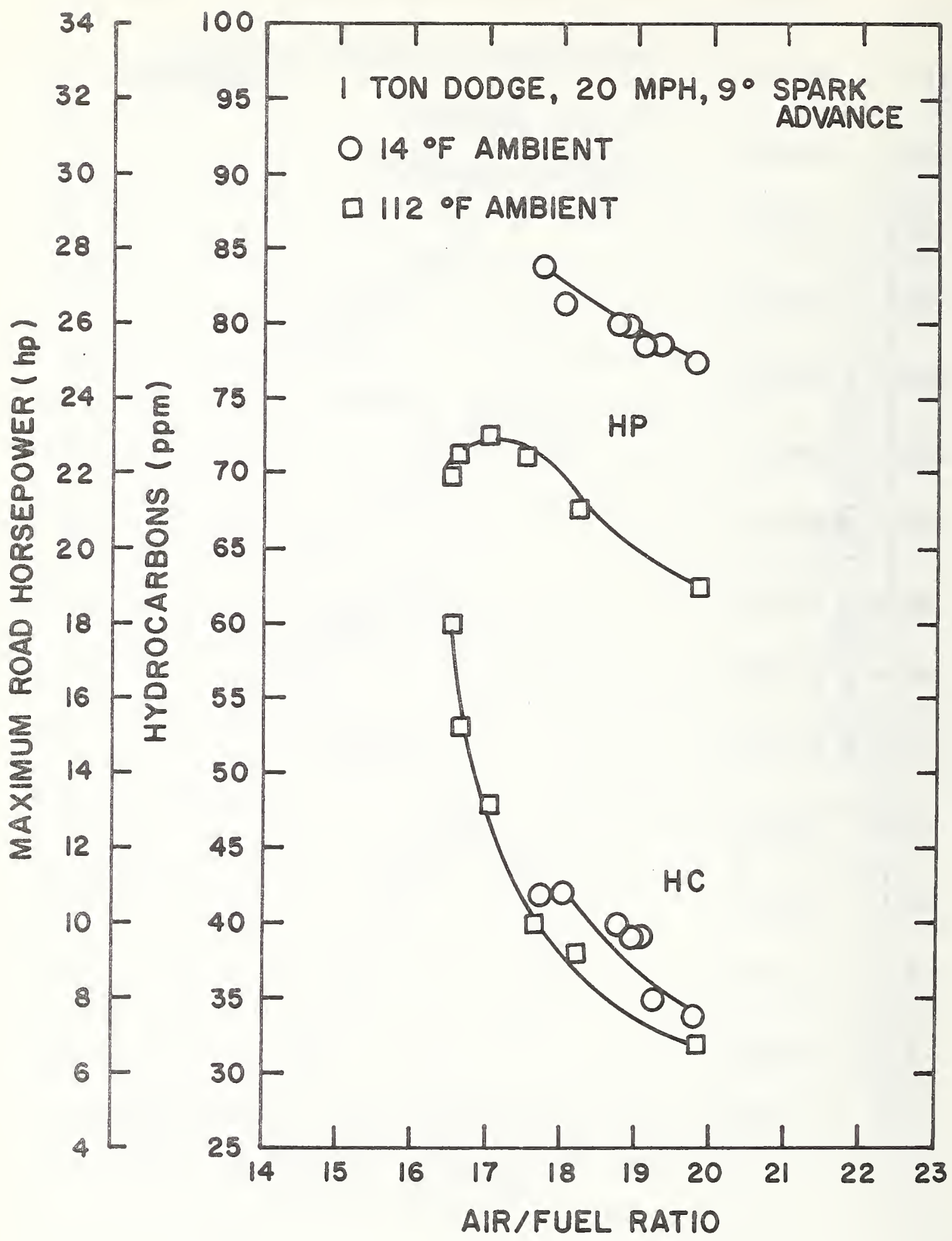

Figure 128 Maximum Horsepower and Hydrocarbons Versus AirFuel Ratio for a 1 Ton Truck Using CNG and operating at Full Throttle 


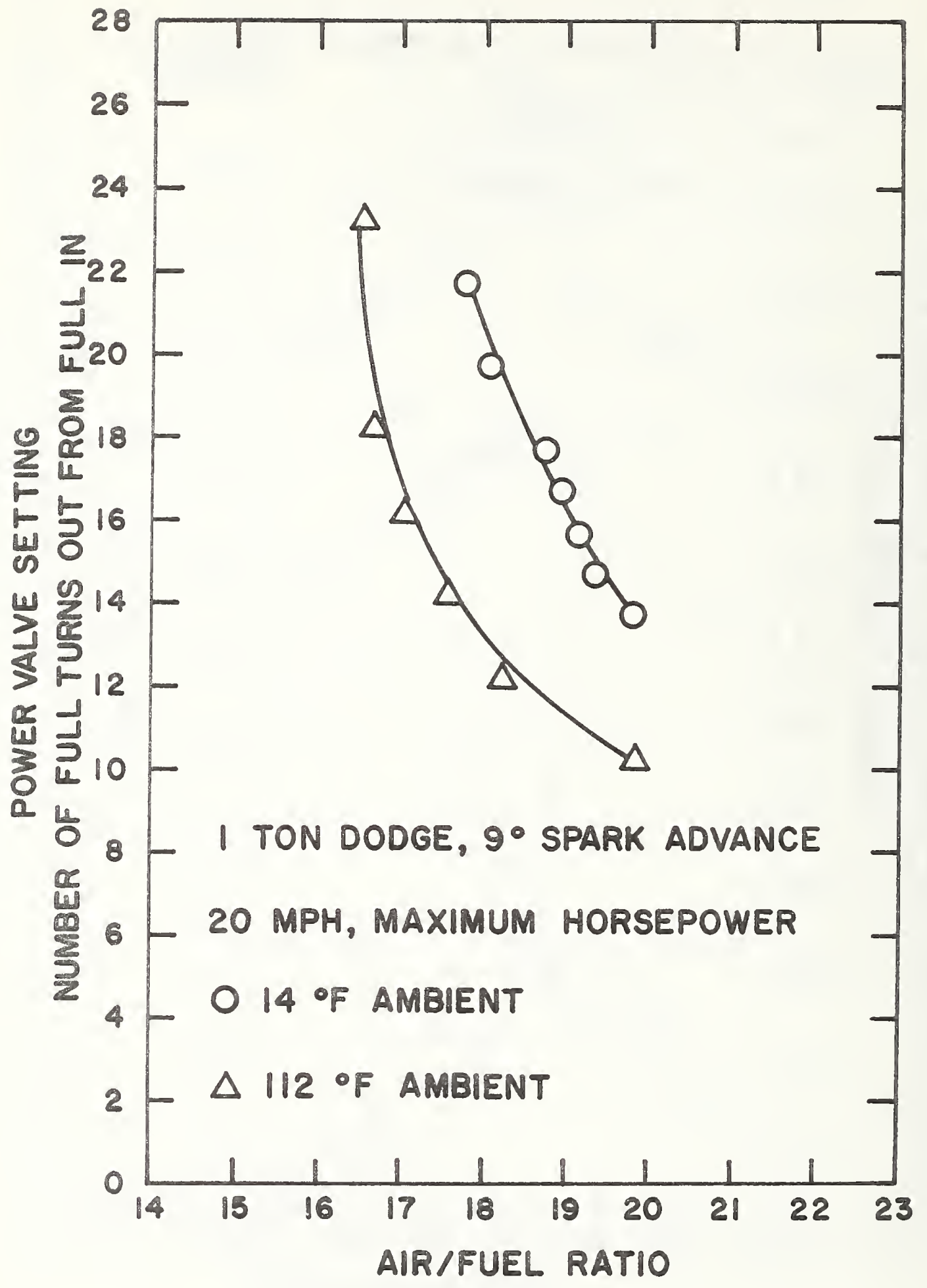

Figure 130 Power Valve Setting Versus Air-Fuel Ratio for a 1 Ton Truck Using CNG and Operating at Full Throttle 
$0^{\circ}$ spark advance when the throttle was used. However, when the standard ignition was tried again, starting was also successful. Gasoline start tests were then begun. After trying both ignition systems and with and without use of the throttle, starting could only be obtained by entering the chamber, removing the air cleaner, and choking the carburetor by hand.

Because the soaking time was so short in the tests discussed above, it was decided to allow the vehicle to remain at $0^{\circ} \mathrm{F}$ overnight and repeat the tests. After 21 hours at this low temperature, the vehicle could not be started under any circumstances (regardless of fuel, ignition system, spark advance and use of choke and throttle). It was felt that the starting difficulties lie with the engine rather than the ignition systems. 
The following specific conclusions are made concerning running the $1 / 2$ ton vehicle on compressed natural gas:

1. Idling was never a problem since the tweeker could always be adjusted to give a good idle regardless of temperature or idle gas pressure $\left(0-110^{\circ} \mathrm{F}\right)$.

2. An idle gas pressure setting of 3 in. H2O or less was necessary to keep the $\mathrm{NO}_{\mathrm{X}}$ below $1000 \mathrm{ppm}$ while the vehicle was running at $50 \mathrm{mph} / 30 \mathrm{hp}\left(0-110^{\circ} \mathrm{F}\right)$.

3. The idle gas pressure had to be kept above 1.5 in. $\mathrm{H}_{2} \mathrm{O}$ to insure $30 \mathrm{hp}$ at $50 \mathrm{mph}\left(0-110^{\circ} \mathrm{F}\right)$.

4. The optimum spark advance for good performance and low emission was $6^{\circ}$ BTDC $\left(0-110^{\circ} \mathrm{F}\right)$.

The following specific conclusions can be made concerning running the $1 / 2$ ton vehicle on propane:

1. Idling was never a problem with the vehicle regardless of temperature $\left(0-110^{\circ} \mathrm{F}\right)$.

2. The optimum power valve setting for minimum pollutants and acceptable power was position 2 .

3. The optimum idling spark setting for minimum pollutants and acceptable power was $0^{\circ}$ BTDC.

The following conclusions can be made concerning running the 1 ton vehicle on compressed natural gas:

1. Idling was generally poor regardless of power valve setting and resulting air-fuel ratio in the region of a lean mixture $\left(0-110^{\circ} \mathrm{F}\right)$.

2. To insure acceptable running the power valve had to be adjusted so that the air-fuel ratio was no leaner than 21 while producing 30 horsepower at $50 \mathrm{mph}\left(0-110^{\circ} \mathrm{F}\right)$.

3. The optimum spark advance for good performance and low emissions was $6^{\circ}$ BTDC $\left(0-110^{\circ} \mathrm{F}\right)$. 
The various tables contained in this report reflect the considerable reduction achieved in emissions throughout the load, speed, ambient conditions and spark timing range, of engines operated on natural gas or propane as opposed to gasoline. In most cases, the inherent difference in fuel composition results in considerably cleaner combustion when operating under load and speed conditions required by typical Postal Service delivery vehicles.

As a "bench-mark", comparing test results to present data and future Federal emission limits, Table 2 indicates the requirements and results of the $1 / 2$ ton vehicle ( 3940 pounds) and the 1 ton vehicle ( 4700 pounds). The range of test result data shown in the table are for carburetor and spark settings that would be chosen when using the respective systems. It must be emphasized that the test data reflects performance curves and portable gas analysis instrumentation and has minimal relationship to the Federal test requirements which are based upon a critically controlled operating cycle with constant volume sampling of emissions by selected laboratory instrumentation. Further, the vehicles under test were both 1969 models, with minimal emission control equipment designed to satisfy requirements only for that year. 
TABLE 5

GENERAL COMPARISON OF EMISSIONS

\begin{tabular}{|c|c|c|c|}
\hline Vehicles & $\begin{array}{c}1973-5 \\
(3.1 \mathrm{gm} / \mathrm{mt})\end{array}$ & $\begin{array}{c}\mathrm{NO}_{\mathrm{x}} \\
1976 \\
(.40 \mathrm{gm} / \mathrm{mi})\end{array}$ & $\begin{array}{c}\text { Test Results } \\
\text { (Range) }\end{array}$ \\
\hline $\begin{array}{l}\text { 1/2 Ton Vehicle } \\
\text { ( } 3940 \text { Ibs) } \\
\text { Gasoline }\end{array}$ & 771 ppm & $102 \mathrm{ppm}$ & $300-2400 \mathrm{ppm}$ \\
\hline $\begin{array}{l}1 / 2 \text { Ton Vehicle } \\
(3940 \text { 1bs) CNG }\end{array}$ & $771 \mathrm{ppm}$ & $102 \mathrm{ppm}$ & $100-300$ ppm \\
\hline $\begin{array}{l}1 / 2 \text { Ton Vehicle } \\
(3940 \text { 1bs) LPG }\end{array}$ & $771 \mathrm{ppm}$ & 102 ppm & $100-500 \mathrm{ppm}$ \\
\hline $\begin{array}{l}1 \text { Ton Vehicle } \\
\text { ( } 4700 \text { 1bs) } \\
\text { Gasoline }\end{array}$ & 718 ppm & $95 \mathrm{ppm}$ & $700-2300 \mathrm{ppm}$ \\
\hline $\begin{array}{l}1 \text { Ton Vehicle } \\
(4700 \text { lbs) CNG }\end{array}$ & 718 ppm & $95 \mathrm{ppm}$ & $75-1000 \mathrm{ppm}$ \\
\hline
\end{tabular}


TABLE 5 ( $\left.\operatorname{con}^{\prime} d\right)$

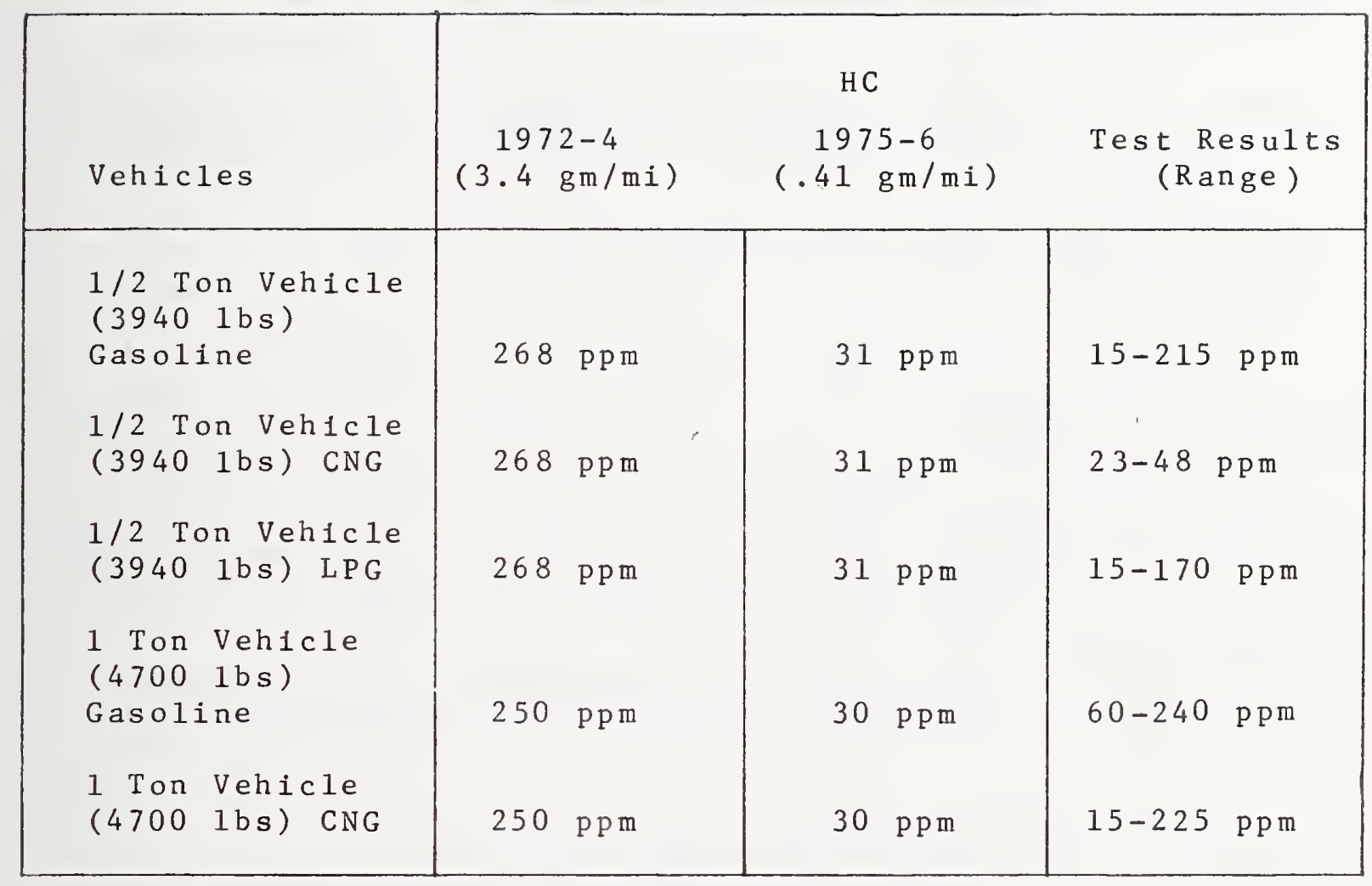


TABLE 5 ( $\left.\operatorname{cont}^{\prime} d\right)$

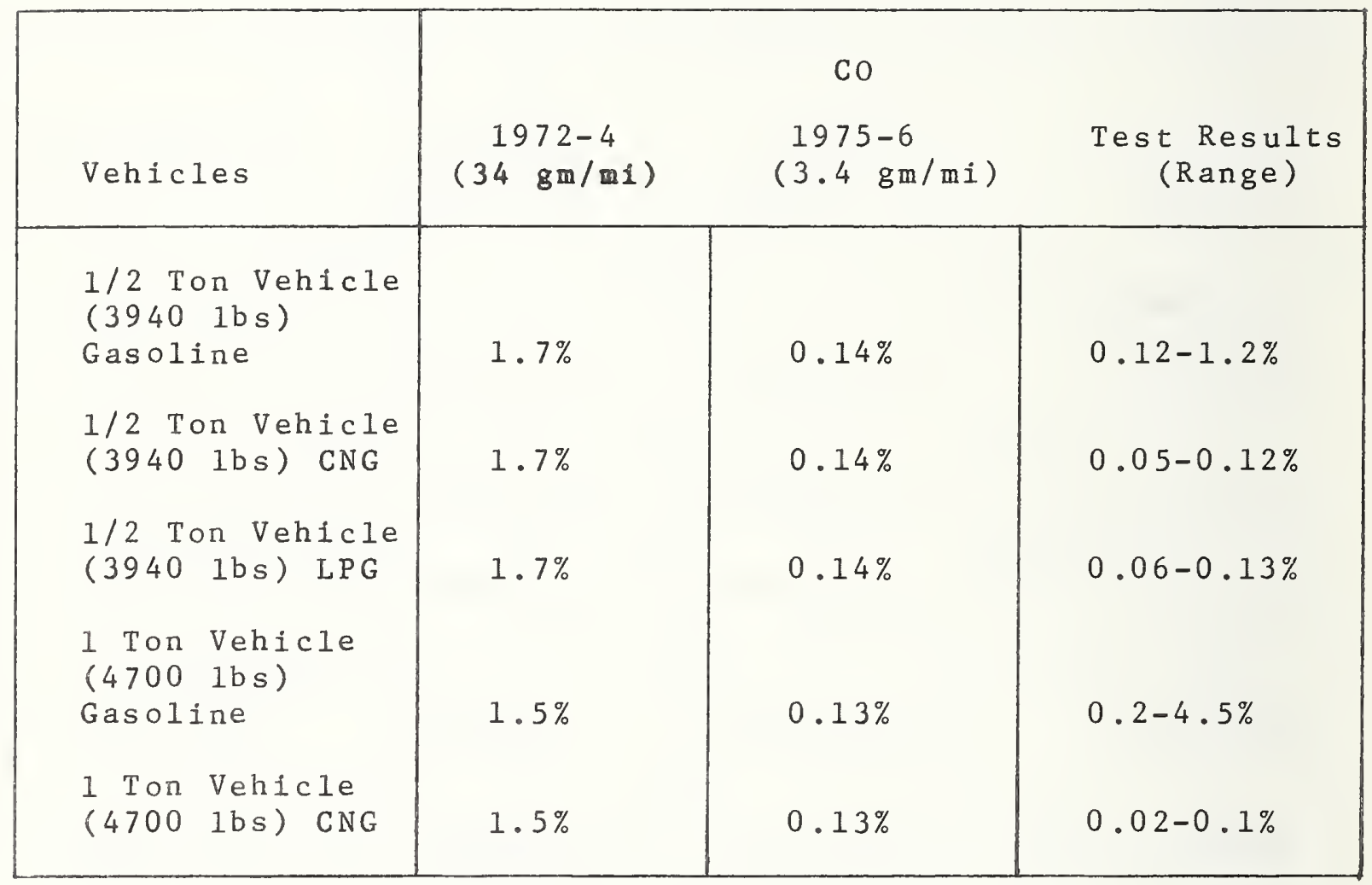


1. Heywood, John B., James C. Keck, et. al., "Quantify Auto Pollution Processes", Mechanical Engineering, pg. 38,

February 1973 .

2. Federal Register, Vol. 36, No. 128, Part II, July 2, 1971.

3. Conta, L. D., "I-C Engine and the Environment", Mechanical Engineering, pg. 29, July 1972 .

4. Caplan, J. D. "Smog Chemistry Points the Way to Rational Vehicle Emission Control", SAE Paper 650641, August 16-19, 1965.

5. "Search", by.. Technical Information Center, General Motors Research Laboratory, May/June, 1966.

6. "Motor Vehicles, Air Pollution, and Health", Surgeon General's Report to the U. S. Congress, June 1962.

7. Eltigne, Lamont, "Fuel-Air Ratios and Distribution from Exhaust Gas Composition", SAE Paper 680114, 1968.

8. Personal communication with sue A. Gendernalik, Automotive Research, Ethyl Corporation, Ferndale, Michigan .

9. Amann, C. A., "Thermodynamics and Smog", presented at the American Society for Engineering Education Annual Meeting, Annapolis, Maryland, June 21-24, 1971 .

10. Bolt, J.A., and D. E. Cole, Low Emission Power Plant Systems: A Technical Evaluation, University of Michigan Short Course, Ann Arbor, Michigan, August 7-11, 1972.

11. Bulpitt, W. S., A Comparative Study of the Exhaust Emissions of a Wankel Engine Using Gasoline and Natural Gas as Fuels, M. S. Thesis, Georgia Institute of Technology, Atlanta, Georgia, April, 1972 . 
8. Acknowledgements

The authors would like to acknowledge the very capable assistance given in the laboratory throughout the duration of this study by Mr. John Grimes, Mr. David Ward, and Mr. Boyd Shomaker of NBS and Mr. Bud Windell of the U. S. Postal Service. Their comments and suggestions were invaluable in determining appropriate testing procedures and diagnosing experimental problems as they occurred. 
NBS.114A (REV. 7.73)

\begin{tabular}{|c|c|c|c|}
\hline $\begin{array}{c}\text { U.S. DEPT. OF COMM. } \\
\text { BIBLIOGRAPHIC DATA } \\
\text { SHEET }\end{array}$ & $\begin{array}{l}\text { 1. PUBLICATION OR REPORT NO. } \\
\text { NBSIR } 74-460\end{array}$ & $\begin{array}{l}\text { 2. Gov't Accession } \\
\text { No. }\end{array}$ & 3. Recipient's Accession No. \\
\hline \multirow{2}{*}{\multicolumn{3}{|c|}{$\begin{array}{l}\text { 4. TITLE AND SUBTITLE } \\
\text { Comparison of power Output and Exhaust Pollutants of Two } \\
\text { Postal Service Vehicles Operated on Three Hydrocarbon Fuels }\end{array}$}} & 5. Publication Date \\
\hline & & & 6. Performing Organizarion Code \\
\hline \multirow{3}{*}{\multicolumn{3}{|c|}{$\begin{array}{l}\text { 7. AUTHOR(S) } \\
\text { J.E. HiT and D.A. Didion } \\
\text { 9. PERFORMING ORGANIZATION NAME AND ADDRESS } \\
\text { NATIONAL BUREAU OF STANDARDS } \\
\text { DEPARTMENT OF COMMERCE } \\
\text { WASHINGTON, D.C. } 20234\end{array}$}} & $\begin{array}{l}\text { 8. Performing Organ. Report No. } \\
\text { NBSIR 74-460 }\end{array}$ \\
\hline & & & $\begin{array}{l}\text { 10. Project/Task/Work Unit No. } \\
4624747\end{array}$ \\
\hline & & & $\begin{array}{c}\text { 11. Contract/Grant No. } \\
-\end{array}$ \\
\hline \multirow{2}{*}{\multicolumn{3}{|c|}{$\begin{array}{l}\text { 12. Sponsoring Organization Name and Complete Address (Street, City, State, ZIP) } \\
\text { U. S. Posta T Service } \\
\text { Bureau of Research and Engineering } \\
\text { Washington, D. C. } 20260\end{array}$}} & $\begin{array}{l}\text { 13. Type of Report \& Period } \\
\text { Covered } \\
\text { Fina } 1\end{array}$ \\
\hline & & & 14. Sponsoring Agency Code \\
\hline
\end{tabular}

15. SUPPLEMENTARY NOTES

16. ABSTRACT (A 200-word or less factual summary of most significant information. If document includes a significant bibliography or literature survey, mention it here.)

One possible solution for the reduction of pollutants from internal combustion engines is the use of gaseous fuels such as natural gas or propane. The best application for the use of these fuels appears to be with fleet operators. The federal government operates between 300,000 and 400,000 vehicles which makes it an excellent candidate for using them. This paper describes a laboratory investtigation in which the power output and pollutant levels of two Postal Service vehicles equipped with dual-fuel systems, were determined at simulated road conditions in an environmental chamber at temperatures from $0^{\circ} \mathrm{F}$ to $100^{\circ} \mathrm{F}$.

17. KEY WORDS (six to twelve entries; alphabetical order; capitalize only the first letter of the first key word unless a proper name; separated by semicolons)

Air pollution; compressed natural gas engine; dual fuel vehicles; propane engine; vehicle emissions

18. AVAILABILITY $\square$ Unlimited

X For Official Distribution. Do Not Release to NTIS

Order From Sup. of Doc., U.S. Government Printing Office Washington, D.C. 20402, SD Cat. No. C.13

Order From Narional Technical Information Service (NTIS) Springfield, Virginiz 22151

\begin{tabular}{|l|l|}
\hline $\begin{array}{l}\text { 19. SECURITY CLASS } \\
\text { (THIS REPURT) }\end{array}$ & 21. NO. OF PAGES \\
UNCL ASSIFIED & \\
\hline $\begin{array}{l}\text { 20. SECURITY CLASS } \\
\text { (THIS PAGE) } \\
\text { UNCLASSIFIED }\end{array}$ & 22. Price \\
\hline
\end{tabular}




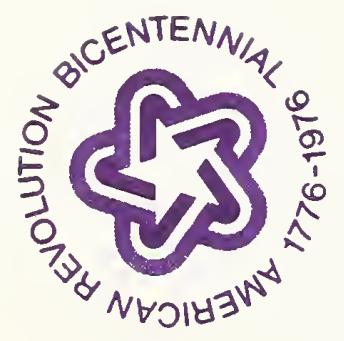

